\title{
The Transatlantic RifT IN \\ Genetically Modified Food Policy
}

Thesis

presented to the Faculty of Arts

of

the University of Zurich

for the degree of Doctor of Philosophy

by

Celina Ramjoué

of Germany

Accepted in the summer semester 2006 on the recommendation of Prof. Dr. Daniel Kübler and Prof. Dr. Frédéric Varone 
The Transatlantic Rift in Genetically Modified Food Policy

\section{Table of Contents}

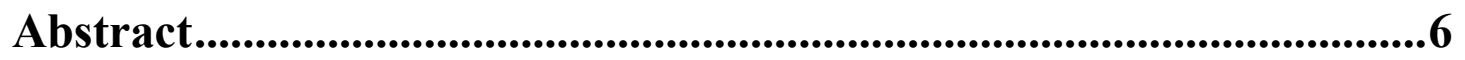

Acknowledgments .........................................................................................

Acronyms and Abbreviations ................................................................8

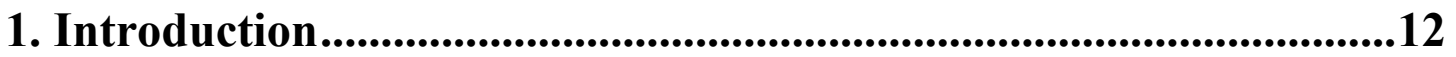

1.1 Research question $\quad 12$

$\begin{array}{ll}1.2 \text { Time span covered and definitions } & 17\end{array}$

1.3 The transatlantic rift in GM food policy: literature review 20

$\begin{array}{ll}\text { Empirical fields } & 20\end{array}$

Theoretical approaches 23

Hypotheses, propositions, results 25

$\begin{array}{ll}1.4 \text { Project relevance } & 27\end{array}$

Empirical relevance $\quad 27$

$\begin{array}{ll}\text { Theoretical relevance } & 28\end{array}$

Practical relevance 28

1.5 Dissertation overview 29

2. GM Food in the US and the EU: Overview.......................................30

2.1 Overview of GM foods and crops 30

$\begin{array}{ll}2.2 \text { The pros and cons of agricultural biotechnology } & 37\end{array}$

$2.3 \mathrm{GM}$ food and its regulation in the US and the EU: chronological overview $\quad 40$

United States $\quad 40$

European Union 47

3. GM Food Policy: A Transatlantic Comparison..................................58

3.1 Regulatory frameworks $\quad 59$

Explicit guiding principles: product versus process $\quad 59$

Responsible institutions, regulatory frameworks 61

3.2 Regulating field tests $\quad 66$

APHIS: permits and notifications $\quad 67$

EU: Part B notification $\quad 68$

Comparing US and EU field trial regulations and their outputs 70

3.3 Regulating commercialization $\quad 72$

APHIS: nonregulated status $\quad 73$

EPA: PIP registration and tolerance level exemption 73

FDA: voluntary consultation and no labeling rules $\quad 74$

EU: Part C notification and/or 1829/2003 procedure; strict labeling rules $\quad 79$

Comparing US and EU regulations for commercialization and their outputs 82

3.4 Conclusion 86 
$\begin{array}{ll}4.1 \text { Theory } & 89\end{array}$

$\begin{array}{ll}\text { Policy process theory } & 90\end{array}$

Comparative historical analysis 93

Science and technology studies 95

$\begin{array}{ll}4.2 \text { Postulates } & 97\end{array}$

$\begin{array}{lr}\text { Causality } & 97\end{array}$

$\begin{array}{lr}\text { Beliefs matter } & 100\end{array}$

$\begin{array}{ll}4.3 \text { Method } & 102\end{array}$

Developing a "medium-range" framework 102

Focused and systematic comparison of two cases 104

$\begin{array}{ll}\text { Data sources } & 108\end{array}$

$\begin{array}{ll}4.4 \text { Analytical framework } & 109\end{array}$

Explanatory variable 1: preceding policies $\quad 109$

Explanatory variable 2: paradigms 112

Explanatory variable 3: actors and actor coalitions 116

$\begin{array}{lr}\text { Putting the variables in context } & 119\end{array}$

\section{Preceding Policies: From rDNA Research to its Applications.....122}

5.1 United States: from caution to confidence 123

From the discovery of the double helix to Asilomar 123

National Institutes of Health Guidelines $\quad 125$

Sociopolitical context: anti-establishment and environmentalist 127

$\begin{array}{ll}\text { Transition into the 1980s } & 131\end{array}$

5.2 Europe and the EC: from guarded support to precaution 134

$\begin{array}{ll}\text { European scientists and rDNA research } & 134\end{array}$

UK Code of Practice and EC Recommendation 136

Bridging the transatlantic science and technology gap 138

Environmentalism and the rise of anti-GMO sentiment 139

$\begin{array}{ll}\text { Putting in place Directive 90/220 } & 142\end{array}$

5.3 Conclusion 144

\section{Paradigms: Uncovering Underlying Beliefs ......................................146}

6.1 Economic competitiveness versus environmental and health protection $\quad 147$

$\begin{array}{ll}\text { US and EU paradigms described } & 147\end{array}$

$\begin{array}{ll}\text { Paradigm manifestations } & 148\end{array}$

Linking competitiveness and protection to agriculture 153

$\begin{array}{ll}\text { 6.2 Sound science versus precautionary principle } & 161\end{array}$

US and EU paradigms described 161

$\begin{array}{ll}\text { Paradigm manifestations } & 162\end{array}$

Linking sound science and the precautionary principle to risks 168

$\begin{array}{lr}\text { Risk-taking and judicial systems } & 173\end{array}$

$\begin{array}{ll}6.3 \text { Conclusion } & 175\end{array}$

7. Actors and Actor Coalitions: Different Levels of Success .............177

7.1 Actors and actor coalitions in the United States 178

$\begin{array}{ll}\text { US actors and actor coalitions in favor of GM food and crops } & 178\end{array}$ 
US actors and actor coalitions against GM foods and crops 186

$\begin{array}{ll}\text { Shock events } & 192\end{array}$

Activity and impact on policy 196

7.2 Actors and actor coalitions in the European Union 201

EU actors and actor coalitions in favor of GM food and crops 201

EU actors and actor coalitions against GM foods and crops 210

$\begin{array}{ll}\text { Shock events } & 215\end{array}$

$\begin{array}{ll}\text { Activity and impact on policy } & 218\end{array}$

$\begin{array}{ll}7.3 \text { Conclusion } & 223\end{array}$

8. Conclusion …...............................................................................................227

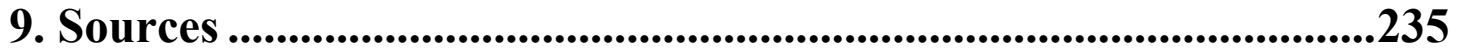

9.1 Interviewees 235

$\begin{array}{ll}9.2 \text { Primary and secondary literature } & 238\end{array}$

Author's Curriculum Vitae ..............................................................261

\section{List of Figures}

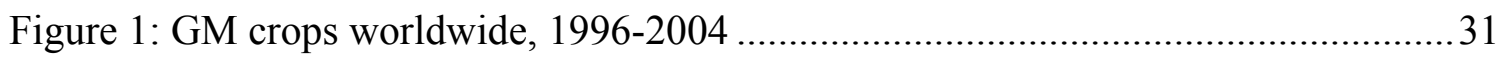

Figure 2: GM crops by type of crop, 1996 and 2004 (in percent) ................................... 31

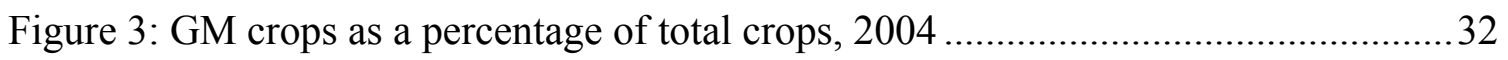

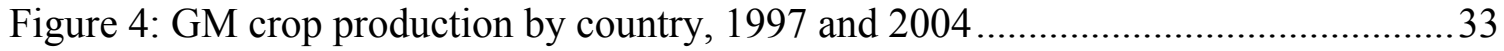

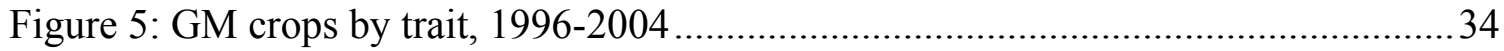

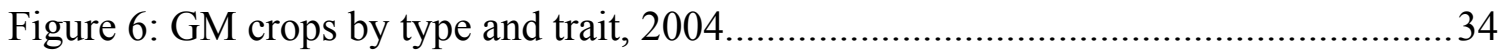

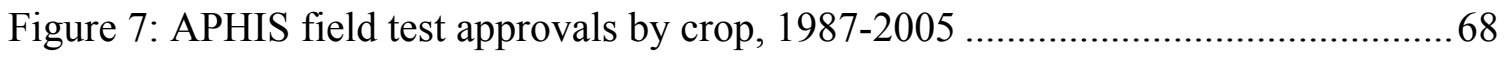

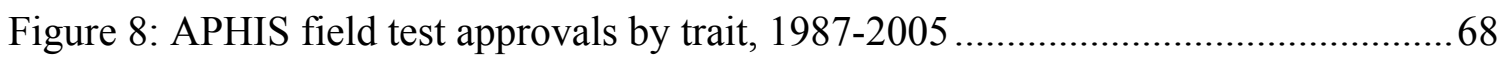

Figure 9: EU field test approvals by type of crop, 1991-2005 …...................................69

Figure 10: APHIS nonregulated GM crops, by type of crop (May 2005) ........................73

Figure 11: Completed FDA consultations on GM food, 1994-2004 ............................... 77

Figure 12: Completed FDA consultations by type of GM food, 1994-2005 ................... 77

Figure 13: GM food policy differences: analytical framework ................................. 121

Figure 14: Analytical framework including variable interdependence ..........................231

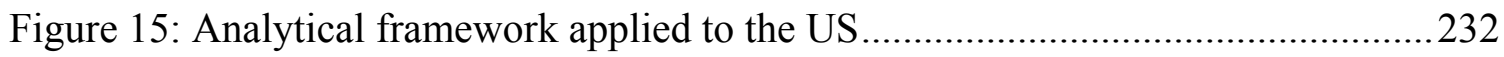

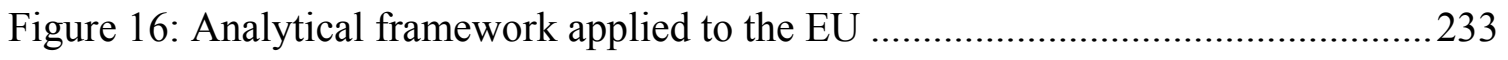




\section{List of Tables}

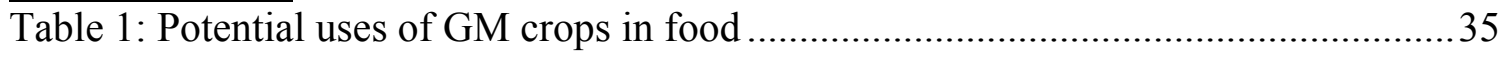

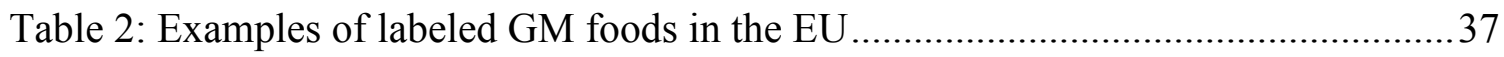

Table 3: The pros and cons of agricultural biotechnology ........................................... 40

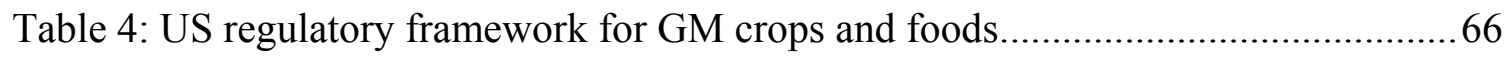

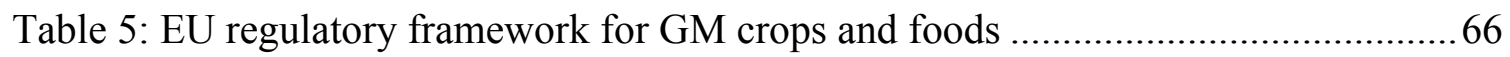

Table 6: US and EU field test regulations for GM plants (as of 1 Aug. 2005) ................ 71

Table 7: US and EU field test authorizations for GM plants (1991-2005).......................72

Table 8: US and EU regulation of GM product commercialization (as of 1 Aug. 2005). 83

Table 9: US and EU GM food and crop commercialization (1991-2005) .......................85

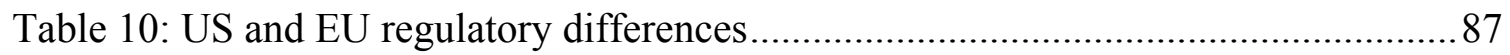

Table 11: Theoretical basis for explanatory variables .................................................. 109

Table 12: Differences between advocacy and discourse coalitions............................... 118

Table 13: Preceding policies in the United States and the European Community .......... 145

Table 14: US corn and soybean production, total exports, exports to the EU................ 161

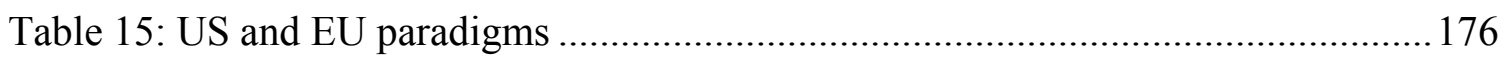

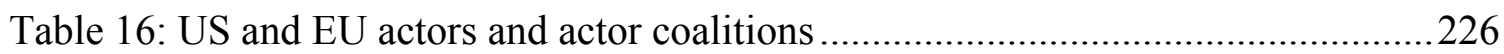




\section{Abstract}

How and why are genetically modified (GM) food policies in the United States (US) and the European Union (EU) different? This is the research question addressed in this dissertation.

The regulatory structures underlying United States and European Union policies regarding genetically modified food and crops are fundamentally different. The US regulates GM foods and crops as end products, applying the same regulatory framework that it would to non-GM foods or crops. The EU, on the other hand, regulates agricultural biotechnology products as the result of a specific production process, and has developed a series of rules that regulate GM foods and crops. This key difference is reflected in distinct procedures for the authorization of field trials and commercialization. The result is a relatively permissive US regulation of GM food and crops, and a relatively restrictive regulatory system in the EU.

Drawing on policy process theory, comparative historical analysis, and science and technology studies, this dissertation contends that differences between genetically modified food policies in the US and the EU can be explained by three main elements. First, US and EU policies regarding recombinant DNA research in the 1970s and 1980s and events leading up to early GM food and crop regulation allow a deeper understanding of how current policies were able to develop ("preceding policies"). Second, underlying beliefs and values condition the content of current GM food and crop policy ("paradigms"). Third, actors for and against agricultural biotechnology have achieved different levels of success in influencing GM food policies in the US and the EU ("actors and actor coalitions"). These three explanatory variables are further influenced by context factors such as political systems, public opinion and "shock events".

Keywords: genetically modified food, genetically engineered food, agricultural biotechnology, regulation, public policy, policy process theory, comparative historical analysis, science and technology studies. 


\section{ACKNOWLEDGMENTS}

First and foremost, I wish to thank my advisers, Professor Daniel Kübler, Professor Frédéric Varone, and the late Professor Ulrich Klöti, for their consistent support and insightful comments on my work.

I have been very fortunate in being able to research and write this dissertation within diverse contexts. Three years were spent as a research and teaching assistant at my home institute, the University of Zurich's Department of Political Science (2000/01-2002/03). During this period, I received financial support from the Swiss Federal Institute of Technology to spend a year at the Collegium Helveticum (2001/02), an institute emphasizing interdisciplinary dialogue among the natural sciences, social science, humanities, and the arts, and where my work was much enriched by my discussions with Professor Helga Nowotny.

A scholarship from the Swiss National Science Foundation enabled me to pursue my project further afield as of the autumn of 2003. I first spent one year at Harvard University's John F. Kennedy School of Government (2003/04), where I benefited from Professor Sheila Jasanoff's illuminating observations. I then completed the writing of this dissertation during a year spent at the European University Institute in San Domenico di Fiesole (2004/05), where Professor Adrienne Héritier and Professor Rikard Stankiewicz offered further valuable comments.

Among the many other individuals that have helped me complete this project, I would especially like to acknowledge the lobbyists, government officials and scholars who generously granted me interviews in Brussels, Cambridge and Medford, Massachusetts, and Washington, DC.

Celina Ramjoué

June 2007 


\section{ACRONYMS AND ABBREVIATIONS}

$\mathrm{ABF}$

$\mathrm{ACF}$

ACGA

ACNFP

AFBF, Farm Bureau

AIDS

APHIS

ARM

art.

ASA

BEUC

$\mathrm{BIO}$

BSE

$\mathrm{Bt}$

CAP

CEQ

CFR

CFS

CFSAN

CFSP

CIAA

CJD

Commission

COPA-COGECA

Council

CPE

CRG

CRP

$\mathrm{CU}$
Alliance for Better Foods

Advocacy Coalition Framework

American Corn Growers Association

UK Advisory Committee on Novel Foods and Processes

American Farm Bureau Federation

Acquired Immune Deficiency Syndrome

Animal and Plant Health Inspection Service

antibiotic resistance marker

Article

American Soybean Association

Bureau européen des consommateurs (European Consumers' Organisation)

Biotechnology Industry Organization

Bovine Spongiform Encephalopathy

Bacillus thuringiensis

Common Agricultural Policy

Council on Environmental Quality

Code of Federal Regulations

Center for Food Safety

Center for Food Safety and Applied Nutrition

Common Foreign and Security Policy

Confederation of the Food and Drink Industries of the European Union

Creutzfeldt-Jakob disease

European Commission

Committee of Professional Agricultural Organisations in the European Union and General Confederation of Agricultural Co-operatives in the European Union

Council of the European Union

Coordination Paysanne Européenne (European Farmers Coordination)

Council for Responsible Genetics

Conservation Reserve Program

Consumers Union 


\begin{tabular}{|c|c|}
\hline DC & District of Columbia \\
\hline DG & Directorate General \\
\hline Dir. & EU Directive \\
\hline DNA & deoxyribonucleic acid \\
\hline EA & Environmental Assessment \\
\hline $\mathrm{EC}$ & European Community \\
\hline ECSC & European Coal and Steel Community \\
\hline ed., eds. & editor(s) \\
\hline EEC & European Economic Community \\
\hline EFSA & European Food Safety Authority \\
\hline e.g. & for example (exemplia gratia) \\
\hline EIS & Environmental Impact Statement \\
\hline EMBO & European Molecular Biology Organisation \\
\hline EP & European Parliament \\
\hline EPA & Environmental Protection Agency \\
\hline ESF & European Science Foundation \\
\hline et al. & and others (et alii) \\
\hline et seq. & and those that follow (et sequential) \\
\hline etc. & and so forth (et cetera) \\
\hline EU & European Union \\
\hline EUP & Experimental Use Permit \\
\hline EURATOM & European Atomic Energy Community \\
\hline EuropaBio & The European Association for Bioindustries \\
\hline FAO & Food and Agriculture Organization \\
\hline FDA & Food and Drug Administration \\
\hline FFDCA & Federal Food, Drug, and Cosmetic Act \\
\hline FIFRA & Federal Insecticide, Fungicide, and Rodenticide Act \\
\hline fig. & figure \\
\hline FMD & Foot and Mouth Disease \\
\hline FONSI & Finding Of No Significant Impact \\
\hline FPA & Food Products Association (former National Food Processors Association) \\
\hline GATT & General Agreement on Tariffs and Trade \\
\hline GE & genetically engineered \\
\hline
\end{tabular}




\begin{tabular}{|c|c|}
\hline GM & genetically modified \\
\hline GMA & Grocery Manufacturers of America \\
\hline GMAG & Genetic Manipulation Advisory Group \\
\hline GMO & genetically modified organism \\
\hline GRAS & Generally Recognized As Safe \\
\hline HHS & United States Department of Health and Human Services \\
\hline HIV & Human Immunodeficiency Virus \\
\hline i.e. & that is (id est) \\
\hline ibid. & in the same place (ibidem) \\
\hline IPR & intellectual property rights \\
\hline JHA & Justice and Home Affairs \\
\hline MA & Massachusetts \\
\hline MEP & Member of the European Parliament \\
\hline NAS & National Academy of Sciences \\
\hline NCGA & National Corn Growers Association \\
\hline NFFC & National Family Farm Coalition \\
\hline NFPA & National Food Processors Association (now Food Products Association) \\
\hline NEPA & National Environmental Policy Act \\
\hline NGO & non-governmental organization \\
\hline $\mathrm{NIH}$ & National Institutes of Health \\
\hline NIH RAC & National Institutes of Health Recombinant DNA Advisory Committee \\
\hline No., Nos. & number(s) \\
\hline NSF & National Science Foundation \\
\hline OECD & Organisation for Economic Co-operation and Development \\
\hline OFPA & Organic Foods Production Act \\
\hline OSTP & Office of Science and Technology Policy \\
\hline Parliament & European Parliament \\
\hline $\mathrm{PCBs}$ & polychlorinated biphenyls \\
\hline PIP & plant-incorporated protectant \\
\hline PJCC & Police and Judicial Co-operation in Criminal matters \\
\hline PMP & plant-made pharmaceutical \\
\hline PPA & Plant Protection Act \\
\hline QCA & qualitative comparative analysis \\
\hline
\end{tabular}


$R \& D$

$\mathrm{RAC}$

rDNA

Reg., Regs

RTD

SPS Agreement

STS, S\&TS

TBT Agreement

TSE

UCS

UK

UN

US, USA

USC, US Code

USDA

US PIRG

USSR

vCJD

Vol., Vols.

WHO

WTO
Research and Development

Recombinant DNA Advisory Committee

recombinant deoxyribonucleic acid

EU Regulation(s)

Research and Technology Development

Agreement on the Application of Sanitary and Phytosanitary Measures

science and technology studies/science, technology and society/science studies

Agreement on Technical Barriers to Trade

Transmissible Spongiform Encephalopathy

Union of Concerned Scientists

United Kingdom

United Nations

United States, United States of America

United States Code

United States Department of Agriculture

United States Public Interest Research Group

Union of Soviet Socialist Republics

variant Creutzfeldt-Jakob disease

volume(s)

World Health Organization

World Trade Organization 


\section{INTRODUCTION}

\subsection{Research question}

Genetically modified (GM) food has been a prominent area of worldwide public controversy since the late 1990s. Agricultural products of "modern biotechnology"1 began to be developed starting in the 1980s and early 1990s, mainly by United States (US) multinational corporations, with the help of socalled rDNA technology (recombinant deoxyribonucleic acid technology) developed by US scientists in the 1970s. 1996 saw the first planting, harvesting, and exporting of GM crops. First food products containing genetically modified organisms $(\mathrm{GMOs})^{2}$ found their way onto US supermarket shelves shortly afterwards. In 1996, the acronym GMO was largely unknown to the US and European publics and the value of the GM crop market was estimated at US\$115 million (James 2004: 26). By 2004, this figure had leapt to US\$4.66 billion (ibid.), and GM foods had become the object of a major international debate. Over the past few years, European consumers have rejected GM foods relatively consistently (European Commission 2003, European Commission 2005b). In contrast, US consumers remain comparatively accepting (Pew Initiative on Food and Biotechnology 2004b). Moreover, since 2003, the United States and the European Union (EU) have been engaged in a World Trade Organization (WTO) dispute over international trade in GM crops.

Central to these turbulent years is the question of how to regulate GM foods and crops. Since the 1980s, regulators on both sides of the Atlantic have

\footnotetext{
${ }^{1}$ Biotechnology is the use of living organisms and biological processes to manufacture products. In its traditional sense, biotechnology includes the methods used to ferment beer, bake bread and culture cheese. Within the GM food debate, the word "biotechnology" has taken on the meaning of "biotechnology using genetic engineering", i.e. technology that can modify biological processes and organisms, and specifically their genetic makeup. Main areas of application of this "modern biotechnology" are agriculture ("green biotechnology": GM foods and crops), medicine ("red biotechnology": pharmaceuticals), and industry ("white biotechnology": enzymes, plastics, fuels, etc.). In this dissertation the term "biotechnology" is used to mean modern biotechnology. On the meaning of modern biotechnology versus traditional or conventional biotechnology, see, for example, Glowka 2003, McKelvey et al. 2004, or Reuter 2003.

${ }^{2}$ A genetically modified organism (GMO) is an organism (e.g. plant, animal, bacterium, virus) whose genetic material has been altered. GM foods and crops are examples of GMOs.
} 
struggled to determine whether and under what conditions these biotechnology applications should be permitted to be released into the environment and enter commercial markets. The questions of GM food labeling and traceability ${ }^{3}$ were widely deliberated during the 1990s. More recent topics debated by regulators include the issues of liability ${ }^{4}$, coexistence ${ }^{5}$, the labeling threshold for GM seed ${ }^{6}$, and intellectual property rights (IPR) ${ }^{7}$.

Both US and EU policies are driven by the general assumption that modern biotechnology is a driver of economic growth. The EU reiterated this view in 2000 by launching the Lisbon strategy which aims to make the European Union "the most dynamic and competitive knowledge-based economy in the world" by 2010 (European Council 2000). Supporting the development of biotechnology is one of the ways in which the EU intends to achieve this goal. "Red" biotechnology (pharmaceuticals) and "white" biotechnology (industrial products) have been rather successful in both the US and Europe. In contrast, "green" biotechnology (agricultural products such as GM crops) has done well in the US, but not in the EU, with EU regulators demonstrating a high degree of caution in comparison with other biotechnology applications.

3 Traceability of GM food is a concept introduced in 2003 by the European Parliament and Council of the EU's regulation on traceability and labeling (EP/Council Reg. 1830/2003, European Parliament/Council of the European Union 2003b). It defines traceability as "the ability to trace GMOs and products produced from GMOs at all stages of their placing on the market through the production and distribution chains".

${ }^{4}$ Liability refers to the question of legal responsibility for potential damages caused by GM crops and foods. The fundamental issue at stake is who would be liable for damages, for example, to the environment: farmers, seed retailers, or agricultural biotechnology companies? In the case of damage to health, are supermarkets, food producers or agricultural biotechnology companies responsible?

${ }^{5}$ Coexistence is the term used in connection with the debate on setting up rules on how farmers should physically separate traditional, organic and genetically modified crops to avoid so-called "contamination" or "genetic contamination".

${ }^{6}$ Proposals for a GM threshold in seed have ranged from $0.3 \%$ to $0.7 \%$, but no agreement has been reached so far. In September 2005, the European Commission for the first time approved the inscription of GM seed varieties (17 varieties derived from MON 810, a specific type of GM corn) into the Common EU Catalogue of Varieties of Agricultural Plant Species. GM seed varieties can be inscribed only after having been authorized in the EU.

${ }^{7}$ Intellectual property rights (IPR) are the exclusive rights over the use of an invention, often for a defined period of time. Forms of IPR used in the field of agricultural biotechnology include patents and trademarks. Agricultural biotechnology companies claim intellectual property rights over their products in order to guarantee a profitable return on their investments. Critics of GM foods and crops, however, question whether it is ethical to allow ownership of forms of life. Developing countries fear that industry will come to own elements of their indigenous biodiversity, genetic material, and knowledge without authorization and without offering fair compensation ("biopiracy"). 
US and EU policies regulate the same products, and yet they are strikingly different. In essence, US policy ${ }^{8}$ is relatively permissive, while EU policy is relatively restrictive ${ }^{9}$, as is indicated by the fact that the US has authorized significantly higher numbers of GM crops and foods than the EU. ${ }^{10}$ Underlying this phenomenon are fundamentally different regulatory structures regarding genetically modified food. When confronted with a new GM food or crop, US regulators use the same framework that they apply to non-GM products and generally assess the safety of GM foods with the help of the principle of "substantial equivalence" ". The EU has also periodically used this concept, but in building a network of legislation and regulations ${ }^{12}$ developed specifically for GMOs, it now emphasizes the "precautionary principle"13. As a result, processes leading to authorizations tend to represent less of an obstacle in the United States than in the European Union.

Despite the forces of globalization ${ }^{14}$ at work since the 1990 s, GM food policies are not converging. In fact, the opposite is the case. In the US, although regulating agencies have experimented with policy instruments including voluntary labeling and pre-market consultations, the regulatory environment remains essentially "GM food friendly", and the few new rules and regulations

\footnotetext{
${ }^{8}$ The term "policy" is defined and discussed under 1.2.

9 "Permissive" can be defined as lax, unrestrained, unbound. "Restrictive" means stringent, restrained, limited.

${ }^{10}$ Chapter 3 offers an in-depth discussion of GM food policy differences, including numbers of authorizations.

${ }^{11}$ Substantial equivalence refers to the concept that new food products (e.g. GM foods) can be treated in the same manner as an existing food (e.g. non-GMO food) with respect to safety if it is comparable in terms of its composition and characteristics (e.g. nutrients, toxicants, allergens). The concept was first introduced by the Organisation for Economic Co-operation and Development (OECD) in its 1993 report on "Safety Evaluation of Foods Derived by Modern Biotechnology", which stated that "[T]he concept of substantial equivalence embodies the idea that existing organisms used as food, or as a source of food, can be used as the basis for comparison when assessing the safety of human consumption of a food or food component that has been modified or is new" (Organisation for Economic Co-operation and Development 1993: 11). In 1996, the United Nations's (UN) Food and Agriculture Organization (FAO) and the World Health Organization (WHO) reiterated this concept (Food and Agriculture Organization/World Health Organization 1996).

${ }^{12}$ The term "regulation" is defined and discussed under 1.2.

${ }^{13}$ The precautionary principle refers to the concept that "where there are threats of serious or irreversible damage, lack of full scientific certainty shall not be used as a reason for postponing cost-effective measures to prevent environmental degradation" (Principle 15 of the so-called Rio Declaration, United Nations General Assembly 1992), see 6.2 for further details.

${ }^{14}$ Globalization can be defined as the growing integration of economies, cultures, and public policies around the world.
} 
that have been applied to GM foods and crops since the mid-1980s are consistent with the relatively permissive original regulatory framework. In contrast, although the EU does not prohibit GM foods and crops, its policies have become increasingly stringent in the wake of a wave of public protest against food biotechnology starting in the late 1990s and continuing into the present.

After several years of failed diplomatic attempts to bridge this widening transatlantic gap, US and EU GM food policy differences have led to a trade disagreement currently being played out on the level of the World Trade Organization (WTO). On 13 May 2003, the United States, Canada and Argentina brought a WTO complaint against the European Union for hindering trade with GM food and crops (World Trade Organization 2003). It lists the EU's de facto moratorium, in place since 1998, as well as individual EU Member States' national bans ${ }^{15}$ as being inconsistent with provisions of several WTO agreements: the 1994 General Agreement on Tariffs and Trade (GATT) (“GATT 1994”) 16, the World Trade Organization Agreement on the Application of Sanitary and Phytosanitary Measures ("STS Agreement"), and the World Trade Organization Agreement on Technical Barriers to Trade ("TBT Agreement"). In this still unresolved dispute ${ }^{17}$, while the European Union invokes the precautionary principle to justify its policy, the United States views EU policies as protectionist measures incompatible with international trade agreements.

The transatlantic regulatory and trade clash over GM food has also extended to the developing world, in particular since the beginning of the new

${ }^{15}$ The EU's so-called de facto moratorium and national bans of GMOs are described in 2.3.

16 The original General Agreement on Tariffs and Trade (GATT) was signed in 1947 by 23 nations (General Agreement on Tariffs and Trade 1947). It consisted of a series of tariff concessions and rules designed to prevent restrictive trade measures. Since then, there have been seven further rounds of trade negotiations, culminating in the Uruguay Round (eighth round), which lasted from 1986 to 1993. After the conclusion of the Uruguay Round, the original GATT of 1947 was updated to "GATT 1994" (General Agreement on Tariffs and Trade 1994), and the World Trade Organization (WTO) was established in 1995. WTO's rules are laid down in GATT 1994 and a series of other agreements. The WTO pursues the goal of promoting free trade, fair competition, and economic development. Despite a consistent commitment to free trade, these texts contain language that, according to interpretation, could or could not accommodate the precautionary measures adopted by the EU in the case of GMOs. For example, the GATT Agreement states that "[...] nothing in this agreement shall be construed to prevent the adoption $[\ldots]$ of measures $[\ldots]$ necessary to protect human, animal or plant life or health [... ]" (General Agreement on Tariffs and Trade 1994, art. XX). The TBT and SPS Agreements contain similar provisions.

${ }^{17}$ The final ruling on the case has been delayed several times. At the time of writing, it is planned for the end of March 2006. 
millennium. Promoters of agricultural biotechnology, including the United States government, maintain that GM crops can play an important part in combating problems such as hunger and malnutrition, for example, by the use of genetically modified drought and pest-resistant crops. GM food critics including organizations like Friends of the Earth and Greenpeace, as well as some European political parties and national governments, affirm that agricultural biotechnology does nothing to address the roots of developing countries' troubles while simultaneously rendering them dependent on expensive technologies from multinational biotechnology companies.

This conflict was played out in a flamboyant manner in 2002, when Zambia refused a US donation of GM corn to help combat malnutrition and starvation, based on its fear of GM varieties entering Zambian agricultural production. Zambia's main reason for its action was the fear that future Zambian crops could become at least partly genetically modified, thus impairing Zambian trade relations with GM food and crop adverse trading partners such as the EU. The United States requested, but was denied, support from the EU in encouraging Zambia to accept the donation. The incident led to a polemic discussion in which the US charged the EU with partial responsibility for hunger in Africa, while some EU countries hinted that the US was exploiting the southern African food crisis for commercial and trade purposes. In the end, international donors delivered sufficient non-GM food aid to Zambia to diffuse the crisis. ${ }^{18}$

In the light of the regulatory differences and recurring disputes between the US and the EU, this dissertation seeks to answer the following research question: How and why are GM food policies in the United States and in the European Union different? A comparison between the EU and the $\mathrm{US}^{19}$ is both appropriate and politically relevant. It is appropriate because the EU and the US federal government have regulatory authority over GM foods. In European Union countries, GM plants to be tested and GM foods and crops to be commercialized

\footnotetext{
${ }^{18}$ On this particular incident, see, for example, the newspaper articles "US to give hungry Zambia food despite GM spat" (2002) and "EU Declines US Call to Reassure Africa on GMO" (2002). Examples of literature on the debate on whether agricultural biotechnology can benefit developing countries include Shiva 2001 and Trewavas 2002.

${ }^{19}$ Considering that positions among EU countries are also different, a further interesting area of study is the comparison of EU Member State policies and approaches regarding GM foods. Examples of multi-country studies include Bauer/Gaskell 2002, Durant/Bauer/Gaskell 1998, Gaskell/Bauer 2001, and Levidow/Carr/Wield 1999a.
} 
are regulated at the EU level. Member States implement EU-level laws, often by drafting specific national legislation. In the US GM food regulation falls under the competence of the federal government. US states cooperate with the government to implement specific federal laws. It is politically relevant, especially because transatlantic regulatory differences have led to an international trade dispute within the World Trade Organization, initiated by several main GM crop producers and exporters (US, Canada and Argentina), but led by the US, and directed against the EU. ${ }^{20}$

\subsection{Time span covered and definitions}

This dissertation first and foremost seeks to explain policy differences across cases, i.e. to compare the policy outcomes of two cases at a specific point in time. It does not seek to conduct a systematic comparison of policy across time, as might be done to explain policy change. The analytical focus of this dissertation lies in the present and ongoing period of political controversy surrounding GM foods and crops, which began in the late 1990s and persists to this day. The detailed description of US and EU genetically modified food policies (Chapter 3), this study's dependent variable, takes into account policy changes until August 2005. These are the policy outcomes that this dissertation seeks to explain. In explaining policy differences across cases, I sometimes make reference to policy change across time as part of my analysis. For example, in my discussion of policies preceding GM food policies (Chapter 5), I reach back into the phase of rDNA research regulation, as well as the early phase of the regulation of biotechnology applications (1970s, 1980s and early 1990s).

\footnotetext{
${ }^{20}$ European non-EU countries and countries in North, Central and South America other than the United States are not explicitly considered in this dissertation. It is worth noting that non-EU European countries' GM food policies are generally more similar to EU policies than to US policies, while some other North, Central and South American countries have policies that are more similar to US policies than to EU policies (especially Canada and Argentina). On the European side, this can be partly explained by trade agreements between the EU and European non-EU countries. On the American side, the "US GM food policy-friendly" countries are large GM crop and food producers who share the US's interest in promoting trade with regard to their produce. It can therefore be argued that studying EU and US policies means studying the two main currently relevant GM food policy regulatory systems. Major Asian countries' regulations lie somewhere in between the extreme US and EU positions, with countries such as China, Indonesia, India, or Japan adopting intermediate and sometimes ambivalent positions with respect to agricultural biotechnology (Barboza 2003, Feffer 2004, Montpetit/Rothmayr/Varone forthcoming).
} 
Analyses of the role of paradigms, and of actors ${ }^{21}$ (or stakeholders ${ }^{22}$ ) and actor coalitions primarily focus on the period from the mid-1990s to the present (Chapters 6 and 7).

Genetically modified foods are foods produced by or containing ingredients resulting from genetic transfers between different species. While traditional breeding is possible only within the same species, GM crops typically include a trait from an unrelated species. Although this dissertation uses only GM food in its title, it deals with the regulation of both GM crops and foods. GM food and GM crops are inextricably linked since the harvests of GM crops are used as ingredients in GM foods. ${ }^{23}$ Chapter 2 gives an overview of existing GM foods and crops.

European refers to the European Union (and the European Community [EC] until 1992) 24 $^{24}$ and its institutions ${ }^{25}$, and Europeans to the citizens of the

${ }^{21}$ In this dissertation the term "actor" is used to mean an active or passive participant in a policy debate. Actors can be individual or collective (organizations, companies, etc.).

${ }^{22}$ For the purposes of this dissertation, a "stakeholder" is an individual or collective actor (organization, institution, etc.) who has an interest (a stake) in a policy issue or the outcome of a policy decision.

${ }^{23}$ A further, intimately linked area is GM feed (for animal consumption), which is important because a large percentage of GM crops is processed to produce GM feed, both in the EU and in the US. The issue of GM feed has been addressed only recently by EP and Council Regulations 1829/2003 and 1830/2003 of 2003 (European Parliament/Council of the European Union 2003a, 2003b). In contrast, the US does not regulate GM feed at all. In this dissertation, I focus on GM food. The issues and actors within the GM feed debate are similar enough to the GM food and crop debate to not necessitate separate treatment. Another developing GM plant specialization is the production of so-called PMPs (plant-made pharmaceuticals), as they are called by the US Department of Agriculture (USDA). The regulation of plants producing PMPs is already being discussed, especially in the United States where introduction is more imminent than in the EU.

${ }^{24}$ The European Union is the result of the process of European integration, which began with the creation of the European Coal and Steel Community (ECSC) in 1952. In 1957 the Treaties of Rome created the European Economic Community (EEC) and the European Atomic Energy Community (EURATOM). In 1967, these three Communities merged, and became known as the European Communities or European Community (EC). After the Treaty of Maastricht came into force in 1993, the European Community was renamed the European Union. European Union policy areas consist of the so-called Community pillar, which contains policy areas dealt with by the previous European Community, the Common Foreign and Security Policy (CFSP) pillar, and the Justice and Home Affairs Pillar (JHA), which was subsequently renamed "Police and Judicial Co-operation in Criminal matters" (PJCC).

25 Main European Union institutions are the European Commission ("Commission"), the European Parliament (EP or "Parliament"), and the Council of the European Union ("Council"). The European Commission generally proposes new legislation, whereas the Council and Parliament pass laws, jointly in many policy areas. 
European Union's Member States ${ }^{26}$, whereas American and Americans are short forms for US-American and US citizens.

Policy should be understood in contrast to polity (the political order and institutional rules within which policy is shaped) and politics (the political process defined by conflict, bargaining and differing interests, which may lead to policy). In this context, policy constitutes the content-oriented dimension interacting with and defined by polity and politics (see, for example, Schubert 1991: 26). Public policy, often abbreviated policy, can be defined as "what governments do, why they do it, and what difference it makes" (Dye 1976), or as "anything a government chooses to do or not do" (Dye 1972). It can further be understood as "a process or a series or pattern of governmental activities or decisions that are designed to remedy some public problem, either real or imagined" (Lester/Stewart 1996: 5). According to Lowi (1964, 1972), "regulatory policy" or "regulation" is a type of policy. ${ }^{27}$ It can be defined as policies that reduce or expand individual actors' alternatives through prohibitions, restrictions or rules, usually in the form of laws and administrative regulations. Following this definition, GM food policy is predominantly regulatory (see, for example, Pollack/Shaffer forthcoming). This dissertation therefore refers to GM food policy and regulation interchangeably.

\footnotetext{
${ }^{26}$ At present there are 25 EU Member States. Belgium, France, Germany, Italy, Luxembourg, and the Netherlands are the founding members of the European Coal and Steel Community, the European Economic Community, and the European Atomic Energy Community. Denmark, Ireland and the United Kingdom joined the European Community in 1973. Greece became the tenth Member State in 1981, followed by Spain and Portugal in 1986. In 1995, Austria, Finland and Sweden joined what had become the European Union in 1993. In 2004, 10 further Member States joined the EU: Cyprus, Czech Republic, Estonia, Hungary, Latvia, Lithuania, Malta, Poland, Slovakia, and Slovenia.

${ }^{27}$ Other types of policy are "distributive" (e.g. infrastructure projects within transport policy), "redistributive" (e.g. taxes within welfare policy), and "constitutive" (e.g. the creation of an agency) (Lowi 1964, 1972). More recent authors transport the notion of regulation into the era of globalization. For instance, Majone describes the recent rise of a "regulatory state" in Europe, and especially the European Union, based on expert statutory regulation by independent agencies, and modelled on the US regulatory state (Majone 1994a, Majone 1994b). Levi-Faur develops the concept of "regulatory capitalism", a hybrid between laissez-faire and welfare capitalism, in which the state retains steering functions, while business takes over the provision of services and technological innovation, for example, through privatization of functions previously provided by the public sector (Levi-Faur 2005).
} 


\subsection{The transatlantic rift in GM food policy: literature review}

Existing studies that seek to explain US and EU differences in GM food policy are embedded within the wider field of literature on the GM food policy debate. This area of scholarship exploded in the late 1990s, together with the rise of GM food as an area of controversy, and is still growing steadily. The following literature review takes the field as a whole into account, but in particular emphasizes studies dealing explicitly with GM food policy in the US and the EU. These are discussed in terms of empirical fields covered, theoretical approaches used, and hypotheses, propositions and results formulated.

\section{Empirical fields}

Recurrent topics other than EU and US regulation A fair share of literature on GM foods and crops is written by non-social scientists, for example, members of advocacy groups, journalists, former government officials or natural scientists. Some is normative ${ }^{28}$ and takes a more or less clear side in the GM food policy debate. These studies are not theory-driven and do not develop hypotheses as to why regulation is the way it is. Instead, they often aim to cast agricultural biotechnology in a positive (e.g. Federoff/Brown 2004, Miller/Conko 2004) or negative light (e.g. Cummins/Lilliston 2004, Hart 2002, Nottingham 2003, Smith 2003, Tudge 2004). Other studies that are not theory-based are first and foremost interested in providing an informative narrative of the GM food and crop debate (Charles 2001, Kempf 2003, Lambrecht 2001).

One prominent area of scholarship within the field of social science is the study of the public's understanding of GM foods and its opinion of them. Studies focusing on public opinion (e.g. Bauer/Gaskell 2002, Durant et al. 1998, Gaskell 2000, Gaskell at al. 1999, Gaskell at al. 2002, Gaskell/Bauer 2001) use opinion polls and media sources to describe and explain differences in public opinion. They use institutional and interest-based approaches, as well as cultural explanations. For example, Gaskell et al. (2002) explain differences between US and EU public opinion by considering "media coverage", "scientific knowledge",

28 "Normative" means establishing "a standard of correctness by prescription of rules" (definition from Flew 1999). 
and "trust in regulatory systems" for both cases. Their main argument is that "different histories of media coverage and regulation go together with different patterns of public perceptions, and [that] these in turn reflect deeper cultural sensitivities" towards food, novel food, agriculture and the environment (Gaskell et al. 2002: 373-374). Studies of the public understanding of science (e.g. Greenberg/Graham 2000, Wynne 2001), on the other hand, primarily analyze and often critique perceptions of "the public", and the limited possibilities of participation in policy-making processes involving GM foods. Wynne, for example, holds that "skeptical public reactions are not a reaction to (supposedly misperceived) risks as such, but rather are public judgments of dominant scientific and policy institutions [...]" (Wynne 2001: 445). In accordance with their focus, studies on public opinion do not attempt to explain the reasons for policy differences.

A further important body of scholarship relevant to the topic of this dissertation is made up of studies focusing on GM food in the light of transatlantic trade issues. Some of these address US-EU differences as a preliminary step to discussing their implications for trade. In her 2002 study, Hennis's starting point is the observation that recent trade disputes have shifted their focus from tariffs and domestic protectionism to food safety and environmental protection issues. In her analysis, "regional regulatory differences" between the US and EU are a result of globalization and different models of agricultural production. Like Hennis, Isaac (2002) presents the differences in GM food policy as an obstacle to trade. He argues that new "social regulatory barriers" set up to meet moral, ethical and religious preferences have led to different regulations or "regulatory regionalism", and goes on to suggest solutions to this state of affairs, implying that it should be overcome. Yet another scholar approaching the issue of GM food through a trade lens is Young (2001), who discusses implications for trade and the future of divergent regulations. Patterson and Josling (2002) take a similar approach, but in addition offer an enumeration of possible cultural, political and institutional reasons for regulatory differences. Finally, Paarlberg (2002) focuses on trade in relation to the developing world, and predicts that the EU will prevail in the transatlantic conflict over agricultural biotechnology since big importers like the EU are more apt to set the safety and labeling rules than big exporters like the US. 
A number of trade-related studies focus specifically on the WTO dispute (Herwig 2004, La Rosa-Ames 2003, Winickoff et al. 2005). Herwig's discussion of WTO law is constructivist ${ }^{29}$, and its purpose is to analyze and critically discuss the WTO's regulation of GM foods. La Rosa-Ames's analysis reviews EU regulations on GM foods, and concludes that these are incompatible with WTO rules. Winickoff et al. propose to tackle the WTO dispute by using a "judicial approach" instead of a science-based approach, i.e. by studying the risk assessment process through a social, economic and ethical rather than sciencebased lens.

Studies on the US or on the EU A growing number of non-comparative studies look at GM food policy only in the EU or only in the US. Like public opinion studies, they take a variety of theoretical approaches. Some important works dealing mainly with the EU include Abels (2002), Ashford (1996), Christoforou (2004), Groß (2001), Levidow/Carr/Wield (1999b, 2000, 2005), Levidow/Murphy (2002), Rücker (2000), and Skogstad (2003). Examples of studies emphasizing the US case are Dawkins (2003), Klintman (2002), Krimsky (2000), Krimsky/Murphy (2001), Pollack/Shaffer (forthcoming), Pringle (2003), Sheingate (2004), Teitelman (1989) and Winston (2002). This literature offers detailed empirical information on the individual case studies.

Literature on the transatlantic rift in GM food policy Amidst the wide field of literature on the GM food debate, studies offering comparative views on US and EU GM food policy are fairly uncommon, and in-depth explanations of the transatlantic rift in genetically modified food policy are quite rare. Significant contributions are offered by Meins (2003), Bernauer/Meins (2003), and Bernauer (2003). Meins explains different levels of stringency and laxness ${ }^{30}$ in the cases of GM food labeling requirements in the US and the EU, and of food irradiation ${ }^{31}$ regulation in France and Germany. Vogel (2001) offers a compelling if compact

\footnotetext{
${ }^{29}$ Constructivism is based on the idea that individuals' knowledge and understanding of the world is constructed through reflection. Applied to the area of science and technology, this means that scientific knowledge is shaped by material and cultural resources, and that it is not the result of a revelation of a pre-given natural order.

${ }^{30}$ Meins defines stringency as the "dimension of state intervention". For the case of GM food labeling, "regulation is lax if no [...] labelling at all is required for the selling of a product" whereas regulations "are stringent if they require mandatory labelling" (Meins 2003: 39).

${ }^{31}$ Food irradiation is the exposure of food to radiation, with the goal of sterilizing or preserving food.
} 
explanation of regulatory differences in his study focusing on the differences between US and EU regulation as part of a more general discussion of regulatory differences in the fields of health and the environment. Further important contributions come from the field of science and technology studies (STS). Scholars from this area have explored individual issues relevant to the transatlantic debate on GM food policy. For example, Wright (1994) and Gottweis (1998) offer detailed discussions of the early phases of biotechnology regulation in the US and in Europe. Levidow (1999b) compares the regulation of insect resistant GM corn regulation in the EU and the US, and Joly and Marris (2001) investigate differences between the ways in which GMOs influence and are part of agenda-setting in the US and France, and focus on "identifying the different frames of reference utilized" on each side of the Atlantic. An STS scholar who explores biotechnology policy from a constructivist, cultural, comparative, and legal perspective is Jasanoff (1995). Toke (2004) gives a constructivist, but more sociological perspective, and Epp (2003) offers a contribution located at the intersection of sociology and law in a study of GM food policy in the US and Germany.

\section{Theoretical approaches}

Most studies on the transatlantic rift on GM food policy are based on one of two theoretical approaches. They either underline the explanatory role of economic interests and institutions (political economy approach), or emphasize cultural and belief-based explanations.

Political economy approach Within the political economy approach, important contributions include Meins (2003), Bernauer/Meins (2003), and Bernauer (2003). Meins uses rational choice theory, and thus bases her analysis on the assumption that actors have a fixed set of preferences which they pursue through cost-benefit analysis. She also draws on interest group pluralism, which supposes that regulations are the result of competition among interest groups. Bernauer and Meins (2003) and Bernauer (2003) build on this explanation by discussing GM food regulatory differences in terms of the collective action capacity of consumer and producer interests, and of the institutional environment in which regulation takes place. A further study within the political economy 
tradition is Haniotis's article on the Economics of Agricultural Biotechnology (2001). While acknowledging some of the factors mentioned by Meins and Bernauer, Haniotis takes a somewhat different perspective in that he especially stresses the importance of agricultural policy. Although he does not explicitly refer to theory, his conclusions reveal a political economy orientation.

Cultural and belief-based explanations Cultural and belief-based explanations of the transatlantic rift in GM food policy emphasize cultural factors, national styles of regulation, and beliefs to explain policy differences for different food safety laws. For example, Echols's study dealing with food in general suggests that while Europeans trust traditional food practices to ensure food safety, US Americans feel more comfortable when food safety is proven through science. According to Echols, Europeans value limited processing and a link to the land in food, while in the US, consumers have a high regard for change, experimentation, technological innovation, and increased productivity (Echols 1998). In their study of modes of biotechnology assessment in the US, Japan and Denmark, Jamison and Baark seek "to uncover ways in which cultural conditioning of technology takes place" (Jamison/Baark 1990: 31). Epp adds to this approach by emphasizing the importance of the "outcome of interorganizational dynamics" (Epp 2003: 4). She studies the importance of organizations through a constructivist lens, which could be characterized as coproductionist (Jasanoff 2004) in the sense that she develops an "organizationalbased concept of the regulatory process" in which "neither the law nor the organizations it addresses [are] conceptualized as dependent or as independent [variables]" (68).

A growing number of studies drawing on cultural and belief-based explanations can be classified as belonging to science and technology studies, a field that promotes a constructivist understanding of GM food policy and emphasizes the social and cultural meanings underlying policy choices. According to this perspective, GM food policy is socially constructed. Gottweis (1998), Jasanoff (1995), Joly/Marris (2001), Levidow (1999a, 1999b) and Wright (1994) are examples of scholars working within this area. A predominantly sociological, but also constructivist approach is taken by Toke (2004), who pays particular attention to the use of language, as does linguist Cook (2005). 
$\underline{\text { Studies combining both approaches A small category of studies combines }}$ political economy-based and cultural/belief-based approaches, although they usually do so more implicitly than explicitly. One is Vogel (2001) who takes a predominantly political economy approach, but takes into account the role of "civic culture". A further study is provided by Jamison (1987), who analyzes national styles of science and technology in Sweden and Denmark by considering "metaphysical bias", "national scientific interests", and "institutional structures". Some studies on GM foods in trade (e.g. Patterson/Josling 2002) also present a combination of mainly economic, interest-based and, occasionally, cultural explanations for policy differences. They do not go into detail on these explanations, however, since their focus is on discussing implications for trade.

\section{Hypotheses, propositions, results}

Interest-based Scholars who use political economy-based approaches generally formulate hypotheses and propositions revolving around the interests and power of individual or collective actors. The central hypotheses suggested by Meins are that " $[\mathrm{t}]$ he probability of a stringent regulatory outcome is higher when public outrage is present and power is redistributed from producers to consumers", and that "[s]tringent regulations are more likely when public outrage provokes a change in the interests of producer groups (Meins 2003: 35). Meins arrives at the conclusion that stringent regulations "against the preference of a producer group [are] likely when public outrage emerges [...] and when industrial interests align with consumer and environmental interests" (2003: 2). Bernauer reiterates this interest group argument, and further develops the institutional dimension through the concept of "regulatory federalism". He proposes that regulatory stringency depends on "subunit autonomy", which is determined by "the extent to which electorates in states with stricter regulation would tolerate downward harmonization", and "the extent of economic damage that would result from non-agreement" (Bernauer 2003: 104). He concludes that the EU has seen a "ratcheting up" effect, whereas the US has not. Haniotis, on the other hand, maintains that in the US, a combination of trade-oriented changes in farm policy and widespread approval by a variety of actors and groups explain permissive policy. In the EU, in contrast, he suggests that farm policy changes "[point] 
towards the need for output controls, and [do] not provide incentives for commercial applications of GMOs in agriculture" (Haniotis 2001: 176).

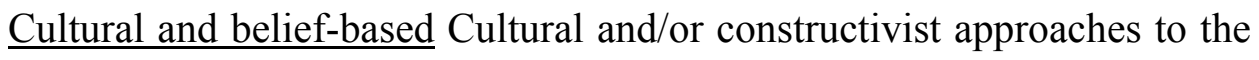
transatlantic rift in GM food policy often do not articulate hypotheses as clearly as studies within the political economy approach do, but rather present propositions or follow an underlying guiding thesis. Rather than setting forth hypotheses and making generalizations, many works within this tradition seek to illuminate the interaction of politics, society and history through detailed narratives. Their unifying, underlying thesis, however, is that beliefs, ideas, national rules, and/or culture shape policies. For example, Echols's main message is that "ideas about food and what may be eaten safely are strongly influenced by local and cultural traditions". Similarly, Levidow argues that the cultural role and meaning of agriculture and the interpretation of risk and the role of science are important factors explaining different GM food regulations (Levidow 1999b).

Jasanoff conducts her analysis of US, UK, and German biotechnology regulation guided by the notion that regulation is "a kind of social contract that specifies the terms under which state and society agree to accept the costs, risks and benefits of a given technological enterprise" (Jasanoff 1995: 311). On this basis, she identifies different "paradigms of control" for US, German and UK biotechnology policies, which differ in their perceptions of physical, social and political risks. In a further study, Jasanoff identifies framing ${ }^{32}$, styles of regulation, the question of what evidence is considered acceptable, different forms of expertise, and the nature of regulatory standards (degrees of flexibility and uniformity) as factors that help explain policy differences in the area of biotechnology (Jasanoff 2000).

In his comparison of three GM food policy case studies (US, EU and UK), Toke finds that three factors "are especially associated with the differences between outcomes in the USA and the EU": different attitudes towards food, different resonances of environmentalist discourses, and the Bovine Spongiform

32 Framing can be understood as a way of implicitly establishing guiding principles and identifying what exists and what matters. It is another term for the concept of "paradigm" developed in this dissertation and used in Chapter 6. Framing often occurs during what policy process theorists describe as "agenda-setting" (Cobb and Elder 1972, Kingdon 1984). 
Encephalopathy (BSE) crisis, also known as "Mad Cow Disease"33 (Toke 2004: 206). He further underlines that "much of what is called science in [the] GM food and crop debate is, in fact, culture" (Toke 2004: 208). Epp conceptualizes regulation as "a social process in which a broad range of actors from various social realms are involved" (Epp 2003: 36). Accordingly, she finds organizations and regulation to be interdependent and "co-explanatory" in the GM food policy debate.

Interest and culture/belief-based In Vogel's view, before the mid-1980s, the US developed more precautionary policies than the EU on issues pertaining to health and the environment (Vogel 2001). According to Vogel, the situation has now reversed. He explains this change towards precaution in Europe through the emergence of a new European "risk-averse civic culture", the growing regulatory role of the EU, and a series of regulatory failures within the EU (e.g. BSE). He explains the US change towards less risk-averse policies through a declining political saliency of consumer and environmental policies, waning political influence of civic interests (e.g. environmental non-governmental organizations, NGOs) since the 1980s, and a lack of the types of regulatory failures that have taken place in the EU.

\subsection{Project relevance}

\section{Empirical relevance}

This dissertation builds on contributions from existing literature in explaining the transatlantic rift in GM food policy by offering an in-depth and systematically comparative analysis that taking into account earlier policy developments, characteristics which are uncommon in studies to date.

Moreover, this research adds to the rapidly developing field of social science-based research on the social and political issues raised by science and new technologies. GM food policy as a research area emerges where science (genetics), technology (genetic engineering), and society (public policy) converge. By studying GM food policy, I generate empirical data on the broader question of how policy-makers address science and new technologies.

\footnotetext{
${ }^{33}$ Relevant events surrounding BSE are related in Chapter 2.
} 
Finally, this study is a contribution to the body of literature comparing EU and US policies in depth. It is not habitual to compare the EU, a union of nation states, with a single nation like the US (albeit with a federalist structure). Most studies relating to the EU and the US are situated in the field of international relations and are not comparative. Many public policy studies comparing the US and Europe pick one or several European countries instead of the EU as case studies. The methodological repercussions of this choice are discussed in Chapter 4.

\section{Theoretical relevance}

Most existing studies of the transatlantic rift in GM food policy choose a political economy and interest-oriented focus or a constructivist and belief-based one. I develop an analytical framework that makes use of approaches containing both interest-based and belief-based elements. Using these approaches together enables me to consider the importance of policy developments preceding the era of GM food, the role of deeply-held beliefs, as well as the levels of success of actors and actor coalitions. The contribution of this dissertation is to attempt to bring these elements together to explain the transatlantic rift in genetically modified food.

\section{Practical relevance}

Differing American and European GM food policies are often perceived as being based on commercial and trade interests alone. As illustrated in parts of the literature review, there is also a tendency to offer a normative assessment of who is "right" and who is "wrong" in the policy debate about GM food. I endeavor to go beyond this type of approach by addressing the reasons for GM food policy differences that are rooted in the politics and polity of the political systems in question. By doing so, like Jasanoff, I hope that "comparative analysis can play a crucial role in making national policy processes more imaginative, self-aware, explicit, and politically responsive" (Jasanoff 2005: 12). This research project develops an analytical framework that can help policy-makers gain a 
better understanding of the issues, which can in turn help prevent transatlantic disputes over GM food policy.

\subsection{Dissertation overview}

This dissertation is organized as follows: Chapter 2 acquaints the reader with introductory information about GM foods and crops. Chapter 3 describes GM food policy in the United States and the European Union, the dependent variable to be explained. Chapter 4 introduces the theory and method underlying this dissertation, as well as the analytical framework developed to analyze and explain GM food policy differences. Chapters 5 to 7 present the empirical analysis and findings of this study. They investigate the propositions presented to explain GM food policy differences: "preceding policies", i.e. policy development during the period of recombinant DNA regulation that preceded GM food regulation (Chapter 5), "paradigms", the world views and beliefs underlying GM food policies (Chapter 6), and "actors and actor coalitions", the way in which different actors and actor coalitions in the GM food debate are able to influence policy outcomes (Chapter 7). Chapter 8 offers a brief summary and concluding remarks. 


\section{GM FOOD IN THE US AND THE EU: OVERVIEW}

\subsection{Overview of GM foods and crops}

In this dissertation, when I refer to genetically modified food or GM food ${ }^{34}$, what is meant are GM crops, or GM foods derived from or containing GM crops $^{35}$ for human consumption. Genetically modified crops and foods are varieties produced by or containing ingredients resulting from genetic transfers between different species. GM crops can mimic aspects of the metabolisms of unrelated species, something not possible in crops resulting from traditional crossbreeding which is possible only within the same species. ${ }^{36}$

GM crops have experienced considerable success since their introduction in 1996. As illustrated by Figure 1, in 1996, the global area of GM crops amounted to 1.7 million hectares. By 2004, this number had grown to 81 million hectares.

${ }^{34}$ Ever since the topic became controversial in the mid to late 1990s, the term "genetically modified food" has been used more readily by EU than US policy-makers. Official US documents tend instead to refer to "bioengineered foods", "foods derived from new plant varieties", "agricultural biotechnology" or "food biotechnology". Further terms frequently used are "genetically engineered" (GE) and "bioengineered". I use the term "genetically modified food" because it is one of the most in use within public debates on the issue, both in the US and the EU.

${ }^{35} \mathrm{GM}$ food can also refer to GM animals such as GM salmon, cows, or pigs. The first GM animal to be commercialized was the so-called "GloFish", a fluorescent red zebrafish sold in the US as a pet since early 2004. In this dissertation, I focus on GM plants (used in food and feed) because they are the most ubiquitous. GM animals are at present much less widespread than GM plants. If this changes, however, they have the potential of becoming even more controversial than GM plants.

${ }^{36}$ In their university textbook on recombinant DNA, Watson et al. explain the difference between traditional plant breeding and plant manipulation through recombinant DNA-technology (the case of GM foods) as follows: "traditional genetic manipulation of plants, practiced for many centuries, is restricted to plants that can sexually hybridize. Recombinant DNA techniques can circumvent these limitations by allowing plant geneticists to identify and clone specific genes for certain traits, such as resistance to an insect pest, and to introduce these genes into already useful varieties of plants. Sexual compatibility becomes irrelevant, and transgenic plants expressing the gene can be selected directly" (Watson et al. 1992: 273). 
Figure 1: GM crops worldwide, 1996-2004

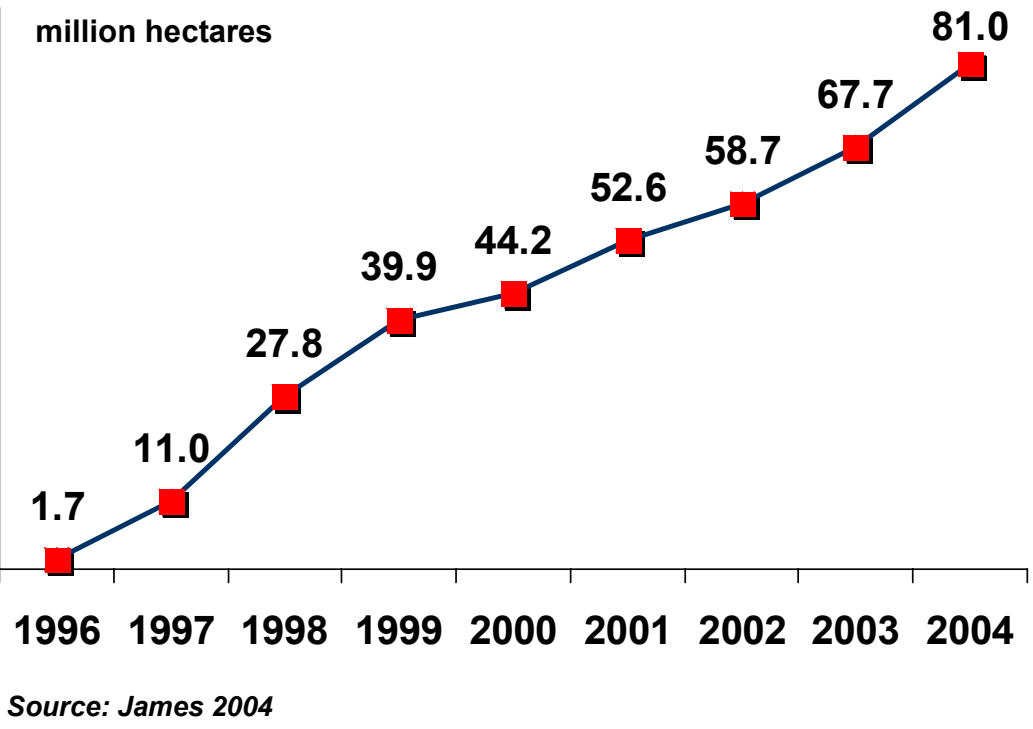

Soybeans (also called soya or soy) have become the most widespread GM crop, accounting for $60 \%$ of global GM crop production and for $56 \%$ of total soybean production (including non-GM soybeans) in 2004. A further important crop is corn (maize in British English), making up 23\% of all GM crops and 14\% of all corn in 2004. Two other large GM crops are cotton and oilseed rape (also know as canola ${ }^{37}$ ) (see Figures 2 and 3).

Figure 2: GM crops by type of crop, 1996 and 2004 (in percent)
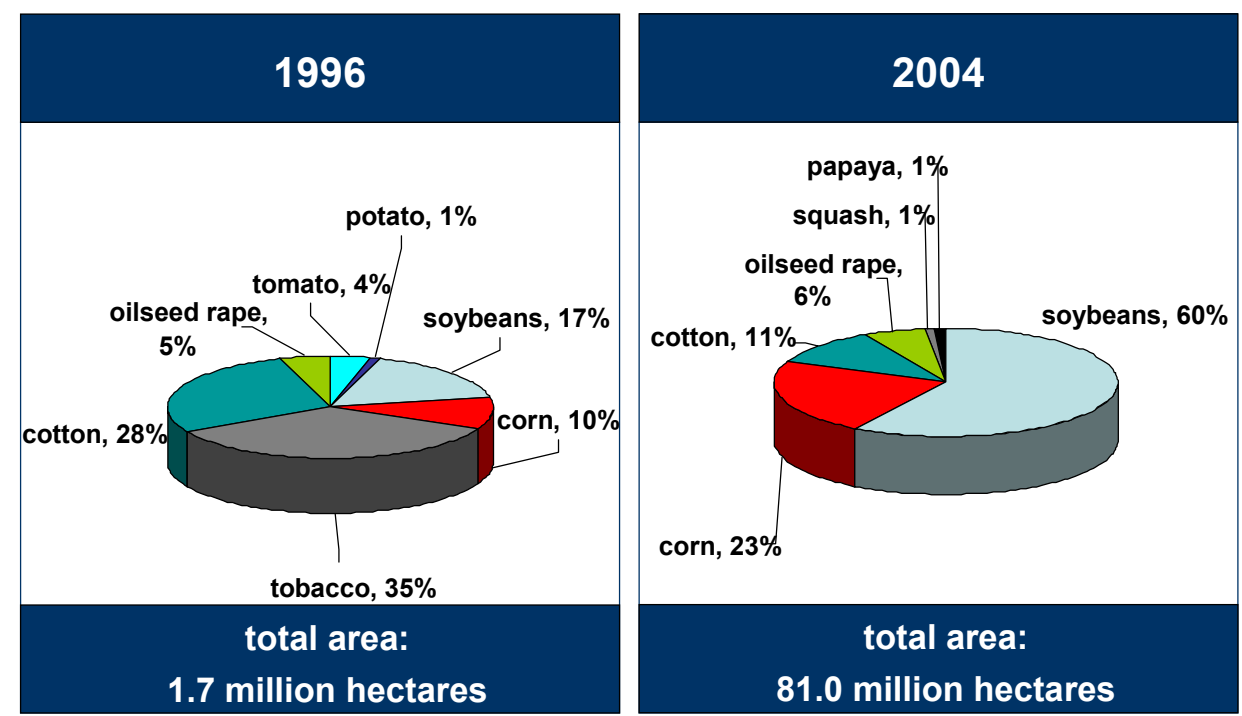

Source: James 1997 and 2004

\footnotetext{
${ }^{37}$ Canola is a variety of oilseed rape originally developed through traditional breeding. The term is often used interchangeably with oilseed rape.
} 
Figure 3: GM crops as a percentage of total crops, 2004
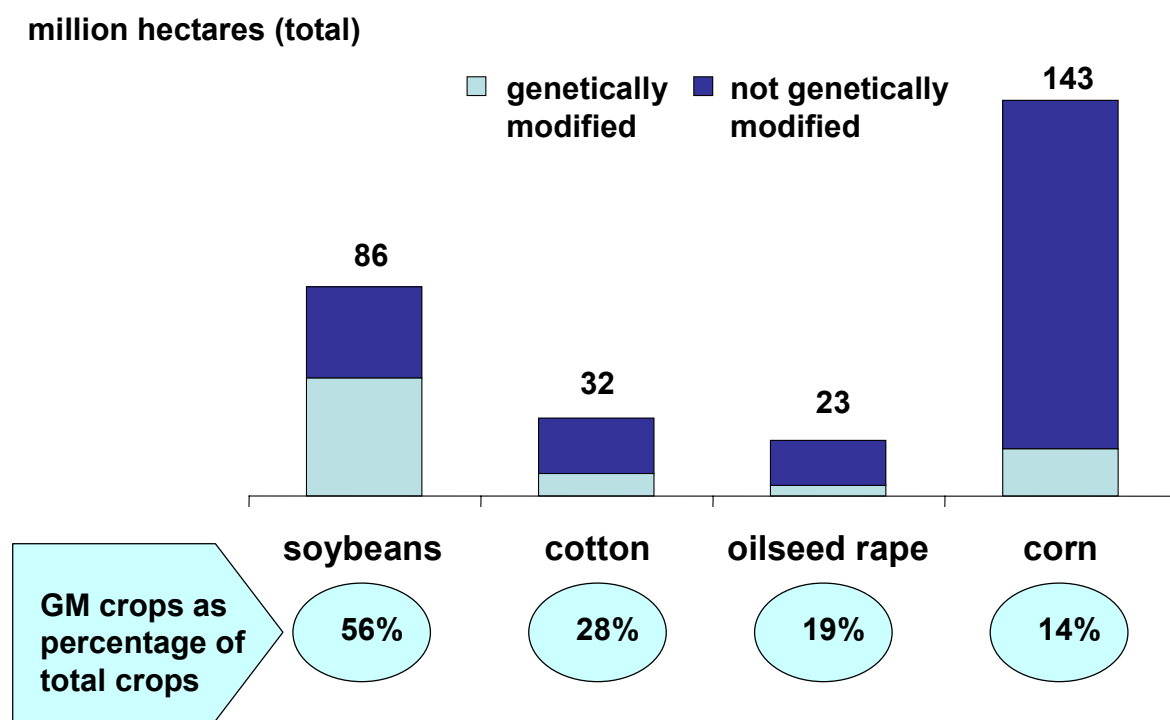

Source: James 2004

In 1997, six countries cultivated GM crops (USA, China, Argentina, Canada, Australia and Mexico). The US accounted for roughly 50\% and China for about $40 \%$ of production. By 2004, the top producing countries were the US (47.6 million hectares or $59 \%$ of total production), Argentina (16.2 million hectares or $20 \%$ of total production), Canada (5.4 million hectares or $6 \%$ of total production) and Brazil (5.0 million hectares or $6 \%$ of total production) (see Figure 4). In 2002, the only producing countries in the European Union were Romania (which was not yet an EU Member State at the time), Spain and Germany, each producing less than 0.1 million hectares. 
Figure 4: GM crop production by country, 1997 and 2004

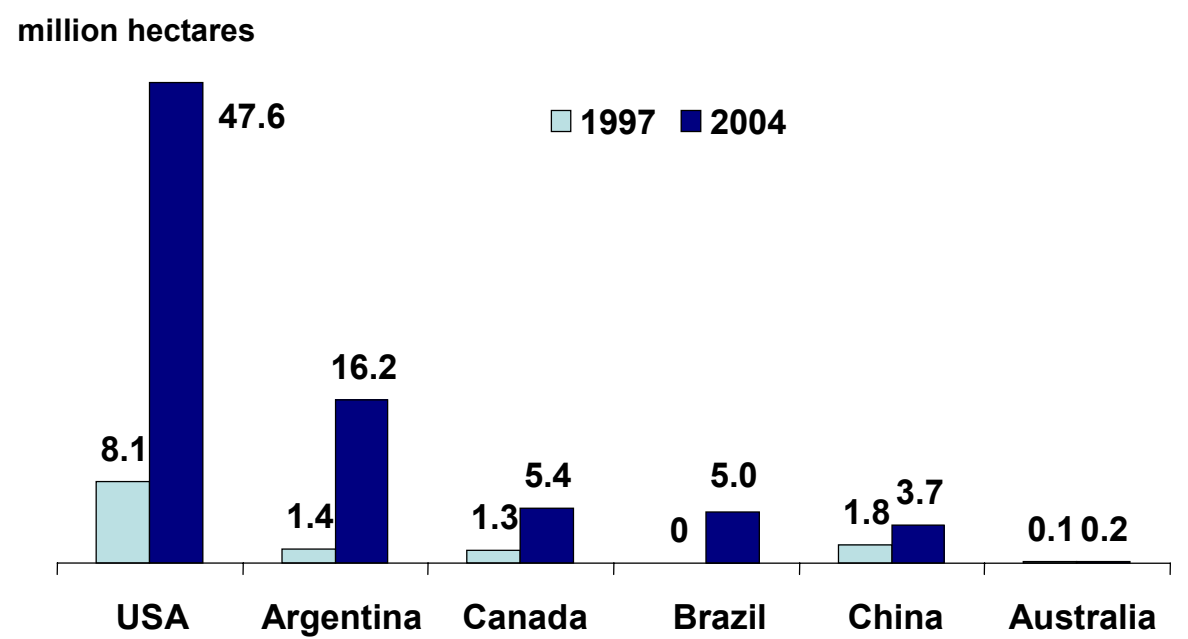

Source: James 1997 and 2004

In 1996, the market for GM seed was worth US\$280 million. By 2004, it had increased 17-fold to US\$4,700 million (ETC Group 2005a). According to some estimates, this represents about one quarter of the commercial (GM and non-GM) seed market worldwide (ibid). The seed market is controlled by about ten companies, the largest of which are US-based Monsanto and DuPont/Pioneer, and the Swiss multinational Syngenta (ETC Group 2005a, 2005b). The company with the largest GM seed market share is Monsanto, estimated to hold between 80 and $88 \%$ of the market; DuPont/Pioneer, Syngenta and Bayer CropScience are the major companies commanding the remaining market share (Rural Advancement Foundation International 2000, ETC Group 2005a).

In terms of traits ${ }^{38}$, herbicide tolerance (resistance to herbicide) is the most common (approximately $71 \%$ of all crops in 2004). ${ }^{39}$ This trait is present especially in soybeans, but also in corn, oilseed rape and cotton. The second most widespread trait is insect resistance (19\% of all crops in 2004), present in socalled "Bt-crops". ${ }^{40}$ Herbicide tolerance and insect resistance can also be

${ }^{38}$ Traits are the qualities that plants are genetically modified to possess.

39 A prominent such trait is tolerance for glyphosate, the active ingredient in the Monsanto Company's widely used herbicide "Roundup". Monsanto has developed a series of glyphosatetolerant or "Roundup Ready" varieties of key crops (soybeans, corn, cotton, oilseed rape).

${ }^{40}$ Bacillus thuringiensis $(\mathrm{Bt})$ is a bacterium that produces crystal proteins (cry proteins) that are toxic to many species of insects that feed on crops, such as the European corn borer and the cotton bollworm. It is used externally as an insecticide in traditional farming. Bt crops are modified with genes from Bt to be able to produce the proteins that are toxic to insects. 
combined ( $9 \%$ of the global area devoted to biotech crops in 2004) (see Figure 5). Taking into account both types of crops grown and GM traits, herbicide tolerant soybeans are the most widespread type of GM crop (60\%), followed by insect resistant corn (14\%) and insect resistant cotton (6\%) (see Figure 6).

Figure 5: GM crops by trait, 1996-2004
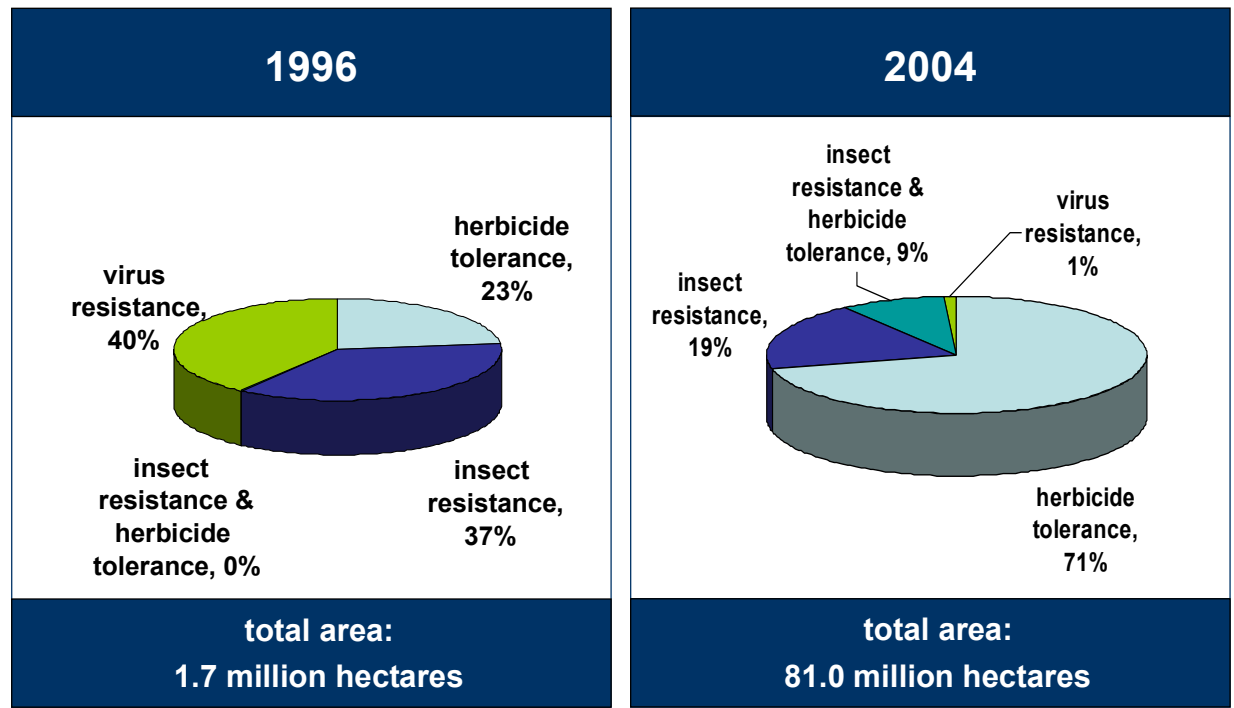

Source: James 1997 and 2004

Figure 6: GM crops by type and trait, 2004

total area: 81 million hectares

IR = insect resistant

$\mathrm{HT}=$ herbicide tolerant

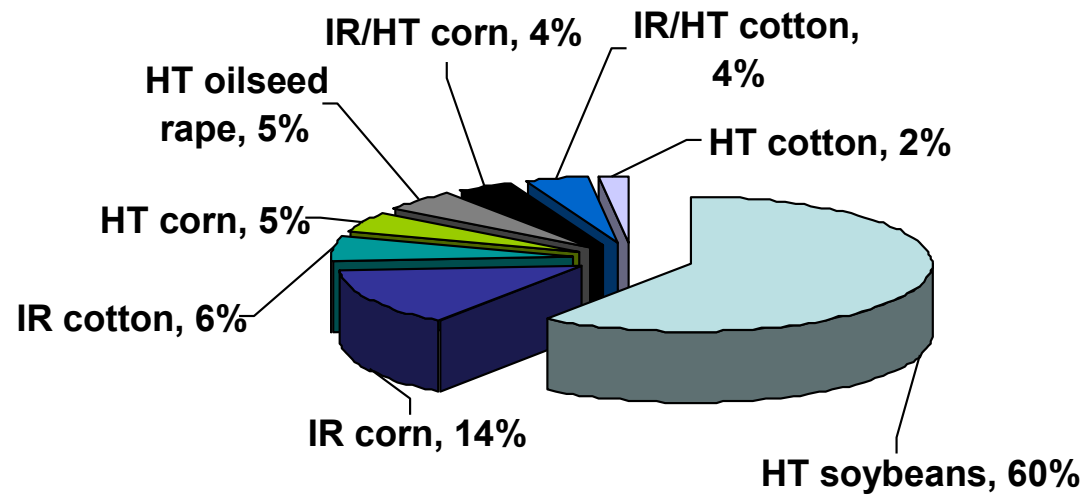

Source: James 2004 
GM foods can be whole foods, such as tomatoes engineered to ripen more slowly than conventional tomatoes, or virus resistant papayas. They can also be foods containing ingredients made with GM crops. Most GM foods on the market are processed foods containing GM food ingredients derived from GM soybeans, corn, cotton or oilseed rape. These crops, especially soybeans and corn, are versatile and ubiquitous, and are used for various industrial purposes, in animal feed and as ingredients in numerous processed foods for human consumption, for example as oils or emulsifiers. Table 1 gives an overview of soy, corn, oilseed rape, and cotton derivatives and their uses in food. These are the processed foods that are potential GM foods.

Table 1: Potential uses of GM crops in food

\begin{tabular}{|l|l|}
\hline \multicolumn{1}{|c|}{ Crop } & \multicolumn{1}{|c|}{ Derivatives, uses in food } \\
\hline Soybeans & $\begin{array}{l}\text { Derivatives: soy lecithin (used as an emulsifier in bakery products, } \\
\text { chocolate, margarine, powdered milk, etc.), soybean oil, soy flour, soy } \\
\text { protein } \\
\text { Examples of processed foods that contain soy derivatives: cereals, tofu, soy } \\
\text { sauce, ice cream, infant formula, sauces, margarine, crackers, breads, } \\
\text { cookies, chocolates, candies, fried foods }\end{array}$ \\
\hline Corn & $\begin{array}{l}\text { Derivatives: corn syrup, corn fructose, corn starch, corn dextrose, corn oil, } \\
\text { corn flour } \\
\text { Examples of processed foods that contain corn derivatives: chips, candy, } \\
\text { ice cream, infant formula, salad dressings, tomato sauces, breads, cookies, } \\
\text { cereals, baking powder, alcohol, vanilla, margarine, soy sauce, powdered } \\
\text { sugar, soft drinks }\end{array}$ \\
\hline Oilseed \\
rape
\end{tabular}

Source: Cummins/Lilliston 2004: 115-116

Since GM foods are not labeled in the US, and since the EU has a labeling threshold of $0.9 \%$ GM content per ingredient, the number of products labeled in each case is not an indicator for how many GM foods are in circulation. Data on how widespread GM foods are in the EU and the US consist of unofficial estimates and lists of products likely to contain GM ingredients compiled by GM food critics. Estimates are based on the fact that roughly $56 \%$ of soybeans and 
$14 \%$ of corn grown worldwide are GM varieties (James 2004), and that these are widely used by the food industry in processed foods.

It is generally estimated that 60 to $75 \%$ of all processed foods in the US contain GM ingredients (Cummins/Lilliston 2004: 5). This estimate has remained more or less stable since GM foods entered the US food production chain. For the EU, even estimates are hard to find. Before EU consumers and, as a result, many supermarkets rejected GM foods in the late 1990s, the number of GM foods available was probably similar (or somewhat smaller) since the United States was and remains a main source of soybeans and corn for the European Union. With the adoption in 2000 of European Commission Regulations (Regs.) 49/2000 and $50 / 2000$, labeling and thresholds rules for GM content were introduced for the first time (European Commission 2000a, 2000b). It is plausible that as a result levels of GM content sank somewhat, although many processed foods probably retained a GM content under the $1 \%$ threshold in force at the time.

Before the new labeling regulations came into force on 18 April 2004, spot checks by consumer associations, environmental groups and the media discovered both authorized (under the 1\% threshold) and unauthorized GM content in food. Most of the studies conducted found about $30 \%$ of their samples to contain such material. For example, Stiftung Warentest, Germany's foremost consumers association, detected GM content of up to $20 \%$ in 31 out of 82 unlabelled products ("Biss ins Ungewisse" 2000). A further example was a test conducted in 2002 by La Repubblica, one of Italy's main national newspapers. Out of 31 products tested in the Turin area, ten contained GM ingredients, including four with very high content levels. Two of these products were labeled "organic", which in theory precludes a product being genetically modified, and in another product, a type of corn was found that was not authorized in Europe (Piervincenzi 2002). A third example is a study conducted by the French Institut national de la consummation in 2002. Like the German and Italian studies, this study found about one third of the products it tested to contain GMOs (36 out of 103) (“OGM: la contamination” 2002).

According to some consumer associations and other GM food observers, these numbers seem to have decreased after 2004, when new labeling rules came into force (e.g. Transgen 2005b). Not only have the new rules lowered the per- 
ingredient-threshold to $0.9 \%$, but labeling is now obligatory even if GM ingredients can no longer be detected in the end product. The implementation of this rule is based on traceability requirements. Multinational food producers such as Kellogg's, Kraft, McDonald's and Nestlé have had to find ways to work with or around these new rules in Europe, while they could continue to use GM food ingredients in the US. Some food producers secured sources of non-GM food ingredients. However, since this is costly and difficult to ensure, many food companied have instead reformulated the recipes of their products, avoiding GM ingredients or staying under the legal $0.9 \%$ threshold per ingredient.

Greenpeace International's "Trolley Watch", consisting of a campaign encouraging EU citizens to photograph labeled GM foods on supermarket shelves and send them to the Greenpeace website, has received reports of around 70 labeled GM foods, examples of which are listed in Table 2 (Greenpeace International Trolley Watch. GE Food in Europe).

Table 2: Examples of labeled GM foods in the EU

\begin{tabular}{|l|l|}
\hline Soy sauce & candy bars \\
soybean paste & baking mixes \\
soybean sprouts & Cookies \\
Tofu & Syrup \\
Dressings / sauces / toppings & food coloring \\
vegetable oil & Popcorn \\
Margarine & root beer \\
\hline
\end{tabular}

Source: (Greenpeace International Trolley Watch.GE Food in Europe)

\subsection{The pros and cons of agricultural biotechnology}

GM foods and crops are controversial because they raise a series of issues pertaining to consumer and animal health, the environment, socioeconomic aspects, and ethics. Table 3 at the end of this section provides a summary of the arguments most frequently used by GM food supporters and critics. ${ }^{41}$

A first area of controversy is human and animal health. GM food proponents underline that, so far, no health problems have emerged in connection

${ }^{41}$ An excellent and complete discussion of health, environmental, socioeconomic and ethical aspects is provided by the Nuffield Council on Bioethics (1999). 
with GM food, and that they are very unlikely to do so. They also foresee a "second generation" of GM food products which will bring health benefits for consumers, including improved nutritional value, taste, longer shelf-life and wider product choice. Critics, on the other hand, are of the opinion that agricultural biotechnology brings no tangible benefits to consumers. Instead, they emphasize the potential health hazards that GM food might cause, in particular food allergies and resistance to antibiotics through the insertion of antibiotic resistance markers $(\mathrm{ARM})^{42}$ into $\mathrm{GM}$ foods.

The environment is an additional area of contention for agricultural biotechnology. GM food supporters maintain that GM crops enable the effective control of pests and weeds while at the same time reducing the need for tillage ${ }^{43}$ and therefore soil damage and erosion. Another argument for proponents is that GM crops reduce the use of pesticides, especially herbicides and insecticides. Insect resistant crops are specifically modified to resist pests and therefore no longer require as much conventional insecticide. Herbicide tolerant plants are modified to resist the use of glyphosate, a relatively benign herbicide in comparison with certain other available products. According to proponents, farmers using glyphosate resistant crops also use less glyphosate than they would if they were growing non-GM crops. GM food and crops critics call these claims into question, stating ambiguous results as to reduced pesticide use. In addition, they fear the development of weeds ("superweeds") and insects that are resistant to pesticides. They further warn against "genetic contamination" or "genetic pollution" of other species if GM plants spread through pollen and seeds in an uncontrolled manner. This in turn threatens the ecosystem and biodiversity.

Socioeconomic issues are a further aspect of the GM food debate. GM food proponents not only emphasize reduced production costs thanks to GM crops, but also suggest that genetic engineering can help solve the problems of developing countries, for example if drought-resistant crops were developed. Anti-GM food voices, on the other hand, denounce agricultural biotechnology

\footnotetext{
${ }^{42}$ In the genetic engineering of plants, antibiotic resistance markers (ARM) are often transferred together with the desired gene because they enable the detection of that gene in the engineered plant. Antibiotic resistance markers thus help determine if genetic engineering was successful. Since these markers are resistant to certain antibiotics, GM food critics feat that they might cause resistance to antibiotics in humans and animals.

${ }^{43}$ Tillage refers to the mechanical preparation of soil for planting of seeds. It involves destroying weeds and loosening soil, which can lead to erosion.
} 
companies for introducing products that promote agribusiness and monoculture, thus threatening traditional farming methods. They underline that the GM seed market is controlled by a few multinationals which can set prices as they wish. To the suggestion that GM crops can solve world hunger, critics counter that the developing world needs different kinds of help than agricultural biotechnology, leading to sustainable solutions that would not make them dependent on industrialized countries. They contend that GM food proponents exploit the idea of helping nations in need of food aid for the sake of publicity.

Many of the ethical considerations under discussion are closely related to socioeconomic issues, and some address legal questions. For GM food proponents, genetic engineering is a natural extension of traditional plant breeding, and is therefore nothing unnatural or ethically objectionable. At the same time, GM food supporters believe that developers of agricultural biotechnology should be granted intellectual property rights and be able to patent GM products. In this perspective, it is right for biotechnology companies to make profits from the applications they develop since they have invested heavily in them. In contrast, to many opponents of GM foods, genetic engineering is wrong because it is unnatural and means "playing God" or manipulating life. They view property rights on any kind of plant as exploitation of nature and life itself- They strongly believe that ownership of plant technologies and patents should not be permitted. 
Table 3: The pros and cons of agricultural biotechnology

\begin{tabular}{|c|c|c|}
\hline & $\begin{array}{l}\text { Arguments in favor } \\
\text { of GM foods and crops }\end{array}$ & $\begin{array}{l}\text { Arguments against } \\
\text { GM foods and crops }\end{array}$ \\
\hline $\begin{array}{l}\text { Human and } \\
\text { animal health }\end{array}$ & $\begin{array}{l}\text { - no proven risks for human or } \\
\text { animal health } \\
\text { - future consumer benefits ( } 2^{\text {nd }} \\
\text { generation products): } \\
\text { - improved nutritional value } \\
\text { - } \quad \text { improved taste } \\
\text { - } \quad \text { longer shelf life } \\
\text { - } \quad \text { wider choice of food } \\
\quad \text { products }\end{array}$ & $\begin{array}{l}\text { - } \text { potential human and animal } \\
\text { health hazards: } \\
\text { - } \quad \text { resistance to antibiotics } \\
\text { - potential allergies } \\
\text { - no significant consumer benefits }\end{array}$ \\
\hline Environment & $\begin{array}{l}\text { - effective control of pests and } \\
\text { weeds } \\
\text { - less tillage needed (soil damage } \\
\text { minimized) } \\
\text { - reduced use of pesticides } \\
\text { - the type of pesticide used } \\
\text { (glyphosate) is relatively benign }\end{array}$ & $\begin{array}{l}\text { - use of GM crops leads to insect } \\
\text { and weed resistance to pesticides } \\
\text { - genetic "contamination" or } \\
\text { "pollution" through pollen/seeds } \\
\text { - changes in the ecosystem } \\
\text { - threat to biodiversity }\end{array}$ \\
\hline $\begin{array}{l}\text { Socioeconomic } \\
\text { issues }\end{array}$ & $\begin{array}{l}\text { - agricultural costs of production } \\
\text { (e.g. labor) reduced } \\
\text { - } \text { solution of world hunger through } \\
\text { new varieties (e.g. drought } \\
\text { resistant crops) } \\
\text { - enhanced food supply worldwide }\end{array}$ & $\begin{array}{l}\text { - agribusiness and monoculture; } \\
\text { threat to traditional farming } \\
\text { GM seed market controlled by } \\
\text { few multinationals, price } \\
\text { manipulation possible } \\
\text { - dependence of developing } \\
\text { countries on technologies which } \\
\text { they cannot afford }\end{array}$ \\
\hline $\begin{array}{l}\text { Ethical and legal } \\
\text { considerations }\end{array}$ & $\begin{array}{l}\text { - genetic engineering is an } \\
\text { extension of traditional breeding } \\
\text { - successful private investment } \\
\text { should lead to profit }\end{array}$ & $\begin{array}{l}\text { - genetic engineering is unnatural } \\
\text { and means "playing God" } \\
\text { - private ownership in this area } \\
\text { means exploiting life itself }\end{array}$ \\
\hline
\end{tabular}

\subsection{GM food and its regulation in the US and the EU: chronological overview ${ }^{44}$}

\section{United States}

\section{3-1991: From rDNA technology to GM crop field trials A first of} three main phases in the development and regulation of GM foods and crops in the US runs from 1973, when rDNA technology became possible, to 1991, when

${ }^{44}$ Further details on the events covered and policy documents mentioned in this chronology will be given later in this dissertation. The goal of this section is to give a brief chronological overview of events relevant to the GM food debate. 
first GM foods and crops were being tested in field experiments and would soon hit the US market. Key events during this phase were the 1973 announcement of rDNA technology as a new tool of molecular biology, the Asilomar conference in 1975 leading to the 1976 National Institutes of Health (NIH) Guidelines on rDNA research, and the publication of the Coordinated Framework in 1986 (Office of Science and Technology Policy 1986). The Coordinated Framework represents a key turning point during this phase as it determined fundamental regulatory principles that guide US policy to this day.

In 1973, scientists Stanley Cohen and Herbert Boyer developed the technology necessary to genetically modify DNA. This scientific event marked the beginning of what would become the debate on recombinant DNA in the 1970s, and, later, on GM food in the 1990s. It led to a temporary moratorium on certain experiments with recombinant DNA and to a famous conference, the 1975 "Asilomar Conference", on how best to address the possible hazards of such research. This in turn triggered the development, in 1976, of the first National Institutes of Health (NIH) Guidelines for Research Involving Recombinant DNA Molecules (National Institutes of Health 1976). As scientists gained experience with the new technology, and as the public debate on the issue slowly abated, these fairly restrictive rules were relaxed.

By the late 1970s and early 1980s, it became clear that first applications of rDNA technology were "in the pipeline". The White House's Office of Science and Technology Policy (OSTP), dominated by President Ronald Reagan's "no new law" mantra, responded to the impending possibility of both state and national legislation by drafting the Coordinated Framework for Regulation of Biotechnology ("Coordinated Framework" for short), which was announced in 1986 (Office of Science and Technology Policy 1986).

The driving principle developed with the 1986 Coordinated Framework has not changed since the 1980s: GM crops and foods are regulated as end products that are not to be treated any differently from non-GM foods and crops because of their process of production. ${ }^{45}$ The Framework further provided a

${ }^{45}$ As will be discussed elsewhere in this dissertation, this principle resulted from an institutional struggle between the Environmental Protection Agency, which favored a more process-based and precautionary approach, and the US Department of Agriculture's Animal and Plant Health Inspection Services, which, supported by the White House, supported a product-based approach 
structure for the oversight of modern biotechnology that did not necessitate new laws because existing legislation in the areas of agriculture, food and drugs was sufficient. It determined which existing federal agencies were able to regulate what types of biotechnology under which existing statutes (or laws). Agricultural biotechnology fell under the responsibility of the Animal and Plant Health Inspection Services (APHIS), the Environmental Protection Agency (EPA) and the Food and Drug Administration (FDA). The designated agencies drafted their first policy guidelines and rules in 1986, at the same time as the Coordinated Framework was announced.

APHIS was the quickest to specify its rules since it was in charge of overseeing field tests with GM plants for which authorizations were being requested. In 1987, APHIS began issuing so-called "permits" for field tests with GM crops. From the late 1980s to the early 1990s, Monsanto and other corporations were hard at work developing first applications of rDNA research in the field of agriculture.

1992-1996: GM foods and crops enter the marketplace A second, relatively short, phase in the development and regulation of GM foods and crops in the US runs from 1992 to 1996, and covers the introduction of first agricultural biotechnology products onto the market. 1992 saw the approval of the first GM food, whereas 1996 is the year when GM crops were first planted, harvested, and exported. 1996 can be seen as a turning point, since this is when consumers worldwide first began to take notice of the phenomenon of GM foods and crops. Late 1996 is when the development of public rejection of agricultural biotechnology has its roots, especially in Europe, and, in the form of a backlash somewhat later, also in the United States.

Not until the early 1990s did US federal agencies begin to develop procedures and policies for commercializing first GM plants. The Flavr Savr tomato, the first GM food to be marketed in the United States, jumpstarted regulatory activity on GM foods and crops for the commercial market. Developed by a small Californian biotechnology company named Calgene, the Flavr Savr tomato was genetically modified to delay ripening, the idea being that it could 
remain on the vine longer before being harvested, thus enabling a better tasting tomato on supermarket shelves. In 1992, APHIS granted the Flavr Savr so-called "nonregulated status", which meant that it could be grown commercially without further oversight.

That same year, prompted by Calgene's 1991 application to market the Flavr Savr tomato, FDA developed its Statement of Policy on Foods Derived from New Plant Varieties (Food and Drug Administration 1992). Central to this document, which remains the agency's main policy document on GM food, is the principle that FDA treats GM foods just like any other foods, and that therefore no specific authorization procedure or labeling is necessary. The Flavr Savr tomato was approved in 1994 by FDA and sold in some parts of the US between 1994 and 1998. Its commercial failure was not connected to its being genetically engineered (GE). Instead, the main trouble was Calgene's lack of experience with tomato breeding and marketing. In addition, the Flavr Savr tomato bruised easily and did not "save as much flavor" as hoped. Calgene was acquired by Monsanto in $1997{ }^{46}$

In 1994, a second GM tomato made its way onto the US market. British biotechnology company Zeneca initiated and completed an FDA consultation on another tomato, modified, like the Flavr Savr tomato, to ripen more slowly. This GM tomato was also ideal for industrial processing because it was engineered to have a firmer, less watery texture than non-GM tomatoes. In the US, this tomato was sold in the form of a puree by Safeway from 1996 and until 1999, when Zeneca discontinued production for reasons explained below under the EU chronology in this chapter.

In the late 1980s and early 1990s, while Calgene experimented with GM tomatoes, other biotechnology companies were developing GM crop varieties such as GM soybeans, corn and cotton. In 1993, APHIS introduced a streamlined "notification" procedure to approve field tests, which was extended to most varieties in 1997. In 1994, EPA began the process of adopting rules to regulate the Bacillus thuringiensis $(\mathrm{Bt})$ toxin in certain GM crops as pesticides, renamed "plant-incorporated protectants" (PIPs) in 2001. First GM soybean and corn

\footnotetext{
${ }^{46}$ Charles 2001 (chapter 10) and Martineau 2001 offer detailed accounts of the story of the Flavr
} Savr tomato. 
varieties were approved in 1995, and FDA issued an informal guidance document on consultation procedures regarding GM products in 1997 (Food and Drug Administration 1997). GM soybean and corn varieties were sold to US farmers, planted, and harvested commercially in the United States for the first time in 1996. They made their way into US animal feed and processed foods for human consumption practically unnoticed by the general public despite some campaigns by environmental and consumer groups.

1997-2005: Mounting public attention and regulatory stability A third phase in the development and regulation of GM food began in 1997 and continues to the time of writing. It covers a period of mounting public attention and, in some cases, concern regarding agricultural biotechnology, which is at the same time characterized by a remarkable regulatory stability. Key events during this period are crises revolving around the monarch butterfly (1999) and StarLink (2000).

US Americans' attention regarding GM foods and crops was first awakened by Europeans' negative reaction to first GM grain shipments entering European ports in late 1996 and early 1997. However, concern with GM foods never was and never became a mainstream phenomenon in the US. There were some misgivings, mainly on the part of environmental activists, about the socalled "terminator" technology, for which the US Department of Agriculture and the Delta and Pine Land Company, a major cotton and soybean breeder, received the first patent in March 1998. This technology, entitled "Control of Plant Gene Expression", was meant to prevent unwanted germination of the seeds produced by GM crops, thereby controlling the unwanted spread of GM crops into the environment. GM food critics, however, saw the technology as a threat to the livelihood of farmers, especially in the developing world, who depend on saving and replanting seed. ${ }^{47}$ It also was denounced as a tool devised entirely to increase corporations' profits. What aroused worldwide attention, however, were Monsanto's plans to commercialize this "terminator gene". The public uproar, in

\footnotetext{
${ }^{47}$ In the opinion of some US farmers supporting agricultural biotechnology, this is not a convincing argument, at least for farming in the industrialized world. As Hayden Milberg of the National Corn Growers Association explains for the case of corn, "with [non-GM] modern hybrid varieties, it is not possible to save corn seed and get the same yield the following harvest"; this means that farmers buy new seed every year, whether it is GM seed or not (interview with Hayden Milberg, National Corn Growers Association, 9 June 2004, Washington, DC).
} 
the US and especially in Europe, was such that Monsanto renounced its plans in October 1999.

The first event that alerted a wider circle of US Americans to possible negative consequences of GM food production was the publication, in May 1999, of a scientific article suggesting that the well-loved and beautiful monarch butterfly might be harmed by GM crops. More specifically, an entomologist at Cornell University published a paper in Nature reporting laboratory experiments that showed that $44 \%$ of monarch butterfly larvae had died four days after eating milkweed plants ${ }^{48}$ dusted with pollen from Bt corn, whereas larvae exposed to conventional corn pollen had not (Pew Initiative on Food and Biotechnology 2002: 8). The monarch butterfly study met with immediate interest from advocacy groups, which alerted the media, leading to reports that captured public attention. In subsequent years, further research into the effects of Bt corn on the monarch butterfly was conducted, spurred by new data requirements issued by EPA, which had to consider whether to grant new authorizations for several Bt corn varieties. The test results showed that most Bt corn pollen was not harmful to the monarch butterfly, except for the pollen of Bt176, an insect resistant corn variety manufactured by Novartis (now Syngenta) and with a registration due to expire in April 2001. EPA let the registration for Bt176 expire, and, in October 2001, renewed authorizations for the five other Bt corn varieties that were already on the market. Public interest in the issue died down.

Over a year after the publication of the article on the monarch butterfly, another event occurred which had a somewhat more lasting impact. In September 2000, the Washington Post, a major US newspaper, reported that Genetically Engineered Food Alert, a coalition of anti-GM activists, had ordered a series of tests on processed foods, which revealed traces of StarLink corn in taco shells manufactured by Kraft Foods. StarLink corn is the trademark for a Bt corn variety that produces its owns pesticide (Cry9C). StarLink corn, produced by Aventis CropScience (Bayer CropScience since 2002), had been approved in 1998 by EPA for use in feed, but not for use in food because allergic reactions in humans were considered possible, although unlikely.

\footnotetext{
${ }^{48}$ Milkweed is a source of nutrition for monarch butterfly larvae, and both milkweed and monarch butterflies are found in and around cornfields.
} 
Kraft voluntarily recalled all its taco shells; Aventis halted grain sales and took StarLink corn off the market. After the September 2000 discovery, some consumers reported allergic reactions as a result of consuming taco shells, but none of these reactions were subsequently confirmed as resulting from StarLink corn. Aventis quickly agreed with the federal government to purchase all StarLink corn from farmers, ensuring that it would be used only in feed and for industrial purposes. This deal cost Aventis at least US\$100 million according to some sources (Segarra/Rawson 2001: 4), if not more - the media widely reported a cost of US\$1 billion. Other actors that suffered from the affair were grain processors and food producers, who were partly reimbursed by Aventis. EPA made the decision to avoid "split authorizations" in the future, defined as authorizations for only feed, but not for food. As in the case of the monarch butterfly, the public gradually lost interest in the StarLink case, satisfied that regulators and industry had dealt with the crisis adequately.

In late 2002, another "StarLink-type" crisis was averted when APHIS discovered soybeans destined to be used in food and feed that had been mixed with GM corn designed to produce pharmaceuticals (plant-made pharmaceuticals or PMPs). APHIS had begun authorizing field trials with PMP-producing GM plants in 2001, and one of the provisions attached to this type of test was strict segregation from GM crops to be used in food and feed. In September and November 2002, during routine tests, APHIS found traces of a pharmaceuticalproducing corn in a soybean field in Iowa. The corn had previously been grown in a field trial in the same location as the soybeans. In a similar case in Nebraska, discovered in November 2002, the "contaminated" soybeans had already been harvested, transported to an elevator, and combined with other soybeans. In both cases, ProdiGene, a small Texan biotechnology company specialized in developing PMPs or "biopharming", had failed to take adequate measures to destroy the PMP-producing corn following the 2001 field trials. ProdiGene was fined US $\$ 500,000$ by APHIS for negligence and agreed to buy back the 500,000 bushels of "contaminated" soybeans (valued at US\$2.7 million) to be destroyed or diverted to feed or non-food usage such as the production of biofuel (fuel made from plants). In March 2003, APHIS announced proposed rules for PMPproducing crops, which are stricter than rules for GM crops that do not produce PMPs (Animal and Plant Health Inspection Service 2003). 
In the spring of 2005 , the latest incident involving agricultural biotechnology had transatlantic repercussions when US grain exporters inadvertently sent several hundred tons of an unauthorized GM crop (Bt10 corn) to the EU instead of the authorized Bt11 variety. Unlike Bt11, the Bt10 strain has a gene that is resistant to the animal antibiotic ampicillin. It turned out that its producer, Syngenta, had mistakenly sold Bt10 grain to US farmers between 2001 and 2004 although this strain was not approved for distribution. As a response to the mixup, in April 2005, EU Member States adopted a measure requiring imports of Bt11 corn to be certified as Bt10 free, and the US Department of Agriculture required Syngenta to pay a US\$US 375.000 fine.

\section{European Union}

1973-1990: From discussions on rDNA technology to Directive 90/220 As in the case of the US, the debate on and regulation of GM foods and crops can be described in three phases. The first of these phases covers the time period from 1973 to 1990 , beginning with the news of rDNA technology as a new method and ending with the adoption of Council Directive (Dir.) 90/220 (Council of the European Union 1990b), the EU's first piece of legislation on GMOs. Key events during this period were the 1973 announcement on rDNA technology in the US, the 1982 approval of Recommendation by the Council of the European Union ("Council of the EU", "Council") on rDNA research (Council of the European Union 1982), and the passage of the 1990 Council Directive on the deliberate release of GMOs into the environment (Council of the European Union 1990b). This event constituted a turning point from a relatively permissive EC policy on rDNA research to a relatively restrictive policy on its applications.

The 1973 news that US scientists had developed new rDNA technologies impelled European scientists to catch up with US advances in science and technology. Convinced of this necessity by the scientific community, the European Community (EC) and individual European governments were therefore not particularly inclined towards stringent new rules hindering scientific research. Most European countries devised rules that were modeled on the guidelines developed in the US and in the United Kingdom (UK). In addition, the European Community drafted a directive on rDNA research as of 1978, only to withdraw it 
and then pass it as non-binding recommendation in 1982 (Council of the European Union 1982). During this phase of searching for ways to regulate rDNA research, scientists were the main group to influence guidelines and regulation on scientific questions.

The rise of environmentalism and growth of political parties and interest groups with environmental agendas as of the mid-1980s brought with it a more complex attitude towards biotechnology. An environmental or "green" outlook on biotechnology became more and more widespread, and genetic engineering began to be perceived as a potential threat to the environment. It was in this context and climate that the genetically modified organisms dossier came to be dealt with by the European Commission's ("Commission") Environment Directorate-General (DG) instead of DG Research, which had dealt with rDNA research in the 1970s and early 1980s.

Accordingly, the EC's first directives on GMOs, passed in 1990, had an environmental focus. Council Directive 90/219 (Council of the European Union 1990a) on the contained use of GMOs and Council Directive 90/220 (Council of the European Union 1990b) on their deliberate release into the environment were based on a process-based logic, that is, the idea that GMOs should be regulated in a certain way because they were produced through a certain process. The biotechnology industry lobby in Brussels had reluctantly accepted the deliberate release directive in order to be able to more forward with new product approvals. There was a general feeling at this time that European harmonization on environmental issues was a necessary step towards further European integration. As soon as Directive 90/220 was passed, however, it was attacked by the biotechnology industry, which denounced its process-based logic as being unscientific, and accused it of being a potential hindrance to European research and development.

1991-1999: from first authorizations to crisis A second phase in the regulation and development of GM foods and crops essentially covers the 1990s, during which the EU approved a series of agricultural biotechnology products, and ends in 1999 with the EU Council's de facto moratorium on the approval of any new GMOs or GM products. Key events during this phase are numerous. They include the arrival of first GM corn and soybean shipments from the US in 
European ports (1996), the eruption of the BSE scandal (1996), the putting in place of the Novel Foods Regulation (Reg.) (1997), the news of the birth of the cloned sheep Dolly (1997), and the declaration of the de facto moratorium by several EU Member States (1999). Of these, the arrival of GM crop shipments and the declaration of the moratorium can be seen as major turning points. The former of these events introduced the GM food era in Europe, while the latter event put a sudden halt to approvals only three years later.

During the first half of the 1990s, the only GMOs authorized under 90/220 were vaccines and one variety of tobacco. In 1995, the UK Advisory Committee on Novel Foods and Processes (ACNFP) approved Zeneca's tomato modified to delay ripening, referred to above. Since this tomato was grown only in California, it did not require approval under Directive 90/220, which did not cover foods produced from GMOs. In the UK, the tomato was sold as puree by Sainsbury's as of February 1996, voluntarily labeled as a GM food. The GM food tomato puree sold well, perhaps helped along in the UK by the fact that it was sold at a price slightly more advantageous than that of puree made from conventional tomatoes. Zeneca even planned to market and grow the whole tomato in Europe. Indeed, in 1996, public rejection of GM foods was not yet as widespread a European sentiment as it would become a few years later, especially in the UK. ${ }^{49}$

On 20 March 1996, about a month after the first GM tomato puree went on sale, the Bovine Spongiform Encephalopathy $(\mathrm{BSE})^{50}$ scandal took center stage when the UK Government announced a suspected link between BSE and variant Creutzfeldt-Jakob disease (vCJD). Variant Creutzfeldt-Jakob disease is the human equivalent of BSE, as fatal to humans as BSE is to cattle. Although BSE had nothing to do with genetic engineering, the ensuing food safety, public

\footnotetext{
${ }^{49}$ Sainsbury withdrew its GM tomato puree from the market in 1999, when public opinion had become an obstacle for its successful sale. Bernard Graciet, who worked for Zeneca at this time, explains why the GM tomato puree was taken off the market from the company's perspective: "[Zeneca] stopped production for two reasons. First, supermarkets (not consumers) no longer wanted the puree. Second, and most importantly, we could not get the approval to grow GM tomatoes in Europe, and importing them from California was too expensive. Those were our reasons for withdrawing our notification from the European Commission" (interview with Bernard Graciet, Syngenta, 15 September 2004, Brussels).

${ }^{50}$ Bovine Spongiform Encephalopathy is one of several diseases categorized as Transmissible Spongiform Encephalopathies (TSEs), and is a fatal animal disease affecting the cattle's brains. Isolated cases of BSE probably existed long before 1986.
} 
health and regulatory crisis, at both the UK and EU levels, profoundly influenced European consumers' inclination to accept the GM crops that would be planted and harvested for the first time that very year in the United States and would arrive shortly after in Europe for the first time in the form of grain shipments. European Commission attempts to reassure the public, for example with the 2000 White Paper on Food Safety, came too late to avert the crisis (European Commission 2000c).

Backing up to the early years of this crisis, BSE, often referred to as "mad cow disease", had first been diagnosed in 1986 in cattle in the United Kingdom. As a result, the UK government had then banned the use of cattle feed containing bone meal, ${ }^{51}$ and had ordered the slaughter of all cattle diagnosed with BSE. In the context of steadily increasing numbers of BSE cases, scientists were finding increasing evidence that BSE might be transmissible to humans. As late as the early 1990s, however, the UK government excluded the possibility of a human version of BSE, and declared that British beef was safe to eat. As a demonstration, in 1990, Agriculture Minister John Gummer and his daughter ate beef burgers in front of the British press as a gesture to calm rising panic over the safety of British beef.

Even after Creutzfeldt-Jakob disease (CJD) was diagnosed in three very young patients in $1995,{ }^{52} \mathrm{UK}$ government scientists continued to reject the possibility that BSE could be transferred to humans. Only on 8 March 1996 did the UK's National CJD surveillance unit suggest that a new form of CJD, which would became known as $\mathrm{VCJD}$, had been identified in a group of unusually young people. On 20 March 1996, the UK government announced that the most likely explanation for these cases was exposure to BSE. As a response, on 27 March 1996, the European Commission imposed a worldwide export ban on British beef and beef products.

51 The UK epidemic is thought to have been caused by commercial cattle feed concentrates containing meat and bone meal derived from sheep and possibly cattle infected with scrapie, a type of TSE.

${ }^{52}$ Creutzfeldt-Jakob disease (CJD) is a rare fatal brain disorder which usually affects about one in one million people per year worldwide, and which usually appears in later life. The fact that the patients were young was therefore a sign that the disease diagnosed was a new variant of CJD. This new human variant of CJD is also a rare and fatal neurodegenerative disease with symptoms similar to BSE in cattle. Regardless of their age, humans can contract vCJD by eating the beef of cattle that had mad cow disease. 
From 1998 to 2000, an inquiry was made into the BSE affair in the UK. It concluded that about 4.5 million cattle had been slaughtered since 1996, and that about 80 people had died of $\mathrm{VCJD}$. The report charged UK ministers and civil servants with having deliberately refused to consider the possibility of BSE spreading to humans in the early stages of the outbreak, trying instead to cover up the BSE fiasco to avoid disrupting the British beef export market. The European Commission was also strongly criticized, especially by the European Parliament (EP, "Parliament"), for having failed to act on the issue of BSE during the early 1990s. Among other points, it was charged with having pursued a policy of disinformation between 1990 and 1994, and with having downplayed the problem for economic reasons.

It is in this climate of public fear of BSE and distrust of national and EU institutions $^{53}$ that first US shipments of GM corn and soybeans arrived in European ports starting in the fall of 1996. The EU had given the green light for the commercialization of Monsanto's GTS40/3/2 herbicide tolerant soybean in April, and of Novartis's (now Syngenta) Bt176 insect resistant corn in January 1997. Environmental activist organizations such as Greenpeace responded by blocking the entry of individual ships, for the first time attracting public attention

\footnotetext{
${ }^{53}$ During this period, two further scandals had a negative impact on citizens' trust in government and regulatory institutions, and illustrated the spreading institutional crisis in Europe. The first is the so-called "tainted blood scandal" that took place in France during this time. In the early 1980s, some 1,300 hemophiliacs, many of them children, were infected with Acquired Immune Deficiency Syndrome (AIDS) through blood transfusions that French government medical authorities knew could be contaminated with the Human Immunodeficiency Virus (HIV). Although informed of the risk of not testing blood for transfusions, the French government did not start requiring blood testing for HIV until mid-1985, at least partially in order to wait to be able to use a test of French make instead of an American-produced test. By 1997, over 500 people had died through HIV-contaminated blood. The scandal, which broke in 1991, led to several court cases. Several doctors were convicted, but Laurent Fabius, French Prime Minister in the 1980s, was exonerated in March 1999. Like BSE, this event had nothing to do with genetic engineering, but it appeared to the public as another illustration of how European political elites made unwise decisions and then avoided taking responsibility.

The second scandal was the May 1999 discovery of high levels of dioxin in chicken and egg products from Belgian farms. Dioxins are a group of chemicals that are formed by burning chlorine-based chemical compounds, and are highly persistent in the environment. Waste-burning incinerators are the main source of dioxin. Dioxins enter animal feed in a number of different ways, some of which are very difficult to avoid. Maximum levels of dioxin have been set and procedures put in place to monitor its presence. In the Belgian case, the source of the contamination was a fat-rendering company, which had incorporated dioxin and polychlorinated biphenyls (PCBs), another type of chemical, into fats used in animal feed. As a result, all potentially contaminated chicken and egg products in Belgium, as well as in other European countries, were destroyed.
} 
to the risks of genetic engineering and prompting the beginning of what would become profound public rejection of GM foods and crops.

On 27 January 1997, acting not as a response to nascent critical public opinion, but as a belated concession to industry's lobbying for GM food regulation that was less stringent than Council Directive 90/220 on environmental release, the European Parliament and Council approved Regulation 258/97 (European Parliament/Council of the European Union 1997). This so-called "Novel Foods Regulation" applied to foods and food ingredients containing, consisting of, or produced from genetically modified organisms. It was the first regulation to make labeling of GM foods mandatory, but did not introduce a threshold.

It also included the contested "substantial equivalence clause" applying to foods or food ingredients "substantially equivalent to existing foods or food ingredients as regards their composition, nutritional value, metabolism, intended use and the level of undesirable substance contained therein" (see EP/Council Reg. 258/97, articles [art.] 3 and 5). Substantially equivalent foods underwent a simplified procedure, consisting essentially of the applicant's notification directly to the European Commission ${ }^{54}$ in order to ensure efficient regulation of processed foods containing GMOs.

On 22 February 1997, the world was shaken by another news item from the UK: the birth, having taken place in July 1996, of a cloned sheep named Dolly. Created by the Roslin Institute in Edinburgh, Dolly was the world's first clone of an adult mammal. While her birth was seen by scientists as a major breakthrough, large parts of the public, in Europe and elsewhere, felt that cloning, a type of genetic engineering allowing the duplication of existing organisms or genetic material, raised new and serious ethical questions.

Around the time that the news of Dolly aired, some EU Member States were beginning to respond to growing public uncertainty and rejection of GM foods, and to call for a fundamental toughening of existing EU-level rules. A particular point of critique was the substantial equivalence clause contained in the

${ }^{54}$ This is in contrast to an application made to a national competent authority, as was the case under Council Directive 90/220 and as remains the case under EP and Council Directive 2001/18 and EP and Council Regulation 1829/2003. Regulation 258/97 foresaw the possibility of objection through Member States, but it is less developed than in the case of Council Directive 90/220. 
Novel Foods Regulation, which seemed to some Member States to allow GM foods in "through the back door" without rigorous review. ${ }^{55}$ Other requests were for a generally more precautionary stance, and for more transparency and public involvement. EU Member States acted by beginning to use the "safeguard clause" $" 56$ contained in both Directive 90/220 and in the Novel Foods Regulation. In February and March 1997, Austria and Luxembourg both invoked the clause to ban Bt176 corn, the first Bt corn approved for commercialization in both the EU and the United States, from their national territories.

A further practical blow was dealt to GM foods and crops in May 1998, when the UK supermarket Iceland became the first European supermarket to go "GM-free" in response to consumer demands. In the years to follow, many major food retailers around Europe followed Iceland's example.

Then, in August 1998, GM potatoes hit the news. Hungarian-born scientist Árpád Pusztai, a researcher at the Rowett Research Institute, the UK's leading food safety research lab, announced the results of experiments in which he had fed GM potatoes to rats on British television. He had observed that the rats suffered serious damage to their immune systems and showed stunted growth. A few days after Pusztai's appearance, the Rowett Institute suspended him, the formal reason being that he had presented the results publicly before they had been peer-reviewed by other scientists as required by Rowett Research Institute procedures. The results of Pusztai's experiments were discredited by GM food supporters, and touted by GM critics. Within this climate of mixed signals, the UK public, as well as EU citizens in general, were increasingly unsure as to the safety of GM foods, the impartiality of scientific information, and the competence of European governments to make sound policy decisions.

\footnotetext{
${ }^{55}$ On this point, Levidow and Murphy (2002) give a useful account of what they call the "decline of substantial equivalence".

${ }^{56}$ The safeguard clause is based on article 95 of the Treaty establishing the European Community (consolidated text, 2002). It was included in Council Directive 90/220 (art. 16) and remains part of EP and Council Directive 2001/18 (art. 23), as well as EP and Council Regulation 258/97 (art. 12). It provides the possibility for Member States to take "national safeguard measures" by provisionally restricting or prohibiting the use and/or sale of individual GM products on their national territory if they have grounds to believe that those products may be harmful to health or the environment. Between January 1998 and August 2005, the safeguard clause has been invoked ten times, three times by Austria, twice by France, and once each by Germany, Greece, Hungary, Luxembourg, and the UK. Only the UK has withdrawn its ban.
} 
Pusztai later published the results of his study in The Lancet, but his experiments remain controversial to this day.

Despite these mounting signs of concern and criticism by the public and some Member States, between 1996 and 1998, the EU authorized a series of GM crops including oilseed rape, corn, and cotton under Council Directive 90/220 and the Novel Foods Regulation. However, individual Member States were increasingly discontent with the EU's regulatory regime on GMOs. 1998 and 1999 brought further national invocations of the safeguard clause by Greece, France, and Austria.

The discontentment was compounded by the resignation of the European Commission in 1999. Jacques Santer's Commission, in office since 1995, was accused of fraud, mismanagement, and withholding information. It entered a deep crisis in 1998, when the European Parliament refused to discharge the proposed budget (i.e. to formally request the Commission to implement the budget). As a result, the Santer Commission resigned en bloc on 15 March 1999, leaving the European Commission politically weakened.

This is the context within which the de facto Moratorium was pronounced. During the Council meeting of EU environmental ministers held on 24 and 25 June 1999, prompted by explicit calls from Greece and France, ("EU Ministers 'ban' GMOs, delay scrap car law” 1999), the delegations from Denmark, Greece, France, Italy and Luxembourg stated that, pending the adoption of rules on labeling and traceability of GMOs and GMO-derived products, they would "take steps to have any new authorizations for growing and placing on the market suspended" (Council of the European Union 1999b: annex III). They were later joined by Belgium and Austria. ${ }^{57}$ The June 1999 statement

${ }^{57}$ Together, the Member States listed were able to block GMO approvals within the Council of the EU. As will be explained in Chapter 4, particularly controversial authorization procedures can reach the level of the Council of the European Union. In this case, approvals must be made by "qualified majority". Under this voting system, Member States have a certain number of votes, depending roughly on their size and population. At the time of the de facto moratorium, Germany, France, Italy and the United Kingdom had 10 votes; Spain had 8; Belgium, Greece, the Netherlands, and Portugal had 5; Austria and Sweden had 4; Denmark, Ireland and Finland had 3; and Luxembourg had 2 votes (for a total of 87). A qualified majority required 62 votes (71.3\%), and 26 votes constituted a so-called blocking minority, that is, a number of votes sufficient to block approval.

Since 2004, when 10 new Member States joined the EU, the threshold for a qualified majority is 232 votes out of $321(72.2 \%)$, with a blocking threshold of 90 votes. In addition, the proposal must be backed by a majority of Member States and the countries supporting the proposal must 
marked the beginning of the EU's so-called de facto moratorium ${ }^{58}$ on GMOs. Before this date, the last approvals of GM plants had been the authorization of two GM carnations in October 1998, and of three varieties of GM corn and one type of GM oilseed rape in April 1998.

2000-2005: the EU moves toward stricter regulation The third phase describing GM food development and regulation in the EU began in 2000 and continues into the present. This phase is characterized by EU institutions' effort to toughen EU regulations on GMOs. Key events are the 2001 passage of EP and Council Directive 2001/18 (revised Directive 90/220, European Parliament/Council of the European Union 2001), the 2003 passage of EP and Council Regulations on labeling and traceability of GM food and feed (European Parliament/Council of the European Union 2003a, 2003b), as well as the first approval, in 2004, of a GMO since 1999 and therefore the lifting of the 1999 de facto moratorium.

This phase encountered one more public health crisis. Just as the shock of BSE was starting to fade, an epidemic of Foot and Mouth Disease (FMD) took hold of the UK in 2001. FMD is an infectious and highly contagious disease affecting cloven hoofed animals such as cattle, swine, goats and sheep. Between February and September 2001, over 2000 infected premises were registered in the $\mathrm{UK}$, and it is estimated that about 6 million animals were slaughtered in order to gain control of the situation. Aside from the economic impact of the epidemic on the UK's farming sector, the 2001 FMD epidemic once again raised questions in European citizens' minds about the capacity of governments to avoid and, if necessary, address public health crises.

Returning to the EU's GM food and crop regulation, one of the first measures taken by the European Commission in response to the de facto moratorium was to adopt new regulations on labeling which would serve as an interim solution until new measures could be taken. While previous rules had

represent at least $62 \%$ of the total EU population. Votes are distributed as follows: France, Germany, Italy and the United Kingdom: 29 votes; Poland and Spain: 27 votes; Netherlands: 13 votes; Belgium, Czech Republic, Greece, Hungary and Portugal: 12 votes; Austria and Sweden: 10 votes; Denmark, Finland, Ireland, Lithuania and Slovakia: 7 votes; Cyprus, Estonia, Latvia, Luxembourg and Slovenia: 4 votes; Malta: 3 votes.

${ }^{58}$ This moratorium was "de facto" because it had no legal basis within EU law. For this reason, GM foods proponents called it illegal. 
only specified that foods containing GMOs should be labeled, Regulation 49/2000 (European Commission 2000a) settled the much-debated threshold issue, making labeling mandatory above a $1 \%$ adventitious (i.e. accidental) GM-content of individual food ingredients. It also extended requirements to foods delivered to final consumers and food caterers. Regulation 50/2000 addressed the labeling of GM food additives and flavorings (European Commission 2000b).

The next task was to complete the review of Directive 90/220, which had been launched by the European Commission in 1998, and to address the issues of labeling and traceability not only for foods, but also for feed. In March 2001, Directive 2001/18 was passed (European Parliament/Council of the European Union 2001). This Directive, to be transposed by EU Member States by 17 October 2002, was a considerably revised and more restrictive version of Directive 90/220. It explicitly named the precautionary principle and did not include a substantial equivalence clause like the Novel Foods Regulation. It also placed an increased emphasis on public and stakeholder consultation and participation in the decision-making process. Member States generally welcomed these developments, but insisted on new labeling and traceability regulations before lifting the de facto moratorium.

Such regulations were finally adopted on 22 Sept. 2003, and came into force on 18 April 2004. EP and Council Regulations 1829/2003 on GM food and feed (European Parliament/Council of the European Union 2003a), and 1830/2003 (European Parliament/Council of the European Union 2003b) on the traceability and labeling of GM food and feed set up a stricter authorization procedure which repealed the Novel Foods Regulation, toughened labeling rules, and for the first time addressed the issues of traceability and feed. A further important innovation was the creation of a new independent food agency, the European Food Safety Authority (EFSA). As detailed under the US chronology, these new regulations came too late to avert the US-led WTO complaint against the European Union in May 2003.

Armed with new regulations on GM food and feed, the EU was ready to for a "de facto lifting" of its de facto moratorium. On 19 May 2004, this step was taken through the Commission's approval of Syngenta's Bt1 1 corn. The approval of Monsanto's NK603 corn followed in October 2003. These recent 
authorizations, however, do not mean that controversy on GM foods has subsided. Each new authorization is contentious. Since 2004, each time the European Commission has asked EU Member States to vote on authorizing a GMO food or feed product, agreement has not been possible. When Member State representatives within the Council of Ministers cannot agree ${ }^{59}$, EU comitology rules $^{60}$ foresee that the Commission adopt the decision in question, which is why new approvals have been possible. In June 2005, a majority of EU environment ministers reaffirmed their voice in the GMO debate by voting to allow individual Member States to keep their national bans in place. As explained in Chapter 1, contentious issues on the current EU agenda are coexistence, liability, and the labeling threshold for GM seed.

\footnotetext{
${ }^{59}$ Relatively constant opponents of GM food and crops over the past years have been Austria, Denmark, Greece and Luxembourg. Relatively steady supporters have included Finland, Sweden, the Netherlands and the United Kingdom. Changes in national governments have influenced voting patterns, for example in the case of Spain, which was a steady supporter of GM crops and foods until a new socialist government took office in the spring of 2004. It now routinely abstains from voting. The voting records of the Member States that joined the EU in 2004 are too brief to reveal clear patterns yet.

${ }^{60}$ Comitology refers to the rules foreseen when the Commission is assisted by a committee (advisory, management or regulatory) made up of Member State representatives. Council Decision 1999/468 lays down "comitology" rules and procedures. Both Dir. 2001/18 and Reg. 1829/2003 make reference to this decision. Council Dir. 90/220 and EP and Council Reg. 258/97 foresaw a similar procedure.
} 


\section{GM Food Policy: A Transatlantic CoMParison}

What is my focus when I ask why and how GM food policies are different? What, in short, is my dependent variable? In this chapter, I describe and analyze US and EU genetically modified food policies, and clarify the statement used previously that US policy regarding GM food is relatively permissive, while the EU's policy is relatively restrictive. ${ }^{61}$ This dissertation uses the term "permissive" as a synonym of permitting or lenient, meaning a tendency to enable actions and grant liberties. "Restrictive" is used in the sense of stringent or limiting, and implies a boundary beyond which something or someone cannot or is not permitted to go. A policy is more restrictive (permissive) than another policy if it limits the actions of its target groups ${ }^{62}$ to a greater (lesser) extent. Levels of restrictiveness or permissiveness of a GM food policy can be determined by assessing the formal rules and restrictions it contains, as well as by observing its impact on the actors affected by them.

Accordingly, in this chapter, I compare the levels of restrictiveness and permissiveness of GM food policies both in terms of what rules and regulations foresee, and in terms of the practical outcome of these policies. I first contrast US and EU regulatory frameworks for GM food and crops, focusing on explicit principles, on the institutions dealing with this policy area, and on relevant rules (laws, regulations, other policy documents). I then compare US and EU authorization procedures for field tests (or field trials) and commercialization (3.2 and 3.3). Regarding formal rules, I am especially attentive to:

- numbers of regulatory steps foreseen (e.g. receipt of application, consultation, formal authorization etc.),

- maximum time foreseen until authorization,

- length of validity of authorization,

- monitoring and reporting provisions,

- other restrictions and limitations.

${ }^{61}$ This policy difference is also the focus of Bernauer 2003, Isaac 2002, and Meins 2003.

${ }^{62}$ Target groups are the actors whose behavior a policy attempts to influence in order to reach certain policy objectives. 
Regarding the practical results of GM food policies, I highlight: ${ }^{63}$

- numbers of applications,

- numbers of authorizations,

- numbers of non-authorized GM foods and crops,

- average number of days elapsed between application and authorization.

\subsection{Regulatory frameworks}

\section{Explicit guiding principles: product versus process}

In the US, regulatory emphasis is on the end product. GM food policy is based on the premise that GMOs and foods derived from GMOs should be regulated like any other food, irrespective of their method of production. This is often referred to as a "product-based approach". In contrast, EU policy takes a "process-oriented approach", which posits that the process of production is what should trigger a specific regulatory process. It follows that GM foods and crops should be regulated as such because they are produced through genetic engineering, a specific production process. ${ }^{64}$

${ }^{63}$ The data used in this chapter is up to date as of mid-2005. The graphs cover time periods as specified in each individual case. In order to make EU and US data comparable, for US-EU comparisons, the period covered is late 1991 to mid-2005: in the EU, first authorizations were made in October 1991, whereas the US began approving field tests in 1987. Sources used to compile data are the following:

- Animal and Plant Health Inspection Service Biotechnology Permits Database

- Environmental Protection Agency Plant Incorporated Protectants

- European Commission Biotechnology (Environment Directorate-General)

- European Commission Deliberate releases and placing on the EU market of Genetically Modified Organisms (GMOs) (Joint Research Centre Directorate-General)

- European Commission Genetically Modified (GM) Foods authorised in the European Union under the Novel Foods Regulation (EC) 258/97 (Health and Consumer Protection DirectorateGeneral)

- European Commission GM Food \& Feed-Authorisation

- European Food Safety Authority Applications under Regulation (EC) 1829/2003 on Genetically Modified Food and Feed [GM Food Feed applications]

- Food and Drug Administration List of Completed Consultations on Bioengineered Foods

- Organisation for Economic Co-operation and Development BioTrack Product Database

- Virginia Tech Information Systems for Biotechnology Field Test Releases in the U.S. (searchable database of APHIS data)

${ }^{64}$ The distinction between "product" and "process" is central to understanding the differences between US and EU regulation in the area of agricultural biotechnology. As this chapter will 
The "product versus process" distinction is connected with dissimilar perceptions of modern biotechnology. US documents convey the notion that genetic engineering is nothing radically new, but merely a natural extension of traditional agricultural breeding (Office of Science and Technology Policy 1984: 50856). US policy documents frequently call attention to the fact that plant biotechnology has been used for a long time in less sophisticated ways than are possible with rDNA technology:

"the recently developed methods [i.e. rDNA techniques] are an extension of traditional manipulations that can produce similar or identical products [and] enable more precise genetic modifications" (Office of Science and Technology Policy 1986: 23302).

EPA's online Introduction to Biotechnology Regulation for Pesticides instructs the reader that "[f]or centuries, humans have improved crop plants through selective breeding and hybridization [...] (Environmental Protection Agency. Introduction to Biotechnology Regulation for Pesticides). Similarly, FDA points out that "[m]ost, if not all, cultivated food crops have been genetically modified" (Food and Drug Administration 1992: 22984, footnote 3). Accordingly, FDA defines "genetic modification" as "the alteration of the genotype of a plant using any technique, new or traditional" (ibid.). ${ }^{65}$

The EU, on the other hand, views genetic engineering as a stark departure from conventional technologies. Its definition of GMO illustrates this point:

GMO "means an organism [...] in which the genetic material has been altered in a way that does not occur naturally by mating and/or natural

show, however, in some cases the practical application of the product-based approach is ambiguous. While APHIS and EPA claim to regulate the products of biotechnology irrespective of their process of production, they have in practice created new definitions, categories, and even regulations to address GM foods and crops. Noting the discrepancy between the theory and practice of product-based regulation, the Pew Initiative on Food and Biotechnology writes that "the bright line between process and product has become substantially more difficult to draw, and thus the distinction has become less useful." The Pew Initiative suggests that this evolution has resulted from "the difficulty of fitting biotechnology products into pre-existing legal categories" (Pew Initiative on Food and Biotechnology 2004a: 24).

${ }^{65}$ Of the US agencies that regulate agricultural biotechnology, FDA has been the most vocal supporter and most straightforward implementer of the product-based principle. This staunch support might be connected to the fact that by the time a product is ready for FDA oversight, the process of production has already been reviewed. As put by an FDA official interviewed by Jones: "we were able to say product not process because we captured process anyway" (Jones 1999: 261). 
recombination" (EP and Council Dir. 2001/18, art. 2.1, European Parliament/Council of the European Union 2001).

This definition contains the notion that genetic engineering is something fundamentally new and different. This is why, "unlike any other genetic improvement methods, the application of this technology is strictly regulated" (European Commission 2005a: 3).

The consequence of these different assessments of GM food technology is that the United States does not have a regulatory regime specific to agricultural biotechnology or biotechnology in general, whereas the European Union does. When the US government began developing biotechnology regulation in the early 1980s, it operated on the principle that existing laws and regulations were adequate to deal with the new policy area. The 1986 Coordinated Framework, the US's central policy document on the regulation of biotechnology, explains that at that time,

"[...] there did not appear to be an alternative, unitary, statutory approach since the very broad spectrum of products obtained with genetic engineering cut across many product uses regulated by different agencies" (Office of Science and Technology Policy 1986: 23302).

This decision implicitly also meant that the establishment of fewer rules regarding the development and commercialization of GM foods and crops than would have been the case for a class of products regulated under a new law. In contrast, the European Union began in the late 1980s to develop a framework specifically designed to regulate GMOs and GM foods. This framework, revised and expanded throughout the 1990s, persists into the present decade.

\section{Responsible institutions, regulatory frameworks}

US executive branch institutions dealing with GM crop and food policy are the Office of Science and Technology Policy, answering directly to the President of the United States, ${ }^{66}$ the Food and Drug Administration (FDA) (part of the United States Department of Health and Human Services, HHS), the

${ }^{66}$ The Office of Science and Technology Policy (OSTP) is part of the US executive branch. It was established in 1976 with a broad mandate to advise the President and White House on matters pertaining to science and technology. 
Environmental Protection Agency (EPA, independent), the Animal and Plant Health Inspection Service (APHIS) (part of the United States Department of Agriculture's, USDA). The US's federal legislative branch is the United States Congress. The United States is made up of 50 US states, which in turn each have state governments and legislatures.

The Constitution of the United States, originating in 1789, and the United States Code (US Code, USC), the codification by subject matter of US laws, together constitute the main legal basis for the regulation of GM food and crops. The Code of Federal Regulations (CFR) is next in terms of legal hierarchy, and is the codification of rules published by the executive departments and agencies of the federal government. In the absence of rules codified as part of the CFR, policy documents such as "announcements of policy" and "statements of policy" represent a legal basis for regulation.

The United States Constitution gives the US Congress the "power to [...] provide for the [...] general welfare of the United States" and to "regulate Commerce with foreign Nations, and among the several States [...] (Constitution of the United States of America, art. I Section 8). These broad powers, in particular the power to regulate commerce, ${ }^{67}$ are what legitimate the US Congress to legislate and the executive branch to regulate in the areas of food and agriculture, the two areas under which agricultural biotechnology is addressed.

Working within this broad mandate, by the end of 1984, the US Office of Science and Technology Policy had devised a "regulatory matrix" of existing federal agencies and laws to regulate biotechnology, which was confirmed by the Coordinated Framework in 1986 (Office of Science and Technology Policy 1984, 1986) and reiterated in 1992 (Office of Science and Technology Policy 1992). ${ }^{68}$ The legal basis for GM food and crop regulation in the US consists of three statutes, which are implemented by three federal agencies.

\footnotetext{
${ }^{67}$ The so-called "Commerce Clause" (Constitution of the United States of America, art. I, section 8.3) "has been cited as the constitutional basis for a significant portion of the laws passed by the Congress over the last fifty years, and it currently represents one of the broadest bases for the exercise of congressional powers" (Thomas 2001: 2). Indeed, the statutes applied to biotechnology, categorized under "agriculture" and "food and drugs" make reference to international and inter-state commerce involving food, plants and pesticides.

${ }^{68}$ Anderson et al. 2001 offer a detailed description of US biotechnology policy from a legal perspective.
} 
First, the Animal and Plant Health Inspection Service is responsible for protecting US agriculture from pests and diseases under the Plant Protection Act (PPA) of 2000 (United States Code, Title 7, §301 et seq.). ${ }^{69}$ It is classified under the Agriculture Title of the United States Code (codification by subject matter of US laws).

Second, the Food and Drug Administration ensures that food, feed, and food additives are properly labeled and safe to eat for humans and animals under the Federal Food, Drug, and Cosmetic Act (FFDCA) of 1938 (United States Code, Title 21, $\$ 301$ et seq.). The FFDCA is part if the US Code’s Title dealing with Foods and Drugs.

Third, the Environmental Protection Agency ensures that pesticides used in plants are safe for the environment under the Federal Insecticide, Fungicide, and Rodenticide Act (FIFRA) of 1947 (United States Code, Title 7, § 136 et seq.). EPA also defines pesticide residue tolerances in food under FFDCA ("safe for the environment/safe to eat"). The statutes applied by EPA are found both under the Agriculture and Food/Drugs Titles of the US Code.

In order to regulate GM foods and crops, FDA, APHIS and EPA have implemented and interpreted the PPA, FIFRA, and FFDCA through various secondary legal tools, which all deal with specific areas of plant biotechnology. FDA's 1992 "Statement of Policy: Foods Derived From New Plant Varieties" (Food and Drug Administration 1992) is the Agency's central policy document on GM food. In the absence of a law or regulation, it outlines the FDA's policy. This document establishes the principle of treating GM foods like non-GM foods. It does not request pre-market review of a GM food except if the food could be hazardous for a reason unconnected with the fact that it was produced through genetic engineering. APHIS in practice mandates systematic oversight of most GM crops under the Code of Federal Regulations (Title 7, Part 340), by defining them as potential plant pests. Finally, EPA fulfills its mandate by regulating the insecticidal substances produced by Bt plants as pesticides or "plant-incorporated protectants" (PIPs).

${ }^{69}$ Rules on GM crops were developed under the PPA's predecessor Federal Plant Pest Act (FPPA) of 1957. They will remain in force until new regulations are developed. So far, APHIS has not issued any new regulations. 
Main institutions dealing with GM food and crops at the EU level regulation are the European Commission ("Commission"), the European Parliament ("Parliament", EP), the Council of the European Union ("Council of the EU", "Council"), and the European Food Safety Agency (EFSA). The EU Member States' national authorities are responsible for implementing and enforcing the EU's GM food and crop policy. The European Commission is instrumental in proposing legislation, which is then debated and passed by the European Parliament. Commission Directorate Generals dealing with the environment and with health and consumer protection have been particularly important in proposing legislation on GM foods and crops. They have worked together with the Directorate-Generals responsible for enterprise and industry, and for research and technology development (RTD). EU Member States, represented in the Council of the EU and in regulatory committees, ultimately have the power to adopt or reject proposed regulations. A relatively new actor within the EU's food policy arena is the European Food Safety Agency (EFSA), created in 2002. It now plays an important role in the authorization of GM foods and crops.

In the EU, the primary legal text for regulating GM foods and crops is the Treaty establishing the European Community ${ }^{70}$. Next come directives and regulations, which are types of "secondary legislation" in European Community law. Secondary legislation consists of "directives" (binding for Member States as to objectives to be achieved; implementation to be carried out by Member State national authorities), "regulations" (directly applicable and binding in all EU Member States), “decisions" (binding for addressees), "recommendations”, and “opinions" (not binding) (European Union. Key players in EU legislation - EU law-definitions).

Article 95 of the Treaty establishing the European Community (consolidated text, 2002) includes the goal of harmonizing national laws in order to establish an internal market. ${ }^{71}$ Article 95.3 underlines that legislation pursuing

\footnotetext{
${ }^{70}$ The "Treaty establishing the European Community" deals with all policies in the European Union's first or "community pillar", which includes environmental policy. A separate "Treaty on European Union" addresses the two other pillars of the European Union: "Common Foreign and Security Policy" (second pillar) and "Police and Judicial Co-operation in Criminal matters" (PJCC) (formerly "Justice and Home Affairs", JHA).

${ }^{71}$ The goal of a European "internal market" dates back to the 1957 Treaty of Rome (Treaty establishing the European Economic Community 1957), which set the goal of the creation of a
} 
this goal and pertaining to environmental and consumer protection "will take as a base a high level of protection". Articles 95.4 to 95.10 provide the legal basis for the safeguard clauses included in the EU's GMO policy that allow Member States to suspend individual GM products from their territory if they regard this as necessary to protect the environment.

EU secondary legislation and regulation on GMOs can be divided into "horizontal" legislation, which deals with the environmental release of GMOs in a broad sense, and "vertical" or "sector-related" legislation or regulation, which covers specific products made with GMOs (e.g. food, feed, seed, medicine) and individual issues related to them (labeling, traceability). Accordingly, EU rules relevant to GM foods and crops cover two main types of authorization: deliberate release of GMOs into the environment and use in GM food and feed. EP and Council Directive 2001/18/EC of 2001 (European Parliament/Council of the European Union 2001) is the horizontal piece of legislation covering the deliberate release into the environment of genetically modified organisms, both for experimental purposes and for placing on the market. It came into force in October 2002, replacing its predecessor, Council Directive 90/220/EEC (Council of the European Union 1990). Main "vertical” instruments within the EU are EP and Council Regulation 1829/2003 (European Parliament/Council of the European Union 2003a) on genetically modified food and feed which replaced EP and Council Regulation 258/97 on Novel Foods (European Parliament / Council of the European Union 1997) ${ }^{72}$ in 2004, and EP and Council Regulation $1830 / 2003$ on traceability and labeling ${ }^{73}$ (European Parliament/Council of the European Union 2003b). Tables 4 and 5 summarize US and EU regulatory frameworks on GM foods and crops.

"common market" based on the free movement of goods, persons, services and capital. In 1986, the Single European Act gave this goal new impetus by inserting into the Treaty establishing the European Community an article on measures to complete the internal market (art. 100a, now art. 95). The internal market was declared complete by 1992.

${ }^{72} \mathrm{EP}$ and Council Regulation 258/97 is still in force since a few applications for authorization are still pending under its provisions. Important innovations of the new Regulation on GM Food and Feed include the introduction of the European Food Safety Agency as part of the decision-making process, and the removal of the simplified authorization procedure on the basis of a "substantial equivalence" finding, i.e. an observation that the product characteristics of a GM food do not depart significantly from its traditional counterpart.

${ }^{73} \mathrm{GM}$ food labeling rules were previously covered by EP and Council regulation 258/97, Council Regulation 1139/98 (Council of the European Union 1998), Commission Regulation 49/2000 (European Commission 2000a) and Commission Regulation 50/2000 (European Commission 2000b). 


\section{Table 4: US regulatory framework for GM crops and foods}

US Constitution and Federal Statutes
Constitution of the United States of Amercica
Plant Protection Act (PPA), US Code, Title 7 (Agriculture), Chapter 104, §7701 et seq.
Federal Food, Drug, and Cosmetic Act (FFDCA), US Code, Title 21 (Food and Drugs),
Chapter 9, §301 et seq.
Federal Insecticide, Fungicide, and Rodenticide Act (FIFRA), US Code, Title 7
(Agriculture), Chapter 6, §136 et seq.
Office of Science and Technology Policy (OSTP)
1986: Coordinated Framework for Regulation of Biotechnology (Announcement of Policy
and Notice for Public Comment)
1992: Exercise of Federal Oversight within Scope of Statutory Authority: Planned
Introductions of Biotechnology Products into the Environment (Announcement of Policy)
Food and Drug Administration (FDA)
1992: Statement of Policy: Foods Derived From New Plant Varieties (Notice)
1997: Guidance on Consultation Procedures: Foods Derived from New Plant Varieties
Environmental Protection Agency (EPA)
Code of Federal Regulations, Title 40 (Protection of the Environment), Part 152 (Pesticide
Registration and Classification Procedures) (40 CFR 152)
Code of Federal Regulations, Title 40 (Protection of the Environment), Part 174 (Procedures
and Requirements for Plant-Incorporated Protectants) (40 CFR 174)
Animal and Plant Health Inspection Service (APHIS)
Code of Federal Regulations, Title 7 (Agriculture), Part 340 (Introduction Of Organisms And
Products Altered Or Produced Through Genetic Engineering Which Are Plant Pests Or
Which There Is Reason To Believe Are Plant Pests) (7 CFR 340)

Table 5: EU regulatory framework for GM crops and foods

Treaty and horizontal legislation
Treaty establishing the European Community (consolidated text)
2001: Directive $2001 / 18 / \mathrm{EC}$ of the European Parliament and of the Council of 12 March
2001 on the deliberate release into the environment of genetically modified organisms and
repealing Council Directive $90 / 220 / E E C$
Regulations
1997: Regulation (EC) No $258 / 97$ of the European Parliament and of the Council of 27
January 1997 concerning novel foods and novel food ingredients (repealed by $1829 / 2003$
in but still in use during transitional phase)
2003: Regulation (EC) No $1829 / 2003$ of the European Parliament and of the Council of 22
September 2003 on genetically modified food and feed
2003: Regulation (EC) No $1830 / 2003$ of the European Parliament and of the Council of 22
September 2003 concerning the traceability and labelling of genetically modified
organisms and the traceability of food and feed products produced from genetically
modified organisms

\subsection{Regulating field tests}

In the US, the field testing of GM plants is subject to USDA (APHIS) oversight. When a field trial involves the planting of GM crops containing a $\mathrm{Bt}$ toxin on more than ten acres, an additional application to EPA for an 
Experimental Use Permit (EUP) under the Code of Federal Regulations (Code of Federal Regulations, Title 40, Part 172, abbreviated 40 CFR 172) is necessary. The European Union regulates field testing under Directive 2001/18's Part B entitled "Deliberate Release of GMOs for any other purpose than for placing on the market" (European Parliament/Council of the European Union 2001).

\section{APHIS: permits and notifications}

Under the Plant Protection Act (PPA) (United States Code, Chapter 7, $\S 7701$ et seq., abbreviated 7 USC 7701 et seq.), USDA has the responsibility to protect agriculture from plant pests (7 USC 701(3)) and to oversee pesticide authorizations (7 USC 7711). Part 340 of the Code of Federal Regulations (Code of Federal Regulations, Title 7, Part 340, abbreviated 7 CFR 340), applying specifically to genetically engineered organisms, defines GM crops as "regulated articles", which are "any organism which has been altered or produced through genetic engineering, [...] and meets the definition of plant pest [...]" (7 CFR 340.1). This definition includes plant pests used during the modification process, even if they are not in the final product. During most such production processes, substances are used that qualify as plant pests under 7 CFR 340. In practice, therefore, most GM foods and crops field tested are subject to USDA (APHIS) oversight.

APHIS issues "permits" under 7 CFR 340.4 or acknowledges "notifications" under 7 CFR 340.3. Permits and notifications can be for release into the environment (field tests), import from abroad, and/or interstate movement. Getting a permit, a procedure introduced in 1987, is the more demanding of the two possible procedures. A notification is a streamlined version of the permit-granting procedure, and was introduced in 1993 for plant pests with a low risk potential. It was extended to most GM crops in 1997, and is now the most common way for applicants to obtain field test approval. Notification does not foresee a formal review. To fall under the notification procedure, plant pests must fulfill a series of criteria and performance standards (7 CFR 340.3.b and 7 CFR 340.3.c). Figures 7 and 8 give an overview of the more than 10,000 field tests authorized by APHIS (both permits and notifications) by type of crop and by trait. 
Figure 7: APHIS field test approvals by crop, 1987-2005

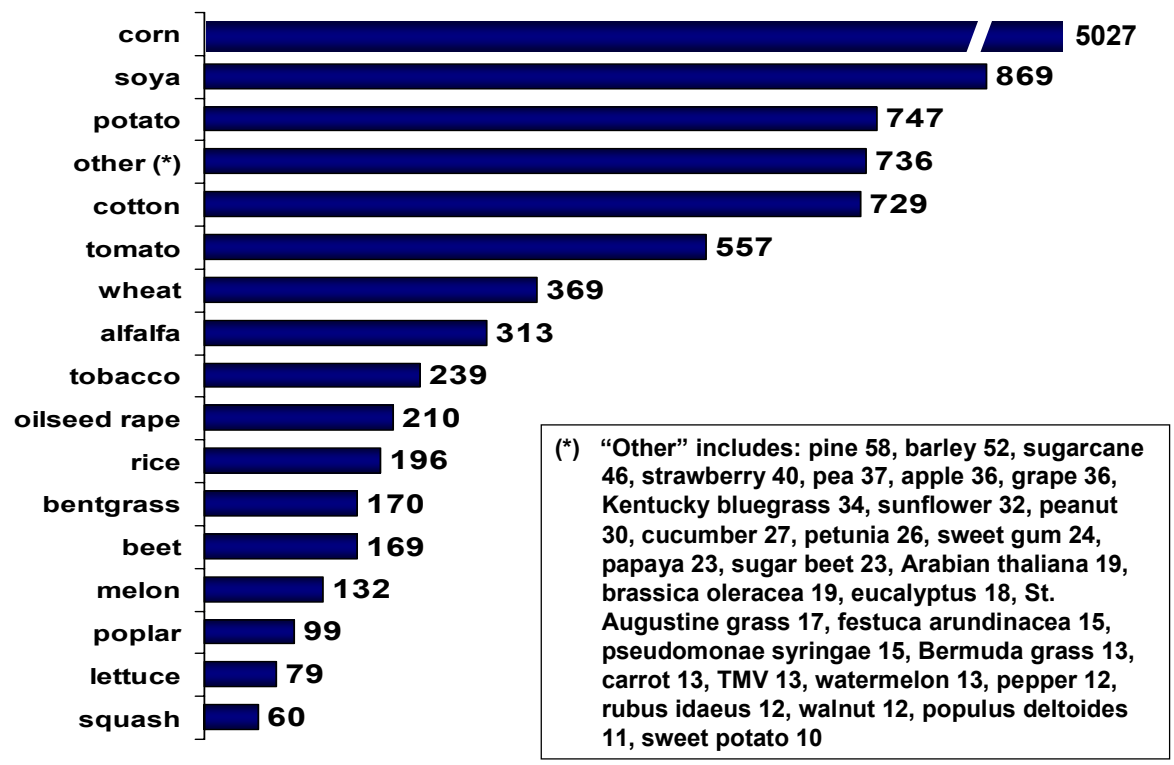

Source: Animal and Plant Health Inspection Service (APHIS) - Biotechnology Permits Database (May 2005)

Figure 8: APHIS field test approvals by trait, 1987-2005

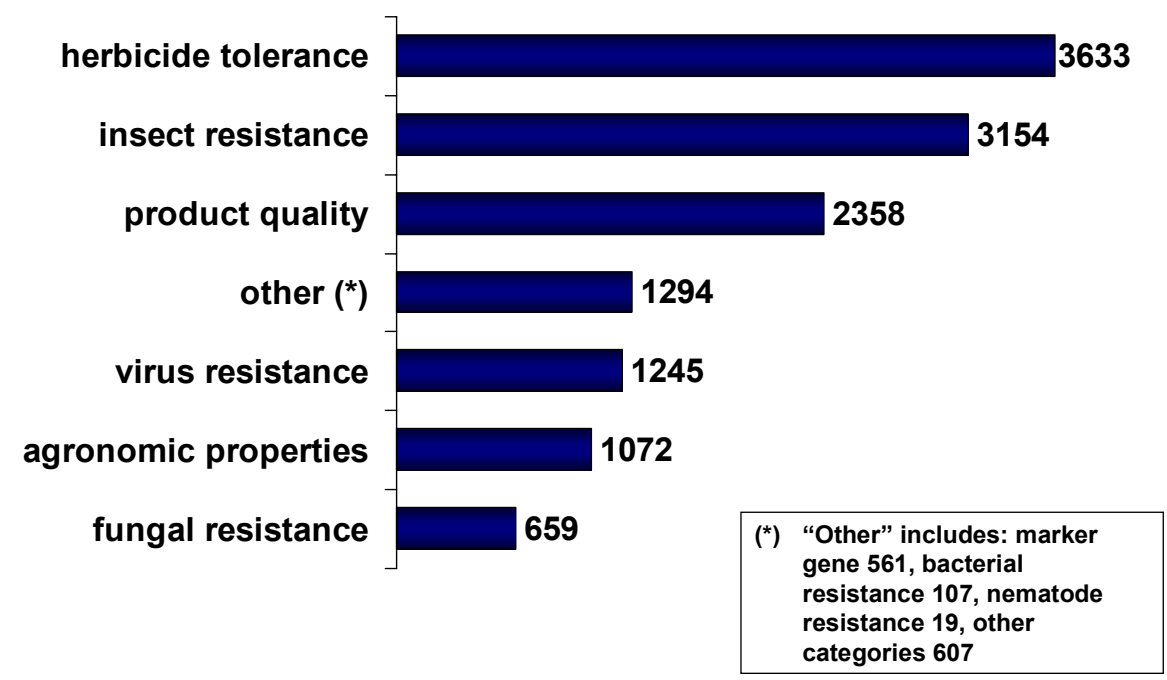

Source: Animal and Plant Health Inspection Service (APHIS) - Biotechnology Permits Database (May 2005)

\section{EU: Part B notification}

The European Union regulates GM plant field testing under Directive 2001/18's Part B regarding the “deliberate release of GMOs for any other 
purpose than for placing on the market" (European Parliament/Council of the European Union 2001). Under the "standard authorisation procedure" (art. 6), applicants ("notifiers") wishing to perform a deliberate release submit a notification to the "competent authority" (usually a ministry) of the Member State where the release is planned. The competent authority forwards a summary of this notification to the Commission, which in turn forwards it to the other Member States for comments. The competent authority takes into account these observations where appropriate before responding to the notifier. When sufficient experience exists regarding the release of specific GMOs in specific ecosystems, a competent authority can request a "differentiated procedure" making it possible to submit a single dossier for more than one GMO release (art. 7). Directive 2001/18 is noteworthy for its safeguard clause (art. 23), described above, which applies both to experimental releases (Part B) and to placing on the market (Part C, described below). Figure 9 gives an overview of Part B authorizations of GM plant field tests by type of crop.

Figure 9: EU field test approvals by type of crop, 1991-2005

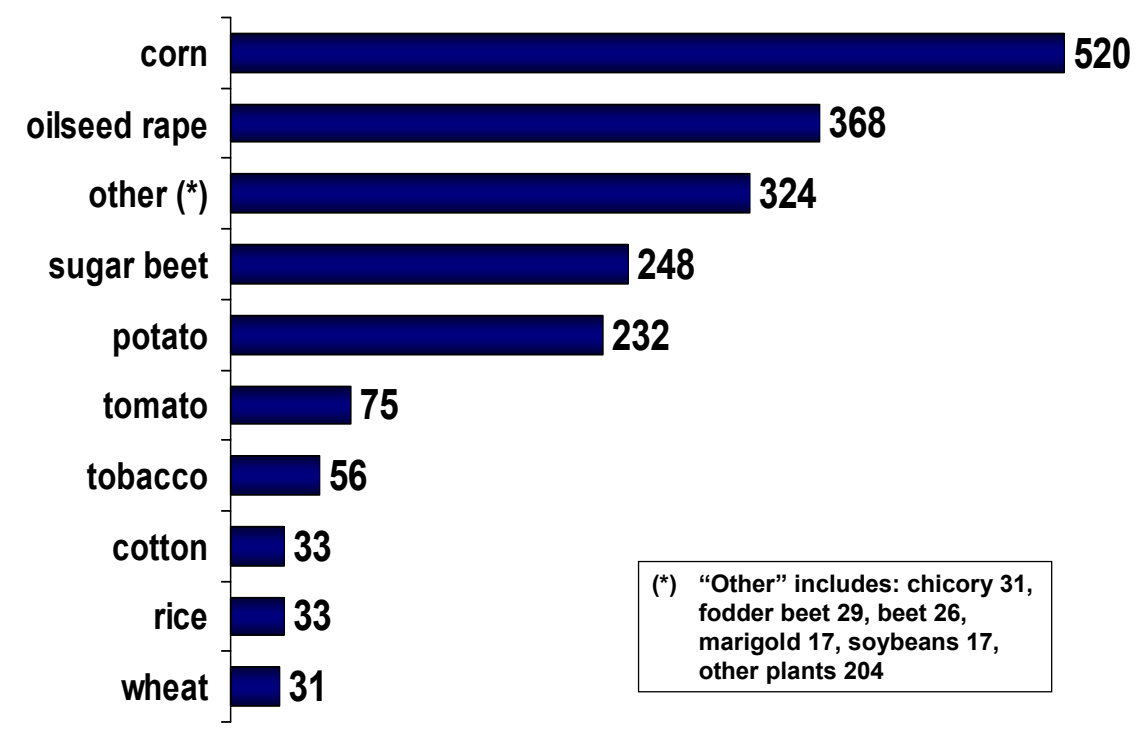

Source: European Commission - Deliberate releases and placing on the EU market of Genetically Modified Organisms (GMOs) (May 2005) 


\section{Comparing US and EU field trial regulations and their outputs}

A comparative look at US and EU regulations of field tests involving GM foods reveals a somewhat more restrictive set of EU regulations as compared to US rules (Table 6). ${ }^{74}$ This is almost consistently the case in comparison with the simpler "notification" provisions, whereas the "permit" and Part B are comparable.

Numbers of regulatory steps are equal cases or smaller in the US, depending on the US procedure in question. In the US, authorization takes four steps for permits (notification, initial review, full review, authorization), but only three for the more widely used notification procedure (notification, routine review, acknowledgment). In the EU, standard authorizations are completed in four steps (notification, review by competent authority, Member State and Commission comment period, answer).

In terms of time planned for authorization, the US foresees more time than the EU for permits, but significantly less for notifications. US notifications can take a maximum of only 30 days, while permits can take up to 120 days plus any time needed to receive missing information from the applicant and to conduct environmental impact assessments. EU Part B procedures foresee 90 days, plus extra time for information collection.

APHIS permits and notifications are valid for one year, but the former are not renewable, whereas the latter are. The EU grants field trial authorizations for periods that vary from a few months to several years, depending on the application. Renewal applications may be submitted.

Both the US and the EU foresee reporting after the end of field tests. In addition, APHIS can monitor test fields with permits, and Directive 2001/18 foresees public consultation and a public register of GMOs and GMO test sites.

\footnotetext{
74 The comparison is made between APHIS permit and notification rules and EU Directive 2001/18's Part B procedure as these are the two main procedures for field trial approvals in the US and the EU.
} 
Table 6: US and EU field test regulations for GM plants (as of 1 Aug. 2005)

\begin{tabular}{|c|c|c|c|}
\hline & \multicolumn{2}{|c|}{ US regulation of field trials } & \multirow{2}{*}{$\begin{array}{c}\text { EU regulation of field trials } \\
\text { EP/Council Directive 2001/18 Part B }\end{array}$} \\
\hline & $\begin{array}{c}\text { APHIS field test } \\
\text { permits }\end{array}$ & $\begin{array}{l}\text { APHIS field test } \\
\text { notifications }\end{array}$ & \\
\hline $\begin{array}{l}\text { Regulatory steps } \\
\text { foreseen }\end{array}$ & $\begin{array}{l}\text { 4 steps: } \\
\text { 1. notification } \\
\text { 2. initial review } \\
\text { 3. full review } \\
\text { 4. authorization }\end{array}$ & $\begin{array}{l}\text { 3 steps: } \\
\text { 1. notification } \\
\text { 2. routine review } \\
\text { 3. acknowledgment }\end{array}$ & $\begin{array}{l}\text { 4 steps: } \\
\text { 1. notification } \\
\text { 2. review by competent authority } \\
\text { 3. Member State and Commission } \\
\text { comment period } \\
\text { 4. answer }\end{array}$ \\
\hline $\begin{array}{l}\text { Time foreseen for } \\
\text { authorization }\end{array}$ & $\begin{array}{l}120 \text { days } \\
\text { (+ extra for } \\
\text { information } \\
\text { gathering) }\end{array}$ & 30 days & $\begin{array}{l}90 \\
\text { (+ extra for information gathering) }\end{array}$ \\
\hline $\begin{array}{l}\text { Expiration of } \\
\text { authorization }\end{array}$ & $\begin{array}{l}1 \text { year } \\
\text { non-renewable }\end{array}$ & $\begin{array}{l}1 \text { year } \\
\text { renewable }\end{array}$ & $\begin{array}{l}\text { several months to several years } \\
\text { renewal possible }\end{array}$ \\
\hline $\begin{array}{l}\text { Reporting, monitoring, } \\
\text { other restrictions }\end{array}$ & $\begin{array}{l}\text { - report within } 6 \\
\text { months of end } \\
\text { - APHIS may } \\
\text { always inspect }\end{array}$ & $\begin{array}{l}\text { report within } 6 \\
\text { months of end }\end{array}$ & $\begin{array}{l}\text { - regular reporting to European } \\
\text { Commission and Parliament } \\
\text { - public consultation } \\
\text { - public register of GMOs and GMO test } \\
\text { sites }\end{array}$ \\
\hline
\end{tabular}

What are the outputs of these regulations? As summarized in Table 7, the US boasts many more applications and authorizations than the EU, but rates of rejection and withdrawal are comparable. From 1991 to 2005, APHIS received 11,422 field trial applications (1,022 for permits and 10,400 for notifications), of which it authorized 10,706 (865 permits and 9,841 notifications). About one half of these authorizations were for corn varieties. 716 or roughly $6 \%$ of these were not authorized (refused or withdrawn). ${ }^{75}$ The non-authorization rate is about $15 \%$ for permits and $6 \%$ for notifications. During the same period, the EU processed 1,982 Part B notifications of field trials under directives 90/220 and 2001/18. Corn, oilseed rape, potatoes and sugar beets are the most widespread field trials in the EU. From the data available, it appears that approval rates are relatively high, with only about $3 \%$ of rejections and withdrawals. ${ }^{76}$ In terms of time elapsed between the time of application and authorization, the US is significantly faster with a weighted average of about 34 days (75 for permits, 30 for

${ }^{75}$ These figures do not include pending applications.

${ }^{76}$ The results of only 789 out of 1,982 Part B notifications are publicly available. Of these, 767 field trials were authorized (European Commission Deliberate Releases and placing on the EU market of Genetically Modified Organisms (GMOs)). 
notifications), whereas EU approvals can on average take more than three times as long (average of 102 days).

Table 7: US and EU field test authorizations for GM plants (1991-2005)

\begin{tabular}{|c|c|c|c|c|}
\hline & $\begin{array}{l}\text { Number of } \\
\text { applications }\end{array}$ & $\begin{array}{c}\text { Number of } \\
\text { authorizations }\end{array}$ & $\begin{array}{l}\text { Number of non- } \\
\text { authorized } \\
\text { applications* }\end{array}$ & $\begin{array}{l}\text { Average number of } \\
\text { days elapsed } \\
\text { between application } \\
\text { and authorization }\end{array}$ \\
\hline \multicolumn{5}{|c|}{ US regulation of field trials (plants) } \\
\hline $\begin{array}{l}\text { APHIS field test } \\
\text { permits } \\
\text { (excluding pending) }\end{array}$ & 1,022 & 865 & $\begin{array}{r}157 \\
(15 \%)\end{array}$ & $75^{*}$ \\
\hline $\begin{array}{l}\text { APHIS field test } \\
\text { notifications } \\
\text { (excluding pending) }\end{array}$ & 10,400 & 9,841 & $\begin{array}{r}559 \\
(6 \%)\end{array}$ & $30 *$ \\
\hline $\begin{array}{l}\text { Total APHIS (field test } \\
\text { permits plus } \\
\text { notifications) }\end{array}$ & 11,422 & 10,706 & $\begin{array}{r}716 \\
(6 \%)\end{array}$ & $\begin{array}{r}34 \\
\text { Weighted average } \\
30 * 0.92+75 * 0.08\end{array}$ \\
\hline \multicolumn{5}{|c|}{ EU regulation of field trials (plants) } \\
\hline $\begin{array}{l}\text { Part B of Dir. 90/220 } \\
\text { (1991-2002) and Dir. } \\
2001 / 18 \text { (2002-2005) }\end{array}$ & 1,982 & $\begin{array}{r}97 \% \\
(767 \text { of } 789 \\
\text { known outcomes) }\end{array}$ & $\begin{array}{r}3 \% \\
(22 \text { of } 789 \\
\text { known outcomes) }\end{array}$ & 102 days* \\
\hline
\end{tabular}

* average determined on the basis of a randomly selected sample of authorizations.

From this investigation, it appears that the regulation of GM plant field tests is more permissive in the US than it is in the EU in overall terms, but not for every individual aspect. Taken together, US permit applications and notifications are more numerous and faster than Part B notifications. Rejection rates, however, are similar, with EU rates somewhat lower according to the data available. It is worth noting that the US notification system is highly flexible, fast and almost "automated" in comparison with the EU's Part B procedure. The US notification procedure is a response to, but also an encouragement for, continuing high numbers of applications to conduct field tests with GM plants.

\subsection{Regulating commercialization}

In the United States, FDA is the key agency for the commercialization phase of a GM product, but APHIS and EPA also have important roles to play. In the case of the EU, commercialization is governed by EP and Council Directive 
2001/18's Part C regulating the "placing on the market of GMOs" (European Parliament/Council of the European Union 2001) and by EP and Council Regulation 1829/2003 on food and feed (European Parliament/Council of the European Union 2003a).

\section{APHIS: nonregulated status}

After completing the appropriate field tests with APHIS permits or notifications, developers wishing to commercialize a GM food or crop generally submit a petition to APHIS to request a "determination of nonregulated status" (7 CFR 340.6). A "nonregulated" GM food or crop no longer requires USDA oversight. About one quarter of nonregulated GM foods and crops are GM corn varieties, followed by tomatoes (about one fifth), and various other crops, in particular cotton, oilseed rape, soybeans, and potatoes (see Figure 10). The two traits most often present are herbicide tolerance and insect resistance.

Figure 10: APHIS nonregulated GM crops, by type of crop (May 2005)

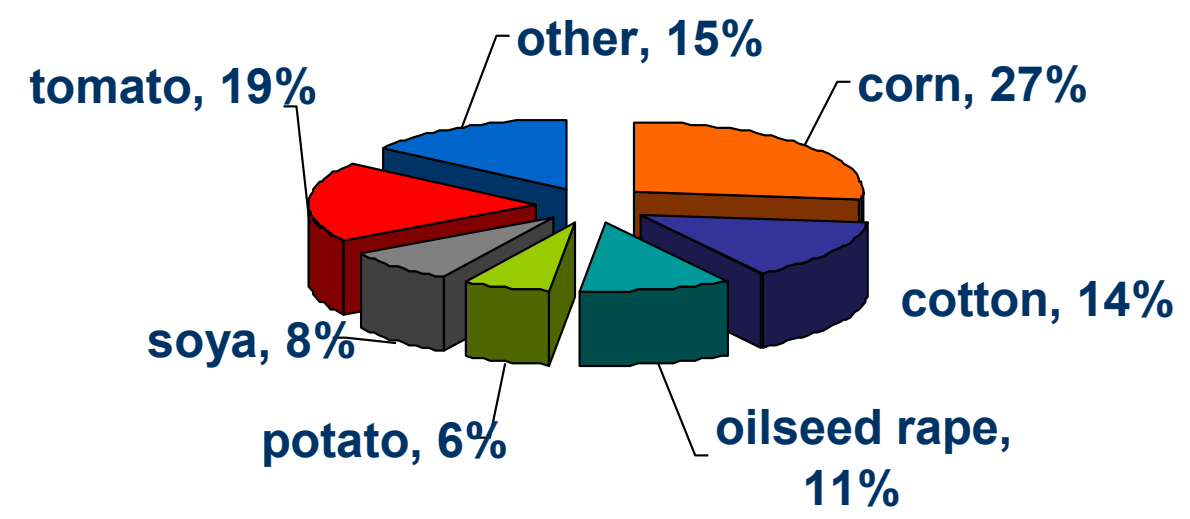

Source: Animal and Plant Health Inspection Service (APHIS) Biotechnology Permits Database (May 2005)

\section{EPA: PIP registration and tolerance level exemption}

In addition to being approved by APHIS, insect resistant Bt varieties also undergo scrutiny by EPA, which regulates the genetic material inserted into these plants ("plant-incorporated protectant", PIP). Under FIFRA, EPA focuses on the 
distribution, sale and use of pesticides, and requires all pesticides to be registered under a procedure described under Code of Federal Regulations, Title 40, Part 152 (40 CFR 152). In 1994, EPA proposed a regulation that defined the genetic material inserted into insect resistant GM plant varieties as "plant pesticides" to be registered under FIFRA. In 2001, after a lengthy comment period, EPA finalized the rule, creating a regulation explicitly for "plant-incorporated protectants" (PIPs), a new name for "plant pesticides" (Code of Federal Regulations, Title 40, Part 174 (40 CFR 174). ${ }^{77}$ This regulation defines a plantincorporated protectant as a "pesticidal substance that is intended to be produced and used in a living plant, or in the produce thereof, and the genetic material necessary for production of such a pesticidal substance" (40 CFR 174.3). As a result, EPA regulates the protein and genetic material inserted into Bacillus thuringiensis (Bt) GM plant varieties as a PIP, while APHIS regulates the plant as a plant pest.

In addition, since its creation in 1970, EPA has had a mandate under section 408 of the FFDCA to determine tolerance levels for pesticide residues when the pesticide appears in food or feed ${ }^{78}$. The FFDCA establishes that "any pesticide chemical residue in or on a food shall be deemed unsafe [...]", and that tolerances may be set and exemptions granted for this type of residue (United States Code, Title 21, Chapter 9, paragraph 346a - 21 USC 346a).

EPA can exempt a pesticide from the need to establish a residue tolerance when there is a reasonable certainty that it will cause no harm. To date, all registered PIPs have been granted an exemption from the requirement of residue tolerance on the grounds that they are not harmful to human or animal health.

\section{FDA: voluntary consultation and no labeling rules}

FDA's role is to ensure the safety of foods and drugs that enter the marketplace. Its main regulatory tools for GM foods are the FFDCA (United

\footnotetext{
${ }^{77}$ Because 40 CFR 174 contains confidential business information and/or because some of its sections are still being elaborated by EPA, only a few of its sections are accessible to the public (last verification: 30 January 2006). Therefore, the information used in this chapter to analyze EPA regulation is only partial, and the comparisons I make draw mainly on the cases of APHIS and FDA who offer more complete information and data.

${ }^{78}$ Before 1970, FDA performed this task.
} 
States Code, Title 21, Chapter 9, §301 et seq.) and its 1992 policy statement on new plant varieties (Food and Drug Administration 1992). FDA treats GM food just like any other food, paying special attention to its product characteristics and intended use. History and experience have led US legislators to expect food to be safe as a general rule. Accordingly, the FFDCA does not give FDA authority to systematically review all foods, and consequently all GM foods, prior to their being placed on the market. Instead, it grants FDA a wide post-market enforcement mandate to intervene if a product is discovered to be "adulterated"79. In the case of food in general, including GM food, FDA places the main responsibility on the food producer to ensure that products on the market are safe. Karin Ricker and Edmundo Garcia of FDA explain the logic behind this principle:

"FDA does not require specific methods or tests, because each product is different and different tests or methods may be required to assess product safety. This approach allows for more flexibility and assures that adequate methods are used in each case. By law, a company or manufacturer is responsible for the safety of products the company markets in the US" (interview with Karin Ricker and Edmundo Garcia, Jr., Food and Drug Administration, 10 June 2004, Washington, DC [District of Columbia]).

Food additives represent an exception to the rule that foods and therefore GM foods shall not be systematically reviewed before marketing. The FFDCA states that by default, "[a] food additive shall $[\ldots]$ be deemed to be unsafe $[\ldots]$ ", that is, the producer must prove that additives are not unsafe before they are marketed (21 USC 348(a)). FDA has tentatively classified insertions of genetic material through genetic engineering as potential food additives that would require review. Many of these food additives, however, fall under FDA's Generally Recognized as Safe (GRAS) definition, and can therefore be exempted from pre-market review through a GRAS notice, consisting of a letter to FDA explaining why a specific additive should be classified as GRAS. As a reaction to growing public questions regarding GM foods, FDA published a proposed rule in 1994 that would make premarket submission of product information mandatory

\footnotetext{
${ }^{79}$ Under 21 USC 342.a.1, a food shall be deemed "adulterated" if it "bears or contains any
} poisonous or deleterious substance which may render it injurious to health". 
120 days prior to marketing. No corresponding final rule has been published (Food and Drug Administration 2001b).

FDA has, however, made a concession to mounting public concerns by encouraging product developers to conduct voluntary consultations. Both its 1992 Statement of Policy (Food and Drug Administration 1992) and 1997 "Guidance on Consultation Procedures" (Food and Drug Administration 1997) have set out guidelines for consultation. The 1992 document offers a decision tree on how to decide whether or not to consult with FDA, and the 1997 document provides an overview of the voluntary consultation process, which essentially consists of an initial and a final consultation. During an initial consultation, pertinent unresolved issues are identified, and a final consultation include the submission of data on these issues to FDA. At the end of the consultation process, FDA sends food developers a letter, usually stating that it has no further questions and reminding them of their continued responsibility to ensure that foods marketed are "safe, wholesome, and in compliance with all applicable legal and regulatory requirements" (Food and Drug Administration List of Completed Consultations on Bioengineered Foods). In practice, all food product developers intending to market a GM food or crop consult FDA in order to get an informal stamp of approval. Between 1994 and 2004, there have been 64 consultations, with exceptionally few from 1999 to 2003, perhaps in connection with the de facto EU moratorium (Figure 11). Figure 12 shows a breakdown by type of crop. 
Figure 11: Completed FDA consultations on GM food, 1994-2004

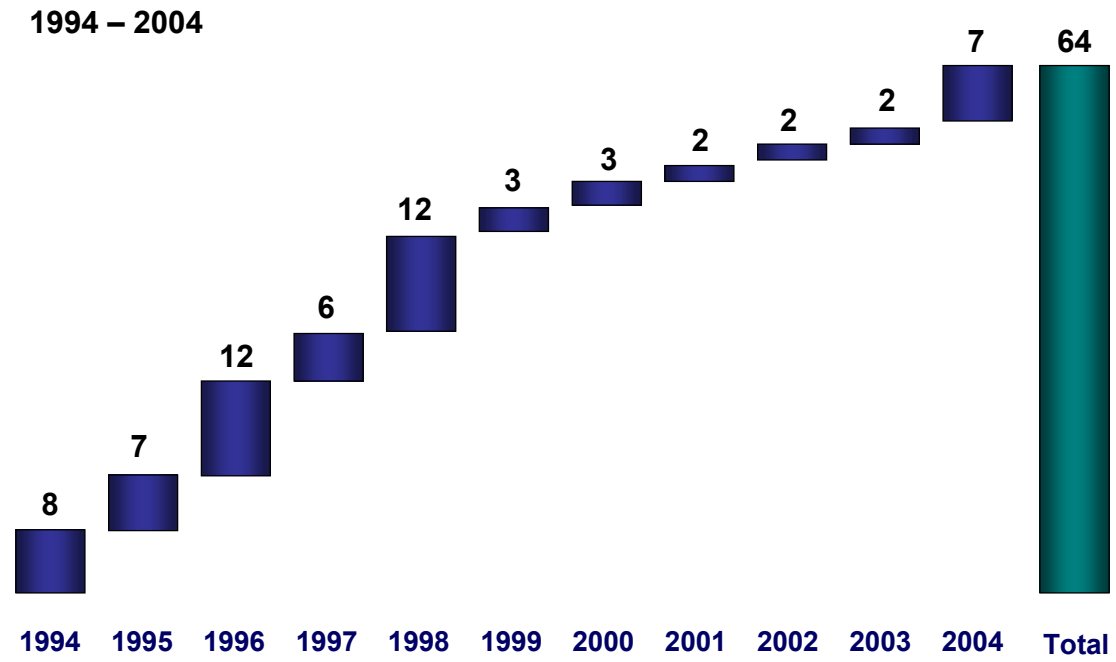

Source: Food and Drug Administration - List of Completed Consultations on Bioengineered Foods (May 2005)

Figure 12: Completed FDA consultations by type of GM food, 1994-2005

Total: 66 completed consultations by May 2005

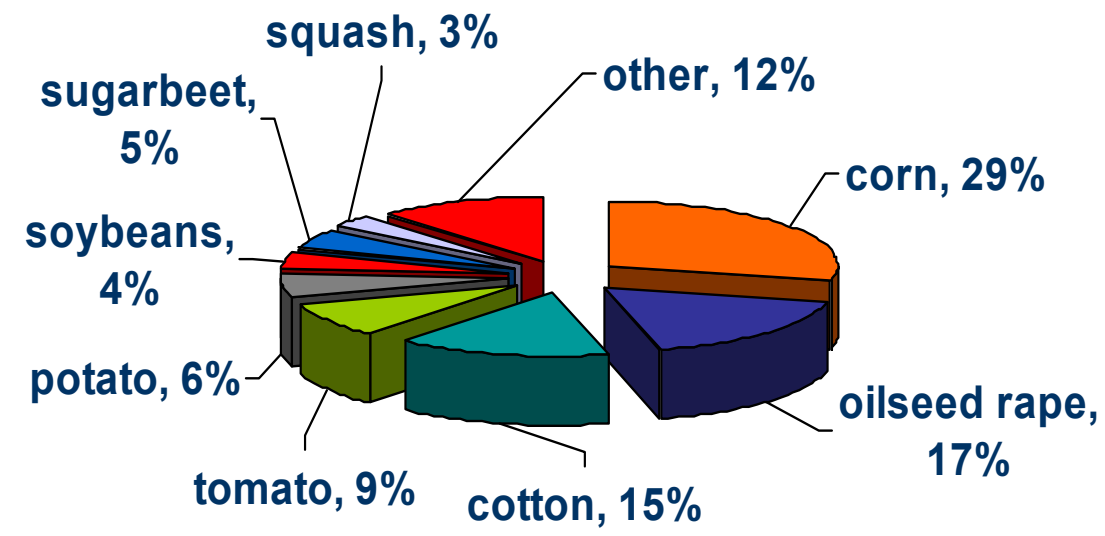

Source: Food and Drug Administration - List of Completed Consultations on Bioengineered Foods (May 2005)

US regulation does not require GM foods and ingredients to be labeled or traced. Policy documents discuss the issue of labeling and why it should not be applicable to GM foods, and make no mention of traceability. The FFDCA gives FDA a mandate to prohibit the entry into interstate commerce of "misbranded" 
foods, i.e. foods bearing false or misleading labels. Specifically, it requires that a food producer describe a product by its common name and reveal important facts associated with it (US Code, Title 21, §343). FDA interprets the FFDCA's mandate as not giving it any authority to require the labeling of a GM food as long as the final product is considered safe.

If there is something tangibly different about a novel food, such that the common name could no longer be used, FDA requires the food label to bear a name other than the conventional name, informing the consumer of the altered composition of a food. For GM foods, this condition usually does not apply. ${ }^{80}$ Under no circumstances would FDA mandate the labeling of a food as "genetically modified", "genetically engineered" or a similar denomination. As put by Ricker and Garcia of FDA,

"FDA has no legal authority to require labeling because a production process is different. There is no need for biotech crops as a class to be labeled. Labeling is mandated only if a product is materially different or if it raises health issues. For example, the presence of an unexpected allergen would warrant labeling" (interview with Karin Ricker and Edmundo Garcia, Jr., Food and Drug Administration, 10 June 2004, Washington, $\mathrm{DC})$.

In January 2001, FDA launched a procedure to explore the idea of introducing voluntary labeling as a reaction to consumers' growing concerns (Food and Drug Administration 2001a). This document, however, is a reiteration of the standpoint that labeling of GM food is not necessary because "the use of bioengineering is not a material fact" (Food and Drug Administration 2001a: 4840). The document enumerates several cases which affect labeling: significant difference from the traditional counterpart, significantly different nutritional composition, or presence of a food allergen that a consumer would not expect (Food and Drug Administration 2001a: 4839). The document further suggests that manufacturers wishing to use voluntary labeling should avoid using terms such as "GM free" or "biotech free"; since it is impossible to exclude adventitious

${ }^{80}$ One example where it did apply is the case of soybeans produced by DuPont to have an increased oleic acid content compared to conventional soybeans. FDA required soybean oil made from this GM soybean to be labeled as "High Oleic Soybean Oil" in order to inform consumers of its changed nutritional composition. 
presence of GM material in food, such labeling would be misleading (Food and Drug Administration 2001a: 4840). So far, there has been no follow-up to the draft guidance document on voluntary labeling.

\section{EU: Part C notification and/or 1829/2003 procedure; strict labeling rules}

In the European Union, applicants wishing to place a GM food on the market have the choice of submitting an application exclusively under EP and Council Regulation 1829/2003 on GM food and feed, or under Part C of 2001/18 (for the deliberate environmental release part) and 1829/2003 (for the food part) (European Parliament/Council of the European Union 2003a, Preamble 33).

Part C of EP and Council Directive 2001/18 covers the "placing on the market" of GMOs, defined as "making available to third parties, whether in return for payment or free of charge" (European Parliament/Council of the European Union 2001, art. 2.4) and succeeds Council Directive 90/220. Commercial cultivation, import and selling to food processors are examples of "placing on the market". A GMO or combination of GMOs to be placed on the market must be submitted to the national competent authority of the country where the GMO is to be first introduced. The competent authority forwards the full notification (not merely the summary, as for Part B notifications) to the Commission, which in turn sends it to all EU Member States. The competent authority prepares an assessment report, which is transmitted to the Commission and competent authorities of the other Member States. These actors may comment on the report. If there is no objection by Member States or the Commission, the authorization is granted by the national competent authority.

In the case of an objection by one or several Member States (via the competent authorities) or by the Commission, the comitology rules laid down in article 5 of Council Decision 1999/468 apply (Council of the European Union 1999a). A regulatory committee, composed of Member State representatives, deliberates on a draft submitted by the Commission. If the Committee approves the draft by a qualified majority, the Commission adopts the measures proposed. If, however, the regulatory committee rejects the draft or does not express an 
opinion, the Commission submits the proposal to the Council. If the Council opposes the proposal by a qualified majority, the Commission reexamines it and may submit an altered proposal. If the Council neither adopts nor opposes the proposal, then the European Commission adopts the proposed act. ${ }^{81}$

GM food, food containing GMOs and food produced from or containing GMOs are subject to EP and Council Regulation 1829/2003 (European Parliament/Council of the European Union 2003a), which in 2004 succeeded EP and Council Regulation 258/97 (European Parliament/Council of the European Union 1997). Important changes were introduced by this new Regulation on GM food and feed. In particular, Regulation 1829/2003 foresees a single authorization procedure ("one door - one key") for all food and feed containing GMOs, and gives the European Food Safety Agency (EFSA) a central role. Competent authorities send applications to EFSA, and EFSA has the duty of informing the Commission, other Member States, and the public. EFSA then prepares an opinion, using the environmental risk assessment criteria developed in Directive 2001/18 (European Parliament/Council of the European Union 2001), and sends it on to the Commission, Member States and the applicant. On the basis of this opinion, the Commission submits a draft decision to the Standing Committee on the Food Chain and Animal Health (a regulatory committee created in 2002, consisting of Member State representatives). If the Committee agrees with the Commission's draft decision, it is adopted. If not, the Commission submits a proposal to the Council, to which the procedures laid down in 1999/468 apply, as described above for Directive 2001/18.

The issue of GM food labeling stood at the center of the European GM food debate for several years in late 1990s and until 2003, when the issue was newly addressed under Regulations $1829 / 2003$ and $1830 / 2003$. In the EU, it is

${ }^{81}$ This rule can easily lead to the impression that the European Commission takes decisions on GMO authorizations in an undemocratic manner, and that it is biased in favour of agricultural biotechnology since it has a track record of approving contested products. Friends of the Earth Europe notes that "the Commission has a lot of power in taking decisions on GMO authorizations because of comitology rules [and] this has contributed to undermining public support for GMOs" (interview with Geert Ritsema and Carmen Olmedo, Friends of the Earth Europe, 3 September 2004, Brussels).

In response to this type of criticism, Rene von Schomberg, a scholar on the GMO debate, instead affirms that faced with a situation of "paralysis in the EU decision-making process since mid1998 between Member States, the Commission [merely] takes its assigned role [... of taking decisions] in response to the absence of a qualified majority in the regulatory committee" (interview with Rene von Schomberg, European Commission, 2 September 2004, Brussels). 
supposed that consumers should have the right to know whether a food product they purchase is genetically modified or contains genetically modified ingredients. Labeling of GM foods was first made mandatory under EP and Council Regulation 258/97 concerning Novel Foods and Novel Food Ingredients (European Parliament/Council of the European Union 1997). Since this regulation did not cover all GM foods, a further regulation was added to complement it. Council Regulation 1139/98 (Council of the European Union 1998) required the labeling of foods containing herbicide tolerant GTS40/3/2 soybeans and insect resistant and herbicide tolerant Bt176 corn, two GM crops approved under 90/220 before the Novel Foods Regulation was passed. Commission Regulation 49/2000 settled the much-debated threshold issue, making labeling mandatory above a $1 \%$ adventitious (i.e. accidental) GM-content of individual food ingredients (European Commission 2000a).

Under the new regulations, these provisions have changed somewhat. Regulation 1829/2003 of 2003, in force since 18 April 2004, lowers the adventitious presence threshold to $0.9 \%$ for individual GM food ingredients. It also newly introduces the same labeling requirement for GM feed as for GM food (art. 12 and 24). Regulation 1829/2003 further applies to products consisting of or containing GMOs, as well as food and feed produced from GMOs (art. 2), for the first time including products that no longer contain detectable traces of GMOs (e.g. highly refined oils and syrups). Article 4 establishes the exact wording that should appear on the labels in these different cases, both for products deriving from within and imported from outside the European Union.

Regulation 1830/2003 also addresses the issue of "traceability", which is defined as "the ability to trace GMOs and products produced from GMOs at all stages of their being placed on the market through the production and distribution chains" (art. 3.3). Article 4 determines that products consisting of or containing GMOs must be transmitted to the receiving food chain operator with the information that they contain or consist of GMOs, and with a "unique identifier", a "code which serves to identify a GMO [...]". This information must be transferred throughout the food chain. Operators must set up standardized procedures to implement traceability requirements, and must keep records of each transaction for five years. 


\section{Comparing $U S$ and $E U$ regulations for commercialization and their outputs}

Comparing US and EU commercialization regulations reveals a much more restrictive procedure in the EU than in the US, especially if EU Member States disagree (see Table 8$).{ }^{82}$

On average, the EU foresees more regulatory steps than the US. USDA's petition for nonregulated status involves four steps, and the FDA's voluntary consultation procedure foresees three informal steps. EU procedures include four to eight steps under Dir. 2001/18, and seven to nine under Reg. 1829/2003, depending on whether or not there is disagreement among Member States and whether or not the Commission has to resort to comitology. In recent approval processes, disagreements have routinely resulted in a maximum number of steps.

The time foreseen for authorizations is also greater in the EU than in the US. APHIS responds to the petition for nonregulated status within 180 days. The FDA has no stated time provisions since the process is informal and voluntary. An EU approval under Dir. 2001/18 should take a maximum of 225 days, and 270 are possible for authorization under Reg. 1829/2003, but prolongation is possible if the Council becomes involved. As for expiration, USDA nonregulated status is "forever", as is FDA's "stamp of approval" in an unofficial way. EU consent under Part C and authorization under 1829/2003 are granted for ten years, and may be renewed (art. 17). Accordingly, EU approvals are subject to postcommercialization monitoring and reporting, whereas in the US, commercialized products are no longer subject to regulatory oversight. Finally, labeling and traceability are important restrictions in the EU, which are nonexistent in the US.

\footnotetext{
${ }^{82}$ USDA, FDA and EU rules and regulations form the basis for this comparison.
} 
Table 8: US and EU regulation of GM product commercialization (as of 1 Aug. 2005)

\begin{tabular}{|c|c|c|c|c|}
\hline & \multicolumn{2}{|c|}{ US regulation of commercialization } & \multicolumn{2}{|c|}{ EU regulation of commercialization } \\
\hline & $\begin{array}{c}\text { APHIS } \\
\text { nonregulated } \\
\text { status }\end{array}$ & $\begin{array}{c}\text { FDA } \\
\text { voluntary } \\
\text { consultation }\end{array}$ & $\begin{array}{l}\text { EP/Council Directive } \\
\text { 2001/18 Part C }\end{array}$ & $\begin{array}{c}\text { EP/Council Regulation } \\
1829 / 2003\end{array}$ \\
\hline $\begin{array}{l}\text { Regulatory } \\
\text { steps foreseen }\end{array}$ & $\begin{array}{l}\frac{4 \text { steps: }}{\text { 1. filing of }} \\
\text { petition } \\
\text { 2. preliminary } \\
\text { review for } \\
\text { completeness } \\
\text { 3. publishing of } \\
\text { notice/ } \\
\text { comment } \\
\text { period } \\
\text { 4. response }\end{array}$ & $\begin{array}{l}\text { 3 steps: } \\
\text { 1. initial } \\
\text { consultation } \\
\text { 2. final } \\
\text { consultation } \\
\text { 3. letter }\end{array}$ & $\begin{array}{l}\text { 4-8 steps: } \\
\text { 1. notification to } \\
\text { competent authority } \\
\text { 2. assessment report by } \\
\text { competent authority } \\
\text { 3. comment period for } \\
\text { Commission and } \\
\text { Member States } \\
\text { 4. Answer } \\
\text { Further possible steps: } \\
\text { 4. Commission } \\
\text { submission to } \\
\text { regulatory committee } \\
\text { 5. deliberation within } \\
\text { regulatory committee } \\
\text { and result } \\
\text { 6. proposed decision by } \\
\text { Commission (if step } 5 \\
\text { is inconclusive) } \\
\text { 7. deliberation within } \\
\text { Council and vote by } \\
\text { qualified majority } \\
\text { 8. Commission decision } \\
\text { (if no position } \\
\text { adopted under } 7 \text { ) }\end{array}$ & $\begin{array}{l}\text { 7-9 steps: } \\
\text { 1. application to } \\
\text { competent authority } \\
\text { 2. competent authority } \\
\text { acknowledges and } \\
\text { forwards application to } \\
\text { EFSA } \\
\text { 3. EFSA forwards } \\
\text { application to Member } \\
\text { States and publicizes it } \\
\text { 4. EFSA drafts opinion } \\
\text { and forwards it to } \\
\text { Commission and } \\
\text { Member States } \\
\text { 5. Commission drafts } \\
\text { decision and submits it } \\
\text { to Standing Committee } \\
\text { on the Food Chain and } \\
\text { Animal Health } \\
\text { 6. deliberation within } \\
\text { Standing Committee } \\
\text { on the Food Chain and } \\
\text { Animal Health and } \\
\text { result } \\
\text { 7. answer } \\
\text { Further possible steps: } \\
\text { 7. proposed decision by } \\
\text { Commission (if step } 6 \\
\text { inconclusive) } \\
\text { 8. deliberation within } \\
\text { Council and vote by } \\
\text { qualified majority } \\
\text { 9. Commission adopts } \\
\text { decision if no position } \\
\text { adopted under } 8\end{array}$ \\
\hline $\begin{array}{l}\text { Time } \\
\text { foreseen for } \\
\text { authorization }\end{array}$ & 180 days & not applicable & 225 days & 270 days \\
\hline $\begin{array}{l}\text { Expiration of } \\
\text { authorization }\end{array}$ & none & none & $\begin{array}{l}10 \text { years } \\
\text { (renewable) }\end{array}$ & $\begin{array}{l}10 \text { years } \\
\text { (renewable) }\end{array}$ \\
\hline $\begin{array}{l}\text { Reporting, } \\
\text { monitoring, } \\
\text { other } \\
\text { restrictions }\end{array}$ & none & none & $\begin{array}{ll} & \text { reporting } \\
\text { - } & \text { monitoring } \\
\text { - } & \text { information to the } \\
& \text { public } \\
\text { - } & \text { strict labeling rules }\end{array}$ & $\begin{array}{l}\text { - } \text { reporting } \\
\text { - monitoring } \\
\text { - information to the } \\
\text { public } \\
\text { - } \text { strict labeling rules } \\
\text { - } \text { traceability } \\
\text { requirements }\end{array}$ \\
\hline
\end{tabular}

Data on actual GM food and crop commercialization confirms the impression given by rules and regulations: the US receives more applications, grants more authorizations, as boasts fewer non-authorized products than the 
EU. ${ }^{83}$ In addition, on average, a GM product commercialization takes significantly longer in the EU than it does in the US (Table 9).

Since 1992, when the first nonregulated status was granted to Calgene's Flavr Savr tomato, APHIS has received 103 petitions for nonregulated status (including pending ones), of which it has granted 65.38 petitions or about $37 \%$ have not led to nonregulated status or, in the case of pending petitions, have not yet led to it yet. Many of these are withdrawals. At FDA, 98 initial consultations have taken place, and 66 products have been given the FDA's "stamp of approval" after a final consultation, whereas 32 (33\%) have been withdrawn. Together, APHIS and FDA have overseen 201 authorization/consultation procedures, 131 of which (65\%) have been approved, and $70(35 \%)$ of which have not. About 65 different GM products have been authorized for commercialization in the US.

In the EU, 18 GMOs out of 33 were approved under 90/220, of which 10 are food and feed crops. Under EP and Council Directive 2001/18, 16 notifications so far have led to two approvals (NK603 and MON 863, both GM corn varieties). Under EP and Council Regulation 258/97, 13 out of 18 novel foods were approved, and 18 are awaiting approval under the new EP and Council Regulation 1982/2003 (including some transferred from Reg. 258/97. In summary, in the EU, out of 85 applications, 25 (or 29\%) have been approved, while 60 (or $71 \%$ ) are pending or have been withdrawn. About 18 different products are currently approved in the EU, most of which are corn, oilseed rape, soybean, and cotton varieties.

A notable difference can be found between the average number of days that elapse between application and authorization in the EU and the US. APHIS petitions are dealt with within an average of 221 days, and FDA consultations take an average of 252 days. This makes for a combined average of 237 days. In contrast, EU approvals for commercialization take an average of 794 days or 2.2 years.

\footnotetext{
${ }^{83}$ In the case of the EU, applicants anticipating potential rejection may be more reluctant than their US counterparts to submit products for approval.
} 
Table 9: US and EU GM food and crop commercialization (1991-2005)

\begin{tabular}{|c|c|c|c|c|}
\hline & $\begin{array}{c}\text { Number of } \\
\text { applications }\end{array}$ & $\begin{array}{c}\text { Number of } \\
\text { authorizations }\end{array}$ & $\begin{array}{l}\text { Number of non- } \\
\text { authorized } \\
\text { applications* }\end{array}$ & $\begin{array}{c}\text { Average number } \\
\text { of days elapsed } \\
\text { between } \\
\text { application and } \\
\text { authorization }\end{array}$ \\
\hline \multicolumn{5}{|c|}{ US regulation of commercialization } \\
\hline APHIS nonregulated status & 103 & $\begin{array}{r}65 \\
(63 \%)\end{array}$ & $\begin{array}{r}38 \\
(37 \%)\end{array}$ & $\begin{array}{r}221 \\
\text { (7.4 months) }\end{array}$ \\
\hline $\begin{array}{l}\text { FDA voluntary consultation } \\
\text { (none pending) }\end{array}$ & 98 & $\begin{array}{r}66 \\
(67 \%)\end{array}$ & $\begin{array}{r}32 \\
(33 \%)\end{array}$ & $\begin{array}{r}252 \\
\text { (8.4 months) }\end{array}$ \\
\hline Total US & 201 & $\begin{array}{r}131 \\
(65 \%)\end{array}$ & $\begin{array}{r}70 \\
(35 \%)\end{array}$ & $\begin{array}{r}237 \\
\text { (7.9 months) }\end{array}$ \\
\hline \multicolumn{5}{|c|}{ EU regulation of commercialization } \\
\hline $\begin{array}{l}\text { Council Dir. 90/220 } \\
\text { Part C }\end{array}$ & 33 & $\begin{array}{r}10 \\
(30 \%)\end{array}$ & $\begin{array}{r}23 \\
(70 \%)\end{array}$ & $\begin{array}{r}629 \text { days } \\
\text { (20.7 months } \\
1.7 \text { years) }\end{array}$ \\
\hline $\begin{array}{l}\text { EP/Council 2001/18 } \\
\text { Part C }\end{array}$ & 16 & $\begin{array}{r}2 \\
(13 \%)\end{array}$ & $\begin{array}{r}14 \\
(87 \%)\end{array}$ & $\begin{array}{r}1052 \text { days } \\
\text { (35.1 months } \\
2.9 \text { years) }\end{array}$ \\
\hline EP/Council Reg. 258/97 & 18 & $\begin{array}{r}13 \\
(72 \%)\end{array}$ & $\begin{array}{r}5 \\
(28 \%)\end{array}$ & $\begin{array}{r}1923 \text { days** } \\
\text { (64 months } \\
5.2 \text { years) }\end{array}$ \\
\hline EP/Council Reg. 1829/2003 & 18 & $\begin{array}{r}0 \\
(0 \%)\end{array}$ & $\begin{array}{r}18 \\
(100 \%)\end{array}$ & not applicable \\
\hline EU Total & 85 & $\begin{array}{r}25 \\
(29 \%)\end{array}$ & $\begin{array}{r}60 \\
(71 \%)\end{array}$ & $\begin{array}{r}794 \text { days } \\
\text { (26.5 months } \\
2.2 \text { years) }\end{array}$ \\
\hline
\end{tabular}

** figure based on data for 1 out of 13 authorizations (data for others not available)

As for labeling, in accordance with US regulations, US GM food is not labeled. ${ }^{84}$ Organic food, on the other hand, is often labeled as not containing GMOs since the 2002 US National Organic Program Standards include genetic engineering as one of the methods not classified as "organic". ${ }^{85}$

${ }^{84}$ On the topic of labeling in the US and the EU, Beate Kettlitz of the European Consumers' Organisation remarks that "In Europe, labeling is meant to inform consumers. In the US, labels usually warn against something. That is a big difference in labeling strategy" (interview with Beate Kettlitz and Patrick Sutton, European Consumers' Organisation, 14 September 2004, Brussels).

${ }^{85}$ The Organic Foods Production Act (OFPA) of 1990 required the US Department of Agriculture to develop national standards for organically produced agricultural products. These standards came into force in 2002. A food labeled "organic" in the US must be produced without conventional pesticides, fertilizers made with synthetic ingredients, genetic engineering or ionizing radiation. Observers of the GM food debate recount that the decision to add genetic engineering to the national organic standards was controversial. Proponents of genetic 
In the EU, as a result of strict EU labeling rules, labeled GM foods are almost as scarce as in the US, and a comprehensive list of labeled products does not exist. As mentioned earlier, several national and international organizations have nevertheless attempted to establish what labeled GM products are in circulation through specific initiatives. For example, Greenpeace International's “Trolley Watch", referred to in Chapter 2, has turned up around 70 labeled GM foods. These include oils and margarines, soy products such as tofu and soy sauce, and processed foods including cake mixes and snack foods. The GM ingredients contained in these foods are mostly GM soy (in over half of the products) and some GM corn. The citizens reporting to "Trolley Watch" are mainly based in Germany (around 30\%), the Netherlands, France (around 20\% each), the Czech Republic (ca. 15\%), Slovakia, Belgium and the U.K. (Greenpeace International Trolley Watch. GE Food in Europe).

\subsection{Conclusion}

As this chapter has shown, US and EU regulations in the field of GM food are based on very different regulatory frameworks and rules. Table 10 provides a summary of main differences. A systematic comparative look at GM food and crop rules and regulations, as well as the actual outcomes of these rules confirm a relatively permissive regulatory situation in the US, and a relatively restrictive EU regulatory system.

In the US, three federal agencies regulate agricultural biotechnology under a series of existing statutes that do not regulate biotechnology explicitly. In contrast, in the EU, laws and regulations were devised specifically for GMOs. The US approach results in a relatively flexible and adaptable authorization

engineering felt that it would make GM foods seems "un-organic", i.e. bad for the environment, which they argued was misleading since one of the possible benefits of genetic engineering is the reduction of pesticide use. GM food critics, on the other hand, saw the standards as a chance for GM foods to be excluded from a category of produce that they perceived as superior. Some observers of the debate suggest that the decision to include genetic engineering in the standards was partly a move to justify the US's policy of not labeling GM foods: consumers who wanted to buy GM free food could now buy organic food.

The European Union also links the non-use of genetic engineering and organic production methods. In 1999, Council Regulation 2092/91 of 1991 (Council of the European Union 1991) on organic production of agricultural products was amended to exclude the use of genetically modified organisms "in order to maintain consumer confidence" in such production (Cardwell 2004: 285-6). 
process, whereas the EU displays more clear-cut rules that are consistently binding for all GMOs.

The US and the EU display varying authorization procedures at both the development and commercialization stages. In the US, a GM crop that passes the field testing phase naturally flows on into the commercialization process. In the European Union, a GMO to be placed on the market after a field test must go through a second similar but more demanding authorization process. Labeling and traceability are not foreseen in the US regulatory framework while they are mandatory in the EU.

Table 10: US and EU regulatory differences

\begin{tabular}{|c|c|c|}
\hline & United States & European Union \\
\hline $\begin{array}{l}\text { Type of regulatory } \\
\text { framework }\end{array}$ & Not specific to GM foods/crops & Specific to GM foods/crops \\
\hline Institutions & $\begin{array}{l}\text { White House/Office of Science and } \\
\text { Technology Policy (OSTP) } \\
\text { US Department of Agriculture's Animal and } \\
\text { Plant Health Inspection Service (APHIS) } \\
\text { Environmental Protection Agency (EPA) } \\
\text { Food and Drug Administration (FDA) } \\
\text { US states }\end{array}$ & $\begin{array}{l}\text { European Commission } \\
\text { European Parliament } \\
\text { Council of the European Union / Member } \\
\text { States } \\
\text { European Food Safety Agency (EFSA) } \\
\text { Member States (crucial for implementation) }\end{array}$ \\
\hline Legal basis & $\begin{array}{l}\text { Constitution of the United States (art. I.8) } \\
\text { Plant Protection Act (PPA) } \\
\text { Federal Insecticide, Fungicide, and } \\
\text { Rodenticide Act (FIFRA) } \\
\text { Federal Food, Drug, and Cosmetic Act } \\
\text { (FFDCA) } \\
\text { Code of Federal Regulations, Title 7, Part } 340 \\
\text { Code of Federal Regulations, Title 40, Parts } \\
\text { 152, } 174 \\
\text { Other policy documents (OSTP, FDA) }\end{array}$ & $\begin{array}{l}\text { Treaty establishing the European Community } \\
\text { (consolidated text, art. 95) } \\
\text { EP/Council Directive } 2001 / 18 \\
\text { EP/Council Regulation } 1829 / 2003 \\
\text { EP/Council Regulation } 1830 / 2003\end{array}$ \\
\hline Field testing & $\begin{array}{l}\text { APHIS permits and notifications } \\
\text { EPA permits for Bt crops }\end{array}$ & $\begin{array}{l}\text { Notification procedure under Part B of } \\
\text { EP/Council Directive 2001/18 }\end{array}$ \\
\hline $\begin{array}{l}\text { Commer- } \\
\text { cialization }\end{array}$ & $\begin{array}{l}\text { APHIS nonregulated status } \\
\text { EPA regulation of "plant-incorporated } \\
\text { protectants" (PIPs) } \\
\text { EPA tolerance level exemption } \\
\text { FDA voluntary consultation }\end{array}$ & $\begin{array}{l}\text { Notification procedure under Part C of } \\
\text { - EP/Council Directive 2001/18 } \\
\text { and/or } \\
\text { - EP/Council Regulation 1829/2003 }\end{array}$ \\
\hline Labeling & No requirements & $\begin{array}{l}\text { Requirements under EP/Council Regulation } \\
1830 / 2003\end{array}$ \\
\hline Traceability & No requirements & $\begin{array}{l}\text { Requirements under EP/Council Regulation } \\
1830 / 2003\end{array}$ \\
\hline
\end{tabular}


US and EU regulatory systems seem to have drifted further apart over the past decade. In the United States, core elements of GM food policy have remained largely unchanged. During the 1990s, these elements were reinforced by the introduction of streamlined procedures and opportunities for exemption from oversight. In contrast, the European Union has done away with most possibilities for expedited authorization of GM foods in its new 1829/2003 Regulation on Food and Feed, and requests a more extensive environmental risk assessment under Directive 2001/18 than was the case under Directive 220/90.

Having established how GM food policies are different in the US and the EU, I now turn to the why part of my research question. The next chapter presents the theory and method underlying this dissertation, and develops an analytical framework with which to explain GM food policy differences. 


\section{Theory And Method: Studying GM Food Policy}

I draw on three theoretical approaches to craft a framework ${ }^{86}$ to explain US and EU policy differences in the area of genetically modified food: policy process theory, comparative historical analysis, and science and technology studies (STS). Each of these approaches encompasses a large family of individual theories and methods. From within this wide array of possibilities, I select and assemble different theories, which build on common assumptions and methods, and which together form a coherent and comprehensive analytical tool to explain GM food policy outcomes. This chapter is dedicated to explaining how, together, these theoretical approached have the potential to explain GM food policy differences in all their complexity. I first introduce each approach in terms of its main objects of study and historical development (4.1). I then present the postulates that I draw from them and on which I base my study (4.2). I further discuss relevant methodological questions (4.3) for this dissertation before presenting my analytical framework (4.3).

\subsection{Theory}

Policy process theory, comparative historical analysis, and STS have important similarities which make it possible to combine them in a coherent fashion. At the same time, they focus on different research goals and questions, and thus offer added value to one other. Each family of theories I select contributes an important element to the explanatory framework of this study. Policy process theory deals specifically with explaining policy outcomes, which is precisely this dissertation's focus. Comparative historical analysis is designed to elucidate broad social phenomena through comparison. Comparing regulation,

\footnotetext{
${ }^{86}$ I use the term framework to mean a "[mode] of organizing problems, giving them a form and a coherence" (Parsons 1995: 32). Like policy process theorist Ostrom, I view a framework's role as helping to "identify the elements and relationships among [...] elements" and providing "the most general list of variables that should be used" for analysis. Ostrom distinguishes "frameworks" from "theories" and "models". Theories "focus on a framework and make specific assumptions that are necessary for an analyst to diagnose a phenomenon, explain its processes, and predict outcomes". Models, on the other hand, "make precise assumptions about a limited set of parameters and variables" (Ostrom 1999: 39-40).
} 
especially in a controversial area, falls exactly into this category. STS is a broad approach that aims to understand science and technology issues and developments within their social contexts. GM food policy is a product of science and technology interacting with society, and is therefore the type of empirical field addressed by STS.

While policy process theory and comparative historical analysis constitute the basic toolkit I rely on in order to explain why GM food policies differ, STS serves as a constant reminder of the complexity of GM food policy. It underlines the fact that no framework can deal with a multifaceted issue fully and exhaustively, that it is no more than a tool that helps us understand a complicated world. While my approach is fundamentally positivist ${ }^{87}$ and in search of causal relations, STS helps me to further investigate cognitive ${ }^{88}$ issues and incorporate them into my analysis. ${ }^{89}$

\section{Policy process theory}

The first family of theories that I use is policy process theory ${ }^{90}$. Policy process theory offers theories and methods that are specifically devised to explain policy outcomes. This approach's main interest lies in explaining policy processes and why policies are the way they are. It is positivist and explanatory, assumes causal relationships, and is frequently used to compare policy outcomes. Comparative studies within policy process theory usually seek to explain policy similarities or differences across countries, policy fields, and/or time.

${ }^{87}$ Positivism suggests that phenomena are observable and explainable. Within a positivist approach, reality consists of a world of objectively defined facts, which can be scientifically measured.

${ }^{88}$ The term "cognitive" denotes "mental processes connected with understanding, formulation of beliefs, and acquisition of knowledge, and thus distinct from volitional processes, such as wanting or intending" (definition from Flew 1999).

${ }^{89}$ As will become clear in this chapter, some theories within comparative historical analysis and policy process theory also make prominent use of cognitive elements. Moreover, STS is conscious of causality. The fundamental difference between comparative historical analysis and policy process theory on the one hand, and STS on the other, is that the former analyzes causalities as a method to explain an outcomes, while the latter rejects causality as a way of describing, understanding and explaining the world.

${ }^{90}$ For an overview of policy process theory, see, for example, Héritier 1993, Sabatier 1999a or Parsons 1995. 
Policy process theory developed as a reaction to "public policy studies", a discipline that was widespread in the 1950s and 1960s. ${ }^{91}$ Public policy studies' main aim was to make policy for current decision-making processes, i.e. to construct policy recommendations, in isolation from politics, to be implemented by policy-makers. It developed out of a belief that "the political process was unable to deal creatively with pressing policy problems and that it was inordinately influenced by special interests" (White 1994: 857). Public policy studies were therefore concerned with improving policy-making through rational analysis. Public policy studies were also strongly positivist and devoted to empirical methods. Researchers within this area of study preferred the use of quantitative, quasi-experimental methods mimicking the natural sciences as much as possible, as well as economic tools such as cost-benefit analysis. Their goal and ideal was to develop objective, rational and neutral policy recommendations.

Starting in the 1970s, the area of policy process theory developed out of a new preoccupation with the importance of explanatory analysis of policy as a process. A field dedicated to studying how policy is shaped, policy process theory rejects the idea that policy-making can be objective and neutral, and that policy recommendations can simply be provided by experts and then implemented by policy-makers. A core assumption of many individual policy process theories is that rational analysis, empirical study and economic costbenefit analysis - the traditional ingredients found in policy analysis for decisionmaking - alone do not suffice to understand and explain policy. As expressed by Sabatier, a prominent representative of the field of policy process theory, "the process of public policymaking includes the manner in which problems get conceptualized and brought to government for solution" (Sabatier 1999b: 3).

One of the first policy process models to be developed is the policy cycle or stages heuristic model, which divides the policy-making process into phases, typically agenda-setting, policy formulation, policy decision-making, implementation, and evaluation (see for example Laswell 1956, deLeon 1999). This approach was inspired by Easton and C.O. Jones's input-output-oriented models (Easton 1965, Jones, C.O. 1970). The stages heuristic approach has been

${ }^{91}$ For an overview of public policy studies, a field also referred to as "policy studies", "policy analysis", "public policy analysis", or "policy science", see, for example, Howlett/Ramesh 1995, Lester/Stewart 1996 or Parsons 1995. Laswell (1951) is one of the first and most central figures to describe what he called "policy science". 
widely criticized (e.g. Sabatier 1999b), in particular because it is not a causal model and because it idealizes the policy process by drawing artificial distinctions between individual policy-making phases. This model, however, continues to be used as a valuable tool for describing policy (Parsons 1995: 778 ), and as a way for "viewing and categorizing actors and actions in ways that help unravel and elucidate given policies ..." (deLeon 1999: 26). ${ }^{92}$

More recent theories of the policy process put greater emphasis on describing policy as a dynamic process over time involving multiple actors and events which cannot be neatly divided into policy stages. Aside from the stages heuristic approach, a series of prominent approaches within the large family of policy process theories include (list loosely based on Parsons 1995: 39-40):

- $\quad$ pluralist-elite approaches, which focus on the power distributions among groups and elites;

- rational choice-inspired approaches, based on the assumption that individuals' actions are motivated by specific policy preferences;

- approaches focusing on how policy change occurs: for example, during "windows of opportunity" used by "policy entrepreneurs" or "veto players", or when a policy equilibrium is "punctuated";

- $\quad$ subsystem approaches, which analyze policy activity in specific policy domains with the help of concepts such as "network" or "advocacy coalition";

- $\quad$ post-positivist/constructivist approaches, which examine policy processes in terms of discourse, language and communication;

- institutionalist approaches, which privilege the role of institutions in explaining policy outcomes.

This dissertation uses the Advocacy Coalition Framework (ACF), a subsystem approach which also addresses policy change, developed by Sabatier and Jenkins-Smith $(1993,1999){ }^{93}$

92 The stages heuristic model is not used as an analytical theory in this dissertation. It is a helpful tool, however, to characterize the research focus of this study. Within a classic policy cycle going from agenda-setting to implementation, this dissertation focuses mainly on the policy formulation and decision-making phases. It therefore puts special emphasis on the questions "how is GM food policy shaped?" and "how are policy decisions regarding GM foods taken?". The question of how GM food became a policy issue is also considered to a certain extent (agenda-setting). In the case of the EU, GM food policy implementation (how GM food policy is carried out) takes place to a large extent at the Member State level. Implementation and evaluation (what effect GM food policy has) are important topics that are not the focus of this study.

${ }^{93}$ As this chapter goes on to explain, I also draw on historical institutionalism (for example Hall 1986, Thelen 2004), which within the list presented could be categorized as institutionalism, and on the argumentative approach (Hajer 1995), which could be classified as a post-positivist 


\section{Comparative historical analysis}

The second theoretical approach I use is comparative historical analysis. ${ }^{94}$ It relates to my research in that it offers tools and theoretical approaches to devise a comparative investigation of factors explaining different policy outcomes. Comparative historical analysis has a tradition of addressing macro-social or "big questions", as well as a tendency to "focus on comprehensive structures and large-scale processes that provide powerful clues to the patterning of social life" (Mahoney/Rueschemeyer 2003b: 7).

Comparative historical analysis can be characterized as "a research approach rather than a single overarching theory" (Skocpol 2003: 419). It is a family of theories and methods that analyze macro-social phenomena, including public policy outcomes, through the comparative and historical study of institutions, which are broadly defined to include "both formal organizations and informal rules and procedures that structure conduct" (Thelen/Steinmo 1992: 2). ${ }^{96}$ My research question - why is there a transatlantic rift in GM food policy? - is precisely this type of broad, comparative, outcome-oriented question, and it embraces this informal, loose meaning of institutions. Moreover, comparative historical analysis advocates the type of inductive framework-building that I engage in.

Comparative historical analysis has its roots in a long tradition of social thought going back several centuries. For example, nineteenth century founders of social science Alexis de Tocqueville and Karl Marx, and early twentieth century scholars such as Max Weber wrote about society from a comparative and historical perspective.

approach. In this study, I choose to discuss historical institutionalism under comparative historical analysis since I would argue that historical institutionalism, the strand of institutionalism I work with, fits better into comparative historical analysis, which has clarified and strengthened its research agenda during the past decade. As for Hajer's argumentative approach, it is a cross between policy process theory and science and technology studies, but clearly builds on the constructivist assumption found in STS.

\footnotetext{
${ }^{94}$ For an overview of comparative historical analysis, see Mahoney/Rueschemeyer 2003a.

95 Macro-social research questions or "big questions" address broad, systemic issues and phenomena, taking into account their social, political, institutional and historical context.

96 Historical institutionalist Peter Hall defines institutions as "the formal rules, compliance procedures, and standard operating practices that structure the relationship between individuals in various units of the polity and economy" (Hall 1986: 19).
} 
Researchers that view themselves as comparative historical analysts today are also bound together by their rejection of behavioralism, a US-developed research tradition that dominated the social sciences during the 1950s and 1960s. While social thought had focused on politics through the study of institutions and history, behavioralism was characterized by a focus on the importance of individual behavior. In terms of methodology, much like policy analysis in the 1950s and 1960s, behavioralism emphasized empirical techniques and privileged the search for universal and testable hypotheses through deduction.

In the late 1960s and 1970s, research approaches that can today be classified as comparative historical analysis once again began to take root, this time as a counter-movement to behavioralism. Specifically, researchers working within a comparative historical analysis tradition criticized the assumption that individual political behavior reveals preferences and that individual preferences can be aggregated into collective phenomena (Immergut 1998: 7). Instead, these researchers newly emphasized the importance of studying institutions in their historical context in order to explain broad social phenomena.

As mentioned above, comparative historical analysis today focuses on "first-order questions", or "big questions", that attract and fascinate people inside and outside of academic circles alike (Skocpol 2003: 409). These first-order questions involve topics of great social magnitude such as war and peace, revolutions, institutional change, social movements, and important public policy outcomes. Like policy process theory, comparative historical analysis is a positivist approach and is open to a plurality of theories and methods. According to Mahoney and Rueschemeyer, the three main elements characterizing comparative historical analysis are "causal analysis, an emphasis on processes over time, and the use of systematic and contextualized comparison" (Mahoney/Rueschemeyer 2003b: 6).

From within the field of comparative historical analysis, I use historical institutionalism (Hall 1986, Thelen 2004). As will be explained in more detail below, historical institutionalism is used in this dissertation to discuss the importance of policy in the area of recombinant DNA (rDNA) in the 1970s and 1980s to understand current GM food policies. 


\section{Science and technology studies}

The third body of theory that I draw upon is an area of studies called "science and technology studies", "science, technology and society", or "science studies" (STS or S\&TS) $)^{97}$. This field of scholarship's primary interest lies in understanding science and technology within their social contexts. It is concerned with analyzing issues relevant to science, technology and society, often controversies, through a constructivist lens in order to be able to raise questions about more positivist ways of understanding their relationship with society. As formulated by Jasanoff, one of the field's foremost representatives, its "foundational concern" is "the investigation of knowledge societies in all their complexity" (Jasanoff 2004: 2).

This study makes use of science and technology studies as a body of theories that makes it possible to explore more deeply the importance of cognitive elements in science and technology policy-making. Policy process theory and comparative historical analysis acknowledge the importance of beliefs and perceptions, but STS, through its constructivist lens, is able to push further in that direction. My work is essentially positivist, explanatory, and oriented towards a search for causality. However, my analysis is also very sensitive to the ways in which GM foods and related policy issues are constructed by individual actors in the US and the EU. In addition, empirically speaking, STS is highly valuable to my research in that it deals specifically with issues within the realm of science and technology. While policy process theory treats GM food as a policy area like any other, STS deals with the specificities of science and technology policy and politics. STS has yielded a series of interesting works on biotechnology policy, and on GM foods specifically, which I use as sources of information and inspiration throughout my study.

The study of science as a social phenomenon goes back to the rise of industrialization during the 19th century. At this time, sociologists such as Auguste Comte and Emile Durkheim held a traditional view of science and technology, dominant in Western industrialized societies to this day, as being objective, independent and neutral forms of knowledge used for the betterment of

\footnotetext{
${ }^{97}$ In their Handbook of Science and Technology Studies, Jasanoff et al. (1995) give an overview of the wide terrain covered by STS. Sismondo (2004) offers a useful introduction to STS.
} 
society. In this understanding, scientists enjoy high levels of authority and are viewed as apolitical and uncontroversial experts.

As early as the $16^{\text {th }}$ and $17^{\text {th }}$ century, Francis Bacon had suggested that human beings cannot possess objective pictures of the truth in their minds. $19^{\text {th }}$ century thinkers on the nature of science include Karl Marx, John Desmond Bernal and Max Weber, who viewed scientific "truths" as expressions of class interests. In the 1920s and 1930s, scholars such as Ludwik Fleck wrote about the link between science and society, making the assumption that knowledge is linked to cognitive beliefs.

In the 1940s, 50s and 60s, against the backdrop of the rise and fall of totalitarianism, the aftermath of World War II and the first decades of the Cold War, attention turned to the normative question of how scientific inquiry can operate uncontaminated by politics. Both Merton (1973 [1942]) and Polanyi (1962) viewed science in its ideal form as existing in a community of its own, separate from and untouched by society. While Merton became famous for his concept of the "ethos of science" describing a series of principles for the conduct of science, Polanyi developed the notion of a "republic of science", a community of scientists working according to economic principles and resembling a body politic.

STS as a field of scholarship developed in the 1970s as a reaction to these traditional views of science and technology, and drew on earlier work done in the history, sociology and philosophy of science. The nascent field of STS has gained in importance and recognition in the light of current events. A series of important technological advances, especially nuclear technology and genetic engineering, and increasing private and public sector expenditure for science and technology led not only to advances and successes, but also to failures, controversies, and to an increasingly critical and questioning public. These developments legitimized STS's research agenda by pointing towards the fact that science and technology could no longer be contemplated out of context.

One of the subareas that STS deals with is science and technology policy. Traditionally, the role of science in policy-making was and still is understood as furnishing policy-makers with scientifically accurate information and in 
“speaking truth to power" (Price 1965, Wildavsky $1987[1979]^{98}$ ). Following this logic, scientific knowledge feeds into policy, and science and technology policy is taken for granted as having been informed by the best available scientific and expert information. The underlying perception is that governments basing their decisions on this type of ideal process can achieve regulatory safety and be fully accountable to the public (Webster 1991). In the 1970s, at about the same time that policy analysts began to question the supremacy of rational cost-benefit analysis, STS scholars interested in science and technology policy began questioning the assumption that science policy-making is a linear process of scientific truths being fed into politics, with science policy as an output. Instead, assumes that science policy is the result of complex and non-linear interactions among science, politics and society.

STS pursues its interest in understanding these complex relationships through an agenda of raising questions concerning their perceived meanings and interactions. STS challenges the idea that science is neutral and objective whereas society is not, and questions the concept that science, technology and society are divided by clear boundaries. As will be described in detail below, from within the wide field of STS and the concepts and ideas leading up to it, I turn to scholars such as Fleck, Kuhn, Levidow, and Jasanoff to help me explain the transatlantic rift in GM food policy.

\subsection{Postulates}

\section{Causality}

The theoretical approaches I choose point toward two fundamental postulates. First, I posit that a workable and rewarding way to explain public policies is to address them as research puzzles ("why-questions"), and to explain them by searching for causal explanations. Policy process theory and comparative historical analysis both posit causal links between social outcomes (e.g. policy) and their explanation(s), in other words they see certain variables and variable

${ }^{98}$ Wildavsky shares the basic view that policy analysis should and can furnish policy-makers ("power") with accurate and useful information ("truth"). However, his is a nuanced account that recognizes that the "truth [that] analysts claim today is not always the same truth they will claim tomorrow" and that, therefore, the "truth" that policy analysis speaks to "power" is not immutable (Wildavsky 1979: 402). 
combinations as leading to certain outcomes. Policy process theorists often take causality for granted and do not discuss this postulate in detail. An exception is Scharpf, a policy process theorist representing a game theoretical/rational choice approach, who makes the assumption of causality explicit:

"we must go beyond descriptive case studies and narrative explanations [...]: We need to have hypotheses that specify a causal model showing why and how a given constellation of factors could bring about the effect in question [...]" (Scharpf 1997: 28).

Comparative historical analysts are relatively explicit about causality being one of their unifying and guiding elements: "comparative historical inquiry is fundamentally concerned with the explanation and identification of causal configurations that produce major outcomes of interest" (Mahoney/Rueschemeyer 2003b: 11). Furthermore, "most comparative historical analysts believe that it is difficult to conduct any kind of social science analysis without at least implicitly making causal claims" Mahoney/Rueschemeyer 2003b: 23).

In contrast, while STS is conscious of causality, it disagrees with variablebased explanatory models, maintaining that causality and directionality are not worth looking for since they posit artificial and reductionist views of the interactions among science, society and politics. Instead, STS has developed frameworks of its own to describe and explain complex phenomena resulting from causal interactions. One of these is the concept of co-production (Jasanoff 2004) or co-evolution (Nowotny et al. 2001). STS assumes that science, politics, polity, the market, etc. are engaged in complex and multidirectional causal exchanges and interrelationships, and that these interactions mutually condition and determine one another. Therefore, no linear causality is posited, and no directionality is allowed: "the production of order in nature and society has to be discussed in an idiom that does not, even accidentally and without intent, give primacy to either" (Jasanoff 2004: 20).

One aspect of causality that is especially important to this dissertation is the supposition that explanations of complex phenomena such as policy outcomes 
are context-sensitive and multifaceted. ${ }^{99}$ All of the theoretical approaches I make use of are based on this assumption. One of policy process theory's central features is that it often takes into consideration and assembles a complex set of elements such as beliefs, institutional arrangements, actors' resources, and context. Policy process theory models such as Kingdon's multiple streams (1984) or Sabatier and Jenkins-Smith's Advocacy Coalition Framework (1993, 1999) rely on the interaction of a multitude of explanatory elements to be viewed within a larger societal context. In Kingdon's multiple streams model, three policy streams - "problems", "policy primeval soup", and "political stream" occasionally come together to create "policy windows" during which policy solutions are shaped. These streams contain a multitude of interacting factors and actors such as "problem definition" (problems stream), "policy communities" or specialists in a given policy area (policy stream), "organized political forces" and "the national mood" (political stream). The Advocacy Coalition Framework, discussed in more detail below, uses concepts such as "beliefs", "advocacy coalitions", and "external events" to explain policy outputs. In both of these examples, the interaction of multiple elements is crucial to explaining policy outcomes.

Comparative historical analysis declares the use of "contextualized" comparison to be one of its main tenets (Mahoney/Rueschemeyer 2003b: 6). Historical institutionalism, one important theoretical approach within comparative historical analysis, stresses that its "emphasis on institutions [...] does not replace attention to other variables - the players, their interests and strategies, and the distribution of power among them. On the contrary, it puts these factors in context, showing how they are related to one another [...]" (Thelen/Steinmo 1992: 12). Indeed, within this approach, causality is viewed as being contextual (Immergut 1998: 19) and analysis focuses on "illuminating how

\footnotetext{
${ }^{99}$ One of the ways in which multivariate qualitative analysis and the problem of "conjectural causation" (causation not proven or based on evidence) has been approached is through qualitative comparative analysis (QCA), an analytic technique developed by Ragin $(1987,2000)$ that uses Boolean algebra to study macro-social phenomena in a comparative manner, thus bringing together aspects of qualitative and quantitative analysis. Typically, studies using qualitative comparative analysis conduct a systematic comparison of dichotomously categorized data across more than two or three cases, investigating under which conditions a certain social or political outcome is realized. For example, Varone et al. (forthcoming) apply the method of qualitative comparative analysis to the policy field of assisted reproductive technology.
} 
different variables are linked" (Thelen/Steinmo 1992: 13). Ideally, a "balance between necessary complexity and desirable parsimony" is struck (ibid.).

Although STS does not proceed by seeking causal explanations to research, "why-puzzles", it shares with policy process theory and comparative historical analysis the assumption that controversial issues like the regulation of GM food must be understood within a complex social context composed of multiple actors and issues. For example, actor-network theory (Callon 1986, Latour 1987), a prominent theory within STS, suggests that the actors involved in a scientific discovery or technological advance can be individuals, organizations, or objects (e.g. the technological discovery itself, or an element which makes it possible). These actors create networks surrounding scientific advances or technological developments. Jasanoff's framework of co-production, referred to above, is also a case in point. In describing her framework, she emphasizes that "What happens in science and technology today is interwoven with issues of meaning, values and power in ways that demand sustained critical inquiry" (Jasanoff 2004: 25). This standpoint would undoubtedly be shared by policy process theorists and comparative historical analysts, and underlines the fact that STS, as well as the other approaches used, is a discipline based heavily on interactions and multifaceted analysis.

\section{Beliefs matter}

Second, I postulate that the beliefs and perceptions of individual and collective actors play an important role in explaining policy outcomes. This assumption is contained in all of the theoretical approaches I draw on. In postulating that beliefs matter, I clearly distance myself from theories that posit that individual actors act rationally, according to specific preferences, in order to achieve certain goals and maximize their benefits (e.g. rational choice institutionalism). It is my conviction that individual and collective ways of describing, conceptualizing and placing GM food on the political agenda are crucial for understanding differences in policy outcomes.

Some theories within policy process theory emphasize the importance of beliefs as a reaction to the tradition of policy analysis, which relies on the concept of rationality. Many policy process theorists disagree with the view that policy- 
making is a purely rational process by emphasizing that "cognitive limits on individuals make analysis [in the traditional rational cost-benefit sense] difficult" and that "politics governs nearly every political decision" (White 1994: 860). Many policy process theories such as Sabatier and Jenkins-Smith's Advocacy Coalition Framework (Sabatier and Jenkins-Smith 1993, 1999) and Jobert and Muller's concept of the "referential" (référentiel) (Jobert / Muller 1987) grant beliefs a central position.

Similarly, comparative historical analysis "typically [gives] subjective beliefs a more central place, together with 'objectively' changing contexts [than rational choice approaches] (Mahoney/Rueschemeyer 2003b: 21). Comparative historical analyst and historical institutionalist Hall, for example, develops the belief-based concept of "policy paradigms". Historical institutionalists in general emphasize "socially and politically constructed preferences" (Thelen/Steinmo 1992: 8).

As a constructivist theoretical approach, STS is based on the premise that socially constructed beliefs are crucial for understanding how controversies around science and technology policy arise. STS scholars see science and technology as being defined by social norms. The basis of an STS analysis is a constructivist understanding of social phenomena, which, in opposition to realist perspectives, states that knowledge is subjective and that it develops as a subjective construction of ideas and concepts. For example, in his comparative analysis of the regulation of genetic engineering, Gottweis, a scholar situated between policy process theory and STS, argues that "actors and institutions must always be analyzed in close association with the discourses in which they are constituted and with the policy stories that define the logic, the actors, and the institutions that matter in a policy field" (Gottweis 1998: 3). He rightly emphasizes that "comparative political studies [...] have remained relatively untouched by this new approach and continue to look at politics through a lens narrowed by realist epistemology and positivist methodology" (ibid.). 


\subsection{Method}

\section{Developing a "medium-range" framework}

In order to explain GM food policy differences, I seek to create an analytical framework which will form a basis for considering empirical data on GM food policy processes in the US and the EU. The framework I develop may help researchers investigate other controversial policy areas, but it is designed specifically for the case of GM food policy in the US and the EU. It does not aim or claim to be universally applicable to the public policy process.

This limited focus is widespread in comparative historical analysis and policy process theory. Research within these traditions agree that in order to explain broad social and political phenomena, a search for universally applicable principles and rules (as conducted in many areas of social science) is not necessarily desirable (Mahoney/Rueschemeyer 2003b: 8). Indeed, in pursuing these types of research questions, comparative historical analysts are not concerned with "grand theorizing" (Thelen/Steinmo 1992: 5), but rather with finding "bits of sometimes true knowledge" (Rueschemeyer 2003: 328). The idea is that an in-depth understanding of individual case studies will yield specific knowledge that may lead to generalizations, but not to universal rules. Comparative historical analysis and policy process theory therefore agree that answers to research questions of this type can and perhaps should be very case and data-specific. Moreover, Scharpf suggests that "lawlike generalizations" may be desirable, but that they are "nearly impossible" to achieve in "interactionoriented policy research" (Scharpf 1997: 19).

In order to conduct in-depth case study research, policy process theory and comparative historical analysis suggest using "focused theoretical frameworks" or "meta-theories", which often "are not directly testable but seek to establish the most fruitful intellectual framework for the investigation" (Rueschemeyer 2003: 329). Such frameworks aim to explain the specific research question at hand. Rueschemeyer describes such frameworks as "focused theoretical frameworks for the study of particular substantive problem areas [...]", which lead to "subjectand problem-specific meta-theories" (2003: 329). Hall calls this type of theoretical framework "middle range" and describes it as focusing "on intermediate variables in order to integrate an understanding of general patterns 
of political history with an explanation of the contingent nature of political and economic development" (Hall 2003: 27-8).

Out of what elements and how is a medium-range analytical framework built? Policy process theory and comparative historical analysis agree that it should be based on theoretical and methodological pluralism. Scharpf writes that complete explanations "can only be modular constructs, combining and linking several theoretical "modules" (Scharpf 1997: 30). As put by Mahoney and Rueschemeyer, "comparative historical analysts need not embrace any single approach to causal analysis" (2003b: 12). Instead, a medium-range theory should use "methodological and theoretical eclecticism" (Skocpol 2003: 411), and is "thus splendidly open to synergy and innovation" (Skocpol 2003: 420). I follow these bits of advice by adopting theoretical heterogeneity in order to strive for a comprehensive and multi-approach explanation of why GM food policies are different in the US and the EU.

Equally important for the process of creating a medium-range framework is the dialogue-like process by which it is developed. In writing this dissertation, I started out with certain theories and assumptions, from which I extracted concepts and guiding propositions to approach the empirical part of my project. In the process of my research, I have constantly gone back and forth between my empirical data and my analytical framework, until the framework "made sense" and offered a sound approach to explaining GM food policy differences. While virtually all of social science requires working in this way, it is seldom explicitly spoken of as a necessary and useful part of the research process. It is at most described as having a "corrective" function. Comparative historical analysis, however, makes specific reference to this type of research process, describing it as "a dialogue between theory and evidence of an intensity that is rare in quantitative social science" (Mahoney/Rueschemeyer 2003b: 13). As foreseen by comparative historical analysis, I have been able to "comfortably move back and forth between theory and history [in my case theory and empirical findings] in many iterations of analysis" (ibid.).

In accordance with the goal of developing a medium-range framework, I formulate research propositions instead of hypotheses. While hypotheses are statements derived exclusively from theory for the purpose of testing whether or 
not specific relationships exist between certain variables, propositions can be formulated taking into account preliminary empirical findings. Moreover, propositions do not necessarily suggest precise relationships between variables, but can be of a more open nature.

\section{Focused and systematic comparison of two cases}

In order to explain US and EU policy differences, I conduct a focused and systematic public policy comparison. While comparison as a method is an obvious choice considering my research question, it is worth underlining the research benefits of comparison in general terms. In essence, comparison is a procedure that enables us to develop theory and generate hypotheses about society. As underlined by Mackie and Marsh (1995: 175-6), one of the main reasons for comparison is "to generate, test, and subsequently reformulate theories [...] about the relationship between political phenomena." STS scholar Jasanoff agrees: "Comparative policy studies offer a promising vehicle for clarifying how knowledge interacts with politics and culture [...]." (Jasanoff 1991: 62). In her recent work, she even states that "[c]omparative studies of science and technology policy should be seen today as a powerful means of developing social theory" (Jasanoff 2005: 12).

This dissertation can be characterized as a "focused comparison" (Hague et al. 1998) of two in-depth qualitative case studies or "process studies" (Peters 1998). This type of comparison is common in policy process theory, comparative historical analysis, and science and technology studies alike. This approach puts as much emphasis on comparison as it does on the cases themselves. It pursues the goal of remaining "sensitive to the details of particular countries and policies while also forcing the intellectual discipline which inheres in the comparative enterprise" (Hague et al. 1998: 280). Therefore, I do not present my work as two separate, consecutive case studies. Rather, my comparison of GM food policy in the US and the EU is guided by comparable themes, issues and elements.

In comparing GM food policy in the EU and the US, I juxtapose two cases and must therefore consider "small-N" (small number of cases) research design issues. The trouble most frequently associated with this type of study is the danger that "extraneous variance", i.e. extra independent variables not targeted as 
objects of study, might interfere with the dependent variable (Peters 1998, Mackie/Marsh 1995). Przeworski and Teune (1970) and other comparativists such as Lijphart (1975) have argued that case selection should therefore follow either a "most similar systems design" or a "most different systems design". The most similar systems design strategy consists of selecting cases in which as many extra independent variables as possible are similar. By thus excluding other possible explanatory variables, this type of design ensures that the independent variables singled out for testing can constitute actual explanations. The opposite strategy, the "most different systems design", selects units for comparison that differ in many respects (Przeworski/Teune 1970, Peters 1998). The goal of this strategy is "to show a robust relationship by demonstrating its validity in a range of contrasting settings" (Hague et al. 1998: 281).

While the rules devised by Przeworski and Teune are well-suited for "large N" or "medium-N" research designs seeking generalization and universal principles, they are less useful for the focused comparison that I conduct. Indeed, to the question "How should countries be selected for a focused comparison?", Hague et al. reply that "[...] considerations of substance [...] should trump methodological factors. Accordingly, in much "small-N" research, countries are selected not as 'cases' but for their intrinsic interest" (Hague et al. 1998: 280, my emphasis).

In the case of GM food policy, it would be a mistake to bypass the “considerations of substance" underlined by Hague et al. In this sense, I suggest that a transatlantic comparison of GM food policy must compare EU and US regulations because, at the transatlantic level, agricultural biotechnology is regulated first and foremost by the US federal government and by the European Union. In the US, Congress and the federal government have the power to regulate the areas of agriculture and food safety. In the European Union, GM food and crop policy falls within the area of the internal market and is thus shaped at the EU level, by the European Commission, European Parliament, and Council of the $\mathrm{EU}^{100}$. By comparing GM food policy in the EU and the US, I thus compare what is appropriate to compare. "Intrinsic interest", a further criterion suggested by Hague, is equally present for my case study selection: the EU and

${ }^{100}$ The Council of the EU is composed of Member State representatives and therefore represents their interests. Member States are also significant for the implementation of EU-level policy. 
the US are the two main GM food regulators worldwide, and their differing policies have led to a major transatlantic trade clash within the WTO.

For these reasons, I maintain that a comparative study of the EU and the US is a valuable enterprise despite the inherent limitations resulting from its imperfect conformity with a most similar systems design. Since I am interested in explaining policy differences, my study roughly follows a most similar systems design. Potentially important explanatory variables that are similar in both the US and the EU include the level of industrial and technological development (high in both cases) $)^{101}$, the type of economy (both market economies), and centerperiphery structure (both are federal systems).

Regarding the center-periphery structure, to be sure, EU Member States are nation-states while US states are not; the US is one nation-state, whereas the EU is a union of nations-states. This systemic difference has been used to explain the differences between GM food policies. For example, Bernauer does this from a rational choice perspective. He dedicates a chapter of Genes, Trade and Regulation to what he calls "regulatory federalism", in which he "concentrates on whether political subunits within the federal system can, by unilaterally installing stricter or laxer regulation of agricultural biotechnology, push the stringency of system-wide regulation up or down" (Bernauer 2003: 102). ${ }^{102}$ Whether it is made from a rational choice perspective or not, I recognize the importance of this institutional argument, but choose not to treat federalism as a separate explanatory variable. Instead, I take it into account by discussing the role of EU Member States and US states as actors who influence policy outcomes through their activities are beliefs.

On a more general level, I do not focus on institutions and institutional arrangements to explain policy differences, but conceptualize them as the glue

${ }^{101}$ It should be noted, however, that the US is further developed than the EU in terms of biotechnology applications.

${ }^{102}$ Bernauer concludes that in the EU, "we observe a substantial 'ratcheting-up' effect, whereas such an effect is absent in the United States" (Bernauer 2003: 102). He constructs his argument on a series of rational choice-based assumptions. He supposes that if subunits (EU Member States or US states) pursued opposite policies, considerable economic damage would follow. He further suggests that in the case of regulatory disagreement, a harmonized solution based on strict regulation is the most desirable situation possible for all. 
that holds explanatory variables together. ${ }^{103}$ Like Ostrom, I understand institutions to be no more than the set of formal and informal rules that are used, so-called "rules-in-use" that depend on the shared beliefs of those actors that formulate them (Ostrom 1990). As Scharpf notes,

"[...] we must remain aware of the fact that although institutions constitute composite actors, create and constrain options, and shape perceptions and preferences, they cannot influence choices and outcomes in a deterministic sense. Institutionalized rules, even if they are completely effective, will rarely prescribe one and only one course of action. Instead, by proscribing some and permitting other actions, they will define repertoires of more or less acceptable courses of action that will leave considerable scope for the strategic and tactical choices of purposeful actors" (Scharpf 1997: 42).

In summary, I take into account institutions and institutional arrangements and the role they play as part of the analysis of actors and events within the field of GM food policy.

A further methodological problem is that the two case studies I select are not independent from each other. As the chronologies of the US and the EU cases in Chapter 2 show, the US and the EU often react to each other's policies and actions. International actors such as the WTO and multinational biotechnology companies, neither of which can be classified as belonging completely to either case, exemplify the interdependence of the two selected case studies selected. It is therefore plausible to consider each case study as a factor influencing policy outcomes in the other. The difficulty that case studies may not constitute independent observations is known as "Galton's problem", and is common in social science studies conducted across countries (see, for example, Przeworski/Teune 1970: 52-53, Gerring 2001: 178-181). Some scholars study precisely this phenomenon, instead of treating it solely as a methodological obstacle. For example, the policy diffusion approach specifically investigates in what way policy choices are interdependent and influence one another (Berry/Berry 1999, Braun/Gilardi 2005). For the in-depth case study research as

${ }^{103}$ This assumption is connected with the postulate discussed above that beliefs matter. My work is guided by the supposition that institutions are important primarily through actors and actors' beliefs. 
undertaken in this dissertation, Galton's problem cannot be solved. The only possible strategy is to be aware of it in order to gauge its possible effects while analyzing empirical evidence.

\section{Data sources}

The methods of data collection and analysis used in this dissertation are qualitative. This is in accordance with its research goal, assumptions and theoretical approach, as qualitative methods tend to aim at understanding processes and explaining outcomes. Qualitative methods "capture meaning, process and context" (Devine 1995: 138) and can thus get as close as necessary to the object of study (Flick et al. 2000: 17). ${ }^{104}$ Within this process of "getting close", I find the description of the "qualitative researcher as bricoleur and quiltmaker" to be very fitting (Denzin/Lincoln 2000: 4). The topic of GM food policy lends itself to qualitative analysis particularly well. Indeed, the highly political nature of this policy area, as well as the ethical questions, emotions and controversy it has generated over the past decade beckon for qualitative inquiry (Schubert 1991, House/Shull 1991).

From within the wide field of possible qualitative methods, I use semidirective interviews (following the methods described, for example by Meuser/Nagel 1991 or Weiss 1994) and documentary analysis. Thus, my first source of data are thirty-five semi-directive interviews conducted with US and EU policy-makers, stakeholder representatives (e.g. environmental NGOs, consumer associations, industry) and academics active and/or knowledgeable in the area of GM food policy. ${ }^{105}$ I selected my interview partners to represent a broad range of viewpoints and positions within the GM food debate. The interviews lasted from one to two hours each. Working with audio recordings and notes, I then summarized the content of all the interviews in order to gain a complete overview of the themes addressed. The data gained in this manner was crucial in terms of ordering and understanding the information to be found in primary documents and secondary literature. Throughout this dissertation, I have

${ }^{104}$ In contrast, in quantitative analyses, research usually tries to predict outcomes and test hypotheses; findings are precise and numerical (Merriam 1998: 9).

105 A complete list of interviewees' names and affiliations is provided at the end of this dissertation. 
made use of direct quotations from my interviews when interviewees were in agreement. Second, I analyze a vast selection of primary documents including legislation, regulations, opinions, recommendations, speeches, interest group position papers, and many other sources. Third, I make use of the abundant secondary literature available on the GM food debate in general, and the growing literature on GM food policy in particular.

\subsection{Analytical framework}

In order to compare GM food policies in the EU and the US and explain their differences, I extract three explanatory variables from individual theories within the fields of policy process theory, comparative historical analysis, and science and technology studies: "preceding policies", "paradigms", and "actors and actor coalitions". Each variable is not necessarily derived from only one family of theories, and not every family of theories is used to investigate each variable. Two out of the three variables are based on theories from more than one theoretical approach (see Table 11). Based on these three variables, I formulate three propositions about why GM food policy is relatively permissive in the United States and relatively restrictive in the European Union.

\section{Table 11: Theoretical basis for explanatory variables}

\begin{tabular}{|l|l|}
\hline \multicolumn{1}{|c|}{ Explanatory variables } & \multicolumn{1}{c|}{ Theoretical approaches } \\
\hline "preceding policies" & comparative historical analysis \\
\hline "paradigms" & $\begin{array}{l}\text { policy process theory } \\
\text { science and technology studies }\end{array}$ \\
\hline "actors and actor coalitions" & $\begin{array}{l}\text { policy process theory } \\
\text { science and technology studies }\end{array}$ \\
\hline
\end{tabular}

\section{Explanatory variable 1: preceding policies}

This dissertation's first explanatory variable is based on the notion that history is one of the elements that can help explain different policy outcomes. This explanatory variable is named "preceding policies" for short, and is 
understood in this dissertation as earlier policy or policies relevant for and/or leading to a current policy area.

The policy area relevant for and leading to GM food policy for the purposes of this explanatory variable is recombinant DNA research policy. Recombinant DNA research - and not agriculture or the environment - is selected as the "preceding policy area" to be investigated for two reasons. First, rDNA research forms the scientific and technological basis for agricultural biotechnology. Second, the rDNA technology underlying GM foods is what makes GM foods and crops controversial and therefore rewarding to study as a policy area.

This concept of preceding policy draws on historical institutionalism, a theory that can be categorized as belonging to the field of comparative historical analysis. Important contributions to and discussions of the field of historical institutionalism include Immergut 1992, Immergut 1998, Hall 1986, Hall 1993, Hall/Taylor 1996, Mahoney 2001, Peters 1999, Pierson 1994, Pierson 2004, Rose/Davies 1994, Skocpol 1995, Steinmo/Thelen/Longstreth 1992, and Thelen 2004. Hall's work is of particular relevance to my project because it uses the historical institutionalism framework to explain public policy outcomes across nations (Hall 1986). Thelen and Steinmo comment that Hall is "the most explicit on the question of how institutions fit into the analysis of policy making and politics within historical institutionalism" (Thelen/Steinmo 1992: 2).

Historical institutionalism's first and most basic premise is that "history matters". Its interests include the genesis, change and impact of organizations, institutions and public policies (Skocpol 1995). Historical institutionalists often strive to explain institutional variance across nations or institutional change over time. They find that the "problems (and solutions) that emerged historically are what lie behind some of the striking contemporary national differences in [...] regimes [...]" (Thelen 2004: 20). Historical institutionalism is based on the idea that " $[. .$.$] early developments get deeply embedded in a particular environment,$ altering the resources, incentive structures, and hence behaviors of social actors [...]" (Pierson 2004: 64). Applied to public policy, this means that "the policy choices made [...] when a policy is initiated will have continuing and largely determinate influence over the policy far into the future" (Peters 1999: 63). 
A second central assertion found in the work of many historical institutionalists is that institutional and policy outcomes can be explained through the concepts of "path dependence", "positive feedback", "lock-in effects", and "critical junctures". 106 "Path dependence" refers to "self-reinforcing processes" in which initial institutional choices are maintained, repeated and perpetuated through "positive feedbacks" in order to avoid the costs of reversal (Mahoney 2001, Pierson 1994, Pierson 2004). This concept of "path dependence" may result in a tendency for policies to remain unchanged or to change only incrementally for long periods of time. "Lock-in effects" refer to the idea that institutions or policies remain locked on one trajectory as a result. "Critical junctures" are the historical points in time when institutional choices are made and are "the origins of cross-national variation in important institutional arrangements" (Thelen 2004: 27).

Finally, historical institutionalists' analyses emphasize actors, coalitions, power and resources. Thelen writes that her "characterization of institutional genesis [...] emphasizes a strong power-distributional component [and that it] focuses heavily on political coalitions and political conflicts" (Thelen 2004: 32). Skocpol agrees that historical institutionalism is about studying political processes and outcomes, and therefore about actors agreeing and disagreeing (Skocpol 1995).

Drawing on these main assumptions of historical institutionalism, I conceptualize previous relevant policy as an explanatory variable. I suggest that "history matters" to explain US and EU GM food policies. The content and development of policies in the area of rDNA research are part of the explanation for why GM food policies are more or less restrictive. My first proposition reads as follows:

106 A similar concept, found within policy process theory, is "punctuated equilibrium theory" which sees policy-making as being characterized by long periods of near stasis and only incremental change (the equilibrium), and by brief periods of major policy change (the punctuation of the equilibrium) (Baumgartner/Jones 1993). 


\section{Proposition 1: preceding policies matter}

The US's relatively permissive GM food policy builds on and can be explained by relatively permissive preceding policy in the field of rDNA research.

The EU's relatively restrictive GM food policy builds on and can be explained by relatively restrictive preceding policy in the field of rDNA research.

\section{Explanatory variable 2: paradigms}

The second explanatory variable is based on the assumption that policymakers' collective ideas and beliefs influence policy outcomes. I call it "paradigms" and define a paradigm as an overarching framework of fundamental beliefs about a policy area, which often reaches into other policy domains. The theoretical foundation for this concept of "paradigm" is inspired by all three theoretical approaches used - policy process theory, comparative historical analysis, and science and technology studies.

In this dissertation, paradigms are explanatory. They are not understood as part of GM food policy, the dependent variable to be explained. Unlike policy guiding principles contained in policy documents, paradigms are often not explicit or apparent. They influence policy at a deeper and more allencompassing level than, for example, the "product" versus "process" distinction explained in Chapter 3. What is more, paradigms often reach beyond a specific policy field and influence others. While the product versus process distinction is part of the policy differences to be explained, the paradigms I discuss in this dissertation form an independent variable.

The notion that cognitive and normative elements play an important role in establishing what is considered to be true and what is not can be traced back to Ludwik Fleck, a historian, philosopher of science and a physician. In Genesis and Development of a Scientific Fact, Fleck conducts in-depth case studies on how so-called scientific facts come to be viewed as such (Fleck 1979 [1935]). In his view, science and scientists are organized into "thought collectives" or communities of "persons mutually exchanging ideas or maintaining intellectual 
interaction" (Fleck 1979 [1935]: 39). A "thought collective" shares a "thought style", which Fleck defines as "directed perception, with corresponding mental and objective assimilation of what has been perceived", that determines "what can be thought in no other way" (Fleck 1979 [1935]: 99). Fleck thus introduces the idea that certain groups of people perceive designated areas of knowledge in particular ways.

Fleck's thought style concept has much in common with what physicist and historian of science Thomas Kuhn has termed "paradigm". Kuhn introduced the notion of "paradigm" in The Structure of Scientific Revolutions (1996 [1962]). He argues that science is not a gradual, cumulative acquisition of knowledge, but rather a succession of peaceful periods interrupted by "scientific revolutions" that result in one conceptual world being overturned and replaced by another. These conceptual worlds are what Kuhn refers to as "paradigms". He describes a paradigm as an "implicit body of intertwined theoretical and methodological belief that permits selection, evaluation, and criticism" (Kuhn 1996 [1962]: 16-17). For Kuhn, a paradigm is an overall framework that enables an understanding of scientific phenomena and guides scientific research.

Science, technology and society studies scholars such as Jamison (1987, 1991), and Jasanoff $(1995,2000,2005)$ have applied concepts similar to "paradigm" to policy-making, showing that science and technology policies correspond to certain national styles of regulations, and that they are constructions based on distinct ways of framing and on individual sets of ideas and beliefs. Special domains of inquiry addressed by these authors are the role of language, expertise, science, and differing understandings of risk and acceptable evidence - all areas that are highly relevant to the case of GM food policy.

Similar concepts can be found within the fields of comparative historical analysis and policy process theory. As a review article on policy process theory literature, Surel notes that there "has been an increasingly important shift in the analysis of public policy [...] with the development of an approach which emphasizes the influence of ideas, general precepts and representations" (Surel 2000: 495). For example, historical institutionalist Hall, a representative of the field of comparative historical analysis, uses the concept of "policy paradigm", making direct reference to Kuhn and adopting his vocabulary. In his paper on 
macroeconomic policy-making in Britain, Hall defines a "policy paradigm" as follows:

"[...] policymakers customarily work within a framework of ideas and standards that specifies not only the goals of policy and the kind of instruments that can be used to attain them, but also the very nature of the problems they are meant to be addressing. [...] This framework is embedded in the very terminology through which policymakers communicate about their work, and it is influential precisely because so much of it is taken for granted and unamenable to scrutiny as a whole. I am going to call this interpretative framework a policy paradigm" (1993: 279).

In this definition, Hall mentions that policy paradigms contain the "very nature of the problems addressed" and thereby implies that issues are seen in a certain light, that they are connected with certain ideas and perceptions.

An example of the use of the concept of "paradigm" in policy process theory is found in the work of Jobert and Muller. In their book L'État en action (1987), they coin the concept of "referential" ("reférentiel"107, containing, or constituting a reference) as part of their endeavor to develop a theory of "the social genesis of policies". Referentials present "dominant images" of a society ("global referential") or of a specific policy ("sector-related referential"). The two types of referential are inextricably linked in that a global referential creates the context for sector-related referentials. The existence of these referentials leads to a series of "norms [...]: laws, ordinances, procedures, etc." (Jobert/Muller 1987: $70)$.

Similarly, in their "framework for reflection on intractable policy controversies", Schön and Rein introduce the concept of "frames", which they define as "underlying structures of belief, perception, and appreciation" (Schön/Rein 1994: 24). Accordingly, they see policy controversies "as disputes in which the contending parties hold conflicting frames" which "determine what counts as a fact and what arguments are taken to be relevant and compelling" (ibid.). Significantly, "the frames that shape policy positions and underlie

${ }^{107}$ Translations from Jobert/Muller 1987 are by the author. 
controversy are usually tacit, which means that they are exempt from conscious attention and reasoning" (ibid.).

A further use of the notion of ideas and cognitive elements in public policy studies is found in Sabatier and Jenkins-Smith's Advocacy Coalition Framework (ACF) (Sabatier/Jenkins-Smith 1993, 1999, Sabatier 1998). The ACF contends that the policy process consists of competition among "advocacy coalitions" or groups rallying around particular policy preferences within specific "policy subsystems", defined as "the group of people and/or organizations interacting regularly over periods of time of a decade or more to influence policy formulation and implementation within a given policy area/domain" (Sabatier/Jenkins-Smith 1999: 135).

The ACF supposes that "preexisting beliefs [of individuals within advocacy coalitions] constitute a lens through which [individual and collective] actors perceive the world" and that "actors in different coalitions will perceive the world through different lenses and thus will often interpret a given piece of evidence in different ways" (1999: 131). Sabatier and Jenkins-Smith suggest that advocacy coalitions are held together by a "belief system" consisting of three types of beliefs: a) "deep core" beliefs are "basic ontological and normative beliefs"; b) "policy core" beliefs "represent a coalition's [...] normative commitments and causal perceptions across an entire policy domain or subsystem"; c) beliefs regarding "secondary aspects" are "a large set of narrower [...] beliefs", for example, concerning the seriousness of a policy problem, specific desirable regulatory measures, budgetary allocations etc. (1999: 121 et seq.). Deep core beliefs are stronger and more resistant to change than policy core beliefs, which in turn override beliefs concerning secondary aspects.

In order to apply the concept of paradigms to explaining GM food policy outcomes, Chapter 6 searches for and investigated the paradigms underlying GM food policy in the EU and the US. Accordingly, proposition 2 states the following: 


Proposition 2: paradigms matter
US and EU policies regarding GM food differ as to their level of
restrictiveness/permissiveness because they are guided by different underlying
paradigms.

\section{Explanatory variable 3: actors and actor coalitions}

The third and final explanatory variable suggests that US and EU actors and actor coalitions have achieved different levels of success in supporting and rejecting GM food, and that these differences have helped render policies more or less restrictive. My analysis of actors' success levels draws on two different approaches containing two conceptions of coalitions: Sabatier and JenkinsSmith's Advocacy Coalition Framework (ACF) offers the concept of "advocacy coalition", and Hajer's argumentative approach suggests the idea of a "discourse coalition". I choose these approaches because each contains a different important aspect of coalitions. While the ACF addresses the importance of common goals and coordinated activity, the argumentative approach emphasizes that successful coalitions are bound together by common language and discourse. ${ }^{108}$

The Advocacy Coalition Framework (Sabatier and Jenkins-Smith 1993, 1999, Sabatier 1998) portrays the policy process as a competition among two or more "advocacy coalitions", i.e. groups of actors supporting specific policy preferences within specific policy subsystems. Advocacy coalitions are held together by the system of beliefs described under the second explanatory variable (paradigms). ${ }^{109}$ For Sabatier and Jenkins-Smith, advocacy coalitions must

${ }^{108}$ I do not suggest that the Advocacy Coalition Framework does not also contain cognitive elements, and that the argumentative approach does not consider goals and coordinated activity. I simply select from each approach the concepts which are most convincing and useful for my analysis.

${ }^{109}$ For my discussion of coalitions, instead of using the Advocacy Coalition Framework's "belief system" concept, I favor Hajer's somewhat different notion of "story-line", which adds a more cognitive dimension to my assessment of the nature and success of actors and actor coalitions. In the ACF, beliefs are clearly defined and a function of rationally formulated interests and goals. In the argumentative approach, the causality is reversed: beliefs change and evolve through discourse and determine interests and goals. 
"engage in a non-trivial degree of coordinated activity over time" (Sabatier and Jenkins-Smith 1999: 120). They can include representatives of interest groups, regulatory agencies, legislative institutions, as well as researchers and journalists. Moreover, The ACF is built on the assumption that actors in advocacy coalitions share the same interests, that they are "instrumentally rational - that is, that they seek to use information and other resources to achieve their goals" (Sabatier and Jenkins-Smith 1999: 130). In the ACF, actors' interests and intentions can change as a result of "policy-oriented learning", defined as "relatively enduring alterations of thought or behavioral intentions that result from experience and/or new information and that are concerned with the attainment of policy objectives" (Sabatier/Jenkins-Smith 1999: 123).

The second approach used is Hajer's "argumentative approach", situated at the intersection of STS and policy process theory (Hajer 1995, see also Fischer/Forrester 1993) ${ }^{110}$. This approach supposes that issues are constructed through the "argumentation" of interest groups. Argumentation consists of different discourses, which in turn constitute different groups' interests, positions and cognitive beliefs. Interests can never be assumed as given since the rise of a new policy discourse can alter beliefs and interests, and therefore lead to policy change.

The argumentative approach introduces the concept of a "discourse coalition", a coalition based on common language and story-lines (Hajer 1995). "Discourse" is defined as

"a specific ensemble of ideas, concepts, and categorizations that it produced, reproduced, and transformed in a particular set of practices and through which meaning is given to physical and social realities" (Hajer 1995: 59-60).

"Story-lines" are "narratives on social reality through which elements from many different domains are combined, and which provide actors with a set of symbolic references that suggest common understanding" (Hajer 1995: 62). They create discourse coalitions by establishing causalities and ideals of social and moral order, by attributing blame and responsibility, and by determining

\footnotetext{
110 The argumentative approach's constructivist assumptions point towards an STS approach; its focus on explaining public policy and its outcomes is typical of policy process theory.
} 
what type of behavior is necessary in the face of a specific problem (Hajer 1995: 65). Three elements determine which coalition achieves the most influence on policy in a given moment: "credibility", which makes actors believe in the implications of a certain story-line, "acceptability", i.e. attractiveness and necessity attached to a particular discourse, and "trust", which refers to the level of confidence that story-lines can secure. When a high level of these elements is achieved, a certain story-line can reach "discursive dominance or hegemony". This in turn can influence policy outcomes and lead to "discourse institutionalization", i.e. translation into institutional arrangements and policies. ${ }^{111}$

The following table summarizes the differences between advocacy coalitions and discourse coalitions in terms of their driving forces and methods, conscious or unconscious, to achieve their policy goals.

Table 12: Differences between advocacy and discourse coalitions

\begin{tabular}{|c|c|c|}
\hline & Advocacy coalitions & Discourse coalitions \\
\hline Driving forces & $\begin{array}{l}\text { rationally formulated interests } \\
\text { belief systems - three types of beliefs: } \\
\text { 1. deep core beliefs: ontological/normative, } \\
\text { 2. policy core beliefs: normative } \\
\text { commitments/causal perceptions within } \\
\text { policy subsystems } \\
\text { 3. beliefs on secondary aspects: concerns on } \\
\text { specific aspects of policy issues }\end{array}$ & $\begin{array}{l}\text { - interests formulated through discourse } \\
\text { - story-lines: } \\
\text { "Narratives on social reality through which } \\
\text { elements from many different domains are } \\
\text { combined and that provide actors with a set } \\
\text { of symbolic references that suggest common } \\
\text { understanding" }\end{array}$ \\
\hline Methods & $\begin{array}{l}\text { - goal-oriented use of resources } \\
\text { - coordinated activity over time }\end{array}$ & $\begin{array}{l}\text { - aim for credibility, acceptability and trust. } \\
\text { if successful, discourse coalitions' story-lines } \\
\text { may reach discursive dominance and } \\
\text { discourse institutionalization }\end{array}$ \\
\hline
\end{tabular}

In Chapter 7 of this dissertation, I draw on the two described concepts of coalitions to determine whether and with what level of success different actors supportive and critical of GM foods formed coalitions that have influenced policy-making. I use the ACF and argumentative approach in complimentary fashion, focusing on the elements from each approach described above. I investigate what types of coalitions exist in the US and EU regarding GM food,

111 Jobert and Muller describe a similar process, which takes place with the help of "mediators" who connect a "referential" (or paradigm) to a specific policy area by making it intelligible to actors within that arena (Jobert/Muller 1987: 71 et seq.). 
and how successful they are. In line with the elements I choose to focus on, I evaluate actors and actor coalitions in terms of their positions and interest, their story-lines, and their activities. I formulate the following proposition on actor coalitions:

\section{Proposition 3: actors and actor coalitions matter}

In the US, actors and actor coalitions supporting GM foods are stronger than those opposing GM foods, and have successfully pushed for permissive regulation of GM foods and crops.

In the EU, actors and actor coalitions opposing GM foods are stronger than those supporting GM food, and have successfully pushed for restrictive GM food and crop policies.

\section{Putting the variables in context}

Several frameworks within the field of policy process theory make reference to the importance of explanatory elements that might be termed "context" factors. For example, according to Sabatier and Jenkins-Smiths's Advocacy Coalition Framework, the policy-making process in a particular policy subsystem can be influenced by factors external to that subsystem. These factors can be "external events" (e.g. changes in public opinion, changes in government, impacts from events within other policy subsystems) or "relatively stable parameters" (e.g. basic constitutional or institutional structure) (Sabatier/JenkinsSmith 1999). Similarly, the funnel-of-causality approach used by Hofferbert identifies a series of causal variables such as socio-economic factors, institutions, and the decision-making process as an intertwined pattern of mutual interactions (Hofferbert 1974). A further interesting approach in this context is that developed by Birkland, who investigates the importance of "focusing events", defined as sudden, relatively uncommon, potentially harmful, concentrated in a particular area or community, and known to policy-makers and the public simultaneously (Birkland 1998).

For the case of GM food policy in the EU and the US, certain factors not addressed explicitly thus far may have a more or less important impact on each of 
the three independent variables introduced above. These factors, which may have an impact on GM food policy, are

- political system attributes and change (e.g. institutional rules, electoral outcomes), and

- shock events and public opinion: "shock events" are important, unexpected occurrences that may have a significant impact on policy and/or public opinion and public trust in institutions (e.g. regulatory failures, release of new scientific information).

Some of the authors reviewed above consider public opinion, in connection with shock events, to be central for explaining the transatlantic rift in GM food policy. For example, Meins (2003) and Bernauer (2003) lay particular emphasis on the role of public opinion or "public outrage" in explaining levels of policy stringency. Public opinion is also at the centre of the research undertaken by Bauer/Gaskell (2002), Durant/Bauer/Gaskell (1998), and Gaskell/Bauer (2001), who treat it as the dependent variable to be explained. Toke (2004) is an example of an author who emphasizes the role of a shock event (the BSE crisis) to explain US, UK, and EU policy differences.

In this dissertation, context factors are not conceptualized as primary explanatory elements. They are not necessarily directly related to GM foods and therefore not always part of the GM food policy subsystem. Their role lies in contributing, sometimes in important ways, to the explanations offered by the three explanatory variables introduced - "preceding policies", "paradigms", and "actors and actor coalitions".

Figure 13 provides a summary of the framework developed in this section to explain the transatlantic rift in genetically modified food policy. The independent explanatory variables suggested by the three propositions coexist within the GM food policy subsystem. ${ }^{112}$ The context factors described above are located outside the policy subsystem. The only causal link that exists within this graphic representation of this dissertation's explanatory framework flows from the policy subsystem to GM food policy, the dependent variable to be explained

112 Sabatier and Jenkins-Smith distinguish "nascent" subsystems which are in the process of forming from "mature" subsystems that have existed for a decade or more (Sabatier/JenkinsSmith 1999: 135). The GM food policy subsystem began forming in the mid-1990s, and can therefore be characterized as relatively new mature policy subsystem. 
in this dissertation. Although this dissertation's goal is not to explain the causalities that link the individual elements, I am attentive to links between individual explanatory variables throughout this study, and draw some conclusions on this subject in the final chapter.

Figure 13: GM food policy differences: analytical framework

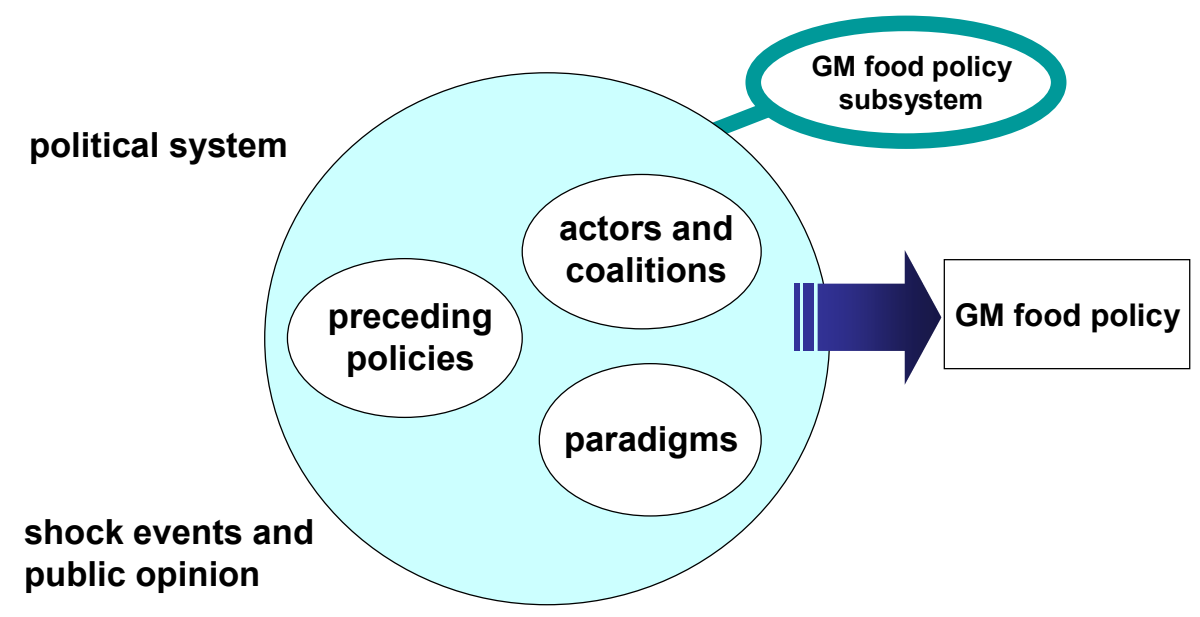




\section{Preceding Policies: From RDNA Research to its APPLiCATIONS}

This chapter presents the empirical results relating to proposition 1, suggesting that current GM food policies are a result of similarly oriented "preceding policies". Underlying this proposition is the historical institutionalist view that history matters for policy outcomes. As defined in Chapter 4, preceding policies refer to earlier policy or policies relevant for and/or leading to a given present policy area. In this section of the study, the focus is on the regulation of rDNA as the policy area preceding GM food. The time period from the mid1990s onwards will be treated in the next chapters.

The empirical findings presented in this chapter contradict the proposition that the US's relatively permissive GM food policy is a result of relatively permissive preceding policy, whereas the EU's relatively restrictive GM food policy is a result of relatively restrictive preceding policy. Instead, empirical enquiry leads to the finding that policies preceding GM food policy in the US and the EU both laid the ground for a "policy switch" or "policy reversal", a phenomenon that occurred in the early 1980s in the US, and in the late 1980s in Europe, and which led to current GM food policies. The US regulated rDNA research in a relatively restrictive manner in the 1970 s, moving on to a relatively permissive GM food policy as of the mid-1980s. The EU, on the other hand, started out with relatively permissive rDNA research regulation in the 1970s and early 1980s, and adopted a relatively restrictive GM food policy as of the late 1980s. These policy switches interrupted a "linear" progression from rDNA to GM food policy in both the US and the EU. It is now necessary to see how rDNA policy brought about these policy switches and if "history matters" in a broader sense in the explanation of current GM food policy.

Gaining an understanding of the paths that led from rDNA research policy to the regulation of its applications is to gain a historical appreciation of the background to present GM food policies, a goal that studies focusing solely on the GM food debate beginning in the 1990s do not pursue. This chapter is 
particularly attentive to three elements: the role of the scientific community, sociopolitical trends, and the content of regulations.

\subsection{United States: from caution to confidence}

In the US, the regulatory period in the 1970s that preceded modern biotechnology applications, including GM foods and crops, was characterized by caution and a relatively restrictive regulation of rDNA research. By the early 1980s, this approach had subsided, giving way to a more permissive regulatory approach, which would remain the basis for GM food regulation in the 1990s and into the new millennium. These trends and the switch from restrictive rDNA research policy to permissive GM food policy were supported and promoted by scientists, society and political actors alike.

\section{From the discovery of the double helix to Asilomar}

In 1953, US scientist James Watson and UK scientist Francis Crick discovered the double helix structure of deoxyribonucleic acid (DNA) at the University of Cambridge, UK. Watson and Crick believed that they had done no less than discover "the secret of life" by shedding light on DNA, the carrier of the code that passes on hereditary characteristics (Watson 1968: 126). In a famous sentence in their article published in Nature, Watson and Crick prophetically noted: "it has not escaped our notice that the specific pairing we have postulated immediately suggests a possible copying mechanism for the genetic material." (Watson/Crick 1953: 738). This sentence implied that the discovery of the structure of DNA might potentially revolutionize research in the fields of molecular biology and, in particular, genetics.

1973 brought the next major milestone on the road towards genetic engineering. In early 1973, US scientists Herbert Boyer from the University of California at San Francisco and Stanley Cohen from Stanford University succeeded in inserting genetic information into a bacterium, which was then copied when the bacterium reproduced. The success of these experiments opened 
up the possibility of conducting research with recombinant DNA (rDNA), a technique which for the first time made the manipulation of DNA possible. ${ }^{113}$

US scientists were thrilled by their new research possibilities, but also apprehensive as they began to reflect on the possible negative consequences of rDNA experiments. As Watson and Tooze put it, "we began to ask whether in the process of possibly discovering the power of 'unlimited good' we might simultaneously be setting the stage for discovering the power of "unlimited bad"' (Watson/Tooze 1981: viii). The hazards discussed were conjectural, that is, not based on actual evidence. Still, US scientists took it upon themselves to ask a series of questions about rDNA techniques, thus breaking with the past scientific practice of forging ahead and only "pulling back if we [found] the savages not of normal size but of the King Kong variety" (ibid.). Questions raised in 1973 included not only possible risks with respect to health and the environment, but also social and ethical issues.

Sheldon Krimsky, a scholar and long-time observer of US biotechnology policy, underlines that "the path towards setting up guidelines on rDNA research was not a linear one. Many events contributed to the process" (interview with Sheldon Krimsky, Tufts University, 25 June 2004, Medford, MA). In hindsight, certain events particularly stand out. One of these was the June 1973 Gordon Research Conference on Nucleic Acids, which "produced the first collective response by scientists on the issue of rDNA experiments" (ibid). Participants at the conference felt strongly enough about the issue to vote for a proposal authorizing conference chairmen Maxine Singer and Dieter Söll to communicate their concerns to the National Academy of Sciences (NAS, a consultative body composed of eminent scientists) in July 1973. This resulted in the setting up of a Committee on Recombinant DNA Molecules, chaired by biochemist Paul Berg. In July 1974, this committee published the famous "Berg letter", expressing "serious concern that some [...] artificial recombinant DNA molecules could prove biologically hazardous" and therefore recommending a moratorium on certain types of rDNA experiments until "attempts [had] been made to evaluate the hazards and some resolution of the outstanding questions [had] been reached" (Berg et al. 1974). As exemplified by the Berg letter, an initiative launched by the

\footnotetext{
${ }^{113}$ For a succinct and useful chronology of scientific discoveries leading up to the rDNA debate, as well as their significance see Rogers 1973: 13-40.
} 
scientific community, many US scientists reacted with great caution and emphasized possible risks of rDNA research.

Paul Berg's 1974 letter had called for an international conference to take place on the topic of the potential hazards of rDNA research. This led to the famous Asilomar conference held between 24 and 27 February 1975 at the Asilomar Conference Center in Pacific Grove, California. The objective of this invitation-only international conference of about 150 molecular biologists was to enable the lifting of the above-mentioned moratorium by agreeing on a statement that could serve as provisional guidelines for conducting experiments involving rDNA. Krimsky notes that the conference was "an illustration of the application of precautionary thinking with respect to laboratory hazards. There were no empirically verified risks at that time. It was all hypothetical" (interview with Sheldon Krimsky, Tufts University, 25 June 2004, Medford, MA).

The last day of the conference, described in detail by a handful authors (Fredrickson 2001, Krimsky 1982, Rogers 1973, Rogers 1975, Wright 1994) produced a document that was adopted to serve as a provisional set of rules by the Recombinant DNA Molecule Program Advisory Committee of the US National Institutes of Health (NIH), newly created in October 1974, and later renamed Recombinant DNA Advisory Committee (RAC or NIH RAC) (Fredrickson 2001: 26). Krimsky aptly summarizes the significance of the 1975 Asilomar conference: the "recommendations that resulted from this conference established the philosophical and practical basis for the guidelines that were issued by the NIH sixteen months later" (Krimsky 1982: 100).

\section{National Institutes of Health Guidelines}

The Recombinant DNA Molecule Program Advisory Committee quickly set about drafting guidelines regulating rDNA research on the basis of the Asilomar conference's conclusions. Its first guidelines, issued on 23 June 1976 and entitled "Guidelines for Research Involving Recombinant DNA Molecules" $" 114$ (National Institutes of Health 1976, "NIH Guidelines" for "Guidelines" for short), applied only to federally funded research. In practice, the

\footnotetext{
${ }^{114}$ For a useful summary of these highly technical guidelines, see Norman 1976.
} 
Guidelines were adhered to by most privately funded researchers as well, and were adopted by a number of US states (Wagner Pfeifer 1997: 148).

The Guidelines prohibited the deliberate release of rDNA molecules into the environment except for small controlled field trials. They defined four levels of physical containment ${ }^{15}$ (P1 to P4, P4 being the most stringent level, and requiring research facilities equipped like biological warfare laboratories) and three levels of biological containment ${ }^{116}$ (EK1 to EK3, EK3 being the most stringent). Experiments involving rDNA techniques were assigned levels of physical and biological containment depending on the types of DNA they used. A further element to note about these first NIH Guidelines is their "encyclopaedic approach" which involved "trying to envisage every possible category of recombinant DNA experiment and laying down for each of them appropriate combinations of physical and biological containment" (Tooze 1978). According to Watson and Tooze, the criteria used for assigning levels of containment were developed arbitrarily and were not based on scientific evidence. They write that underlying the Guidelines was the "scientifically unsubstantiated conclusion that the closer the evolutionary relationship between humans and the species whose DNA was being used, the greater the conjectural hazards" (Watson/Tooze 1981: 64). Moreover, the NIH Guidelines required certain types of experiments that were taking place at the time of the Guidelines' announcement to be halted and destroyed. Mark Cantley, an expert on the transatlantic debate on genetic engineering, comments that

"the creation of the NIH RAC and of its Guidelines was a classic example of applying what we now call the precautionary principle in Europe, although that language was not used in the 1970s. After a few years, as a result, [US regulators] were ready to say: there is no need for new legislation. We can handle the technology with existing statutes and agencies." (interview with Mark Cantley, European Commission, 7 September 2004, Brussels).

\footnotetext{
115 Physical containment refers to the use of special facilities, equipment and procedures to prevent the escape of organisms into the environment.

${ }^{116}$ Biological containment involves the use of organisms that have been genetically altered so that they have little chance of surviving a release into the environment.
} 
Many US and European scientists judged the NIH Guidelines to be very stringent, more so than the rules agreed at Asilomar had been (Norman 1976, Watson/Tooze 1981: 65). As a result, US scientists felt at a disadvantage when competing internationally. In 1978, Stanley Falkow, a professor of microbiology at the University of Washington, vividly expressed this sentiment among US scientists in a letter to NIH Director Donald Fredrickson: "It is painfully obvious that because of the very restrictive nature of the NIH guidelines, [...] American biologists can no longer expect to keep pace either with Western European or East European science. [...] the guidelines adopted by the European community and the USSR [the Union of Soviet Socialist Republics] retain a flexibility and a scientific reality that is absent from our own" (Falkow 1978). With hindsight, however, observers like Mark Cantley praise the NIH Guidelines because they "preserved freedom of scientific inquiry while allaying public fears of genetic manipulation" (interview with Mark Cantley, European Commission, 7 September 2004, Brussels).

\section{Sociopolitical context: anti-establishment and environmentalist}

US scientists' and regulators' cautious reaction to rDNA research must be understood within the US social and political context of the 1970s. When US scientists first developed rDNA techniques in 1973, US society was in a period of profound social and political upheaval. Among other changes, this period brought with it greater distrust of science and the beginning of the US environmental movement.

In the post-World War II era and until the 1960s, the United States was a very hospitable environment for science and technology investment and innovation. The 1950 establishment of the National Science Foundation (NSF), the US's research funding agency, underlined the importance of science and, specifically, provided federal funding for projects in scientific fields. US government support for science had increased steadily from 1945 to the late 1960s (Wright 1994: 21 et seq.). This was in large part a result of the US's Cold 
War objective of outdoing the Soviet Union in terms of science and technology. ${ }^{117}$

The use of the atomic bomb in Hiroshima and Nagasaki to end World War II in the Pacific was followed by the race by the US and the USSR to develop ever more powerful nuclear weapons. Despite the doubts and fears that accompanied these developments, during the 1950s and early 1960s, science was largely perceived as "inherently virtuous and as the engine of human progress" (Krimsky 1991: 15). Scientists tended to be regarded by government, the public and academics alike as impartial, disinterested and non-partisan. Merton's famous "ethos of science" concept, first developed in 1949, illustrates this view (Merton 1968 [1949]). Merton described science as a profession different from all others by its "ethos of science""118, defined as the "complex of values and norms which is held to be binding on the man of science" (Merton 1968 [1949]: 605). Polanyi's "Republic of Science" (Polanyi 1962) is a further example emphasizing that "the whole outlook of man on the universe is conditioned by an implicit recognition of the authority of scientific opinion" (Polanyi 1962: 60). Science was also seen as "speaking truth to power", i.e. as giving policy-makers the best possible information to make good policy (Price 1965).

The late 1960s and the 1970s brought an important change in the status of science in the US. These years were an era of great social unrest, a public reaction to various social inequalities, especially in connection with race or gender, and to government policies (Vietnam War) and scandals (Watergate). In the mind of a large segment of the public, scientists, who had enjoyed more or less unquestioned authority in the 1940s and 1950s, now became part of the objectionable "establishment", conspirers in war and injustice.

Scientists themselves participated in this critical stance and questioned the authority they enjoyed. As Krimsky notes, "[b]y the 1970s, many scientists were influenced by the moral indignations of the Vietnam War and the arms race. The

${ }^{117}$ In this context, an event that shook the US and galvanized it to increase its efforts was the 1957 so-called "Sputnik shock", when the Soviet Union succeeded, before the US, in sending the first satellite ever (named Sputnik) into space.

${ }^{118}$ Merton's "ethos of science" is made up of "universalism" (impersonal criteria for the judgment of science, accessibility to all), "communism" (common ownership of science), "disinterestedness" (search for 'truth', not guided by financial of other special interests), and “organized skepticism” (habit of questioning) (Merton 1968 [1949], Merton 1973). 
moral responsibility of science became a prominent theme [...]" (Krimsky 1991: 15). US scientist Watson confirms that in the early 1970s, when rDNA techniques became accessible, scientists themselves felt the need to control their activities more closely: "many academics thought that science was already out of control", a feeling "widely shared" by the public and government (Watson/Tooze 1981: viii). The result, as summarized by M.E. Jones in her dissertation on the early years of US agricultural biotechnology policy, was that, in contrast to the 1940s and 1950s, in "the case of rDNA, some public interest groups began to look to the federal government not only for funding of science, but for protection from science" (Jones, M.E. 1999: 39). As a result of increasing public distrust of government, the postwar supremacy of science was increasingly questioned. Jones described this trend as an "erosion of Public Trust in Science" (Jones, M.E. 1999: 32).

At the same time and interrelated with these trends, another powerful movement was gaining force: environmentalism, a social and political movement directed towards the preservation and restoration of the natural environment (de Steiguer 1997, Dunlap/Mertig 1992, Sale 1993). In 1962, Rachel Carson’s “Silent Spring" alerted a wide readership, especially in the US, to the impact on the environment of chemicals used as pesticides. Carson asked how "intelligent beings [could] seek to control a few unwanted species by a method that contaminated the entire environment and brought about the threat of death even to their own kind" (Carson 2002 [1962]: 8). She also criticized science's "arrogant" goal of controlling nature, and concluded that it

"is our alarming misfortune that so primitive a science has armed itself with the most modern and terrible weapons, and that in turning them against the insects it has also turned them against the earth" (Carson 2002 [1962]: 297).

By the end of the 1960s and early 1970s, government and public concern for environmental problems had grown considerably, and the institutionalization of environmentalism was under way. This new consciousness culminated in the 
National Environmental Policy Act (NEPA) ${ }^{119}$ of 1969 and the creation of the Environmental Protection Agency (EPA) in 1970.

Influenced by this sociopolitical context, the US debate on rDNA research consisted of an intense dialogue and search for consensus among scientists, political institutions, and civil society on how science and scientific discovery should be dealt with in a democracy. This debate was lively during the years leading up to Asilomar, and exploded with the announcement of the 1976 NIH Guidelines (Wright 1996: 254). Actors involved included not only scientists and regulatory agencies, but also the media, the public and many organizations and individuals promoting or criticizing rDNA research. Critics and actors taking a cautious approach included prominent scientists such as Robert Sinsheimer, Erwin Chargaff, and George Wald (all academics), Jeremy Rifkin (leftist environmentalist and spokesman for the critical organization People's Business Commission). Other critical actors were Friends of the Earth, Environmental Defense Fund (environmental groups), Science for the People (a leftist group including scientists), the Coalition for Responsible Genetic Research (scientists), groups within the US Congress, and some US state legislatures. Groups and individuals emphasizing the potential of rDNA research and therefore trying to prevent unduly strict rules included many university departments and scientists, for example James Watson and Joshua Lederberg, the National Institutes of Health and the National Academy of Sciences. The US media, including prominent national newspapers such as the New York Times and the Washington Post, as well as popular magazines such as Rolling Stone strongly publicized the rDNA debate question, thus calling the public's attention to the issue.

The tone of the debate heated up considerably as a result of an episode that took place in Cambridge, Massachusetts (MA) during the second half of 1976, after the first NIH Guidelines had been announced (accounts in Watson/Tooze 1981 and Krimsky 1982). Harvard University's Molecular Biology Department was proposing to convert some of its laboratories into "P3 laboratories", designed for rDNA experiments considered to be relatively highrisk by the NIH Guidelines. This plan was ardently debated within Harvard

119 NEPA established a national policy to protect the environment, created a Council on Environmental Quality (CEQ), and required Environmental Impact Statements (EIS) for major federal actions affecting the environment. 
University itself, and quickly made it onto the agenda of Cambridge's City Council, which, after a passionate debate in the summer of 1976, declared a three-month moratorium on all rDNA experiments. The City Council also set up a review board, which determined that all future rDNA experiments would need to comply not only with NIH Guidelines, but also with additional rules to be set up by the City of Cambridge. The Cambridge events signaled that US states and cities would be the ones to regulate if the federal government did not. As Krimsky notes: "More than anywhere else, the events in Cambridge dramatized the role of public involvement in the debate [...] it was the body politic against the intelligentsia, the ordinary folk against the elites. There was far more at stake than rDNA research. A decision-making apparatus was on trial" (Krimsky 1982: 298).

\section{Transition into the $1980 \mathrm{~s}$}

By the late 1970s, a growing scientific consensus had been reached on rDNA. Scientists in the US and abroad had by now had several years to test the use of rDNA techniques and had become increasingly convinced that US scientists' initial caution had been overdone. Starting in 1978, the rules for rDNA research were progressively relaxed in terms of the levels of physical and biological containment imposed. Watson and Tooze remember that the 1978 revision "marked a significant change in attitude" (Watson/Tooze 1981: 338). The Proposed Revised Guidelines of 28 July 1978 stated that "factual bases for the greater stringency of U.S. NIH Guidelines [in comparison with other countries' guidelines]" could not be shown and that there was "growing sentiment that the burden of proof [was] shifting toward those who would restrict rDNA research" (National Institutes of Health 1978). These guidelines contained a series of possible exemptions from provisions contained in the original Guidelines, and reclassified many experiments within lower containment levels.

In the early $1980 \mathrm{~s}$, these scientific developments gave the US federal government the necessary basis to declare genetic engineering to be safe, and to announce that comprehensive regulation on rDNA applications would not be necessary. The 1984 Proposal for a Coordinated Framework recalled that 
"In 1974 the National Institutes of Health (NIH) chartered the recombinant DNA Advisory Committee (RAC) to provide scientific advice and in 1976 developed the NIH Guidelines for Research Involving Recombinant DNA Molecules. It was reasoned that a cautious approach to this research was essential to assure safety while still fostering the advancement of this new technology. [...] Experience gained in rDNA laboratory research has mitigated many concerns about risk, thus allowing modification of the original guidelines and oversight mechanisms" (Office of Science and Technology Policy 1984: 50857)

This new announced policy was part and parcel of a larger political vision introduced by Ronald Reagan, who had been elected US President in 1980 and who remained in office until 1988. Reagan's primary goals for the United States were strengthening its defense and improving its economy by increasing its international competitiveness. One of his methods to achieve this goal was supply-side economics, a macro-economic theory and strategy emphasizing tax cuts and business incentives in order to encourage international competitiveness, and to increase productivity and employment. ${ }^{120}$

One of the sectors that benefited from these policies was the biotechnology industry. The Reagan administration was particularly supportive of this emerging sector for which it saw great potential. M.E. Jones confirms that the Reagan administration's goal was to “develop rDNA into a strong, competitive American technology" (Jones, M.E. 1999: 261). Krimsky notes that, supported by these policies, "[t]he increase in the number of new biotechnology enterprises [...] between 1973 and 1987 was something of a phenomenon" (Krimsky 1991: 30). He further notes that for the federal government,

"[e]arly investments were in the techniques and the scientists who had control over them, not in the products per se. Viewing the emergence of the industry from this point of view, it was irrelevant which products succeeded, failed, or met a social need. This was truly a technological revolution. The failure of biotechnology was out of the question whether

\footnotetext{
${ }^{120}$ Reagan's policies were a manifestation of a shift of a large part of the US Republican Party towards conservativism. The origins of the post-war resurgence of this ideology, based on conservative economic and social policies and values, and later termed "neoconservativism", are usually traced back to Barry Goldwater, a US Senator from Arizona who ran for president in 1964 on an extreme anticommunist and fiscally conservative Republican platform.
} 
or not there were existing needs or favorable markets" (Krimsky 1991: $31)$.

Part of Reagan's economically conservative vision was that economic competitiveness was best enhanced if the market was left to regulate itself as much as possible. Deregulation, small government and a "no new law" philosophy became guiding principles of US policy in the 1980s. Scholar and commentator on the GM food debate Calestous Juma explains that

"during the Reagan era, there was a clear decision to use existing laws to regulate biotechnology instead of creating new ones. New laws would have sent the message that biotechnology was creating new products, and the Reagan Administration wanted to avoid that impression in order to support the biotech industry" (interview with Calestous Juma, Harvard University, 25 June 2005, Cambridge, MA).

For the area of agricultural biotechnology specifically, M.E. Jones writes that Reagan "had an intense interest in [...] increasing the autonomy and capability of the private sector" (Jones, M.E. 1999: 227). In 1984, OSTP stated that its regulatory objective was to enable a "coherent and sensible regulatory process, [...] intended to minimize [...] delays, overlaps and inconsistencies" (Office of Science and Technology Policy 1984: 50857). In accordance with these goals and preferences, although the late 1970s had

"yielded over a dozen bills in Congress [on the regulation of biotechnology ...], no legislation was passed. The White House was very active in avoiding that it ever came to a vote" (interview with Sheldon Krimsky, Tufts University, 25 June 2004, Medford, MA).

The early 1980s also brought with them a sociopolitical change. Social and environmental protest receded into the background and to the margins of US society. After a short but sharp recession in 1981-1982, resulting from combating the "stagflation" (high inflation combined with a stagnant economy) of the late 1970s through an increase in interest rates, the Federal Reserve slashed interest rates in 1982 and the US economy picked up in 1983. After years of stagflation, US citizens were ready to prosper instead of protest. What is more, the 1970 s had been a period of intense debate and consensus-building with respect to genetic 
engineering. US civil society had fought its "DNA wars" and had seen scientists and regulators come the conclusion that the risks of rDNA research had been overestimated. It was ready to accept the product-based policies that the US announced with the 1986 Coordinated Framework, and which will be discussed in the next chapters. ${ }^{121}$

\subsection{Europe and the EC: from guarded support to precaution}

A reverse policy switch took place in Europe as compared to the US case. In the 1970s and early 1980s, although some European countries adopted relatively strict rules on rDNA research, the European Community (the EU's predecessor until 1993) avoided restrictive rules on rDNA research technologies. By the end of the 1980s, this guarded and somewhat passive supportive of rDNA research had changed into a more active and far more precautionary approach to the regulation of GMOs.

\section{European scientists and $r D N A$ research}

The 1973 news that recombinant DNA techniques were possible triggered the same mixture of excitement and apprehension in Europe as it did in the US. In part because it had not taken place in Europe, however, concerns with rDNA methods were less widespread and feelings of responsibility less pronounced. Overall, European scientists were less cautious and more reassuring about rDNA than their colleagues in the US. The voluntary moratorium recommended by the 1974 Berg letter drew mixed reactions by European scientists. While some welcomed the approach, others felt that it was too restrictive, especially since there was no actual evidence of risks connected with rDNA research. Many prominent European scientists favored some form of control of the new

${ }^{121}$ As documented by several authors (Jones 1999, Sheingate 2004, Cantley 1995), today's permissive, product-based US policy on agricultural biotechnology was not put in place without an institutional battle between APHIS and EPA. In essence, the more cautious and processoriented EPA, which had the sympathies of many members of the US Congress, lost this institutional battle against APHIS, which was more product-oriented and fully backed by the White House. As Sheingate underlines, "an alternative outcome [to this battle] would have placed U.S. policy on a path that resembles the more precautionary approach in Europe today" (Sheingate 2004: 3). According to Jones, the USDA won the battle because "the Reagan Administration feared that if EPA were allowed to regulate rDNA, the technology might be strangled in its infancy" (Jones, M.E. 1999: 168). 
technology, but viewed a moratorium as a hindrance for scientific progress ("Europeans Divided on E. Coli Manipulation" 1974: 3). Rather than focusing on rDNA's conjectural risks like many US scientists, they underlined the huge potential of this new research method.

The European Molecular Biology Organisation (EMBO), founded in 1963 in Ravello, Italy, was an especially important voice on the issue of rDNA research. At a reaction to 1973 announcement of rDNA techniques and possibilities, EMBO took a permissive approach, driven by the conviction that since World War II, European countries "suffered from a 'historical backwardness', a supposed delay compared with the 'normal' historical development of the life sciences" (Strasser 2002: 546). In particular, EMBO portrayed molecular biology as being "well developed in the United States, but not in Europe" (Strasser 2002: 548), and therefore promoted Europe's competitiveness in this field on every possible occasion. As a result, EMBO "took a liberal position on the regulation of this scientific practice and downplayed the risks of recombinant DNA experiments" (Strasser 2003: 543). For example, in February 1976, EMBO stated that it believed the conjectural risks discussed in connection with rDNA to be highly unlikely (European Molecular Biology Organization 1976).

The European Science Foundation (ESF), set up in 1974, took a similar position. Bringing together European scientists involved in rDNA research, it recommended following the more flexible UK guidelines (see below) instead of US guidelines, and expected rapid evolution of the field. By 1981, ESF concluded that "recombinant DNA work per se entails no significant novel biohazards" and that "there is no scientific justification whatsoever for new legislation specific for recombinant DNA research" (quoted in Cantley 1995: 524 et seq.). 


\section{UK Code of Practice and EC Recommendation}

The "Berg letter" triggered an immediate reaction by the United Kingdom government, a pioneer of rDNA regulation within Europe. ${ }^{122}$ It set up an expert committee on rDNA technology in the summer of 1974. This committee issued a report on rDNA in January 1975. According to Wright, its "overall tone report was one of optimism and reassurance" (Wright 1974: 143). The so-called Ashby Report (named after its chair Eric Ashby) emphasized that the moratorium triggered by the Berg letter could "be no more than a pause, because the techniques open[ed] up exciting prospects for both science and for its applications to society" (Ashby Working Party Report 1975: 6.8). It suggested that potential risks "would probably be comparable to those presented by ordinary pathogens" (Wright 1994: 143). The Ashby report advocated voluntary controls of rDNA experiments, but not regulation. The control mechanisms suggested included biological and physical containment.

As a follow-up to the Ashby report, a working party was set up under Sir Robert Williams to write a code of practice, which was finalized in August 1976, shortly after the NIH's first guidelines. In this first Code of Practice, the UK took a very stringent approach. The Williams Working Party defined four physical containment levels, the highest of which was more demanding than the NIHRAC's P4 level. However, the Williams Report was less comprehensive and more flexible in the sense that it did not attempt to cover every possible experiment in the way that the NIH-RAC Guidelines did. It also recommended that an advisory and surveillance body be set up. This resulted in the Genetic Manipulation Advisory Group (GMAG), inaugurated in January 1977.

By 1979, the GMAG had introduced a new risk assessment scheme which re-categorized experiments and generally made rules less stringent than the NIHRAC guidelines. As Cantley puts it, the GMAG's revised Code of Practice "diminished scientific concerns about overzealous safety committees, unnecessary delays, and excess disclosure of ideas to competitors" (Cantley 1995: 517). During the second half of the 1970s, many European countries

${ }^{122}$ The case of the UK is described by Cantley 1995, Gottweis 1998, Watson/Tooze 1981, and in great depth by Wright 1994. 
followed this trend and set up national ethics committees to discuss the question of guidelines for rDNA research. Most of them adopted rules based on either the UK Code of Practice or on the NIH Guidelines (Watson/Tooze 1981: 305 et seq.).

In contrast, oversight activity at the European Community level was relatively modest and took shape late in comparison with the United States and individual European countries. This was primarily because the idea of harmonizing European national research policies and pooling of resources to finance research at the European level was still in its infancy during the 1970s. Research policy was viewed mainly as a national policy area. Until the Single European Act of 1986, there was no legal basis under the 1957 Treaties of Rome to establish a European Research and Development (R\&D) policy. Even in the late 1970s, "European Community R\&D was a very modest affair indeed", which focused mainly on nuclear research (Ford/Lake 1991: 38 et seq.).

Nevertheless, the European Commission took notice of the issue of rDNA research. Its Directorate-General (DG) for Science, Research and Development, then called DG XII (now DG Research), took on the issue although it had not yet built up systematic expertise in biotechnology. In December 1978, when individual countries were already revising their first rules on rDNA research, DG XII drafted a "Proposal for a Council Directive establishing safety measures against the conjectural risks associated with recombinant DNA work" (Cantley 1995, Fredrickson 2001). This proposal emphasized the potential benefits of rDNA research, as well as the fact that possible risks were conjectural. It proposed rDNA experiment notification to and authorization by national authorities that would be obliged to develop national categorization systems.

In the meantime, US experiences with rDNA research had accumulated and slowly led to the conclusion that the new technology harbored fewer unknown hazards than previously feared. In 1979, US NIH Director Donald Frederickson visited Günter Schuster, the Director-General of DG XII in 1979, to recount the US experience with the NIH Guidelines. In his memoir, Fredrickson remembers having told Schuster that "[in] sum, [he] preferred a simple rule and chose volunteerism rather than inflexible regulation" (Fredrickson 2001: 248). Fredrickson further recalls that: 
"[a]t the end of our conversation, I had a distinct impression that the Director-General's convictions about his plan [of a Directive on rDNA research] were less certain - perhaps leaning toward seeking something less than a directive, perhaps, rather, a recommendation of the Council" (ibid.).

In parallel, within DG XII, a "consensus was developing that some of the initial expressions of scientific (and other) concern had been exaggerated" (Cantley 1995: 519). In 1980, the suggested directive was substituted with a non-binding recommendation, approved in 1982. Council Recommendation 82/472/EEC suggested notification to national authorities but removed provisions discussing authorization by Member States (Council of the European Union 1982).

\section{Bridging the transatlantic science and technology gap}

It was not only the lack of a strong institutional mandate that determined the low level of EC activity in the area of rDNA research. The 1970s and early 1980s were characterized by a focus on "catching up" with the US in terms of science and technology. As a result of the effort of post-World War II reconstruction, Western European governments could not afford to invest as large amounts of resources in science as the United States. Wright (1994) illustrates this point for the case of the United Kingdom, and Strasser points out that early postwar transatlantic networks on molecular biology were very important for European researchers: in circulating "people, organisms, materials and ideas", these networks "made a crucial difference in Europe, where resources were still scarce in the years immediately after the war" (Strasser 2003: 541).

As a result, in the 1970s in Europe were dominated by the idea that biotechnology needed to be promoted in order for Europe to bridge the transatlantic science and technology gap with the United States. The "starting point of a European biotechnology policy was the Commission's insight [...] that the Community displayed a technological backwardness with respect to the USA and Japan [...]" (Nollert 2000: 210). EC-level policy activities regarding biotechnology, such as the Commission's Biomolecular Engineering Programme of 1975, were consistently supportive of developing genetic engineering (Nollert 
2000, Schweizer 1996). For example, the 1983 report "Biotechnology: The Task of the Community" focused on reinforcing the biotechnology industry rather than controlling it by underlining its problems of fragmentation, shortage of engineers and scientists, and lack of funding (Nollert 2000: 212). As a result of this sociopolitical orientation, putting in place a restrictive research policy was not at the top of the European policy agenda, and public scrutiny did not focus on the authority of science. ${ }^{123}$

In comparison to the US situation, the European debate on rDNA research was therefore limited both in tone and in terms of actors involved. Individuals and groups actively involved in the debate were scientists directly concerned by the developments in the field of rDNA research, and scientists' professional associations. The European media was less attentive to the issue of rDNA research than the US media, and the European public was therefore less informed and involved. Watson and Tooze recall that "[b]y and large, $[\ldots]$ the debate in Europe was more leisurely [...]" (Watson/Tooze 1981: 305). From their scientists" perspective, they write that the European rDNA debate moved "not only more slowly, but more dispassionately" and judge that it was "easier for Europeans to avoid confusing the limited issue with more diffuse and emotional ones concerning the uncomfortably current relationship between science and society" (Watson/Tooze 1981: 205).

In contrast to the United States, therefore, a full-blown debate on the role and control of science within a democratic society did not take place in Europe. A debate was launched in the European Parliament when the Commission submitted its proposal for a directive on rDNA research in 1978, but failed to fully develop when the proposal was withdrawn. As it turned out, however, the debate was only being postponed to the late 1980 s.

\section{Environmentalism and the rise of anti-GMO sentiment}

By the mid-1980s, when the EC faced the need to regulate first applications of rDNA technology, the environmental movement had already

${ }^{123}$ The 1970s in Europe were also a period of social and political upheaval, which, however, did not focus on science and technology. The environmental movement was in its beginning stages, and would become seriously influential only in the 1980s. 
become quite influential. In Europe, the beginnings of modern environmentalism date back to the late 1960s and 1970s ${ }^{124}$ (Dalton 1994, Rootes 2003), but public awareness regarding environmental issues did not peak until the late 1980s, after the nuclear disaster of Chernobyl in 1986. According to Dalton, "Chernobyl and its by-products convinced many Europeans that the environmentalists' claims were not mere political rhetoric, and this forced political leaders to respond to public demands for environmental reform" (Dalton 1994: 44).

Since the late 1970s, the environmental movement had spurred the creation of "green" parties, which, by the mid to late 1980s were on the rise in several European countries. The first green party in Europe emerged in 1973 in the UK. In 1979, what was later to become the Swiss green party became the first green party in Europe to gain representation in is national parliament. Other European green parties followed, with parliamentary representation gaining impact and momentum by the late 1980s. Important examples are the Belgian green parties ECOLOS and Agalev (now Groen!) and Die Grünen of Germany, first elected to their national parliaments in 1981 and 1983 respectively (Bomberg 1998, Müller-Rommel 1989, Rihoux 1999).

Several European green parties began to cooperate as early as 1984, when the European Coordination of Green Parties was founded. In 1993, it was transformed into the European Federation of Green Parties or European Greens. Together with the European Free Alliance, consisting of green parties from European regions, they make up the European Parliament's 'European Greens European Free Alliance". European green parties were first represented in the European Parliament in 1984.

The growing voice of green movements and parties meant that the environment gained the status of a policy area in its own right. At the European Community level, environmental policy began to take shape with the launch of the first Environmental Action Programme in 1972. A further important turning point came in 1987 with the Single European Act, which added a title specifically

${ }^{124}$ For example, issues such as acid rain and nuclear energy were discussed by newly formed environmental groups starting in the 1970s. 
on the environment to the Treaty establishing the European Community (consolidated text, 2002). ${ }^{125}$

The connection between the rise of environmentalism and both rDNA research and GM food policy as political issues was that European environmentalists and green parties strongly questioned the need for research using rDNA, and for its use in applications. Non-governmental organizations (NGOs) and green parties forcefully turned against genetic engineering. For example, "green" Members of the European Parliament (MEPs) campaigned against biotechnology "as an irreversible, ominous way forward” (Levidow et al. 1996: 137). In short, "environmentalists succeeded in stigmatizing GMOs as an abnormal danger" (Levidow et al. 1997: 478, see also Gottweis 1995) and "[b]y the late 1980s, the new biotechnology faced a legitimacy problem" (Levidow et al. 1996: 136). Mark Cantley convincingly summarizes this phenomenon as follows:

"[Environmentalists] were strategically imaginative. They had vision. They saw an opportunity. They saw that they could put forward a proposal for legislation [on GMOs], which would oblige the Member States to reinforce their environment ministries, which in turn would give those ministries the budget and the authority to implement rules nationally. They said: if you come to Brussels and vote this through, we all get more power and authority" (interview with Mark Cantley, European Commission, 7 September 2004, Brussels).

Member States and the European Parliament as a whole were also questioning the need for genetic engineering. In 1986, Denmark passed a law banning GMO releases (Danish Ministry of the Environment. Environmental Protection Agency 1986). A further example was the German government's commissioning of an in-depth report on genetic engineering completed by the German Parliament between 1984 and 1987, which raised many ethical and societal questions and polarized the German debate on GMOs (Enquete-

${ }^{125}$ This title (Title XIX of the consolidated Treaty establishing the European Community) defines environmental principles and goals (e.g. preserving and protecting the environment, protecting human health, prudent and rational utilization of natural resources), as well as methods to achieve them. 
Kommission 1987). ${ }^{126}$ A further important signal was given by the European Parliament's Viehoff Report, named after its rapporteur, resulting in a resolution demanding a complete ban on GMO field releases until Community Directives were in place (European Parliament 1987, Cantley 1995: 543).

\section{Putting in place Directive 90/220}

It was within this increasingly environmentally conscious and GMOhostile context that the issue of rDNA research and its pending applications came to be regarded and dealt with by policy-makers as an environmental issue to be addressed in a precautionary manner. This development stood in contrast with the international discussion on the safety of rDNA in food which had reached a consensus in 1986 in the form of a report by the Organisation for Economic Cooperation and Development (OECD) entitled "Recombinant DNA Safety Considerations", and also known as the "1986 Blue Book" (Organisation for Economic Co-operation and Development 1986: 42). This report stated explicitly that " $[t]$ here is no scientific basis for specific legislation for the implementation of rDNA techniques and applications" (ibid.).

Until the mid-1980s, the question of regulating rDNA and its applications had been dealt with primarily by the Commission's Directorate General for Science, Research and Development (DG XII). As the question of regulating biotechnology applications became more and more pressing, however, and "[p]erhaps anticipating further public controversy", the Commission designated DG Environment (DG XI) to become "chef de file" for GMO regulation from DG XII, including the task of drafting a directive on the deliberate release of GMOs into the environment (Levidow et al. 1997: 478). ${ }^{127}$ As a DG that traditionally did

\footnotetext{
${ }^{126}$ On the German case, Margaret Mellon suggests that "deeply rooted opposition [...] from Germany [...] objected to this technology at its core. Germans [...] proceeded from the standpoint that what had been abused in the past (eugenics during Nazism) was likely to be abused in the future" (interview with Margaret Mellon, Union of Concerned Scientists, 9 June 2004, Washington, DC).

${ }^{127}$ Within the bureaucratic language of the European Commission, "chef de file" status refers to a particular Directorate-General being in charge of a certain policy area, legislative initiative, etc. Mark Cantley clarifies that for Directives $90 / 219$ on the contained use of GMOs, DGs III (enterprise and industry) and XI (environment) were joint chefs de file, but that DG III in practice left DG XI largely in charge of both Directive 90/219 and 90/220 (interview with Mark Cantley, European Commission, 7 September 2004, Brussels).
} 
not focus on policy-making, but rather on the promotion and funding of research, DG XII did not contest the removal of its chef de file status regarding GMOs:

"The culture of DG XII, especially in its earlier decades, was scientific in its sympathies and roots. They [DG XII civil servants] were reluctant legislators in 1978, glad to retire from such matters in the mid-1980s" (Cantley 1995: 669).

GMO policy observer and scholar Rene von Schomberg ${ }^{128}$ further notes that

"it was logical for DG Environment to become chef de file for the GMO directive on deliberate release in the late 1980s since the issues to be addressed were perceived as being mainly environmental at this stage. This development was not contested" (interview with Rene von Schomberg, European Commission, 2 September 2004, Brussels).

Observers of and participants in the development of the EC's GMO policy in the late $1980 \mathrm{~s}$ argue that the result of this shift in administrative responsibilities was very important for the EC's ensuing move towards a precautionary and process-based GM food policy. While DG XII had dealt with rDNA experiments as an RTD and competition issue, DG XI saw rDNA experiments and applications through an environmental protection lens.

As a result, in 1990, the Council approved Directive 90/219 on contained use, and Directive 90/220 on the deliberate environmental release of GMOs. Von Schomberg comments that

"the passage of Directives 90/219 and 90/220 in 1990 meant the introduction of horizontal ${ }^{129}$ regulation of GMOs. This was an important novelty for European GMO regulation, and is one of the main elements that distinguishes EU and US policy on GMOs" (interview with Rene von Schomberg, European Commission, 2 September 2004, Brussels).

\footnotetext{
${ }^{128}$ In the interview he granted me on 2 September 2004 in Brussels, Rene von Schomberg spoke as a scholar and long-time observer of GMO politics, and did not in any way represent the positions of the European Commission.

${ }^{129}$ As mentioned in Chapter 3, in this case "horizontal" means referring to GMOs generally, instead of relating to a vertical or sector/product-specific area like food, plants, or pharmaceuticals.
} 
Directive 90/220 was relatively restrictive in that it was process-based and foresaw a complex authorization process for field trials and for the commercialization of GMOs. These basic principles of EU GMO policy are still in place today.

\subsection{Conclusion}

This chapter has described the policy phase during which the United States and the European Community were faced with the task of regulating rDNA research and therefore of creating the policies that preceded GM food regulation. It has been shown that today's US and EU GM food policies build on very different regulatory and sociopolitical experiences, and that therefore "history matters" in a broad historical institutionalist sense. Proposition 1, however, is not confirmed: current relatively permissive GM food policy in the US does not build on or derive from permissive rDNA research policy, just as today's restrictive EU policy is not a continuation of previous restrictive EC policy on rDNA experiments.

As this chapter has shown, the opposite is the case. A policy switch has taken place, in which the US started out with restrictive policies that became permissive, whereas the EU began with a permissive situation that became restrictive. On the basis of this finding, it can be argued that the US government built on previous regulatory experience with restrictive rDNA policy in developing the 1986 Coordinated Framework, which laid down a permissive regulatory oversight of its rDNA applications. In contrast, a comparable experience did not exist at the European level, and this in turn can be seen as having provided the necessary space for the development of restrictive regulation in the late 1980 s and early 1990 s.

As this chapter shows, the empirical evidence on this "policy switch" is complex. Table 13 attempts to summarize its most salient points. The US developed restrictive guidelines on rDNA research in the 1970s in midst of an intense and wide-ranging public and media debate on the risks and benefits of genetic engineering. With the passage of time and increasing confidence that rDNA research was not an unacceptable hazard, these rules were relaxed, and the 
public debate subsided. By the early 1980s, a scientific and societal consensus had emerged, which paved the way for later developments. This new era was dominated by neoconservative economic and research policies favoring relatively permissive regulation of biotechnology applications such as GM foods.

EU regulation of GMOs builds on very different experiences. When rDNA research became possible in the 1970s, the EC was struggling to catch up with the US in terms of science and technology excellence and progress, and therefore avoided strict oversight of rDNA research, a stance that can also be explained by the fact that some EC Member States were themselves regulating rDNA research. An incipient European-level debate launched in the European Parliament in early 1980 was thwarted when the Commission substituted its proposal for a Directive on rDNA research with a non-binding Recommendation. In the mid to late 1980s, however, regulating GMOs had become necessary because first applications of modern biotechnology were in the pipeline. In Europe, this process coincided with the rise of the environmental movement and green parties, which in turn galvanized anti-GMO sentiment in Europe. This constellation resulted in the process-based and relatively restrictive policies which have remained the basis of the EU's GM food policies into the present.

Table 13: Preceding policies in the United States and the European Community

\begin{tabular}{|c|c|c|}
\hline & United States & European Community \\
\hline 1970s & $\begin{array}{l}\text { anti-establishment sentiment, rise of } \\
\text { environmentalism } \\
\text { relatively restrictive NIH Guidelines on } \\
\text { rDNA research, progressively relaxed }\end{array}$ & $\begin{array}{l}\text { concern with transatlantic science and } \\
\text { technology gap } \\
\text { planned regulation of rDNA research } \\
\text { withdrawn; Recommendation } 82 / 472 \\
\text { instead }\end{array}$ \\
\hline 1980s & $\begin{array}{l}\text { supply-side economics, "no new laws", } \\
\text { support of the biotechnology industry } \\
1984 \text { Coordinated Framework: } \\
\text { applying existing laws to rDNA } \\
\text { applications }\end{array}$ & $\begin{array}{l}\text { Influence of green politics and policy; } \\
\text { skepticism about genetic engineering } \\
1990 \text { Directives } 90 / 219 \text { and 90/220 on } \\
\text { GMOs: horizontal legislation and } \\
\text { precautionary stance }\end{array}$ \\
\hline Summary & $\begin{array}{l}\text { from restrictive guidelines on rDNA } \\
\text { research to permissive regulation of its } \\
\text { applications }\end{array}$ & $\begin{array}{l}\text { from sparse rules on rDNA research to } \\
\text { precautionary regulation of GMOs }\end{array}$ \\
\hline
\end{tabular}




\section{PARADigms: UnCOVERING UNDERLYing BeliefS}

This chapter discusses and evaluates the role of paradigms, a concept introduced in Chapter $4 .^{130}$ It presents empirical elements that confirm proposition 2, which suggests that US and EU GM food policies differ in terms of their level of restrictiveness because they are guided by different underlying paradigms.

One of the characteristics of explanatory paradigms is that they are often, although not always, invisible to those who are influenced or guided by them. They are therefore seldom explicitly articulated. Consequently, my choice of paradigms in this chapter has been the fruit of a process, the culmination of collecting and analyzing primary and secondary sources, including policy documents, secondary literature, and interviews. My aim in analyzing empirical data was the identification of paradigms that were comprehensive enough to be inclusive, and still specific enough to provide useful explanations for GM food policy.

In the course of my research, I came to the conclusion that two pairs of paradigms are fundamental to explaining GM food policies in the US and the EU: US GM food policy is relatively permissive because it is guided by the "economic competitiveness" and "sound science" paradigms. EU policy, on the other hand, is relatively restrictive because its policies are based on "environmental and health protection" and "precautionary principle" paradigms.

The paradigms in question can also be seen as components of more general paradigms or worldviews. The dominant worldview in technologically advanced societies is often referred to as the "industrial" worldview, which is often contrasted with an alternative "post-industrial", "environmental" or "ecological" worldview. In the field of GM foods, the dominant paradigms in the US may be seen as components of the industrial worldview while the dominant paradigms in the EU can be understood as part of the post-industrial,

${ }^{130}$ Chapter 6 builds on an article on the role of paradigms in the GM food policy debate (Ramjoué 2003). 
environmental worldview. To the extent that the adoption of the dominant paradigms in the EU has been more recent than in the US and subsequent to the rDNA debate, it can be argued that the EU has experienced a significant paradigm shift where genetic engineering is concerned, whereas a paradigm shift has not occurred in the US.

The extent to which other policy areas in the US and the EU are dominated by paradigms that reflect opposing worldviews is a subject of great interest but beyond the scope of this study, which concentrates on a specific policy area.

\subsection{Economic competitiveness versus environmental and health protection}

\section{US and EU paradigms described}

US policy on GM food and other applications of biotechnology has been devised against the backdrop of the larger goal of achieving and maintaining economic growth and international competitiveness. Industry in general and the biotechnology industry in particular are seen as motors of the US economy, and the role of policy is hence to create a secure and predictable regulatory environment that will make it possible for industry to operate efficiently and productively. Connected with this competitiveness paradigm is a model of agricultural growth based on industrial methods (so-called "agribusiness" ${ }^{131}$ ). This agricultural growth model in turn is intimately linked with geography and the economic importance of agricultural exports for the US economy.

Although EU policy emphasizes the need to strike a balance between competitiveness through and protection from biotechnology, the latter goal prevails in the case of GM food. The EU's policy in this area is guided by the paradigm that consumer health and the environment should be protected from any potential harm from GM foods. As a result, EU policies are relatively restrictive, imposing regulations on the biotechnology industry that may hinder economic

131 “Agribusiness" refers to large-scale and capital-intensive agricultural business practices and models. 
competitiveness for the sake of upholding strong environmental and health protective measures. The EU's recent attempt to move away from intensive farming to more sustainable forms of agriculture further accentuates the protective EU paradigm. ${ }^{132}$

It is crucial to emphasize that the described paradigms are an expression of US and EU priorities, not an exclusive focus. Both the EU and the US view biotechnology as contributing to economic competitiveness, and both aim to protect their citizens' health and the environment. However, the EU and US set different priorities and give these elements varying degrees of importance. A search for balance is especially noteworthy in European Union policy documents, which clearly refer to science and technology as driving forces of the economy, but privilege protective and precautionary aspects. The US also strives for balance: while prioritizing economic growth and competitiveness, it also attempts to protect the environment and consumer health, though as a subordinated goal. The strength of the economic competitiveness paradigm is "invisible" in the sense that US policy makers do not necessarily think that they are subordinating other policy goals to economic competitiveness. They consider their level of protection of the environment and health to be adequate.

The weight given to one or another paradigm in a public debate is of great importance and is influenced by the impact of actors and actor coalitions. This topic will be dealt with in Chapter 7.

\section{Paradigm manifestations}

The described paradigms appear in primary GM food policy documents, and are discussed in secondary literature, either overtly or implicitly. In its 1984 "Proposal for a Coordinated Framework", the White House's Office of Science and Technology Policy (OSTP) underlined the Congressional Office of Technology Assessment's recent finding that "[a]lthough the United States is currently the world leader in [..] commercial development of new

${ }^{132}$ Intensive farming or agriculture is an agricultural production system seeking to maximize production, using methods such as monoculture, and tools such as chemical pesticides. Sustainable refers to a method of using a resource so that it is not depleted or permanently damaged. Sustainable agriculture aims to farm in a manner that is efficient and productive while conserving and improving the environment and local communities. 
biotechnology, continuation of the initial preeminence of American companies [...] is not assured" (Office of Science and Technology Policy 1984: 50857). Accordingly, OSTP emphasized that the "tremendous potential of biotechnology to contribute to the nation's economy [...] makes it imperative that [its] progress [...] be encouraged" (Office of Science and Technology Policy 1984: 50856).

Confirming the goals of the 1984 Proposal, the 1986 Coordinated Framework sought "to achieve a balance between regulation adequate to ensure health and environmental safety while maintaining sufficient regulatory flexibility to avoid impeding the growth of an infant industry" (Office of Science and Technology Policy 1986: 23302-3). Further analysis suggests an emphasis on achieving and increasing economic growth and international competitiveness as the greater goal, and a subordination of the goal of protecting the environment and public health. In line with the product-based approach, explained in Chapter 3, the Coordinated Framework established that existing laws would be applied to GM food. This decision was justified by the statement that

"existing health and safety laws [have] the advantage that they [can] provide more immediate regulatory protection and certainty for the industry than [would be] possible with the implementation of new legislation" (Office of Science and Technology Policy 1986: 23303).

In any case, "[a]ny approach to implementing guidelines should not impede future developments in rDNA technology" (Office of Science and Technology Policy 1986: 13308). This language indicates that US priorities at that time lay in providing a reliable and efficient regulatory environment for the biotechnology industry to produce and commercialize GM products in order to promote US economic growth and competitiveness.

A further element connected to the competitiveness paradigm and raised by a number of interviewees is that the first commercially successful applications of agricultural biotechnology were developed in the United States, and not in Europe, ${ }^{133}$ and that this fact can help explain why US policy is more supportive

133 It should be noted, however, that the methods underlying agricultural biotechnology applications were not developed only by industry, nor were they exclusively the result of work done in the United States. As recounted by Charles, modern agricultural biotechnology applications resulted from the work done in parallel at several research institutions, in particular the Washington University of St. Louis in the US (Mary-Dell Chilton), the University of Ghent in 
of these applications than EU policy. Margaret Mellon of the Union of Concerned Scientists (UCS), a US-based non-governmental organization critical of agricultural biotechnology ${ }^{134}$, captures the essence of this argument:

"this technology is our baby; you regard your own offspring much more tenderly than someone else's. [...] The reverse situation would have been interesting to watch: what would have happened if it had been European companies to develop the technology and bring it to the US?" (interview with Margaret Mellon, Union of Concerned Scientists, 9 June 2004, Washington, DC).

In this context, it is also worth mentioning that Europe's negative reaction to GM products can be viewed as being motivated by a wider negative sentiment towards the paradigm of economic competitiveness itself, a sentiment that manifests itself in a suspicion of large multinational corporations and American hegemony. This attitude reflects the European sociopolical context of the late 1990s and at the beginning of the new millennium, characterized by the uncertainties that come hand and hand with globalization. As Geert Ritsema and Carmen Olmedo of Friends of the Earth Europe put it, "in Europe, there is a stronger suspicion than in the US regarding corporations and corporate influence" (interview with Geert Ritsema and Carmen Olmedo, Friends of the Earth Europe, 3 September 2004, Brussels). According to the personal views of another interviewee who preferred not to be identified,

"the anti-GM movement [in Europe] seems not to be motivated only by opposition to a particular technology. It is delivered too passionately to be just that. It is motivated to some extent by anti-globalization, anti anti-big business sentiment, anti-industrialization of food production, and so on."

Similarly, Mellon suggests that "European GM crop and food critics feed not off fear of risk, but off fear of hegemony and resentment of American power." (interview with Margaret Mellon, Union of Concerned Scientists, 9 June 2004, Washington, DC).

Belgium (Jozef Schell and Prof. Marc Van Montagu), and at Monsanto (Rob Horsch) (Charles 2001).

${ }^{134}$ Despite its name, the Union of Concerned Scientists (UCS) is not a scientists' association, although some of its members are scientists. It is a non-governmental not-for-profit organization open to all citizens that are concerned about environmental issues. Further information on UCS is provided in Chapter 7. 
The economic competitiveness paradigm underlying US GM food policy and biotechnology policy more generally has persisted into the 1990s and up to the present day. In 1990, former US President George H.W. Bush's “Principles of regulatory review" (reproduced as annex 1 of Office of Science and Technology Policy 1992) stated that "all regulation in environmental and health areas [...] should use performance standards [setting goals to be achieved] rather than specifying rigid controls or specific designs [specifying means of achieving results] for compliance" in order to encourage the development of modern products by methods that are less costly and effective than traditional methods.

The US agencies implementing the Coordinated Framework of 1986 have adhered to the economic competitiveness paradigm in more or less explicit ways. FDA is the most vocal of the US agencies in its implementation of the economic competitiveness paradigm. One of the goals expressly stated in FDA's 1992 document on "Foods Derived From New Plant Varieties" is "to ensure that relevant scientific, safety, and regulatory issues are resolved prior to the introduction [ ... of GM foods] into the marketplace" (Food and Drug Administration 1992: 22984). This goal illustrates that health and environmental security issues are taken seriously, but that they are viewed as conditions for entering the market. This accentuates the primacy of the market economy, and emphasizes that the main priority is to adapt regulation to industry's needs.

APHIS and EPA are less openly concerned with economic issues, as their mandates are to oversee agriculture and the environment respectively. However, they too operate within the economic competitiveness paradigm. An illustrative example was given by Stephen Johnson, Assistant Administrator of EPA's Office of Prevention, Pesticides, and Toxic Substances in 2003 when he testified to the US Congress that "EPA had been working with companies and individuals since the early $1980 \mathrm{~s}$ in developing a regulatory approach for pesticide-related biotechnology products" (US Congress, House of Representatives 2003a, my emphasis). The fact that an agency would characterize the policy process as one of "working with companies" indicates that support for the biotechnology industry is a key element of EPA's main mission of protecting the environment. 
A detailed look at EU GM food policy reveals a serious attempt to achieve a balance between the goals of competitiveness through biotechnology and protection from biotechnology. Current article 95 of the Treaty establishing the European Community (consolidated text, 2002), which forms the legal basis for former Council Directive 90/220 and current EP and Council Directive 2001/18 (revised Directive 90/220), deals with the approximation of laws ${ }^{135}$ in the context of EU internal market provisions. While its goal of implementing the internal market is mainly economic in character and therefore stresses primarily economic goals, it also mandates "a high level of protection" of the environment and consumer health. EU lawyer Christoforou summarizes this search for balance in the EU's GM food policy by emphasizing that the EU seeks to balance consumers' and the biotechnology industry's interests while trying to foster consumers' confidence in the regulatory process" (Christoforou 2004: 708-9).

Despite this search for balance, EU policy documents put a decidedly stronger emphasis on the need to protect health and the environment than on economic competitiveness. While directives and regulations on GMOs and GM foods mention the need for harmonization and strengthening of the internal market, they more frequently and forcefully mention the need to protect from GMOs than to grow economically through them. Moreover, the emphasis on the need for environmental and health protection has increased with the passage of the Directive 2001/18 on deliberate release of GMOs (European Parliament/Council of the European Union 2001), food and Regulations 1829/2003 and 1830/2003 on food and feed (European Parliament / Council of the European Union 2003a, 2003b).

Council Directive 90/220 (Council of the European Union 1990b), negotiated during the mid to late 1980s and adopted in 1990, was the first comprehensive EU directive on the deliberate release of GMOs into the environment. Its first article states two policy goals. The first is to harmonize legislation, which is explained by the EU's more general objective of integration and contains a commitment to economic competitiveness by furthering the EU's internal market. The second goal is "to protect human health and the environment" (Council Directive 90/220, art. 1.1). These two goals are

135 "Approximation of laws" refers to the aligning of national laws to be coherent with EU law. 
unchanged in EP and Council Directive 2001/18, but explicitly refer to the precautionary principle (see discussion of the precautionary principle paradigm below), an illustration of the trend towards increasing restrictiveness in the EU's GM food and crop policies. Furthermore, both directives must ensure "that all appropriate measures are taken to avoid adverse effects on human health and the environment [...]" (art. 4.1 in both Directives). The repeated use of this type of language is indicative of an underlying environmental protection paradigm.

Evidence of the protection paradigm can also be found in regulations specifically regarding GM foods. EP and Council Regulation 258/97 (European Parliament/Council of the European Union 1997), now replaced by EP and Council Regulation 1929/2003, showed a relatively strong commitment to economic competitiveness through a functioning internal market, but established that GM foods must not present a danger for or mislead the consumer (art. 3). Regulation 1829/2003 reflects the recent emphasis on the environment and health protection paradigm by inserting the explicit objective of "ensuring a high level of protection for human life and health, animal health and welfare, [and] environmental and consumer interests [...] (art.1.a).

\section{Linking competitiveness and protection to agriculture}

The US's emphasis on economic competitiveness and the EU's focus on environmental and public health protection are to some extent reflected in different US and EU models of agricultural growth and "agri-environmental" reform trends. The dominant US agricultural model, often referred to as “agribusiness", privileges agricultural industrialization, standardization and cost reduction in order to increase profits from agriculture. In the US, agrienvironmental reform, that is the use of environmentally sustainable agricultural methods, has always been subordinated to the agribusiness model which has a "less public, more managerial approach to agri-environmental issues [...] (Potter 1998: 161). Within this model, GM crops can represent a useful technological innovation tool for agribusiness, and this helps explain why US policy encourages their use through relatively permissive policies.

The EU, which like the US has used intensive or "agribusiness" farming methods for many decades, has recently attempted to move away from this model 
of agricultural growth in a more decided way than the US. At least at the level of political rhetoric, it currently emphasizes the ideal of sustainable agricultural growth, and suggests goals such as taking intensively cultivated farmland out of production and focusing on maintaining or reestablishing biodiversity. In the context of this new trend, the EU has little incentive to embrace GM crops and foods, which are associated with intensive farming practices by the EU public. In connection with public sentiment and with the new European ideal of environmentally sustainable agriculture, the EU is more inclined to take a protective and thus restrictive stance towards the environment in its GM food and crop policies.

As in the case of the general economic growth and protection paradigms, it is important to stress that US and EU agricultural growth models are different in relative terms, and that they have similarities as well as differences. Since World War II, both US and EU agricultural policies have pursued the objectives of "feeding a population", "self-sufficiency" and achieving a sense of “community" (Richardson 2000: 78, see also Ingersent/Rayner 1999). In order to reach these objectives, both the US and EU farming sectors have widely used intensive farming methods widely.

It should be noted here that the food shortages accompanying World War II in Europe had a profound impact on the development of postwar agricultural policy in Europe. There was a conviction among policy-makers that Europe should be able to feed itself and should be self-sufficient in basic food production even if certain foods could be produced more cheaply in other countries, such as the US or Canada, particularly suited to cost-effective production of grains. The European Economic Community (EEC), later followed by the EC and the EU, therefore followed an agricultural policy in which cost issues were balanced against a wide range of other social and historical considerations. The US, which often accuses the EU of protectionism in the area of trade, is insufficiently aware of the importance of these issues in shaping policies in Europe.

The EU and the US began to recognize the need for agri-environmental reform in the late 1970s (Potter 1998, Richardson 2000). In the United States, this realization resulted in the innovative Conservation Title of the 1985 Farm Act, which focused mainly on subsidizing farmers engaging in soil conservation and 
was hailed as a "magic bullet" that could "save soil, cut production, and support farmers' incomes" (Potter 1998: 61). The problem with its co-called Conservation Reserve Program (CRP) was the wide degree of discretion that it granted during the implementation phase. In essence, it was seen by many to be a farmer subsidy scheme rather than a soil conservation program (Potter 1998: 70 et seq.). The 1990 Food, Agriculture, Conservation and Trade Act achieved a broadening of agri-environmental goals from soil conservation to irrigation, reforestation and other environmental issues, but the mid-1990s brought agricultural policy's focus back onto soil and production. As Conservation Reserve Program contracts expired, a significant proportion of CPR land was returned to production (Potter 1998: 78). The 1990s trend towards increasing world trade liberalization brought about the Federal Agricultural Improvement and Reform Act of 1996, which decoupled the level of subsidies from the level of from production, thus introducing a "flexibility that encouraged area shifts towards crops where yield-improving GMOs were entering commercial use" (mainly corn and soybeans) (Haniotis 2001: 172). This trend was reversed in 2002 by the Farm Security and Rural Investment Act, which once again coupled subsidies to production, but also increased expenditure for environmental protection.

As this snapshot of American farm and agri-environmental policy shows, environmental goals were never central to agricultural policy reform, but merely a by-product. Even the 1985 Conservation Title, which was viewed at the time as being revolutionary, in the end subordinated conservation to income maintenance (Potter 1998: 156).

In the EU, agri-environmental reform was announced some years later than in the US as part of the 1992 reforms of the EU's Common Agricultural Policy (CAP). The overall goal of CAP reform was to make agriculture more sensitive to market forces by decoupling subsidies from production levels and thus decreasing output. The 1992 reform contained a series of measures encouraging environmentally friendly agriculture including farming practices reducing pollution, environmentally friendly land use and management, and the setting aside of agricultural land (Bruckmeier/Wiking 2002: 15). The underlying idea was to recognize "farmers as potential producers of the countryside" and to 
subsidize "them for the environmental services they provided" (Potter 1998: 156).

According to the authors of the 1992 reform, it represented no less than a "renegotiation of the social contract between farmers and the state" (Potter 1998: 156). However, the implementation of these reforms has produced mixed results. A positive result in agri-environmental terms is that, in terms of rhetoric, "EU emphasis is [now] not on increased quantity, but on enhanced quality" (Haniotis 2001: 173). On the downside, “[...] there is still no breakthrough in the conversion of intensified agriculture" and "no clear and coherent trend towards sustainable development in the near future" (Bruckmeier/Wiking 2002: 40, 42). Despite this mixed result, it can be concluded that on balance, the EU's attempts to pursue environmentally friendly agricultural policies have been more consistent and somewhat more successful than has been the case in the United States.

Most importantly, in Europe, the ideal of reinforcing sustainable farming and of linking agricultural and environmental policies, has gained popularity over the last decade or so. Europeans increasingly appear to care about the process of agricultural production, just like they care about the process of production of food. Karin Ricker adds to this consideration the personal opinion that

"Europeans are willing to make personal sacrifices for the environment. I believe Americans would object to this, because it goes against the concept of pursuit of personal happiness and freedom" (interview with Karin Ricker and Edmundo Garcia, Jr., Food and Drug Administration, 10 June 2004, Washington, DC). ${ }^{136}$

Hayden Milberg of the National Corn Growers Association (NCGA) further explains that

"US and EU citizens have two different viewpoints on what agriculture is, and how it can and should serve the greater public good. There is a perspective in the United States that farming is primarily for food production, whereas the European view of farming is more complex,

\footnotetext{
${ }^{136}$ Ricker emphasizes that this is a personal opinion in no way connected with official FDA positions.
} 
including other social benefits that are not quantifiable" (interview with Hayden Milberg, NCGA, 9 June 2004, Washington, DC).

These comments reflect different conceptions of the "social contract" or balance of rights and obligations that should exist between the state and its citizens. In general terms, Europeans are willing to make sacrifices for the good of society as a whole in exchange for public support in areas such as health services, welfare, employment, education, etc. In comparison, Americans are less apt to request less social protection and support from the state, but they expect individual freedom and economic opportunity.

A further element to mention are Europeans' and US Americans' different perceptions of what food and food quality means (Echols 1998). Food in the US is primarily seen as a commodity that must be safe and nutritious. Jeffrey Barach of the Food Products Association (FPA) suggests that

"sometimes Americans look at food as just fuel - "just fill the tank and go on with the next event', whereas Europeans maybe have more of an interest in the many social aspects of food [...]. Not that Americans don't, but it seems to be more of a priority all the time for Europeans [...]" (interview with Jeffrey Barach, Food Products Association, former National Food Processors Association, 15 June 2004, Washington, DC).

Indeed, while nutrition and safety are important aspects for Europeans, too, quality has a wider-ranging meaning for them. Food is an expression of culture and tradition in Europe. Thus, Europeans seek food quality in production methods (e.g. food made following a traditional recipe) or in food originating from a specific region of Europe where its production is traditional. They also value foods that are relatively unprocessed, and foods that have been produced by "natural" or "organic" methods. Specialty wines, cheese, and meats are a few examples of the many products that receive particular attention in these respects.

By extension, in Europe, GM food is perceived as the ultimate result of intensive agriculture and therefore is considered unnatural. It does therefore not qualify as a high quality food. Austrian Member of the European Parliament Karin Scheele suggests that Europeans are not inherently more skeptical of GM 
foods than Americans because of sock events such as the BSE crisis (described in Chapter 2. Instead, "European consumers are more emancipated, environmentally conscious, and aware of the issue of genetic engineering than Americans" (interview with Karin Scheele and Sigrid Semlitsch, European Parliament, 7 September 2004, Brussels. In summary, as one observer notes, GMOs “challenge traditional European ideas about food" (Richardson 2000: 81). ${ }^{137}$

To a certain extent, different agricultural growth models are also the result of structural and economic factors that transcend politics. Geography is one of these factors. The area of arable land is far greater and more continuous in the United States than is the case in countries of the European Union. Hayden Milberg of the NCGA observes that

"the US and Europe have different scales of production. You can see it in the size of farm machinery: farm machinery in the United States is large in comparison with European equipment because of different farm and plot sizes" (interview with Hayden Milberg, NCGA, 9 June 2004, Washington, DC).

The wide, flat expanses of land in the American Midwest are well-suited for large farms and intensive cultivation of crops such as corn, soybeans and wheat, and are far away from main US cities. There are clear geographical divisions between the part of the US that is farmed, and the urban centers and suburbs, where most US Americans live. As one Margaret Mellon of the Union of Concerned Scientists summarizes the situation,

"In the US, most people live on the two coasts, and agriculture is somewhere else. People don't see it, so when you talk about risks, they are not in anybody's back yard" (interview with Margaret Mellon, Union of Concerned Scientists, 9 June 2004, Washington, DC).

US soybean and corn producing states are Illinois, Indiana, Iowa, Kansas Minnesota, Missouri, Nebraska, Ohio, and South Dakota. Cotton is grown in the South and West of the US, for example in Georgia, Mississippi, Tennessee,

${ }^{137}$ Some actors within the GM food debate do not share this point of view. For example, Friends of the Earth Europe maintains that "US citizens care about their food just as much as Europeans. The main difference is that they don't know about GMOs" (interview with Geert Ritsema and Carmen Olmedo, Friends of the Earth Europe, 3 September 2004, Brussels). 
Texas, and California, and in some Midwestern states such as Kansas and Missouri.

European farms, on the other hand, are more numerous, on average smaller (Richardson 2000: 78), and less concentrated in specific areas. Roxane Feller of the Committee of Professional Agricultural Organisations in the European Union and General Confederation of Agricultural Co-operatives in the European Union (COPA-COGECA) notes that

"In contrast with US agriculture, European agriculture is more familyfarm oriented. We do not have the wide expanses of grain fields that the US does. In Europe, dimensions and approaches are both on a more human scale. Perhaps the European farmer is closer to the consumer than the US farmer and is therefore more aware of his concerns" (interview with Roxane Feller, Committee of Professional Agricultural Organisations in the European Union and General Confederation of Agricultural Co-operatives in the European Union (COPA-COGECA), 14 September 2004, Brussels).

In Europe, main intensive grain-growing farming areas are found in the Eastern part of England, Northern France, and in parts of Belgium, Germany, Denmark and Spain. Main producers of crops including wheat and corn are France, Germany, the UK, and Spain. Very few soybeans are grown in Europe.

As a result, in the US, land to be used for agriculture and land to be protected by environmental policies are conceptually divided. In Europe, such a division is impossible in most farming areas, which are a heterogeneous mixture of farmland, areas protected for conservation, towns and recreational areas. Moreover, population density is generally much higher in EU farming areas than is the case in the US since they are closer to towns and cities. According to Levidow,

"[a]lthough European agriculture also uses chemical-intensive methods, it is widely regarded as an integral part of the environment, i.e. as an aesthetic landscape, an element of local heritage, and wildlife habitat [...] U.S. farms are seen as analogous to factories and are sharply demarcated from wilderness and nature conservation areas. "(Levidow 1999b: 20). 
The US's relative preference for the "agribusiness" model should also be seen within the wider context of trade. Revenue from corn and soybean trade is much more important for the US than for the EU. The US produces and exports far more corn and soybeans (GM and non-GM varieties) than the EU. In 2004, the US produced 298 million metric tons of corn and 85 million metric tons of soybeans while the EU produced 53 million metric tons and 0.8 million tons respectively (Food and Agriculture Organization FAOSTAT database). On average, over the past decade, the US exported one quarter to one third of its corn and 30 to $40 \%$ of its soybeans (US Department of Agriculture, Foreign Agricultural Service Statistics for Bulk, Intermediate, and Consumer Oriented). Its revenue from export of bulk commodities such as corn and soybeans to the EU is considerable. Within this context, and given the geographical features of the American Midwest, it makes sense from a purely economic standpoint for the US to use GM crop varieties: the US experienced "a strong supply push that encouraged [its] development of agricultural biotechnology" (Haniotis 2001: 173).

However, the increased use of GM seed varieties from the mid-1990s onwards did not taken into account the negative reaction of the European public. The blow that US exports of corn and soybeans to Europe has suffered over the past years as a result is an indication of how important agricultural exports to Europe are for the US (see Table 14). Before the facto moratorium came into effect in $1999,4.7 \%$ of US corn exports and $32 \%$ of US soybeans went to the EU. In 1999 , these numbers had sunken to $0.3 \%$ and $22.8 \%$ respectively and have remained low since. The lifting of the moratorium in 2004 is not yet reflected in trade figures, and might not be for some time in the light of remaining Member State disagreements over GM foods. For the US, this reduction in export volume has meant a considerable cut in revenue from trade. Its revenue from corn sales to the EU has been reduced from over US\$392 million in 1996 to just under US\$9 million in 2004. Soybean sales to the EU have gone from over US\$2.3 billion in 1996 to about US\$863 million in 2004. EU revenue from export of corn and soybeans to the US is negligible in comparison (well under US\$100,000 most years for both corn and soybeans, as of 1996).

In conclusion, revenue from trade, in particular from crops such as corn and soybeans are of great importance for the US. As a result, "US policies tend to 
be [...] supply-driven" and "encourage production flexibility and export" (Haniotis 2000: 84). This is one part of the explanation for permissive US policies regarding GM crops.

Table 14: US corn and soybean production, total exports, exports to the EU

\begin{tabular}{|c|c|c|c|}
\hline & & Corn & Soybeans \\
\hline \multirow[t]{6}{*}{1996} & Production & $\$ 25,250,000,000$ & $\$ 17,490,000,000$ \\
\hline & Total exports 1996 & $\$ 8,404,170,000$ & $\$ 7,324,455,000$ \\
\hline & & (33.3\% of production) & ( $41.9 \%$ of production) \\
\hline & Exports to the EU & $\$ 392,672,000$ & $\$ 2,340,311,000$ \\
\hline & & (4.7\% of exports; & (32.0\% of exports; \\
\hline & & $1.5 \%$ of production) & $13.4 \%$ of production) \\
\hline \multirow[t]{6}{*}{1999} & Production & $\$ 17,100,000,000$ & $\$ 12,290,000,000$ \\
\hline & Total exports & $\$ 4,924,202,000$ & $\$ 4,531,580,000$ \\
\hline & & ( $28 \%$ of production) & (36.9\% of production) \\
\hline & Exports to the EU & $\$ 15,053,000$ & $\$ 1,032,860,000$ \\
\hline & & ( $0.3 \%$ of exports; & (22.8\% of exports \\
\hline & & $0.09 \%$ of production) & $8.4 \%$ of production) \\
\hline \multirow[t]{6}{*}{2004} & Production & $\$ 23,020,000,000$ & $\$ 17,750,000,000$ \\
\hline & Total exports & $\$ 5,740,716,000$ & $\$ 6,672,115,000$ \\
\hline & & ( $24.9 \%$ of production) & (37.6\% of production) \\
\hline & Exports to the EU & $\$ 8,945,000$ & $\$ 863,121,000$ \\
\hline & & ( $0.2 \%$ of exports; & (12.9\% of exports; \\
\hline & & $0.04 \%$ of total production) & $4.9 \%$ of production) \\
\hline
\end{tabular}

Source: (US Department of Agriculture, Foreign Agricultural Service. Statistics for Bulk, Intermediate, and Consumer Oriented)

Note: All figures are in US\$ and based on the European Union of 15 EU Member States before enlargement to 25 Members in 2004.

\subsection{Sound science versus precautionary principle}

\section{US and EU paradigms described}

A second fundamental paradigm difference lies in US and EU perceptions of the capacity of science to deal with uncertainty, and, by extension, in how potential risks connected with GM foods are defined and addressed.

The United States bases its GM food policy on the so-called "sound science principle" or "science-based approach", a strong and unwavering faith in science's capacity to furnish unequivocal information and establish clear answers. 
This in turn supposes that science and scientific expertise can and do deliver the uncontestable evidence necessary to make sound policy decisions. In the case of agricultural biotechnology, this principle has led to regulators' perceived certainty that GM foods do not pose significant risks, and that a narrow definition of risks connected to GM foods is acceptable. It is supposed that GM foods pose no significant risk until proven otherwise, for example by consumers or by a demonstrated impact on the environment. This approach makes a relatively permissive GM food policy possible.

The European Union also abides by the sound science principle, but introduces an important caveat by also basing its GM food policy on the precautionary principle. The idea behind this is that "sound science" as a principle alone may not always suffice, and that scientific certainty may not always be achievable. The precautionary principle states that lack of scientific information and certainty shall not stop measures from being taken to prevent potential hazards. The EU views the area of GM foods as one of scientific uncertainty, and therefore assumes that GM products may be hazardous until proven safe. As will be explained more fully below, this in turn is connected with the fact that the definition of potential risks attributed to GM foods is fairly wide. A relatively restrictive GM food policy is necessary to conform to this paradigm.

Empirical evidence suggests that the "sound science" and "precautionary principle" paradigms are not mutually exclusive. Indeed, in the case of GM food, both the US and the EU believe in the power of science to furnish a sound basis for policy-making, and both also emphasize the need for precaution where appropriate. The US, however, shows a strong tendency to accept the current level of information on potential risks as adequate, while the EU is not satisfied by the available body of knowledge and thus mandates a precautionary approach until further scientific information becomes available.

\section{Paradigm manifestations}

The US's sound science paradigm can be illustrated by policy documents on GM foods from the beginning of regulation in this area until today. In 1984, OSTP attributed the US's leadership in the area of biotechnology to "a strong science base" and underlined the goal of creating a regulatory process "based on 
the best available scientific facts [...]" (Office of Science and Technology Policy 1984: 50856-7). In the 1986 Coordinated Framework, OSTP ruled out processbased regulation, affirming that "there is no scientific basis for specific legislation for the implementation of rDNA technology and applications" (Office of Science and Technology Policy 1986: 23308). This kind of language reveals the perception that "best science" and "scientific facts" are indeed available to furnish necessary information and answers to policy-makers.

Policy based on this principle can be understood as "a means of asserting that science alone, not politics or values, [is] the basis of setting policy" (Krimsky/Murphy 2001: 5). Moreover, this "belief in the rationality of science" leads to science being "used as an important instrument for legitimating government decisions" (König 2002: 73). Skeptics of the approach note that the result may be "junk science", which aims "to protect and defend strongly held values, [while] the arguments are cast in the guise of scientific debate (Sundlof 2000: 139). Similarly, Krimsky and Murphy suggest that US regulatory agencies use the sound science principle to make "discretionary choices" (Krimsky/Murphy 2001: 39).

After the US's initial biotechnology policy had been developed in the early 1980s, the sound science principle and reliance on scientific expertise was reiterated on many occasions. For example, the White House endeavored to reinforce "the strength of science-based regulation" in a press release in 2000 regarding a series of recent food and agricultural biotechnology initiatives:

"The US regulatory approach to agricultural biotechnology applies principles of sound science to ensure that there are no unacceptable human health and environmental risks. This system [...] has resulted in rigorous scientific review of products, while providing a predictable regulatory environment that fosters scientific advancement and product innovation" (White House 2000).

Also in 2000, in a speech entitled "making good on biotechnology's global potential" and focusing on food safety, Undersecretary of State Alan Larson not only emphasized that the US food safety system is based on sound science, but also wished for the worldwide adoption of this model. He particularly deplored the "particular struggle in Europe", marked by "undue and 
unscientific fears of new technology and a paralysis in science-based food safety approvals and regulations". He further stated that "[d]espite early positive efforts by some European authorities, political parties and governments now invoke the so-called 'precautionary principle' to justify decisions that have no scientific foundation" (Larson 2000). This type of rhetoric suggests the conviction that the US's sound science principle is the best regulatory approach, and that any diversion from it is irrational.

As suggested above, the EU's policies are also based on sound science. However, the EU tries harder than the US to achieve a balance, in this case between the goal of achieving an acceptable level of scientific certainty and the need to deal with scientific uncertainty. In summary, the EU is dedicated to "creating a science-based and comprehensive regulatory framework based on the precautionary principle" (Christoforou 2004: 708-9). According to Christoforou, this potentially contradictory goal is partly connected to new doubt regarding the sound science paradigm: "the positivist view of science, considering it to be a powerful and neutral tool capable of predicting risk and causality [...], seems to be no longer valid" (Christoforou 2004: 686). As will be discussed below, the GM food debate in Europe goes beyond narrow risk considerations to include social, cultural and ethical issues. Therefore, the need for non-scientific expertise, for example farmers' expertise, is increasingly valued and trusted (Heller 2002). This trend is not motivated by distrust of science per se. As mentioned earlier, the rise of globalization and the power of multinationals have led to increased suspicion that industry and its supporters inside and outside government may manipulate scientific information for their own benefit.

The German "Vorsorgeprinzip", introduced in Germany's environmental policy in the $1970 \mathrm{~s}$, is habitually identified as the precautionary principle's forerunner (König 2002: 69). Since that time, the precautionary principle has been prescribed, defined and referred to in various forms by several international bodies. It was explicitly recognized in 1992 by the United Nations (UN) Conference on Environment and Development in Rio de Janeiro for the case of environmental policy in a generally accepted definition:

"In order to protect the environment, the precautionary approach shall be widely applied by states according to their capabilities. Where there are 
threats of serious or irreversible damage, lack of full scientific certainty shall not be used as a reason for postponing cost-effective measures to prevent environmental degradation" (United Nations General Assembly 1992: Principle 15).

The idea that precaution and prevention are necessary if scientific evidence is inconclusive has been widely applied at the EU-level, in particular with regard to the environment. It was first introduced at the European Community level by the 1992 Maastricht Treaty (Treaty on European Union). Consequently, the consolidated Treaty establishing the European Community mentions the precautionary principle under its section on EU environmental policy:

"Community policy on the environment shall aim at a high level of protection taking into account the diversity of situations in the various regions of the Community. It shall be based on the precautionary principle and on the principles that preventive action should be taken, that environmental damage should as a priority be rectified at source and that the polluter should pay" (Treaty establishing the European Community, consolidated text, 2002, art. 174.2).

In 2000, the European Commission published guidelines for the principle's application to EU policies. These guidelines stated that in the EU, the precautionary principle can cover those instances

"where scientific evidence is insufficient, inconclusive or uncertain and there are indications through preliminary objective scientific evaluation that there are reasonable grounds for concern [...] (European Commission 2000d: 10).

The precautionary principle entered into GMO and GM food regulation implicitly even before these the Maastricht Treaty of 1992 introduced the concept into the Treaty establishing the European Community. Council Directive 90/220, approved in 1990, mentioned that "Community action relating to the environment should be based on the principle that preventive action should be taken" where 
necessary (Council Dir. 90/220: preamble). ${ }^{138}$ After GM foods and crops entered the commercial phase in the mid-1990s, controversy intensified and led to further emphasis on precautionary aspects of GM food policy (Levidow/Carr/Wield 2000: 189). Rene von Schomberg summarizes this development as follows:

"EU policy on GMOs has become increasingly precautionary from 1990 until today. The original version of Directive 90/220 contained the basis for this precautionary dimension, but focused on direct effects of GMOs, while Directive 2001/18 also addresses indirect and delayed effects, and even can take into account long term effects. This change has occurred because of both public discussion and scientific deliberation on risk over the past years. It has led to new measures in consistency with the precautionary principle being introduced such as mandatory labeling, postmarket monitoring, and traceability" (interview with Rene von Schomberg, European Commission, 2 September 2004, Brussels).

The EU's current policy on GMOs and GM food makes explicit reference to the precautionary principle. EP and Council Directive 2001/18 recalls that under the Treaty on the European Union, "action by the Community relating to the environment should be based on the principle that preventive action should be taken" (preamble 6). Moreover, one of the general obligations of the Directive is that

"Member States shall, in accordance with the precautionary principle, ensure that all appropriate measures are taken to avoid adverse effects on human health and the environment which might arise from the deliberate release or the placing on the market of GMOs" (art. 4.1).

The precautionary principle paradigm has been both praised and criticized. For example, Myhr and Traavik support the precautionary principle by suggesting that the "obvious lack of data and insufficient information calls for the application of the precautionary principle" and that this may "provide the best

${ }^{138}$ Levidow et al. note that as a result of its precautionary approach, "[s]oon after its enactment, [this] directive was [...] attacked as 'irrational' by some industry lobbyists." Therefore, "subsequently, the European Commission redefined environmental goals "in market terms", that is with more of an emphasis on economic growth. According to Levidow et al. this was a sign that the "precautionary potential of Directive 90/220 was coming under pressure". It was much debated by Member States during the implementation phase of Council Directive 90/220 (Levidow et al. 1997: 481, see also Levidow et al. 1996). 
opportunity to narrow uncertainty about health and environmental cause and effects" (Myhr/Traavik 2001: 74). Critics of the precautionary principle such as Morris contend that the precautionary principle, as used by the EU, is "likely to lead to arbitrary restrictions on international trade" and "irrelevant objections by interest groups who "raise unnecessary fears" (Morris 2002: 59). Further criticism comes from Marchant who characterizes the precautionary principle as "a policy and intellectual cul-de-sac" that, because it is ambiguous and arbitrary, does not provide "a legal standard for environmental decision-making" (Marchant 2002: 44). De Sadeleer confirms that the precautionary principle's legal status is extremely vague and malleable, despite widespread reference to it in laws and regulations (de Sadeleer 2001). ${ }^{139}$

Contrary to what is often said and believed, the EU does not apply the precautionary principle to all policy areas as it does to GM foods and crops. Nor is the United States consistently as adverse to precautionary measures as it is in the case of agricultural biotechnology. Calestous Juma underlines that "The current striking differences between EU and US regulation are specific to GMOs. For example, the EU's regulation of pharmaceuticals is more permissive than that of the US" (interview with Calestous Juma, Harvard University, 25 June 2004, Cambridge, MA).

Vogel (2001) and Löfstedt/Vogel (2001) have identified a change over time or an "exchange of regulatory systems" on health and environmental issues (Löfstedt/Vogel 2001: 399 et seq.). They suggest that the EU was less precautionary from the 1960 s to the 1980 s than it is today, and that the US was more precautionary during that period than it is today. The main reason for this finding is "the emergence of a new European approach toward risk regulation" (Vogel 2001: 18) resulting from the rise of a risk averse and public healthoriented civic culture, the growing regulatory role of the EU, and a series of regulatory failures such as BSE.

Wiener and Rogers (2002) investigate a broader sample of policy areas and find that the EU appears to be more precautionary than the US in some cases (e.g. GMOs, hormones in beef, toxic substances, climate change, guns,

${ }^{139}$ On the wide range of possible interpretations of the precautionary principle, see Sunstein 2004, as well as Dratwa (2002), who describes the different "understandings, claims and hopes" present within the European Commission itself with respect to the principle. 
antitrust/competition policy), whereas the US seems more precautionary than the EU in others (e.g. pharmaceuticals, nuclear energy, lead in gasoline, highway safety, teenage drinking, cigarette smoking, missile defense) (Wiener/Rogers 2002: 322-323). They conclude that: "neither the US nor the EU is a more precautionary actor across the board, today or in the past. Relative precaution appears to depend more on the particular risk than on the country or the era." (Wiener/Rogers 2002: 323). Sunstein agrees with Wiener and Rogers, making the larger point that "the operation of the Precautionary Principle is inextricably intertwined with social risk perceptions" (Sunstein 2004: 3).

It can also be argued that the extent to which the precautionary principle is applied may depend on how it interacts with other paradigms such as the economic competitiveness paradigm. In the case of biotechnology in the US, a precautionary approach definitely took second place to encouragement for a new and promising industry with great export potential. In the EU the economic consequences of applying a precautionary approach were probably considered as less significant.

\section{Linking sound science and the precautionary principle to risks}

The potential risks associated with GM food and crops are what Giddens would term "manufactured risks", since they are the product of human activity (Giddens 1999). Beck, a sociologist like Giddens, views the concept of risk as a systematic way of dealing with hazards and insecurities resulting from modernization (Beck 1986). Based on the sound science principle and the precautionary principle, the US and the EU have found very different ways of dealing with such manufactured risks. These are reflected in US and EU definitions of the potential risks connected with GM foods, as well as in risk assessment requirements and possibilities for exemptions within the authorization process.

Risk definitions The US and the EU define the potential risks attached to GM foods and crops in very different ways. In the US, the potential risks posed by GM foods are precisely defined in terms of their specific characteristics and immediate impacts on human health and the environment. The definition of risk used by US agencies is relatively narrow, specific, direct and short-term. 
This narrow risk definition connected to GM food has its origins in the 1970s debate on regulation of rDNA discussed in Chapter 5. After the development of rDNA techniques in 1973, the initial debate took into account social and ethical aspects in addition to health and environmental concerns. At the 1975 Asilomar conference, however, influential scientists such as Paul Berg and James Watson pushed for a limited definition of potential risks in order to keep the topic of rDNA research manageable, and make a consensus among scientists possible.

In US regulators' minds, by the time the Coordinated Framework was developed in the early 1980s, enough experience had been gained for the validity of this limited risk definition-approach to be confirmed. US President Reagan's emphasis on economic competitiveness and on limiting the introduction of new laws at that time offered further support. M.E. Jones even suggests that "the need to preserve American competitiveness was so important [in the US government's perception] that unproven hazards were downplayed because benefits to the economy were so great" (Jones, M.E. 1999: 262).

The Office of Science and Technology Policy's 1984 proposal for the Coordinated Framework signaled that a narrow risk definition would be used for the evaluation of biotechnology hazards. Referring to the product-based approach, OSTP stated that each review agency would develop "product review criteria and procedures which [were] consistent with its historical experience and scientific data bases from reviewing other products with similar uses" (Office of Science and Technology Policy 1984: 50858). The 1986 Coordinated Framework confirmed this approach. It acknowledged that concerns had been raised "as to whether products resulting from the recently developed techniques would pose greater risks than those achieved through traditional manipulation techniques" (Office of Science and Technology Policy 1986: 23302). By concluding that existing laws "would address regulatory needs adequately", it implicitly reiterated the view that potential risks from GM foods and crops were of a limited nature (Office of Science and Technology Policy 1968: 23303). Krimsky calls this limited risk approach the "simple model", in which

"familiarity with the parental plant and the well-characterization of a gene whose protein product is not known to be harmful to animals or humans 
would qualify the GM crops as safe for human consumption" (Krimsky 2000: 231).

In 1992, OSTP further specified the US regulatory "risk-based"-approach towards GM foods and crops in a policy document on "planned introductions of biotechnology products into the environment". This document stated that the "oversight of planned introductions of biotechnology products into the environment [should be exercised] only upon evidence that the risk posed by the introduction is unreasonable". According to OSTP, a risk is unreasonable "where the full value of the reduction in risk [...] exceeds the full cost of the oversight measure". More specifically, according to OSTP, risk is "a function of the characteristics of the organisms or other products, the particular application [...], and the environment itself" (Office of Science and Technology Policy 1992). ${ }^{140}$ In accordance with this narrow risk definition, federal agencies such as FDA do not expect GM foods to pose significant risks (Food and Drug Administration 1992: 22986). Under potential "unexpected effects" "that may require evaluation to assure food safety", FDA lists precise and immediate risks including the introduction of toxicants or new substances, the alteration of nutrients, as well as allergenicity (Food and Drug Administration 1992: 22987).

The EU defines potential risks more broadly than the US, and includes delayed effects on health and the environment, as well as social and ethical issues. In contrast to the US, in the EU it is "generally accepted that defining the level of acceptable risk is a normative decision that belongs to the democratically elected and accountable institutions of a state" (Christoforou 2004: 702). This decision can therefore not always be precisely determined through "sound science". It is telling that "[...] although the acceptable level of risk can be defined both in qualitative and quantitative terms, in the [European Union] it is practically never expressed in a precise quantitative manner, such as one-in-amillion risk of death from the use of a specific product [...]" (Christoforou 2004: 644-5).

\footnotetext{
${ }^{140}$ Levidow et al. (2000) note that the 1992 OSTP guidelines were published within the context of a particularly cost-benefit conscious political climate. They posit that this climate changed somewhat with the Clinton administration, which focused more on promoting biotechnology as an environmentally friendly technology than on controlling oversight costs connected with biotechnology.
} 
EU policy documents are based on the view that there is no conclusive and comprehensive evidence on the potential effects and side effects of GM foods, and therefore mandate a "long-term socio-economic impact analysis" (König 2002: 74). Krimsky might classify this as the "complex model" of GM food and crop risk assessment which considers that "introduced genes may affect the expression of other genes in the parental plant" (Krimsky 2000: 233).

Moreover, since the adoption of EP and Council Directive 2001/18, the definition of risks connected to GMOs is intimately linked with the precautionary principle. The Directive underlines that "it is important not to discount any potential adverse effect on the basis that it is unlikely to occur" (European Parliament/Council of the European Union 2001, Annex II). A special emphasis is placed on the need to evaluate "indirect" and "delayed" effects in addition to "direct" and "immediate" effects. An "analysis of the "cumulative long-term effects' $[\ldots]$ is to be carried out as part of an environmental risk assessment (Annex II). Examples of potential risks include the "likelihood of [GM crops] becoming more persistent than the recipient or parental plants in agricultural habitats [...]" and "immediate and/or delayed effects on animal health and consequences for the feed/food chain". Further possible risks are "immediate and/or delayed, direct and indirect impacts of the specific cultivation, management and harvesting techniques" (ibid.).

Directive 2001/18 foresees a wide definition of risk, which includes not only environmental and health aspects, but also ethical and social concerns. Issues of particular concern include consumer choice and rights, the boundary between what is natural and unnatural, industry consolidation or monopoly, intellectual property rights and patenting, liability, impacts on developing countries, public involvement in decision-making, and transparency (Nuffield Council on Bioethics 1999). For Margaret Mellon, this wide definition of risk is linked to the fact that Europeans are more willing than US Americans to collectively address and take responsibility for the impact of a technology on their society, while in the US the need to address these impacts is circumvented by emphasizing "sound science" (interview with Margaret Mellon, Union of Concerned Scientists, 9 June 2004, Washington, DC). 
Risk assessment requirements Both United States and European Union regulators request technically complex and extensive risk assessments in order to grant GM foods and crops authorization. As a general rule, however, the US system is more flexible and case-by-case oriented than the EU's rules, thus leaving more space for discretion, exceptions and exemptions. This quality also makes US regulation more permissive than EU regulation. Alistair Clemence of Monsanto confirms that in his view, "data requirements are universal. It's the way in which the regulatory process works that is different from country to country" (interview with Alistair Clemence, Monsanto, Brussels, 15 September 2004, Brussels).

Under the National Environmental Policy Act (NEPA), APHIS and EPA must require environmental assessments (EAs) to determine the environmental impact of GM foods and crops. EAs are relatively concise documents, drafted by parties introducing or registering plant pests or pesticides. In practice, APHIS requires Environmental Assessments only if new species and modifications are involved, but exempts "notified" field trials from this requirement. As described in Chapter 3, the matching "notification" process, which has come to apply to most GM crop field testing, requires little information as compared to the more demanding procedure of applying for a permit.

APHIS approval of nonregulated status requires the submission of experimental data and an environmental assessment. EAs are used by regulatory agencies to determine whether a more detailed statement called an Environmental Impact Statement (EIS) ${ }^{141}$ should be required or not. If not, a so-called "Finding Of No Significant Impact" (FONSI) is issued. To date, no nonregulated status petition has led to an EIS. In the case of EPA, the agency "is responsible for establishing what data is needed to assess risks" on a case-by-case basis since the new section of 40 CFR 174 is not yet completed (Krimsky/Murphy 2001: 10-11).

For FDA, by the time a GM food has advanced to the marketing stage, its potential impact on the environment is perceived as being low, or, in any case, oversight is seen as not being cost-effective:

${ }^{141}$ An Environmental Impact Statement (EIS) is a detailed document of usually 50-70 pages that covers the purpose, need, and possible alternatives for the action, as well as short and long-term environmental effects. 
"The agency has determined [...] that this action is of a type that does not individually or cumulatively have a significant effect on the human environment. Therefore, neither an environmental assessment nor an environmental impact statement is required" (Food and Drug Administration 1992: 23005).

In contrast, EU risk assessment requirements are clearly laid out in EP and Council Directive 2001/18 on environmental release. It foresees a long and complex environment risk assessment described in Annex II, which applies to Part B and Part C of the Directive, and to EP and Council Regulation 1829/2003 on food and feed. In accordance with the EU's wide definition of potential risks in connection with GMOs, an applicant submitting an environmental risk assessment must address a long list of direct, indirect, immediate and delayed effects on human and animal health, and on the environment. These go beyond environmental and health considerations to include social and economic aspects such as GMOs's potential impacts on agricultural management and harvesting techniques.

Moreover, EU rules and regulations no longer foresee the possibility of an expedited procedure. Under EP and Council Regulation 258/97 (European Parliament/Council of the European Union 1997), the substantial equivalence clause allowed a simplified approval procedure under article 5, as described in earlier chapters. In the late 1990s, however, this clause was widely criticized by GM food critics and by some Member States as being too permissive. As a result, EP and Council Regulation on feed and food of 2003, which replaces Regulation 258/97, does not contain a substantial equivalence clause. Every GM food must now go through the same procedure.

\section{Risk-taking and judicial systems}

The US and the EU's different approaches to risk are also reflected in the distinct ways in which the state intervenes in the case of market failure ${ }^{142}$ in the EU and the US.

${ }^{142}$ In economic theory, market failure is defined as any situation in which the free market is incapable of finding an efficient outcome without intervention. Said somewhat differently, it can be a condition that arises when unrestrained operation of market forces yields socially undesirable 
In the US, the philosophy underlying GM food policy is that the federal government should remain as disengaged as possible and not intervene as long as the market performs as it should. ${ }^{143}$ If a market failure does occur, the US jurybased judicial system intervenes afterwards. In this system, a civil court may award both compensation and punitive damages (fines) which can be very high (CambsQuality 2004). For example, biotechnology company Aventis paid millions of dollars to US farmers and grain elevator owners to compensate for financial losses resulting from the StarLink affair (25 cents per bushel of StarLink or contaminated corn).

Moreover, the US jury-based system allows class action suits, i.e. lawsuits brought by one or more plaintiffs on behalf of a larger group of individuals who have a common interest. ${ }^{144}$ It is easier for individuals to bring a claim in the US than in Europe as lawyers are allowed to take on cases on a contingency fee basis. This means that the individual is not required to finance the case him or herself. Instead, his or her lawyers are paid a percentage of the damages if they win a case. The result is that US lawyers have an incentive to sue for very high maximum damages as their compensation depends on it. This type of agreement is generally not allowed in the EU.

These features of the US legal system encourage biotechnology companies to fully comply with all existing obligatory and voluntary regulatory procedures in order to discourage damage claims, especially since agricultural biotechnology developers have had trouble finding companies to insure GM food liability. Indeed, both in the US and Europe, existing insurance connected to GM foods is usually limited both in terms of scope and financial coverage (Kumar 2004).

In contrast, the EU regulatory system is a model in which the state regulates GM food in order to prevent market failures such as environment or health-related problems before they can occur. The focus is on protecting health

results. In the case of GM foods, a resulting health or ecological problem would be considered a market failure in which the state must intervene.

${ }^{143}$ Following this logic, Calestous Juma suggests that "in the US, the market puts pressure on regulation to remain permissive and flexible" (interview with Calestous Juma, Harvard University, 25 June 2004, Cambridge, MA).

${ }^{144}$ Within a context of business globalization, some European countries have taken first steps towards adopting the concept of class actions (Wegener/Fitzpatrick 2005). 
and the environment even if growth is hampered in the process. There is less reliance on the judicial system to correct problems after a failure, a fact that is connected with the above-mentioned lack of a class action tradition based on contingency fees, as well as comparatively high court fees (Wegener/Fitzpatrick 2005). The judicial system also provides less of a deterrent for industry since judges (not juries) merely award compensation to victims of product defects in a civil court. Additional fines can be levied only after a successful criminal prosecution (CambsQuality 2004). Potential plaintiffs therefore have lowered expectations as to the money they might expect to obtain from a defendant and, in most cases, bear a substantial personal financial risk. Most court cases involving GM food in Europe have so far been connected with the destruction of field test plots (Smyth et al.: 28).

\subsection{Conclusion}

Empirical study indicates that GM food policy in the US and the EU is built on different underlying paradigms as summarized in Table 15. As suggested by proposition 2 , these different paradigms help to explain the transatlantic rift in genetically modified food. In the US, the economic competitiveness and sound science paradigms are predominant, and favor a relatively permissive GM food policy. In the EU, environmental and health protection and precautionary principle paradigms define EU policy, and render GM food policy relatively restrictive. At the same time, this chapter reveals that both US and EU policies contain "opposite" paradigm elements. In other words, US policy contains protection and precautionary elements and the EU includes competitiveness and sound science elements. Overall paradigms are a result of the weighting and balancing of priorities. This chapter has shown that the US and EU policies contain clear priorities: for the US, competitiveness and sound science comes first, whereas the EU privileges protection and precaution.

It is further useful to link these paradigms to dimensions that are common to the US and the EU cases, and that enable them to be better understood. The paradigms of competitiveness and protection are coupled with agriculture and based on two different models of agricultural growth. In the case of sound science and the precautionary principle, risk is an essential dimension. The sound 
science principle is based on a narrow risk definition, whereas the precautionary principle is based on a wide definition.

It is apparent from this chapter that the paradigms discussed are connected, and that they have links to the preceding policies discussed in the previous chapter. The rDNA debate and the sociopolitical context in the US in the $70 \mathrm{~s}$ and $80 \mathrm{~s}$ formed the basis for the sound science and competitiveness paradigms in the area of agricultural biotechnology. In the case of the EU, the precautionary and the protection paradigm are both the expression of the EU's tendency to attempt a complicated balancing act between opposing goals. As will emerge in the following chapter, paradigms are also clearly visible in the socalled "story-lines" or discourses that determine the goals and activities of actors and actor coalitions in the GM food policy debate.

Table 15: US and EU paradigms

\begin{tabular}{|c|c|}
\hline United States & European Union \\
\hline Economic competitiveness & Environmental and health protection \\
\hline $\begin{array}{l}\text { - creating a secure regulatory environment for } \\
\text { industry }\end{array}$ & $\begin{array}{l}\text { - protecting consumers and environment from } \\
\text { GMOs }\end{array}$ \\
\hline $\begin{array}{l}\text { - agriculture as business with great relevance } \\
\text { for trade }\end{array}$ & $\begin{array}{l}\text { - agriculture to move towards sustainability } \\
\text { model }\end{array}$ \\
\hline Sound science & Precautionary principle \\
\hline $\begin{array}{l}\text { - science as an infallible source of } \\
\text { information }\end{array}$ & $\begin{array}{l}\text { - science as a possible source of uncertainty } \\
\text { and unanswered questions }\end{array}$ \\
\hline $\begin{array}{l}\text { - narrow definition of risk, comprising only } \\
\text { short-term effects on health and the } \\
\text { environment }\end{array}$ & $\begin{array}{l}\text { - broad definition of risk, including long- } \\
\text { term, delayed effects, and socioeconomic } \\
\text { effects in addition to short-term effects }\end{array}$ \\
\hline $\begin{array}{l}\text { - judicial system encourages corrective role of } \\
\text { the courts after commercialization }\end{array}$ & $\begin{array}{l}\text { - judicial system encourages preventive role } \\
\text { of state before commercialization }\end{array}$ \\
\hline$\rightarrow$ relatively permissi & $\rightarrow$ relatively restrictive regulation of GM food \\
\hline
\end{tabular}




\section{ACtors AND ACtor CoAlitions: Different LeVels of SUCCESS}

Both in the US and the EU, a search for key players in the GM food policy debate reveals two main types of actors and actor coalitions: those fundamentally opposing agricultural biotechnology, and those actively promoting it. Proposition 3 suggests that in the US, actors and actor coalitions supporting GM food have been more successful than GM food critics, and that they have therefore been able to push for permissive regulation of GM foods and crops. In the EU, on the other hand, the proposition expects that actors and actor coalitions opposing GM food have been more successful than GM food supporters, and have obtained restrictive GM food and crop policies.

Accordingly, in this chapter, I investigate whether and how pro-GM food actors and actor coalitions have been able to obtain relatively permissive GM food policies, and to what extent anti-GM actors and actor coalitions have achieved relatively restrictive GM food policy. As explained in Chapter 4, I make use of the concepts of "advocacy coalition" and "discourse coalition" to assess levels of coalition success. The argument developed here on the basis of my empirical findings is that coalitions are most successful when they combine the goal-oriented and coordinated activity of advocacy coalitions, and the deeply ideological story-lines that characterize discourse coalitions. In my empirical discussion, I emphasize concepts from the Advocacy Coalition Framework (ACF) and the argumentative approach that are both particularly useful and representative. From within the ACF, I make use of the notion that actors and coalitions act rationally and are guided by specific interests and goals, as well as the idea that these coalitions engage in coordinated action. From within the argumentative approach, I emphasize the concept of story-lines that hold together coalitions, as well as the idea that particular story-lines are successful when they reach discourse dominance. I also pay specific attention to the potential impact of context factors. $^{145}$

${ }^{145}$ This chapter relies mainly on two sources: a series of semi-directive interviews conducted with US and EU actors in the GM food debate, and primary documents written by these and other 
The analysis in this chapter focuses on actors and actor coalitions after the mid-1990s since this is when the controversy surrounding GM foods and crops began. For both the US and EU cases, I first present actors and actor coalitions in terms of their positions, interests and shared story-lines, then investigate the role and impact of shock events, and finally discuss actors' and actor coalitions' activities in pursuing their policy goals.

\subsection{Actors and actor coalitions in the United States}

\section{US actors and actor coalitions in favor of GM food and crops}

Over the past decade US actors in favor of GM foods have been very successful in achieving their policy goal of relatively permissive regulation. As this section will show, a main reason for this success is that in the US, GM foods are supported throughout the food chain, as well as and by regulators. This support is motivated by common goals and common story-lines. Moreover, in comparison with their European counterparts, GM food proponents in the US have faced relatively mild shock events and a fairly disengaged public.

Actors Main US actors supporting and promoting, or at least not actively opposing or hindering agricultural biotechnology, are multinational agricultural biotechnology companies, large-scale farms using intensive farming methods (“agribusinesses"), as well as food processors, producers, and retailers. ${ }^{146}$ Further supportive actors are a majority of US states and the US federal government, in particular the White House and the State Department - mainly regarding trade issues -, as well as the regulatory agencies dealing with agricultural biotechnology (FDA, EPA, and APHIS). As GM food regulators, these governmental actors are not part of the more formal activities of GM food proponents, but their informal collaboration with pro GM food actors is

actors, many of them drawn from organizations' and institutions' websites. A third source is secondary literature describing and analyzing the GM food policy process and debate.

${ }^{146}$ US researchers in the field of molecular biology are for the most part also supportive of GM food. They are not discussed in this chapter, however, because they do not appear in the GM food debate as prominently as was the case in the 1970s when the debate was about rDNA researcher's stakes were higher. As of the 1990s, they are less important as players in the GM food debate than the other actors discussed in this chapter. 
indicative of their support and crucial to understanding why GM food policy is relatively permissive in the US.

Main agricultural biotechnology companies with US headquarters are Monsanto of St. Louis, Missouri, the world's largest genetically engineered seed business, and DuPont-owned Pioneer Hi-Bred of Des Moines, Iowa. "Agribiotech companies", as they are often referred to, are represented in Washington, DC by the Biotechnology Industry Organization (BIO). Biotechnology companies devote vast resources to supporting GM foods, both individually and through BIO.

Since a large proportion of the GM seed produced is herbicide tolerant, the GM seed market is intimately linked with the pesticide market. Monsanto commands $9 \%$ of the pesticide market, and between 80 and $88 \%$ of the GM seed market. DuPont controls $6 \%$ of the pesticide market, and shares the remaining 12 to $20 \%$ of the GM seed market with Syngenta and Bayer CropScience, both headquartered in Europe (ETC Group 2005a, 2005b). Monsanto unquestionably is the giant of agricultural biotechnology. As Bernard Graciet, Head of Syngenta's Brussels Office, explains, "Monsanto bet on adopting green biotechnology as a priority over chemicals. Monsanto bet on the replacement of pesticides $^{147}$, whereas Syngenta thinks that both are necessary"; moreover, "the big difference between Monsanto and other agricultural biotechnology companies is that Monsanto makes important profits from agbiotech, while other companies invest in biotech research, but do not yet make a profit in this sector"(interview with Bernard Graciet, Syngenta, 15 September 2004, Brussels).

Large-scale farms or agribusinesses are found mostly in the American Midwest and are represented by the American Farm Bureau Federation (AFBF or Farm Bureau). Depending on the crops they produce, US farmers also look to organizations like the American Soybean Association (ASA), the National Corn Growers Association (NCGA), and the US Grains Council for representation. Farm Bureau is funded by membership dues and voluntary contributions, and is skillful at raising funds. Supporting agricultural biotechnology is one of its priorities.

${ }^{147}$ At the same time, Monsanto is the number one producer of herbicides containing glyphosate, the active ingredient in its "Roundup" herbicides. Monsanto's Roundup Ready GM crops are engineered to tolerate glyphosate. 
The third main group supporting agricultural biotechnology consists of food processors and producers, as well as retailers. Main US food processors and producers include Kraft Foods, ConAgra, and Archer Daniels Midland. Major associations representing them are the Food Products Association (FPA) (former National Food Processors Association, NFPA) and Grocery Manufacturers of America (GMA). Large US food retailers are supermarkets such Wal-Mart, Kroger, Albertson's and Safeway. As is the case for food producers, many US retailers are present on both sides of the Atlantic. For example, Wal-Mart owns the UK supermarket chain ASDA. Food retailers operating in the US are represented by Grocery Manufacturers of America (GMA). For the case of the US, food processors, producers and retailers are discussed together because their positions and story-lines are very similar. In addition, they are in part represented by the same associations, in particular GMA. The food processing, producing and retailing industry also devotes a significant amount of resources to the topic. Like Farm Bureau and BIO, GMA and the FPA are well-funded lobbies.

Within the US federal government, the most vocal supporters of agricultural biotechnology are the Office of Science and Technology Policy, the Food and Drug Administration ${ }^{148}$, and the Animal and Plant Health Inspection Service. True to its mission of protecting the environment, the Environmental Protection Agency displays support of a somewhat more cautious nature, but does not fundamentally question the relatively permissive nature of US policy. Federal resources devoted to publicizing information about agricultural biotechnology and its regulation have been considerable over the past decade. Most of the fifty US states are also supportive of federal policy, especial states in the American Midwest, where most GM crops are grown.

$\underline{\text { Positions and interests }}$ All the actors presented, including governmental actors, are in favor of relatively permissive and product-based regulation of GM crops and foods, with as few labeling requirements as possible. Therefore, the goal of supportive actors has been to keep in place the relatively permissive, product-based US regulatory framework devised in the 1980s, stretching it to make adjustments when necessary. As early as 1990, key food industry actors

${ }^{148}$ FDA officials Ricker and Garcia would describe FDA as "not explicitly supportive of any given technology [and suggest that] a better formulation would be that we do not discriminate against biotechnology or other methods of manufacture" (interview with Karin Ricker and Edmundo Garcia, Jr., Food and Drug Administration, 10 June 2004, Washington, DC). 
had agreed that "no new regulations are needed for food and food ingredient products from sources that are genetically modified $[\ldots]$ " and that a "flexible, tiered-approach system of safety evaluation that is guided by decision trees" would be the best type of regulation (International Food Biotechnology Council 1990: xvii-xviii). These recommendations, applauded by other GM food supporters, had an important level of influence, especially on FDA policy (interview with Jeffrey Barach, Food Products Association, former National Food Processors Association, 15 June 2004, Washington, DC). Pro-GM food actors are critical of the EU's process-based policies and support decisive action against what they perceive as the European Union's “imposition [...] of trade restrictions" (American Farm Bureau Federation 2005). Ron Gaskill of the American Farm Bureau Federation expresses what many US actors think of the EU's policies on GMOs when he states that: "the European regulatory position is illogical" (interview with Ron Gaskill, American Farm Bureau Federation, 9 June 2004, Washington, DC).

Pro-GM food actors have somewhat differing but interrelated interests in promoting GM crops and foods. As documented by position papers, the agricultural biotechnology industry, as developer of GM crops and producer of GM seeds worldwide, strongly supports and promotes its products and is primarily profit-oriented. Contrary to what is sometimes thought, industry prefers flexible and relatively permissive regulatory oversight to no oversight at all. Food and Drug Administration officials explain that from biotechnology companies' perspective, having a "stamp of approval" is very important for market success. This explains why the FDA has, to date, been consulted on all GM products before they have entered the US market even though this procedure is voluntary (interview with Karin Ricker and Edmundo Garcia, Jr., Food and Drug Administration, 10 June 2004, Washington, DC).

After the agricultural biotech industry, large farms or agribusinesses are the actors that stand to gain most from GM crops such as herbicide-tolerant and insect-resistant soybeans, corn and oilseed rape. Particularly when used on large areas, GM crop varieties can produce substantial benefits to farmers including less need for tillage, lower labor costs, reduced use of pesticides, higher yields, and greater profits (Madsen et al. 2003). Major GM crops were indeed developed by companies like Monsanto and Pioneer Hi-Bred primarily for US Midwestern 
farmers who are the main beneficiaries of the technology, and therefore their main clients.

The interests of US food processors, producers and retailers are the least clear-cut within the food chain. More than the biotechnology industry and largescale farmers, these actors depend on consumers for profit, and they are the first to feel the impact of consumer preferences. When the first GM foods and crops were introduced in the mid-1990s, food processors, producers and retailers in the US viewed these products as an innovation that would lead to benefits not only for farmers, but also for consumers and therefore to greater profits for themselves. They therefore enthusiastically endorsed them. When European consumers rejected GM foods in the late 1990s, US food processors, producers and retailers feared a similar backlash in the United States. However, despite the several shock events described in Chapter 2 and in this chapter, the mainstream US consumer has not turned against GM foods in a major way. Thus, for the moment, there is no compelling reason for food processors, producers and retailers to distance themselves from the successful pro-GM food coalition in the US. ${ }^{149}$ Their interests and positions, however, clearly depend on consumer reactions and preferences, and therefore have the potential to change relatively quickly. Jeffrey Barach describes the situation as follows:

"NFPA has not really changed its policy on genetic engineering of food over the years, but it has refined it. We have become more attentive to food chain issues and realized that we cannot look only at the food producer segment of the food chain. We have to look from the researcher to farmers to the elevators to processing to the final consumer. StarLink and the development of PMPs have made us particularly attentive to food chain issues" (interview with Jeffrey Barach, Food Products Association, former National Food Processors Association, 15 June 2004, Washington, DC).

\footnotetext{
${ }^{149}$ From the point of view of some stakeholders, however, food industry and retailer support for GM products is not as strong as it might be. Ron Gaskill of AFBF suggests that US retailers are "trying to duck" and that they would prefer to not be involved with genetic engineering "to avoid a headache". This is also a reaction to the European stance and a result of the fact that there is a lot of integration between large US and large European retailers (e.g. Royal Ahold, Carrefour, Sainsbury's) (interview with Ron Gaskill, American Farm Bureau Federation, 9 June 2005, Washington, DC).
} 
The interests of US governmental institutions and the reasons for their pro-GM stance have been discussed in the chapter dedicated to paradigms. In summary, the US government, including its regulatory agencies, supports the US biotechnology industry in the context of a policy prioritizing economic growth and competitiveness.

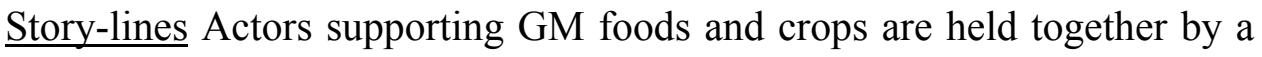
powerful story-line, and thus represent a strong discourse coalition. Some actors tell this story in a more outspoken manner than others, but all agree on its basic elements.

The story-line is based on the fundamental belief, shared by governmental and non-governmental actors alike, that science and technology bring about advancement, and that they are inherently virtuous and unbiased. Agricultural biotechnology is therefore synonymous with progress. This element links back to both the sound science and the competitiveness paradigms introduced in Chapter 6.

An important part of the story is also the viewpoint that genetic engineering is viewed as an extension of conventional breeding. The Food Products Association and Grocery Manufacturers of America both emphasize that the concept of enhancing food production techniques is not new, since "[f]or centuries farmers have selectively bred plants to pass on desirable traits (Food Products Association What is Food Biotechnology?). GM foods should therefore be assessed according to the risks they present. Karil Kochenderfer of Grocery Manufacturers of America explains that

"the question is how to manage [risks] in a way that allows for safe products to go to market. A government's job is to harness a technology's benefits and manage its risks. We call that process the 'risk paradigm'. The EU, in comparison, has a 'hazard paradigm'. The idea is to identify the hazard and regulate to eliminate it. What is the difference between the hazard and risk paradigms? The hazard paradigm only recognizes that there is a danger inherent to a product. The risk paradigm recognizes the danger, but also examines how frequently it occurs. Risk is hazard times frequency" (interview with Karil Kochenderfer, Grocery Manufacturers of America, 17 June 2004, Washington, DC). 
Many Farmers also take the approach that crops grown with the help of agricultural biotechnology are not a fundamental departure from other modern varieties. As summarized by Hayden Milberg of National Corn Growers Association, "all modern cultivated crops are modified to some extent. [...] We view biotechnology as an additional tool in the farmer's toolbox which can help meet production needs" (interview with Hayden Milberg, National Corn Growers Association, 9 June 2004, Washington, DC). US agencies also emphasize this aspect of the pro-biotech story-line in numerous policy documents.

In addition, the story-line emphasizes that biotechnology benefits agriculture, the environment and consumers alike. With regard to the environment, the story goes that the use of GM crops enables farmers to considerably cut down their use of herbicide as well as tillage, which decreases soil erosion. With respect to possible risks, BIO carefully explains that potential negative effects on health and the environment have been scientifically proven to be negligible.

Food processors, producers and retailers especially emphasize the benefits of biotechnology for consumers. Jeffrey Barach of the Food Products Association explains that

"we are looking for foods that are safe and wholesome and can get to the consumer in the best form possible. Any technology [like genetic engineering] that can do that interests us" (interview with Jeffrey Barach, Food Products Association, former National Food Processors Association, 15 June 2004, Washington, DC).

Karil Kochenderfer of the Grocery Manufacturers of America adds that:

"society constantly introduces new products and always tries to improve efficiency and performance. The challenge is to make sure that there is a perceived consumer benefit to that effort" (interview with Karil Kochenderfer, Grocery Manufacturers of America, 17 June 2004, Washington, DC)

GMA and FPA's story-lines are implicitly based on free market values, and center on consumerism. According to their story-line, not only will food supplies be more abundant and healthier, but they will also be better-tasting and 
provide a healthier diet to consumers. FPA announces that soon, "fruits and vegetables may be able to resist drought. We may remove allergens from foods such as nuts. Scientists may develop plants that absorb nitrogen more efficiently and need less fertilizer. The benefits are nearly endless!" (Food Products Association What is Food Biotechnology?). The GMA and FPA websites make little mention of dissenting voices, which may give their very positive story-lines a somewhat naive quality in the eyes of readers acquainted with the GM food controversy. An exception is made for trade: EU regulations are conceptualized as an unjustified and "serious trade barrier" since "there is no safety or nutrition issue associated with the products of agricultural biotechnology" (Food Products Association 2004). Kochenderfer summarizes GMA's position succinctly: "If the science says these products are safe, political preferences should not be keeping US products out of the EU market" (interview with Karil Kochenderfer, Grocery Manufacturers of America, 17 June 2004, Washington, DC).

A further particularly controversial element of the pro-biotech story-line is that if "coupled with important developments in other areas", GM crops can "assist in meeting the food demands of a growing global population", i.e. developing nations, for example by improving the efficiency of production and the quality of the food supply (Biotechnology Industry Organization Frequently Asked Questions On Agricultural Biotechnology). Hayden Milberg of the National Corn Growers Association voices a similar view as a representative of US corn growers in stating that "the only way to feed the world as population around the globe increases is to grow more food on less land. Biotechnology has proven itself to be able to meet that challenge" (interview with Hayden Milberg, National Corn Growers Association, 9 June 2004, Washington, DC).

All the above-mentioned organizations and stakeholders use positive and upbeat language. BIO shows its thoroughly enthusiastic and confident approach with its slogan "Partner to a Dynamic Industry Coming of Age" (Biotechnology Industry Organization. About BIO: Partner to a Dynamic Industry Coming of Age). Similarly, Farm Bureau projects an image of the American farmer as the producer of "the world's highest quality food and fiber". This story-line, complete with symbolic references to the US constitution, claims and defends the freedom to produce crops and foods improved through genetic engineering. Farm Bureau's fundamental beliefs are cogently summarized in the assertion that 
"America's unparalleled progress is based on freedom and dignity of the individual, sustained by basic moral and religious concepts" (American Farm Bureau Federation We are Farm Bureau).

What allows industry and food processors, producers and retailers to act so self-assured about GM foods and its benefits while other US actors make opposite claims? It is not only their belief in science, but also in the US regulatory system. According to $\mathrm{BIO}$, "rigorous scientific reviews" and "extensive field testing" have led to "scientific consensus [which] continues to inform US regulatory policy." In BIO's view, the United States is particularly fortunate in this respect: "many countries have not enjoyed a reliable regulatory environment like that in the United States" (Biotechnology Industry Organization Frequently Asked Questions On Agricultural Biotechnology).

\section{US actors and actor coalitions against GM foods and crops}

Actors opposing GM foods and crops in the US have been less successful than actors supporting them. Since the Coordinated Framework of 1986, agricultural biotechnology proponents have not succeeded in rendering US GM food policy more restrictive. This can be explained in part by the fact that these actors have somewhat different positions, interests, and story-lines, and a relatively modest level of coordinated activity. Moreover, the US anti-GM food coalition's lack of success is connected to a relative lack of public and media interest regarding the issue of GM foods, and to the relatively mild role played by shock events in awakening such interest.

Actors US actors opposing the development and use of agricultural biotechnology and favoring restrictive regulation are small-scale, family and organic farmers, consumers, and environmental and public interest groups. Some members of the US Congress and some US state legislatures have also played a role in calling attention to issues of concern in connection with GM foods.

Family farmers and organic farmers are found throughout the US, including in the American Midwest, where many of them have been merged into larger farm operations. Family farmers are represented by associations and organizations such as the National Family Farm Coalition (NFFC) and 
specialized associations like the American Corn Growers Association (ACGA). Organic farmers, represented by numerous regional and state organizations, are also opposed to GM foods. These groups are funded by their members and by donations; they are represented by small staffs in Washington, DC.

US consumers concerned about genetic engineering in food are represented by Consumers Union (CU) and by smaller groups such as the Organic Consumers Association. Main environmental groups in the United States are the US sections of Greenpeace and Friends of the Earth. Further organizations worth noting, which form an important part of the GM food-critical coalition in the US, can be described as hybrids between environmental and public interest groups. Key organizations are the Center for Food Safety (CFS), the Council for Responsible Genetics (CRG), the Union of Concerned Scientists (UCS), and the United States Public Interest Research Group (US PIRG). These groups are generally funded by membership dues and donations, some by individuals and some by foundations. They do not receive government or corporate funding; Greenpeace even has a policy against acceptance of such funding. Their resources are considerably limited in comparison with corporate actors. The US Congress and some US state legislatures cannot be classified as being consistently opposed to GM foods, but some members of Congress and certain state legislatures have been known to highlight issues of controversy. Finally, the US Green Party, which is opposed to GMOs and GM foods, is not very vocal or present in the US debate. It does not have the weight that some European Green parties do, in large part because of the US two-party system, but its base of support has been increasing in recent years.

Positions and interests US actors critical of GM foods and crops adopt comparable positions and make similar demands regarding regulation. They call for a more demanding and rigorous approval process, which is mandatory during the commercialization phase. They request a process-based approach as well as the labeling of GM foods. Some groups advocate an explicitly precautionary line and wish to see a ban on new GM foods and crops until they are proven safe.

Their interests differ somewhat, but are not incompatible and lead to similar positions. The main goal of small farmers' is to stay in business by halting or at least slowing the trend towards concentration in agriculture. Organic 
farmers' interest in opposing GM foods is to increase their own market share since organic foods may not be genetically engineered under US national standards for organic foods.

In contrast to the actors represented so far, consumers are a very broad category, theoretically comprising every US American. In the GM food debate, however, these individual consumers are represented by consumer organizations. These organizations' success depends on consumers' trust and attention, so it is in their interest to critically address topics of concern and importance to consumers, such as genetically modified foods. Regarding the issue of GM foods, consumers' first and foremost want their health to be protected. They also want a transparent information system when buying produce. Consumer organizations' mission is therefore to inform consumers and protect their health and rights.

Further key actors are environmental groups, whose mission is to protect the environment. Since these groups do not get direct input from the environment in the same direct way that BIO does from Monsanto or GMA from Kraft Foods, they decide on their agendas and priorities autonomously. Moreover, environmental groups have individual members supporting them out of conviction, but they are not accountable to these individual members in the same way that an industry representation is accountable to a dues paying member industry. Environmental groups therefore generally do not have an elaborate internal process for developing policy priorities and positions. By and large, it is in environmental organizations' interest to have the freedom to select environmental issues that attract attention and membership, thereby securing the success and growth of the organizations. ${ }^{150}$ Depending on how much emphasis they put on serving the public interest, "hybrid" environmental and public interest groups are in similar situations, balancing a mission of protecting the environment and the public interest with a need to stay in business.

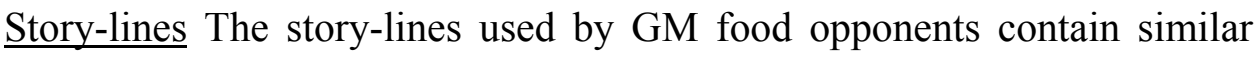
elements despite somewhat differing focuses. An important difference lies in the

\footnotetext{
${ }^{150}$ Accordingly, a criticism often voiced by industry representatives is that environmental groups, although they have dues paying members, are not governed by a democratic process, and that they select issues consistent with their goal of being successful organizations. One interviewee illustrates this point well by stating that "you cannot escape the fact that this has been a hugely motivating campaign for NGOs. It's a high priority campaign for Friends of the Earth and Greenpeace, so it must be a popular campaign and it must be a money-spinning campaign".
} 
language that they adopt to communicate their goals and positions. Different rhetoric points toward different degrees of activism. Generally, groups mainly concerned with the environment (Greenpeace, Friends of the Earth, Center for Food Safety) are more outspoken than organizations that consider themselves consumer groups (e.g. Consumers Union) or representatives of a specific interest (e.g. National Family Farm Coalition) or of a particular issue (e.g. Council for Responsible Genetics). Exceptions are the US Public Interest Research Group, a relatively outspoken public interest group, and the Union of Concerned Scientists, an environmental group that focuses more than other groups on developing positions that are scientifically sound ${ }^{151}$ (interview with Margaret Mellon, Union of Concerned Scientists, 9 June 2004, Washington, DC).

An element common to each of these groups' story-lines is that genetic engineering is fundamentally new and that it is by no means just a continuation of conventional breeding techniques. Consumers Union represents the viewpoint of this group of GM opponents when it writes that genetic engineering is "a quantum leap" away from conventional breeding since it makes possible the creation of "what can be regarded as synthetic life forms" (Consumers Union 1998a). For these actors, scientists are fallible and cannot be trusted blindly.

All the groups discussed also agree that GM foods might pose a threat to health and the environment, although they vary in their levels of conviction about this. Greenpeace and Friends of the Earth's positions are based on an image of a planet plagued by environmental problems. GM foods are one of these many problems because they are unnatural and their development and marketing is based entirely on the profit motive: "when we force life forms and our world's food supply to conform to human economic models rather than their natural ones,

${ }^{151}$ The unique nature of the Union of Concerned Scientists (USC) is worth mentioning. UCS members are citizens, some but by no means all of them scientists, concerned with environmental issues. UCS "augment[s] rigorous scientific analysis with innovative thinking and committed citizen advocacy to build a cleaner, healthier environment and a safer world" (Union of Concerned Scientists About UCS). Founded in 1969 by students and faculty of the Massachusetts Institute of Technology (MIT), UCS is concerned about potential abuses of science and technology in society, aims to "persuade" and "urge" regulatory agencies to conduct "rigorous reviews of ecological risks" and "require safety testing and labeling before biotech foods are allowed on the market" (UCS Biotechnology). This type of formulation hints at argumentation on the basis of scientific arguments more than on the basis of ethical and social issues. Indeed, USC views itself as separate from other organizations: "The Union of Concerned Scientists stands out among environmental organizations as the reliable source of sound scientific information. UCS is the most effective group to combine credible scientific analysis with effective citizen advocacy to bring about policy change" (UCS How UCS is Unique). 
we do so at our own peril" (Greenpeace International Say no to genetic engineering). In the words of Friends of the Earth USA, allergic reactions to GM foods have already shown that genetic engineering of food is "a major gamble with human health" and that "genetic engineering gives pollution a life of its own" (Friends of the Earth USA Organic, not genetically engineered). Expected long-term effects include mutations, transfers to other plants and "superweeds" that are resistant to herbicide. For CFS and US PIRG, risks can include not only allergenicity, antibiotic resistance and the "contamination" of non-GM plants and ecosystems, but also cancer, plant and animal extinction, poisoning of the soil, and increasing world hunger.

Other environmental and public interest actors are skeptical but less fundamentally condemnatory. The Union of Concerned Scientists makes claims of a less sweeping scope than Greenpeace or Friends of the Earth USA. For example, it speaks of engineered crops that might contaminate the food supply with drugs (in the case of plant-made pharmaceuticals) or kill beneficial insects. One of its main views is that there should be "an open-end process in adopting new technologies. There should be more participants than just government, business, and the scientific community. All three of those groups have short-term interests $[\ldots]$ we are interested in slowing technology down" (interview with Margaret Mellon, Union of Concerned Scientists, 9 June 2004, Washington, DC).

Consumers Union, although it is a major GM food critic, paints a mixed picture of the technology: GM foods may be full of potential, but they may also harbor many risks. Genetic engineering may be precise in achieving specific results, but its wider effects are unpredictable and may have adverse effects on human health and the environment. Consumers Union further stresses possible effects on health which may include toxicity, allergies and resistance to antibiotics due to the use of antibiotic resistance markers in genetic engineering. It also addresses hazards that reach beyond health issues. For $\mathrm{CU}$, the most important thing is the consumer's right to choose between GM foods and nonGM foods.

Like other GM food opponents, US family farmers point out that the scientific knowledge underlying agricultural biotechnology is insufficient, thus in effect requesting the application of the EU's precautionary principle that was 
described in the previous chapter. They particularly fear environmental effects such as contamination of non-GM plants and ecosystems, increased pest and weed resistance, and the destruction of wildlife and beneficial insects. Katherine Ozer of the National Family Farm Coalition explains that "We have a sense that this technology is being imposed on farmers [...] without being adequately tested, without anyone really knowing what the negative implications could be [...]" (interview with Katherine Ozer, National Family Farm Coalition (NFFC), 7 June 2004, Washington, DC).

A further common point of GM food opponents' story-line is a general disapproval of the activities and motivations of big corporations. Environmentalists base their policies on the deeply held belief that big business is consistently motivated by profit and shareholder value, often to the detriment of the environment. A main theme in the writings of Greenpeace USA, Friends of the Earth, CFS and US PIRG is the deception practiced and environmental harm caused by corporations. They tell a story of a planet earth that is ruthlessly and continuously abused by agribiotech industries. The health of innocent citizens of this earth is also endangered, and they are increasingly left without the possibility to make a desirable ethical choice against GM food. They are further convinced that it is wrong to allow companies to claim intellectual property rights over plant technologies. US PIRG summarizes this point by stating that "[i]n general, these crops are being engineered to increase corporate profitability, not to alleviate world hunger" (US Public Interest Research Group What isn't the biotech industry telling you?).

True to the farms it represents, the National Farm Family Coalition (NFFC) takes a somewhat different approach, although it also agrees with many of the points raised by environmental NGOs and public interest groups. NFFC deplores agribusiness concentration, it sees as putting the livelihood of individual small farmers at risk, and as destroying whole rural communities. Its story-line about agricultural biotechnology is less a condemnation of the genetic engineering of food than a narrative of how the increasing concentration of agribusiness threatens the livelihood and independence of family farms. The fact that companies are now patenting GM seeds, developed out of varieties that farmers have been growing for centuries, is equally unacceptable to NFFC. Katherine Ozer of NFFC states that "a central issue for NFFC is the question of 
who is in control. We see corporate control as a threat to the ability of family farmers to be independent and to make a living" (interview with Katherine Ozer, National Family Farm Coalition (NFFC), 7 June 2004, Washington, DC). According to the NFFC's "Farmers' Declaration on Genetic Engineering", GM crops and foods have "increased the economic uncertainty of US family farmers" and are threatening traditional agricultural practices in the US and around the world (National Family Farm Coalition Farmers' Declaration on Genetic Engineering). NFFC also fundamentally opposes patents on GM seed varieties, thus introducing the ethical issue of who has the right to "own" life.

GM food opponents agree that there is more at stake than just risks for the environment and health. For example, in exploring why consumers may reject GM food, CU addresses social and cultural questions. According to $\mathrm{CU}$, food is special because it is "something we literally take into ourselves". Therefore, "consumers make decisions about what they eat for a wide variety of religious, ethical, philosophical and emotional reasons" (Consumers Union 1998b). A further example is given by the Council for Responsible Genetics, which is concerned with genetic engineering in particular, and which notes that

"consumers also are concerned with the corporate ownership of seeds and genetically engineered food plants. Monopolistic business practices, the extreme consolidation of the seed industry, coupled with the patenting of seeds has led many consumers to question whether the agribusiness corporations have public welfare or private profit as top priority." (Council for Responsible Genetics 2000).

\section{Shock events}

The US's experience with GM foods and crops is marked by three main shock events: the monarch butterfly case (1999), the StarLink affair (2000), and the ProdiGene incident (2002), all described in more detail in Chapter 2. Because they led to only limited public reactions and because they were dealt with quickly and efficiently by US regulators, these incidents did not significantly set back the work of US actors and actor coalitions favoring relatively permissive GM food policies, and did not significantly help coalitions favoring restrictive regulation. 
In the case of the monarch butterfly, a scientific paper by a Cornell University entomologist provided evidence that Bt corn was harmful to monarch butterfly larvae. As reported by the Pew Initiative on Food and Biotechnology, actors critical of US policy on GM foods and crops, in this case especially the Union of Concerned Scientists (UCS) "worked very hard to make this a highprofile issue because without media attention [they] knew nothing would be done" (Margaret Mellon of UCS, cited in Pew Initiative on Food and Biotechnology 2002: 8-9). Despite this effort, however, the issue died down, probably because the EPA's regulatory response appeared to be adequate and the impact on monarch butterflies less harmful than first expected.

In the case of StarLink, traces of StarLink corn, a GM corn variety approved for use in feed but not in food, were discovered in Kraft taco shells. After this discovery, 51 consumers reported allergic reactions as a result of consuming taco shells. Roughly half of these qualified for testing, and 17 were willing to give blood samples to the Center for Disease Control and Prevention. In a report released in 2001, the Center for Disease Control and Prevention found no "evidence that the reactions that the affected people experienced were associated with hypersensitivity to the Cry9c protein" (Center for Disease Control and Prevention 2001, see also Kaufman 2001).

These events, together with the fact that StarLink producer Aventis agreed to compensate for financial losses due to StarLink, eventually resulted in the issue dying down without having created a major loss of public trust. The reactions of industry and regulators alike were swift and efficient, displaying an "in control" situation to American consumers. As summarized by Ron Gaskill of the American Farm Bureau Federation, StarLink caused little public outcry because regulators did their job: they stepped in, made the necessary inquiries and removed the product from the market (interview with Ron Gaskill, American Farm Bureau Federation, 9 June 2004, Washington, DC).

StarLink did, however, have an important effect on certain actors of the food chain. Food processors, producers and retailers realized the need to put in place certain safeguards to avoid further StarLink-type episodes. For example, they strongly recommend and have been successful in obtaining regulatory 
procedures resulting in authorizations that are always for both feed and food, and not for just feed as was the case with StarLink corn.

Like the monarch butterfly and StarLink, the ProdiGene incident did not have drastic effects on public opinion, mainly because APHIS discovered that soybeans had been contaminated with GM corn engineered to produce pharmaceuticals before they could enter the food chain. The ProdiGene incident led food producers and processors to question the use of food crops for new biotechnology applications such as plant-made-pharmaceuticals (PMPs) because they fear widespread US consumer rejection if a future such event occurs and PMPs are found to have actually entered the food chain.

In summary, although the shock events described attracted media and public attention for a while, they did not have a lasting effect on public opinion on GM food and crops, and did not undermine public trust in regulatory institutions. Birkland's statement that "[if] no advocacy coalitions react, events will gain little more than passing attention" holds true for the United States: only individual actors reacted to the shock events, but did not act as convincing advocacy coalitions (Birkland 1998: 72). Krimsky suggests that in order for there to be real public reaction, a catastrophe leading to many deaths, or a major book (such as Rachel Carson's Silent Spring, referred to above) is needed. He concludes that "StarLink drew media attention, but did not result in any deaths" and that "the monarch butterfly did cause some reaction", but not enough because it "is an insect, not a human being" (interview with Sheldon Krimsky, Tufts University, 25 June 2004, Medford, MA).

One possible reason for the US public's relative lack of reaction to these events described may be its fairly high level of acceptance of GM foods and crops. Cantley et al. write that throughout the 1990s, US consumers displayed generally positive views about GM foods (Cantley et al. 1999). Similarly, Hoban showed in 1997 that US consumers were among the most likely to purchase GM foods, compared with consumers in a series of European countries (Hoban 1997). This trend has continued into the new millennium. In 2001, around $70 \%$ of Americans were willing to buy GM foods (Falk et al. 2002: 1386-7), and in 2004, almost $50 \%$ of consumers who were told that over half of all supermarket products contain GM ingredients believed them to be safe (Pew Initiative on Food 
and Biotechnology 2004b). Mainstream consumers' only real point of criticism is that they would like to see GM products labeled (ibid.).

These high levels of acceptance and US Americans' lack of reaction to shock events might be also connected to the fact that "most Americans [are] unaware of the extent to which crops derived from biotechnology have entered the marketplace" (Falk et al. 2002: 1386). Asked in 2002 whether they had ever eaten GM foods, only $19 \%$ of Americans questioned replied that they had, although it is estimated that over $60 \%$ of processed food contain GM ingredients (ibid.). In 2004, the Pew Initiative on Food and Biotechnology confirmed that "Americans remain relatively uninformed about genetically modified foods" (Pew Initiative on Food and Biotechnology 2004b). According to critics such as the Union of Concerned Scientists, this does not mean that the public wants GM foods: "The US public is not accepting, [...] it's just passive" (interview with Margaret Mellon, Union of Concerned Scientists, 9 June 2004, Washington, DC).

The US public's support for GM foods is undoubtedly also connected to its relatively high level of trust in US regulatory institutions (Gaskell et al. 1999, Gaskell et al. 2002). Actors in the field of GM foods especially cite the Food and Drug Administration as enjoying a high level of trust, perhaps going back as far as FDA's judgment with respect to the drug thalidomide. ${ }^{152}$

According to Gaskell et al., another possible reason for different levels of public support is "media intensity" (Gaskell et al 2002: 373). US media coverage of GM food, although critical at times, is supportive or non-existent in comparison with European media, especially the UK media, which launched an all-out war on GM food in the late 1990s, and remains very critical today. A further example is the German media which, although not as sensationalist as the UK press, treats GM food as a high profile issue, a phenomenon connected with

152 Thalidomide, a drug produced by the West-German company Chemie Grünenthal, was authorized in European countries and administered to pregnant women to treat morning sickness in the late 1950s and early 1960s. At this time, the Food and Drug Administration judged that there was insufficient proof of the drug's safety and did not approve it. Thalidomide was withdrawn worldwide in late 1961 and 1962 after doctors linked it to an epidemic of birth defects.

It should be noted, however, that the public's trust in FDA with respect to pharmaceutical approvals has recently suffered as a result of a series of setbacks relating to drug safety (Harris 2005). The 2004 withdrawal from the market of the osteoarthritis drug Vioxx due to concerns about increased risk of heart attack and stroke is an example of this. 
the German public's strong concern with environmental issues, and with the importance of the German Green Party.

\section{Activity and impact on policy}

US actors supporting GM food work both individually and in collaboration, and in both formal and informal ways. Since non-governmental pro-GM food actors in the United States display relatively cohesive opinions and share very supportive views, it has been relatively easy for them to engage in both informal cooperation and coordinated activity over time. Overall, as stated above, US actors and coalitions of actors in favor of a permissive GM food policy have been able to keep policy at the permissive level set by the 1986 Coordinated Framework. Actors opposing GM foods and supporting restrictive policy, on the other hand, have been unable to present a united front and have not shown as much cohesion and cooperation as GM food supporters. They have also had to contend with the status quo of permissive GM food policy. To date, they have not been successful in achieving a change in policy.

One of the most successful individual GM food supporters is the Biotechnology Industry Organization (BIO). BIO began to launch campaigns to raise government and industry support for biotechnology and permissive policies in the 1980s, earlier than EuropaBio, its European counterpart, and earlier than many other pro-GM food organizations in the US. After GM crops and food became a large-scale and profitable business in the mid-1990s, BIO continued to represent agricultural biotechnology effectively and aggressively.

An important forum for coordinated activity created by GM food proponents is the Alliance for Better Foods (ABF). ABF's sponsors include Grocery Manufacturers of America, the American Farm Bureau Federation, the Food Products Association, and other more specialized food sector organizations. ABF, which was most active during the late 1990s, was created to lobby regulators in Washington, DC with the primary goals of promoting public acceptance and of opposing the labeling of genetically modified foods. In the words of GMA, 
"The Alliance is committed to helping people understand [the] benefits as well as the safety of using biotechnology in foods, and to providing useful and balanced information on the topic" (Grocery Manufacturers of America Biotechnology-Alliance for Better Foods).

Karil Kochenderfer of Grocery Manufacturers of America further explains that

"the Alliance for Better Foods was a collective effort along the food chain to make sure that we were talking openly and robustly about the technology. Its activities subsided primarily because that need died down. The height of its activity was between 1998 and 2001/02." (interview with Karil Kochenderfer, Grocery Manufacturers of America, 17 June 2004, Washington, DC).

A crucial semi-formal vehicle for cooperation is the AgBiotech Planning Committee. It is not widely publicized, but it is cited by most actors supporting GM foods and crops as an important and regular forum for the exchange of opinions and for the launching of coordinated actions. The AgBiotech Planning Committee, based in Washington DC, consists of organizations that represent the biotechnology industry, farmers, food processors, food producers and retailers. It typically meets once or twice a month to discuss current GM food policy issues, and to devise common positions and strategies whenever judged useful. This committee ensures that supportive actors are informed of one another's activities and positions, and puts in place a platform to plan and organize more formal joint actions. No other coalition of actors discussed in this chapter has put in place this type of forum.

An informal, but significant form of cooperation exists through the often close collaboration that exists between regulatory agencies and stakeholders. Regulators often describe their relationships with companies as "working with them" to get products approved. To biotechnology companies, regulators seem generally accessible and collaborative in their dealings with actors wanting GM products to be approved. To GM food critics, this seems like industry favoritism: "there is a very strong de facto coalition between government and industry in favor of GM food and crops" (interview with Katherine Ozer, National Family Farm Coalition, 7 June 2004, Washington, DC). 
This type of informal collaboration is denounced by GM food critics as a result of the "revolving door" phenomenon, which could be described as the fact that many individuals in industry and in government frequently change professional positions, and often switch back and forth between government and industry. The "revolving door" is a variation of the US-developed "iron triangle" concept, which refers to the close relationship between the US Congress, bureaucracy and interest groups, and has many different names, depending on the context. This phenomenon is not specific to agricultural biotechnology and is found in many sectors. It is important to mention that this phenomenon seems more widespread in the US than in the EU, where switches between industry and government, while certainly present, seem to occur less frequently. Moreover, the fact that the US government should appoint individuals who have worked for industry for many years to high responsibility and political positions points towards a deliberate search for a collaborative relationship between the regulator and the regulated.

Three prominent examples of individuals who have worked in multiple high responsibility positions in government and industry are the following: 1) Linda Fisher, who currently works in an executive position for DuPont, was previously Deputy Administrator of EPA and EPA assistant administrator of the Office of Prevention, Pesticides and Toxic Substances. Before that, she had worked as vice president of Government Affairs for Monsanto. 2) Val Giddings is currently the Vice President for Food and Agriculture of the Biotechnology Industry Organization (BIO). Before joining BIO, Giddings worked within APHIS, serving on the US delegations that negotiated the Biodiversity Convention and represented the US at the United Nations Conference on Environment and Development Conference in Rio de Janeiro in 1992. 3) Richard Crowder was recently nominated US Trade Representative's Chief Agricultural Negotiator. His jobs before this appointment include senior positions with the American Seed Trade Association, a Washington lobby for the seed industry, and Dekalb Genetics, an agricultural biotechnology company now part of Monsanto.

A number of US states have supported GM foods and crops by passing bills on specific aspects of agricultural biotechnology. Bills supporting the use of GM foods have, for example, called for the banning of crop-destruction, or have expressed general support for biotechnology. The content of state bills tends to 
reflect regional interests. Measures that support agricultural biotechnology are usually passed by states with large farming sectors (Pew Initiative on Food and Biotechnology Legislation Tracker 2004).

US actors critical of GM food have engaged in some, but not continuous coordinated activity. Some actors, like Greenpeace and the Union of Concerned Scientists, tend to act on their own instead of with other groups, even though they may share compatible views and goals. Coordinated activity is usually on specific issues, and is often concentrated in individual regions of the United States. The US government and mainstream political parties in no way support GM food opponents' activities.

An important collaboration took place through the Genetically Engineered Food Alert, which was especially active in the late 1990s. Genetically Engineered Food Alert is a coalition of several organizations including US PIRG, Friends of the Earth, the Center for Food Safety, and the Organic Consumers Association. The focus of this campaign was a call for the labeling of GM foods, as well as to protest against GM foods produced by Kraft Foods ("Genetically Krafted Foods campaign"). A visibly successful campaign by US opponents of GM foods was the "Stop GM Wheat Campaign". Many of the above-mentioned actors participated in this campaign. Their efforts were rewarded when, in May 2004, Monsanto, anticipating a negative reaction from farmers and consumers, announced that it was dropping plans to commercialize GM wheat. While successful in influencing Monsanto's company policy, the company did not have an impact on federal regulation.

A further campaign worth mentioning, launched by the National Family Farm Coalition (NFFC), is the "Farmer to Farmer Campaign on Genetic Engineering" (National Family Farm Coalition Farmer to Farmer Campaign on Genetic Engineering). This network of US farm organizations seeks to build a farmer-driven campaign informing farmers of the risks of genetic engineering in agriculture. They focus on issues such as labeling, industry liability, and banning biopharmaceuticals in food crops.

The US Congress and several US states have proposed a series of bills on various issues regarding genetically modified food. By far the most active US 
congressman is Dennis Kucinich, a GM food skeptic from Ohio who ran in the 2004 Democratic presidential primaries. A member of the House of Representatives since 1997, Kucinich has introduced several versions of various bills questioning current US regulation of GM foods. His more recent bills include the "Genetically Engineered Food Safety Act" (US Congress, House of Representatives 2003b, introduced in 2003), which calls for amendments to the Federal Food, Drug, and Cosmetic Act which would make GM food approval obligatory and more stringent. A second bill is the "Real Solutions to World Hunger Act of 2003" (US Congress, House of Representatives 2003c, introduced in 2003), which prevents exports of non-authorized GM produce. A third noteworthy bill is the "Genetically Engineered Food Right to Know Act" (US Congress, House of Representatives 2003d, introduced in 2003), which calls for the labeling of GM food. A similar bill was introduced in 2000 by Senator Barbara Boxer (US Congress, Senate 2000). None of these bills came near to being passed or even voted on. Margaret Mellon of the Union of Concerned Scientist comments that

"the US Congress is out of the loop because of the White House's decision taken in the mid-1980s to pass no new laws on biotechnology. Some people in Congress are interested in the issue, but it's a non-starter to want to legislate against the will of the administration." (interview with Margaret Mellon, Union of Concerned Scientists, 9 June 2004, Washington, DC).

The 1986 Coordinated Framework has never been fundamentally questioned by state legislation (Pew Initiative on Food and Biotechnology Legislation Tracker 2004). Topics addressed have included labeling and liability, but also anti-crop destruction or the expression of general support for biotechnology, as mentioned above. State legislative initiatives have not led to any change in US federal policy on GM foods (as was indirectly the case for rDNA research), in stark contrast to the impact of European Union Member States. Most legislative initiatives are not passed, but serve to raise awareness and spark a debate. US States most active in raising contentious issues connected to GM foods and in questioning US federal regulations are California, Vermont and Maine. Examples of bills passed that show a critical stance towards current federal regulation include Maine's June 2003 bill imposing a civil violation for 
the false labeling of products as non-GM (Maine Legislature 2003), and Vermont's April 2004 bill requiring all GM seed to be labeled (Vermont Legislature 2004) (Pew Initiative on Food and Biotechnology Legislation Tracker 2004).

\subsection{Actors and actor coalitions in the European Union}

\section{EU actors and actor coalitions in favor of GM food and crops}

EU actors supporting GM foods and permissive regulation have been unable to render the EU's relatively restrictive policy more permissive. There are three main reasons for this. The first is that in the EU, there are fewer supportive actors than in the US, and that the supportive actors appear to be less convinced by the positions they advocate. The second is that these actors are only moderately united, both in terms of their goals and with regard to the story-lines they tell. Third, EU actors wanting to promote GM foods have had been confronted with hostile public opinion and a low level of trust in institutions in Europe, a result of several important shock events related to food safety.

Actors In the EU, the only consistent supporter of GM food is the agricultural biotechnology industry. Large farmers, and food processors and producers have taken an equivocal approach, offering neither clear support, nor outspoken criticism. The positions of farmers, and food processors and producers are discussed in this section, since their approach to agricultural biotechnology does not present an obstacle to GM foods. In addition, certain government actors - the European Commission and some Member States - have taken supportive stances towards GM foods. ${ }^{153}$

Key European agricultural biotechnology companies, all of which operate worldwide, are Bayer CropScience, a unit of the German company Bayer, and the Swiss company Syngenta. As explained above, the GM seed market is strongly linked with the pesticide market. Syngenta and Bayer control $17 \%$ of that market

\footnotetext{
${ }^{153}$ As in the case of the US, molecular biologists in the EU have not been very active in the debate surrounding GM foods and crops. When they have voiced their views, their opinions on GM foods have been as divided as those of other actors in the EU. Noëlle Vonthron confirms this impression: "In Europe, even scientists disagree on whether GM foods are safe or not" (interview with Noëlle Vonthron, EuroCommerce, 17 September 2004, Brussels).
} 
each, but share only roughly 12 to $20 \%$ of the GM seed market with DuPont, while Monsanto dominates 80-88\% of it (ETC Group 2005a, 2005b). At the EUlevel, they are represented by the European Association for Bioindustries (EuropaBio). Like their US counterparts, EU-based multinationals favor flexible regulation of GM products. Bernard Graciet of Syngenta summarizes their position well when he says that Syngenta welcomes legislation that "minimizes risks and is realistically applicable" (interview with Bernard Graciet, Syngenta, 15 June 2004, Brussels). As with US multinationals, these companies' resources are considerable, although EuropaBio, is a small organization in comparison to BIO in the US. ${ }^{154}$

Large-scale farms using intensive farming methods are less frequent in Europe than in the US. Large farms (by European standards) mainly growing grain exist in countries like Denmark, France, Germany, Spain and the UK. At the EU-level, this type of mainstream farmer is represented by the Committee of Agricultural Organisations in the European Union - General Confederation of Agricultural Co-operatives in the European Union (COPA-COGECA). This is a relatively large lobbying group, but again, Farm Bureau's staff in Washington, $\mathrm{DC}$ is larger, and its resources vaster.

Main food processors and producers are European-based multinational companies such as Nestlé (Switzerland) and Unilever (UK/Netherlands). The relatively small staff (as compared to GMA in the US) of the Confederation of the Food and Drink Industries of the European Union (CIAA) represents their interests in Brussels. For the case of the EU, food producers are discussed separately from food retailers, who have adopted more GM food-critical position. Governmental actors that are supportive, but sometimes reticent and inconsistent, are the European Commission, as well as certain Member States, although this can fluctuate a great deal with national political agendas and situations.

Positions and interests The regulatory goals of EU actors supporting agricultural biotechnology are more modest and less cohesive than those of US supporters. Aiming to sell its products and improve the image of GM foods in Europe, the biotechnology industry is the only constant and convinced supporter

${ }^{154}$ Simon Barber of EuropaBio notes that "EuropaBio is tiny. We are ten people and [BIO] are probably 100. Our budget for the green sector is less than a tenth of what theirs is" (interview with Simon Barber, EuropaBio, 16 September 2004, Brussels). 
of GM technology in the EU. The agricultural biotechnology industry points out the problems of what it perceives to be an illogical process-based regulatory system, but does not dwell on this point, instead formulating its position as a reaction to the regulatory status quo. The biotech industry's main focus is to limit the degree of restrictiveness imposed by current regulation, for example as regards labeling and traceability, as well as more recent issues like liability and coexistence. Overall, the industry encourages a regulatory framework which, for all its restrictiveness, is reliable and predictable and will facilitate product authorization. This goal is illustrated by one interviewee close to the biotechnology industry who prefers to remain anonymous:

"What we have at the moment is a lack of predictability within the regulatory process. It should be reasonably predictable whether your product can be approved or not. Approval should be science-based, but decision-making in this area has become entirely politicized".

Berhard Graciet of Syngenta voices similar discontentment:

"First, the issue was traceability and labeling of GM foods in connection with consumer choice. Now that those rules are in place, The European Commission has decided that GM crops cannot be grown without the regulation of coexistence, the details of which are to be defined by the Member States. When coexistence rules are in place, the issue of environmental liability is likely to be taken up. This is a very unstable and unpredictable regulatory environment for industry to deal with. Every time an obstacle for the new technology is overcome, a new one is put in place" (interview with Bernard Graciet, Syngenta, 15 September, Brussels 2004).

Large-scale mainstream farmers are more equivocal supporters of GM food and crops. They are neither ideologically opposed nor particularly enthusiastic about agricultural biotechnology. As Roxane Feller of COPACOGECA summarizes, "our position with respect to GMO is not very strong: we are neither for nor against GMOs" (interview with Roxane Feller, Committee of Professional Agricultural Organisations in the European Union and General Confederation of Agricultural Co-operatives in the European Union (COPACOGECA), 14 September 2004, Brussels). Furthermore, 
"COPA-COGECA has two principles with respect to GMOs: 1. To each his own responsibility: it is not up to farmers to decide whether GM crops and foods should enter the marketplace or not. 2. Each farmer should be able to choose what he grows and how he grows it" (ibid.).

Farmers in the EU thus support the principle of maintaining farmer and consumer choice by applying process-based rules and the precautionary principle when necessary, as well as by adopting an enforceable (i.e. not too strict) approach to labeling.

This relatively vague position is connected to the fact that the benefits that European farmers can expect from commercialized GM crops are not all that tangible. First, most European farms are not as large as the agribusinesses for which GM crops have been developed, thus reducing the potential benefit of high yields that usually occur through efficient cultivation of large expanses. Second, soybeans, a major GM crop, are hardly grown in Europe. Third, as discussed under paradigms, European agricultural policy has been increasingly rewarding farmers for taking land out of production, and emphasizing quality over quantity, whereas GM crops, in the European context, are not associated with quality. Fourth, interconnected with this point, European consumers appear to reject GM crops and foods. This rejection has traveled up the food chain, from consumers to retailers to producers and processors, and finally to farmers and even to the biotechnology industry. If EU consumers do not want to eat GM foods and they do not present a significant advantage for farming, why should farmers plant them? ${ }^{155}$

True to their pragmatic and somewhat ambiguous approach to GM foods, EU food industries tend to orient their policies toward consumer preferences. This is summarized for the case of Nestle by Guido Kayaert who states that his company's

"position is that the use of biotechnology is acceptable if GM products are safe, and if this approach can be communicated properly to the

${ }^{155}$ The only country to plant GM crops commercially in the EU is Spain. 12\% of the corn grown in Spain is Bt corn (about 58.000 hectares), used mainly for animal feed (TransGen 2005a). Bt corn is a reasonable choice for Spanish farmers in the northeastern and central Spanish regions of Aragón, Castilla-La Mancha, and Cataluña, where the European corn borer is widespread. 
consumer. The underlying principle is self-responsibility" (interview with Guido Kayaert, Nestlé, 6 September 2004, Brussels).

In the mid-1990s, food industries opposed labeling and supported the use of GM ingredients in processed food. In the late 1990s, however, when it became clear that the EU public might not accept GM food easily, they adopted a more reticent if still basically supportive position. Food industries advocate a policy that is permissive enough to allow for innovation, and restrictive enough to give consumers and industry alike the option to choose between GM and non-GM food. They support labeling with a "realistic" threshold, that is a threshold that industry will be able to apply relatively easily and at as low a cost as possible. Dominique Taeymans of the Confederation of the Food and Drink Industries of the European Union (CIAA) explains that

"the main problem for CIAA members is the issue of GM food labeling [...]. It is CIAA's policy to try to avoid overly strict labeling regulations. Our view is that labeling leads to unfair stigmatization of a product" (interview with Dominique Taeymans, Confederation of the Food and Drink Industries of the European Union, 7 September 2004, Brussels).

Instead of going overtly "GM free" as retailers have, food industries producing for the EU market generally circumvent the GM ingredient problem by reformulating the recipes of their products to not contain GM ingredients, or by ensuring that individual GM ingredients stay under the adventitious presence threshold of $0.9 \%$.

The positions of the European Commission and EU Member States supporting GM foods are conditioned by the dual goal of increasing the continent's international competitiveness while protecting consumer health and the environment. As explained in Chapter 6, the European Commission has always aimed to develop regulations that would both stimulate growth and competitiveness and offer consumers and the environment adequate protection. Much the same regulatory goals can be found in individual supportive Member States. Their regulatory aim is thus to strike a balance between these two potentially contradictory goals. Member States' positions and internal political situations are reflected by the Council of Ministers' voting records on the authorization of individual GM products. 
Specific reasons for promoting GM foods are rooted in national research and industry traditions in biotechnology that began to develop in the 1980s. For example, the Netherlands has made significant investments in biotechnology since the 1980s, and wants to capitalize on them (Gutteling et al. 2001). ${ }^{156}$ Similarly, in Finland, biotechnology became firmly established both in academia and business in the 1980s, and is thus considered a strategic sector (Rusanen et al. 2001). In the UK, a country with a similarly strong tradition in biotechnology research and applications, there exists a tradition of pragmatic and case-by-case policy-making, which was shaken somewhat when the GM food controversy surfaced (Gaskell et al. 2001). Some countries have been supportive in the past, but have pulled back from that position for political reasons. For example, Spain, the only EU country cultivating GM crops commercially, has been generally supportive, but recently has abstained from voting on controversial authorizations since the 2004 national election produced a new center-left majority in parliament and government. Other examples are France and Belgium, which have reviewed their supportive stance somewhat due to pressures from civil society.

Story-lines The story-line told by GM food proponents in the EU is less cohesive than is the case in the US. While EuropaBio's story-line is similar to that told by its US counterpart BIO, narratives by farmers and the food industry are more cautious and less confident.

EuropaBio tells a story of a technology based on sound science, and of a technology with the potential to greatly benefit the environment. Despite presenting the same types of arguments in favor of GM plants and foods, EuropaBio comes across as somewhat more defensive than BIO (EuropaBio Frequently asked Questions about Plant Biotechnology). Its slogan, "The Voice of the European Bioindustries", is more neutral, and much less strident and ideological than that of BIO ("Partner to a Dynamic Industry Coming of Age"). EuropaBio seems to expect that EU citizens will not be as easily convinced as US citizens by the potential benefits of biotechnology. In its fact sheet on "green

\footnotetext{
${ }^{156}$ Oscar Meuffels of the Permanent Representation of the Netherlands to the EU further explains that the Netherlands have been supportive of agricultural biotechnology since its introduction, a position connected with a tradition of research in this area, the importance of the agricultural biotechnology industry in the Netherlands, as well as with the Dutch people's relatively nonemotional relationship with food (interview with Oscar Meuffels, Representation of the Netherlands to the EU, 17 September 2004, Brussels).
} 
biotech", the organization seems to feel obliged to refer to Europeans' negative public perception of biotechnology - possibly a result of "confusion with other food scares" - and their "lack of trust in the regulatory system" (EuropaBio Green Biotech). EuropaBio tries to convince European citizens that scientifically sound and rigorous safety assessments conducted by independent government experts, and following international standards ensure safety in the field of agricultural biotechnology. All in all, EuropaBio conveys the impression that it is mainly concerned with "saving what there is to be saved".

The story-line told by the Committee of Agricultural Organisations in the European Union/General Confederation of Agricultural Co-operatives in the European Union (COPA-COGEGA), the organization representing EU mainstream farmers, is bland and pragmatic, a striking contrast to Farm Bureau's fiery rhetoric (Committee of Agricultural Organisations in the European Union/General Committee for Agricultural Cooperation in the European Union 2000) "Freedom of choice" is the only element that Farm Bureau's and COPACOGECA's story-lines have in comon, and yet they mean different things by that phrase. While Farm Bureau is referring to the right to choose GM crops, COPACOGECA is referring to farmers' freedom to choose between the use of GM crops and non-GM crops. COPA-COGECA does not oppose GM crops and food on principle and its feelings toward agricultural biotechnology are clearly ambivalent. Its position is that precaution is necessary in the face of scientific uncertainty. It also voices support for publicly funded research instead of research conducted by private industries. In particular, it advocates public research on the possible consequences of GM food for human health and the environment. It also calls for a wide public debate on GM foods. The story-line told by COPA-COGECA contains a pragmatic dimension: agricultural biotechnology is here to stay. Whether it ends up being particularly beneficial or not, European farmers and citizens alike should be in a position to make informed decisions.

Like its US counterparts (GMA and FPA), the Confederation of the Food and Drink Industries of the European Union (CIAA) promotes free market values, but its story-line is far less ideologically motivated. In the context of European consumer rejection of GM food, CIAA advocates industry's right to choose between the use of GM and GM-free foods and food ingredients, a 
responsible use of agricultural biotechnology, and maintaining consumer confidence. It tells a somewhat colorless story of the trouble that European food industries face trying to avoid using GM foods and ingredients altogether. CIAA further stresses that "industry is convinced that a responsible use of biotechnological developments would benefit all actors of the food chain". The only reason why CIAA promotes process-based regulation and labeling is that the European consumer might otherwise reject the food industries' products. It fears that the recently updated EU labeling rules will create a sizable administrative burden. From CIAA's point of view, the old and less rigorous labeling rules served the food industry well: they kept administrative costs relatively low while keeping the consumer satisfied.

As documented in Chapter 5, the European Commission has gone to great trouble to promote biotechnology starting in the 1980s (Nollert 2000, Abels 2002). It has assigned biotechnology research and development the main role in closing a perceived technological gap between Europe and the United States. At the same time, the late 1990s saw a shift towards precaution, and towards the need to understand and address European citizens' skeptical approach towards science and technology.

In response to this skepticism, in its "White Paper on Governance", the Commission emphasizes the need to "[b]uild public confidence in the way policy makers use expert advice" by opening the decision-making process to greater public scrutiny and debate (European Commission 2001: 19, 33). Its recent strategy document entitled "Life sciences and biotechnology - A Strategy for Europe" (European Commission 2002) reiterates Commission support for biotechnology by stating that "Life sciences and biotechnology are widely recognised to be, after information technology, the next wave of the knowledgebased economy, creating new opportunities for our societies and economies". It specifically underlines that in "the agro-food area, biotechnology has the potential to deliver improved food quality and environmental benefits through agronomically improved crops". The Commission's solution to public rejection of biotechnology and especially GM foods includes "societal dialogue" and respect for "ethical values and societal goals" (European Commission 2002: 11). In summary, the European Commission has remained supportive of GM foods, 
while at the same time trying to widen its acceptance through improved methods of "governance" $"$.

Some have analyzed this shift as a new, necessary focus on "input legitimacy", i.e. rendering the decision-making process more representative and accountable, in addition to the already developed "output legitimacy", based on performance and expertise (Abels 2002, Landfried 1998 ${ }^{158}$, Skogstad 2003, von Schomberg $1998^{159}$ ). According to Skogstad, "the EU faces a dual legitimation imperative $[\ldots]$ in policy areas, like genetic engineering, of declining authority of unaccountable experts and deep societal cleavages over public policy goals" (Skogstad 2003: 334).

From the perspective of critics of GM foods, the Commission is indeed biased in favor of agricultural biotechnology. For example, Éric Gall of Greenpeace's European Unit states that "the European Commission is very proinnovation [...] and tries to push GMOs onto the market whenever it has the opportunity" (interview with Éric Gall, Greenpeace, 13 September 2004, Brussels). ${ }^{160}$

Similarly to the Commission, Member States supportive of GM foods emphasize the need to fully utilize the potential of biotechnology while providing citizens with adequate protection. In the late 1990s, these countries generally switched from a policy of simply promoting modern biotechnology as part of public policy and seeing it as a tool for future R\&D to creating more possibilities for involving the public and recognizing the need to address ethical and social

${ }^{157}$ The Commission's White Paper on Governance defines governance as "rules, processes and behaviour that affect the way in which powers are exercised at the European level, particularly as regards openness, participation, accountability, effectiveness and coherence (European Commission 2001: 8). For example, it is in the name of governance that the Commission took what could be defined as a consumer-friendly position in the 2003 regulations of GM food and feed, and on labeling and traceability.

158 Landfried does not use the term "input legitimacy", but her call for "communicative knowledge" in the area of genetic engineering policy is a comparable concept.

159 Von Schomberg calls for a "discursive" policy process, which follows "the logic of [...] uncertainty", and which can therefore be "flexible [...], effective and legitimate" (von Schomberg 1998: 125, 135).

${ }^{160}$ Gall adds that "the fact that there is a strong lobby by the biotech industry and strong pressure from the United States also explain the Commission's stance on GMOs. It has, however, been pushed in other directions by public opinion and by some EU Member States" (interview with Éric Gall, Greenpeace, 13 September 2004, Brussels). 
issues (Gutteling et al. 2001, Rusanen et al. 2001, Gaskell et al.). Simon Barber of EuropaBio sees this shift as

"a phenomenon of total schizophrenia in Europe, in which the Council starts out emphasizing the Lisbon agenda ${ }^{161}$, and then individual Member States or individual ministers of Member States sabotage the effort" (interview with Simon Barber, EuropaBio, 16 September 2004, Brussels).

\section{EU actors and actor coalitions against GM foods and crops}

Actors and the coalition of actors opposing agricultural biotechnology in the EU have been very successful in achieving many of their policy goals. Since the EU first passed legislation on GM foods, they have been able to obtain more restrictive rules, for example in the areas of labeling and traceability. One of the reasons for this success is that EU actors opposing GM foods have pushed for common goals throughout. Furthermore, the coalition is relatively strong because it includes important actors that the US coalition does not. Finally, anti-GM food actors and actor coalitions found fertile ground for their anti-GM agenda in Europe, where a series of much-publicized shock events consolidate the European public's distrust in its regulatory institutions.

Actors EU actors opposed to GM foods are small-scale and organic farmers, food retailers, consumers, environmental groups and green parties, both at the European and national levels. Small-scale and organic farmers are represented by European Farmers Coordination (CPE, Coordination Paysanne Européenne) at the EU-level, an organization that consists of farmer and rural organizations that radically oppose any introduction of GM crops and foods into the food chain. CPE members include José Bové's Confédération Paysanne. Small retailers operate on a national level while large retailers may be present in more than one country. They are represented by EuroCommerce at the EU-level. Examples of large retailers are Carrefour in France, Metro in Germany, Royal Ahold in the Netherlands, and Tesco in the UK. European Consumers are represented by the European Consumers' Organisation (BEUC, Bureau européen

${ }^{161}$ In 2000, at the Lisbon European Council (summit meeting of heads of state and government of EU Member States), European leaders committed themselves to making the European Union "the most dynamic and competitive knowledge-based economy in the world" by 2010 (European Council 2000). 
des consommateurs). Key environmental groups are Greenpeace and Friends of the Earth. Green parties are generally opposed to GM food; examples are the European Greens (consisting of Member State green parties) and the European Free Alliance (consisting of green parties from European regions described as "stateless nations", such as Scotland or the Basque Country). Together, these make up the European Parliament's "European Greens - European Free Alliance". Particularly supportive and active national green parties include Bündnis 90/Die Grünen (Germany), Les Verts (France), and ECOLO and Groen! (both from Belgium).

An important difference between the EU and the US is that in the EU, non-governmental actors that are not funded by industry tend to receive support from governmental institutions. For example, almost one third of Friends of the Earth Europe's budget consists of financial support from the European Commission's Environment Directorate-General, and another 4\% comes from national environmental ministries, whereas Friends of the Earth USA does not receive financial support from government (Friends of the Earth Europe About Us, Friends of the Earth USA 2004: 13) ${ }^{162}$ Greenpeace Europe, however, has a policy of not accepting donations from governments, corporations or political parties.

Governmental and non-governmental EU actors opposed to GM foods are strongly united in their quest for ever-stricter process-based regulation of GM foods based on the precautionary principle. They have called for and obtained more stringent labeling rules, as well as a traceability regime. They are now pushing to make other areas of regulation more restrictive, in particular, liability, coexistence and adventitious GM presence in seed.

Positions and interests These actors' interests in restrictive regulation are slightly different, but all lead to the same basic position and policy goals. Small and organic farmers' interest is to expand support and markets for the kind of farming that they depend on for their livelihood: non-intensive farming, based on principles of sustainability and quality instead of low cost and quantity. EU retailers' support for restrictive regulation, on the other hand, is directly linked to

\footnotetext{
${ }^{162}$ Nevertheless, Friends of the Earth USA's revenue is more than thee times that of Friends of the Earth Europe.
} 
consumer preference. They wish to be able to sell non-GM foods since that is what the consumer wants to buy. As in the US, consumers are interested is the right to choose between GM food and non GM food, as well as the protection of their health, and consumer organizations have a stake in representing these interests in order to operate successfully. Like in the United States, environmentalists' objective is to protect the environment. Their interest in seeking restrictive GM food regulation is also in maintaining and increasing public support, trust and therefore membership and financial contributions. Parties and governmental actors opposed to GM foods have an interest in representing the views of their members and electorate.

Story-lines EU actors critical of GM foods are united by a story-line that is similar in many ways to the narrative of critical actors in the US, but one which is stronger and more successful. Some of its more extreme elements are not shared by EU retailers, most consumers or government actors. This has not been an obstacle, however, for the development of a thriving discourse coalition.

All of the actors involved believe that genetic engineering is a fundamental departure from conventional breeding, which, in the words of BEUC, "will change the nature and scale with which humanity is able to intervene with genetic processes" (European Consumers' Organisation 1996). A common theme is that GM foods and crops may cause hazards to health and the environment, as well as a strong belief that consumers have a right to be informed and to choose between GM foods and non-GM foods through labeling. One interesting if subtle difference with the US is that BEUC often describes consumers as citizens, thus framing consumer rights as political rights. A further point often raised by critics is that the European Commission has too much power in dealing with the GMO dossier, considering that it is only a bureaucracy, which is not democratically elected.

A noteworthy difference is between actors that firmly condemn GM foods as a product of a global economic system emphasizing production and profit irrespective of the impact on the environment (CPE, Greenpeace, Friends of the Earth, some green parties), and actors who do not focus on these aspects because they are more concerned with consumers (BEUC, EuroCommerce, governmental actors). While the former seek a wide debate on all possible risks of genetic 
engineering, the latter focus on consumer choice through labeling, and are generally more open to compromise.

European Consumers' Organisation (BEUC) points out that the "last five years have shown that GM food will never be accepted in Europe without consumer choice" (European Consumers' Organisation 2002). Therefore, Beate Kettlitz of the BEUC states that "the content of BEUC's campaign on labeling GM foods was to give the consumer a choice" (interview with Beate Kettlitz and Patrick Sutton, European Consumers' Organisation, 14 September 2004, Brussels). However, Kettlitz specifies that "we should not enter a course of rejecting everything" and that "BEUC agrees with the idea of a threshold because a 'no GMO' policy is not realistic" (ibid.). ${ }^{163}$ As a result, consumer groups are satisfied with the 2003 EU regulations which introduced stricter labeling rules and the concept of traceability. Kettlitz is of the opinion that "In Europe, a robust approval system is [now] in place. Europeans basically trust the approval system $[\ldots] "$ (ibid).

As has been noted above, seen from the point of view of GM food supporters in Europe, food retailers represent a decidedly weak link in the campaign to encourage the acceptance of GM foods. Noëlle Vonthron of EuroCommerce explains that "EuroCommerce members changed their policy on GM food as a result of a wave of rejection by consumers towards the end of the 1990s". More specifically,

"on the GM food dossier, EuroCommerce members took a consumeroriented approach, because commerce is the closest link between industry and the 450 million consumers in Europe. When retailers recognized that consumers did not want GMOs in their food, they decided to follow that trend. That does not mean that they will not market foods containing GMOs at all, but for their own-brand products they have a clear non-GMO policy" (interview with Noëlle Vonthron, EuroCommerce, 17 September 2004, Brussels).

${ }^{163}$ An important part of BEUC's position is that GM content should only be adventitious, i.e. accidental, because this signals that producers have decided to go for non-GM production and that, as a default, they try to preserve the identity of the product. 
In contrast to consumer groups, environmental groups condemn genetic "contamination" in a broader sense. Geert Ritsema and Carmen Olmedo of Friends of the Earth Europe confirm that their organization

"has a different position than some consumer organizations such as BEUC on the GMO issue. While BEUC reduces the issue to consumer choice and labeling of GM foods, Friends of the Earth Europe goes further by asking: 'do we really need to grow GMOs?'” (interview with Geert Ritsema and Carmen Olmedo, Friends of the Earth Europe, 3 September 2004, Brussels).

Greenpeace GMO Policy Advisor Éric Gall illustrates this wider-ranging approach in a description of the reasons behind Greenpeace's campaign against GMOs:

"the primary reason for Greenpeace's campaign against the release of GMOs in the environment are the potential irreversible impacts of GMOs on the environment and on health. [...]. Secondly, GMOs have been a tool to impose strong intellectual property rights on genetic resources $[\ldots]$, for the benefit of multinationals and agribusiness, and at the detriment of farmers and public research. [...] Thirdly, GMOs are the ultimate step of industrial agriculture, which destroys farmers and the environment around the world [...]" (interview with Éric Gall, Greenpeace, 13 September 2004, Brussels).

Despite these differences in approach, in the European case, a strong and successful story-line has emerged, which blends the condemnatory anti-corporate tone of environmental groups with consumers' and detailers' demand for choice. Éric Gall of Greenpeace is convinced that the anti-GM food movement goes against more than just GM foods:

“The GMO debate helped open European citizens' eyes on how their food is produced; many feel that the industrialization of agriculture and food production has gone too far" (interview with Éric Gall, Greenpeace European Unit, 13 September 2005, Brussels). 
In connection with the shock events that alarmed Europeans, the anti-GMO story-line bound together the European public, thus becoming generally accepted as a truthful description of the situation surrounding GM food.

It is not surprising to note that industry denounces this story-line and the coalition behind it. For example, EuropaBio's Simon Barber declares the following:

"My view is that much of this is an NGO-made issue that probably would not have arisen if the NGOs had not chosen to make it an issue. I don't think the average consumer would have been concerned at all. [...] If someone devotes enough money to frightening people about a certain issue, then they will get frightened" (interview with Simon Barber, EuropaBio, 16 September 2004, Brussels).

A further perspective comes from Karil Kochenderfer of Grocery Manufacturers of America in the US, who contends that European NGOs tell only half the truth about GM foods:

"European NGOs underline future risks, but do not mention the present lack of risks. GM foods are probably the most well-examined global products that we've ever seen" (interview with Karil Kochenderfer, Grocery Manufacturers of America, 17 June 2004, Washington, DC).

Bernard Graciet of Syngenta is more congratulatory, but essentially points out that NGOs carefully construct their agendas with the goal of public success:

“I must congratulate environmentalists' professionalism. They are extremely active and efficient. The lobbying done by multinational companies is much less successful than the organization of civil society by environmental groups" (interview with Bernard Graciet, Syngenta, 15 September 2004, Brussels).

\section{Shock events}

The series of shock events in Europe chronicled in Chapter 2 that coincided with the development and marketing of biotechnology has helped actors opposing GM foods and favoring restrictive regulation achieve their policy goals, and has made it very difficult for GM food supporters to realize theirs. 
An event that caught not only the world's attention, but also their imagination was the news, announced in February 1977, that a cloned sheep named Dolly had been born in July 1996 in the United Kingdom (UK). In the minds of European citizens, this event symbolized the beginning of a new era in which scientists could clone mammals and had therefore seemed to have gained control over creation itself. Europeans were not necessarily comfortable with this new prospect.

The shock event with the most profound repercussions was Bovine Spongiform Encephalopathy (BSE) or "Mad Cow Disease". Around the time that the first GM crops were being planted and harvested, the BSE crisis reached its high point. In 1995, the first case of a new variant of Creutzfeldt-Jakob disease (vCJD), a disease in humans resembling BSE, was diagnosed in the UK, and in March 1996, the UK government announced that there appeared to be a link between BSE and vCJD. The EU reacted by imposing a worldwide ban on UK cattle and beef exports. Although the probable causes of BSE are completely unrelated to genetic engineering and GM food, the UK public and the EU public in general made a connection between BSE with GM foods. In both the cases, intensive farming and industrialization of the farming and food industries were seen as the culprits. In both cases, regulators were perceived as having failed in their responsibilities, and as having important concealed information from the public. It is a commonly held view that "BSE appeared, at least around 1999, to be the leading reason [...] for skepticism over GM food" (Toke 2004: 63). Jasanoff does not treat BSE as the single cause for rejection of GM food, but does note that it "is hard to disentangle the story of opposition to GM foods in Britain in the late 1990s from the still unfolding story of BSE" (Jasanoff 2005: 121). ${ }^{164}$

Further shock events pertaining to GM foods that compounded the effects of the BSE affair were public outrage over "terminator" technology, and the release of Puzstai's experiments feeding GM potatoes to rats. The May 1999 discovery of high levels of dioxin in chicken and egg products in Belgium only

\footnotetext{
${ }^{164}$ In the UK, a further blow was dealt to agricultural biotechnology by Prince Charles, who, in June 1999, expressed his doubts about GM foods in the Daily Mail. In this article, he raised a number of questions that went beyond health and the environment, including "do we need GM food in this country?" and "what sort of world do we want to live in?". He judged that that "the public's reaction shows that we are nervous about tampering with Nature when we can't be sure that we know enough about the consequences" (Windsor 1999).
} 
made matters worse. This shock event related to food safety but did not involve genetic engineering or GM food. A factor aggravating this episode in the public consciousness was the fact that Belgian authorities became aware of a possible problem in late April 1999, but did not inform the public until one month later.

In Europe, such shock events incited or at least consolidated negative public opinion with respect to GM foods and crops, although they were not directly necessarily connected to the genetic engineering of foods. This rejection of GM foods, that began in the late 1990s and remained into the present, has become part of a mainstream view on GM foods in many European countries. As one interviewee who asked to remain anonymous noted,

"with the benefit of hindsight, the trouble was that GM technology was perceived as something new and mysterious for the public, which led to consumer concerns about being involuntarily exposed to risk. In the view of consumers, this is not like smoking or driving, which involve voluntarily risk taking. [...] people feel a lack of control."

A recent "Eurobarometer" on biotechnology confirms that "a majority of Europeans do not support GM foods"; In 2003, actual support for GM foods existed in only four countries: Spain, Portugal, Ireland and Finland (European Commission 2003: 1-2). The Eurobarometer notes that public support began declining after 1996, when first GM products began to be commercialized, and after vCJD had appeared. A 2005 Special Eurobarometer on "Europeans, Science and Technology" confirms the trend: $54 \%$ of Europeans think that GM food is "dangerous", 23\% neither agree nor disagree, and only 14\% disagree (European Commission 2005c). It is important to note that there are important differences among Member States, often reflected in Member State government positions. In Cyprus, Austria and Greece, 70 to $90 \%$ of citizens believe that GM foods are dangerous against 30 to $40 \%$ in the Netherlands and Finland (ibid.).

As a result of BSE and other crises, many Europeans mistrust not only industry, but also their regulators. In 1999, Cantley et al. noted that in "Europe, the public's faith is in consumer and environmental organizations rather than in governments, industry, or academia" (Cantley et al. 1999: 38). The 2003 Eurobarometer found that 55\% of Europeans trust the European Commission, and that less than $50 \%$ have confidence in their own government and in industry 
(European Commission 2003: 3). Actors supporting GM food are critical of regulators' failure to react in a more convincing manner. For example, Simon Barber of EuropaBio states that:

"if citizens are fed all sorts of scary stories, especially after there have been real scares, they can become worried. I'm disappointed that regulatory authorities and governments did not do more to tell people about the history of safety assessment of agricultural biotechnology. It is a shame that governments did not stand up and support their regulatory decisions" (interview with Simon Barber, EuropaBio, 16 September 2004, Brussels).

In conclusion, shock events, especially BSE, were very important for the success of EU actors and actor coalitions opposed to GM food. GM proponents had little hope of convincing Europeans that GM foods were good for the environment and had nothing to do with BSE. For Europeans, the marketing of GM foods was just one more food issue that their governments, at EU and national levels, had not dealt with adequately, since GM foods seemed to have found their way into Europe without citizens being informed. Birkland suggests that what he calls a focus event, which is a specific type of shock event, "is more likely to be focal if an interest group or groups are available to exploit the event in their quest for policy change" (Birkland 1998: 72). Indeed, the anti-GM food coalition was able to pick up on and very effectively exploit the resentful and fearful mood resulting from the series of shock events very effectively in its push for increasingly restrictive GM food policies (e.g. Ansell et al.).

\section{Activity and impact on policy}

EU actors for and against GM foods have both acted alone and collaborated in a number of ways. Positions, story-lines and methods are not that entirely cohesive in either one of these camps.

Within the EU, stakeholder organizations supporting GM food have found it more difficult than their US counterparts to engage in coordinated activity. Due to their different interests, cooperation among actors throughout the food chain, as 
takes place both formally and informally in the US, is weak to non-existent among EU actors. Actors tend to act alone rather than as part of a coalition.

Some cooperation has developed among individual biotechnology companies, in the form of common promotion and educational events, for instance, joint sponsorships of conferences and debates. One example is "BioVision", the so-called "World Life Sciences Forum" held yearly since 1999, and supported financially by numerous US and EU biotechnology companies, as well as the European Commission.

In the mid 1990s, some of the actors supporting GM foods disagreed on how best to make GM foods known to and accepted by the public. From interviews and secondary literature, it appears that Monsanto was criticized by potential allies in Europe for its lack of cooperation. For example, Guido Kayaert of Nestlé recalls that

"European food industries received only a brief advance warning that Monsanto was going to send its first shipments of GM grain to Europe. This event took us [within the food industry] by surprise and did not leave any time to inform and educate the public. This caused some annoyance among European industries" (interview with Guido Kayaert, Nestlé, 6 September 2004, Brussels).

Similarly, Dominique Taeymans of the Confederation of the food and drink industries of the European Union feels that

"the biotechnology industry communicated poorly in 1995-96. That is one of the elements that led to the public's negative reaction to GMOs. The public was shaken at the same time by the BSE crisis in Europe, and these elements together led to a crisis of public trust in institutions" (interview with Dominique Taeymans, Confederation of the food and drink industries of the European Union, 7 September 2004, Brussels).

Monsanto seems to also have irritated European-based agricultural biotechnology companies, who felt that the US company was taking an arrogant and irresponsible approach to entering the European market, seeing it as identical to the US market, and without listening to European industries' advice. This amounted to a "very St. Louis [the home of Monsanto Headquarters] attitude that 
Europe didn't really matter" (Linda Fisher, who worked for Monsanto at the time, quoted in Charles 2001: 210). EuropaBio became active in the biotechnology debate only around this time, too late to contribute to achieving the level of public acceptance necessary prior to the arrival of GM crops in the mid-1990s.

EU actors against GM foods diverge to some extent on the methods they use. While environmentalists and critical farmers are sometimes ready to employ radical activist tactics such as burning test fields or stopping ships transporting GM grain, consumer-oriented groups and government actors are not. Because of actors' different focuses, collaborations usually take place among several environmental groups, or several consumer-oriented actors. Greenpeace's European Unit suggests that environmental and consumer groups were also competing for the very issue of GMOs:

"In terms of cooperation with other actors on the GM food and crop issue, Greenpeace and environmental groups generally experienced some trouble with consumer groups, which were not happy that what they regarded as their territory was being trampled on" (interview with Éric Gall, Greenpeace European Unit, 14 September 2004, Brussels).

In 1998, European retailers initiated a collaboration that gave GM food proponents a particularly harsh blow. After it had become clear that European consumers strongly preferred GM free products, Iceland, a UK supermarket, went "GM-free". In March 1999, several other major European retailers, including Carrefour (France), Delhaize (Belgium), Esselunga (Italy), Marks \& Spencer (UK), Migros (Switzerland), Sainsbury's (UK) and Superquinn (Ireland) joined suit by forming a consortium committed to eliminating GM ingredients from their own brand products. Other retailers (for example Auchan (France), Coop (Italy), and Tesco (UK)) and chain restaurants (e.g. Burger King and Kentucky Fried Chicken in the UK) have since followed in the steps of this consortium, thus exercising considerable pressure up the food chain, first and foremost on food producers, and processors who are the retailers' suppliers. As mentioned above, food producers have not joined against GM foods as retailers have, but have found ways to quietly work around the problem which, for farmers and biotechnology companies, means lower demand for GM foods. As has been explained previously, this decision by major retailers in Europe presented a 
problem for food producers, especially large ones that engaged in voluntary labeling. Guido Kayaert recounts Nestlé's situation and its opinion of the retailers' move:

"The main problem for [Nestlé] arose when certain retailers, especially in the UK, decided to ban GM products from their shelves. We were one of the few companies that labeled voluntarily, so we were one of the only ones to be kicked off the shelves. Retailers' decision to go 'GM-free' was not a safety decision, but a commercial move" (interview with Guido Kayaert, Nestlé, 6 September 2004, Brussels).

Some environmental and farmer groups have adopted various forms of activism. Aside from numerous demonstrations and letter-writing campaigns, they are particularly renowned for their direct protest actions, some of them at odds with the law. For example, since late 1996, when first exports of GM crops were transported from the US to Europe, Greenpeace has been famous for blocking and delaying the entry of ships transporting GM soy and corn into major European ports such as Amsterdam, Rotterdam, and Antwerp. Protesters have also been known to disrupt the production, transportation, and distribution of GM grain by storming plants, transport equipment, and supermarkets, often dressed up as GM food and feed debate-related animals (chickens, cows, butterflies) or vegetables (tomatoes, corn cobs) to attract attention and underline the potential effects of GM foods.

A further widespread form of protest has been the destruction of GM crop test fields. Jose Bové's Confédération Paysanne, part of CPE, as well as national sections of Greenpeace and Friends of the Earth, have been known to damage test fields in several European countries including Belgium, France, Germany, and the UK. These included test sites that were part of the UK government's Farm Scale Evaluation ${ }^{165}$.

These groups have also extensively used the strategy of spreading and collecting information on GM foods and crops in Europe. Examples are

165 The Farm Scale Evaluations were a three-year program (2000-2003) run by the UK government's Department for Environment, Food and Rural Affairs to assess the environmental impact of herbicide tolerant corn, sugar beet, and oilseed rape in terms of biodiversity. To date, it is the most comprehensive study of its kind worldwide. Results of the study were mixed: while GM rape and beet cultivation seemed to have a negative impact on biodiversity, GM corn appeared to improve biodiversity in comparison with conventional corn. 
Greenpeace International's “Trolley Watch”, which encourages European consumers to report labeled GM foods in European supermarkets to a specific website (Greenpeace International Trolley Watch) and the "GM Contamination Register" set up by Greenpeace International and GeneWatch UK (Greenpeace International/GeneWatch UK GM Contamination Register) to record all incidents of "contamination" through the release of genetically modified organisms, that is the unwanted and unplanned presence of GM varieties among non-GM crop varieties.

The European Parliament's role in the GM food debate has been to form a counterbalance to the relatively supportive European Commission. A key participant in the legislative processes leading towards the main directives and regulations on GMOs and GM foods, the European Parliament has a track record of requesting more stringent rules and regulations than suggested by the European Commission. Examples of issues it has been especially attentive to include the threshold for the labeling of GM foods, as well as the explicit mention of the precautionary principle. The European Parliament can also send signals through resolutions. For example, the Parliament used this possibility in December 2003 by passing a resolution on "Coexistence of GM crops with conventional and organic plants", in which it called for "uniform and binding rules" on this issue (European Parliament 2003, art. 3).

Of course, the legislative story of each directive and each regulation is complex. The 2003 regulations, for example, are relatively stringent not only due to the European Parliament, but also as a result of the Commission's relatively consumer-oriented proposal, made in the name of a more transparent and accountable decision-making process. MEP Karin Scheele recalls that "in the case of the 2003 regulations, the European Commission put forward a progressive and consumer-friendly proposal, which led to a strongly polarized debate in the European Parliament. Although the largest parliamentary group was opposed to the reforms proposed, we were successful in putting together a majority in favor of the Commission proposal" (interview with Karin Scheele and Sigrid Semlitsch, European Parliament, 7 September 2004, Brussels).

Member States that have frequently presented a hurdle to GM foods are Austria, Denmark, Greece, and Luxembourg. Voting patterns in some other 
Member States, including France, Germany, Italy, and Spain, have changed frequently and have included abstention. These positions are usually connected to internal political situations. For example, from 2001 to 2005, the German Federal Ministry of Consumer Production, Food, and Agriculture was headed by Minister Renate Künast, a Green Party member who pushed for a restrictive Genetic Modification Act implementing EP and Council Directive 2001/18 in Germany, and against new GMO adoptions at the EU level. Not all members of the government were necessarily in agreement with this line, and the result of this national deadlock was a series of abstentions on votes concerning new authorizations.

Furthermore, Member States have the possibility to express their views and influence GM food policy through the safeguard clause contained in GM food policy. As described above, this clause provides the possibility for a Member State to "provisionally restrict or prohibit the use and/or sale of that GMO as or in a product on its territory" if it has detailed grounds to believe that it may be harmful to health or the environment" (Dir. 2001/18, European Parliament/Council of the European Union 2001, article 23).

\subsection{Conclusion}

As suggested by proposition 3, in the US, actors and actor coalitions supporting GM foods are stronger than those opposing GM foods, and have successfully pushed for permissive regulation of GM foods and crops. In contrast, in the EU, actors and actor coalitions opposing GM foods are stronger than those supporting GM foods, and have succeeded in obtaining restrictive GM food and crop policies. The empirical evidence presented in this chapter shows that the types of coalitions that actors form are important. For example, US actors in favor of GM foods and crops form both a successful advocacy coalition and a strong discourse coalition. Their counterparts, on the other hand, form only weak advocacy and discourse coalitions. In addition, empirical study of US actors supporting GM foods suggests that it is important to consider how many actors are involved, whether the whole food chain is represented, whether support from governmental actors exists, and what impact shock events have had. The main findings of this chapter are summarized below in Table 16. 
Pro-GM food coalitions consist of comparable actors in the US and the EU, but the US coalition is more cohesive and more strongly convinced of its mission than its EU counterpart. In the US, actors throughout the whole food chain, as well as regulators, support or at least do not oppose agricultural biotechnology. Stakeholders form an advocacy coalition united by common regulatory goals and successfully engage in coordinated activity. All supportive actors, including regulatory agencies, are bound by a strong common story-line about GM foods. US actors supporting permissive regulation have benefited from the lack of devastating shock events and from generally uncritical public opinion. The fact that Americans place greater trust in their regulatory institutions than Europeans is of further assistance to actors favoring GM foods. In the US, the long-established discourse in favor of maintaining a relatively permissive, product-based regulation without labeling has retained its dominance and is not seriously questioned by the wider public.

In the European Union, in contrast, actors backing GM foods and a permissive GM food policy are fewer than in the US, and not all are as convinced as their US counterparts. An important element is that the food chain is divided: while biotechnology companies and large food processors and producers are supportive of GM foods, farmers take an almost neutral approach ${ }^{166}$, while retailers have turned against GM foods. Moreover, supportive actors have a weak degree of cohesion in terms of positions, goals and activities, and their story-lines are divided between consumer orientation (food processors and producers) and biotechnology enthusiasm (biotechnology industry). They are relatively weak advocacy coalitions and discourse coalitions. Support from the European Commission, meanwhile, has been constant but cautious in terms of the language used. Few Member States are consistently supportive of GM foods, with positions fluctuating, for example with changes of government. Finally, the many shock events that took place throughout Europe during the late 1990s, although mostly unrelated to GM foods, have been devastating to the cause of GM food supporters, leading to intensive public criticism and distrust.

${ }^{166}$ It might be suggested that actors that are neither whole-heartedly supportive nor completely critical of GM foods and crops form a third "neutral" and relatively passive coalition within the European debate. Two actors would fit into this category: farmers and the European Commission. I choose to classify these actors as relatively reticent supporters. This choice emphasizes the role that this type of reticent supporter can play in weakening a supportive coalition. 
Turning to actors and coalitions opposing GM foods, in the US, actors critical GM foods have been only moderately successful at forming a successful advocacy coalition and a strong discourse coalition. This is one of the reasons why they have not succeeded in obtaining a more restrictive GM food and crop policy. In the EU, on the other hand, actors opposing GM food form both a successful advocacy coalition and a strong discourse coalition, which have successfully pushed for restrictive regulation of GM foods and crops and achieved discourse institutionalization.

US actors and actor coalitions opposing GM foods are relatively weak for three main reasons. First, GM food critics are fewer than in the EU, consisting of small farmers, consumers, and environmentalists. The US Congress and certain US states have contributed to the debate, but cannot be counted as actors in a coalition dependably supporting restrictive GM food policy. Food processors, producers and retailers remain supporters of agricultural biotechnology even if they have backed away from showing too much enthusiasm. They are not willing to be part of a coalition against GM foods. The second reason is those actors who do take a clear stand against GM foods make up weak advocacy coalitions and weak discourse coalitions, although they do display elements of both. Even though these actors do have some common positions, their interests are sufficiently different to make coordinated activity a second choice over independent action. Moreover, although story-lines have common elements, they are not a forceful and united narrative, thus making it difficult to qualify US actors against GM food as a discourse coalition. Third, the lack of comparable shock events occurring in the United States and a consequent lack of public interest or criticism have meant that US critics have been and remain unable to achieve high levels of credibility, acceptability and trust.

In contrast, EU actors and the actor coalition critical of GM foods are numerous and strong, as compared to the situation in the US. They are strongly united in their common goal of rendering policy more restrictive, and share important story-line elements. What is remarkable in the EU case is how the story-lines told by actors opposing GM foods have merged and have become mainstream. As in the case of GM food supporters, empirical study adds several useful considerations. Here again, the number and types of actors are crucial, in particular the presence of strongly opposed governmental actors (Member States) 
in the EU. What is more, shock events, as well as public opinion and distrust of regulators are crucial in explaining EU actors' success in achieving restrictive policy. A great part of their success was being able to seize a particular public mood and capitalize on it.

Table 16: US and EU actors and actor coalitions

\begin{tabular}{|c|c|c|}
\hline & $\begin{array}{c}\text { Supportive } \\
\text { or not actively opposed to GM } \\
\text { foods and crops }\end{array}$ & $\begin{array}{c}\text { Critical } \\
\text { or not actively supportive of GM } \\
\text { foods and crops }\end{array}$ \\
\hline Actors & $\begin{array}{l}\text { US: industry, large and mainstream } \\
\text { farmers, food processors and } \\
\text { producers, retailers, consumers, } \\
\text { regulators } \\
\text { EU: industry, large and mainstream } \\
\text { farmers, food processors and } \\
\text { producers, governmental actors } \\
\text { (European Commission) }\end{array}$ & $\begin{array}{l}\text { US: small and organic farmers, } \\
\text { environmentalists and NGOs } \\
\text { EU: small and organic farmers, } \\
\text { retailers, consumers, } \\
\text { environmentalists, governmental } \\
\text { actors (EU Member States) }\end{array}$ \\
\hline Main arguments & $\begin{array}{l}\text { - genetic engineering as an extension } \\
\text { of traditional breeding } \\
\text { - environmental benefits } \\
\text { - no proven health hazard } \\
\text { - alleviating world hunger }\end{array}$ & $\begin{array}{l}\text { - genetic engineering as something } \\
\text { fundamentally new } \\
\text { - unknown effects on health and the } \\
\text { environment } \\
\text { - too much power for agbiotech } \\
\text { multinationals } \\
\text { - ethically wrong ("patents on life") }\end{array}$ \\
\hline Impact on policy & $\begin{array}{l}\text { US: policy remains relatively } \\
\text { permissive } \\
\frac{\text { EU: policy remains relatively }}{\text { restrictive }}\end{array}$ & $\begin{array}{l}\underline{\mathrm{US}} \text { : policy remains relatively } \\
\text { permissive } \\
\underline{\text { EU: policy becomes increasingly }} \\
\text { restrictive }\end{array}$ \\
\hline
\end{tabular}




\section{CONCLUSION}

Summary This dissertation explains how and why GM food policies are different in the United States and the European Union. In order to create a comprehensive framework explaining GM food policy differences, I use three theoretical approaches - policy process theory, comparative historical analysis, and science and technology studies. This is a fitting choice for a broad, macrosocial topic like the transatlantic rift in GM food policy. It enables me to take several different explanatory angles into account that together can give a broad answer to the research question.

In accordance with the "why-question" I pose, my work is fundamentally defined by a search for causalities, and therefore by policy process theory and comparative historical analysis. At the same time, this study is very attentive to constructivist elements. For this reason, the use of science and technology studies proves to be enriching. This use of multiple theories brings with it the problem of epistemological pluralism, in my case, the inherent and practically insuperable contradiction between positivist and constructivist theories. I therefore establish that this study is written within a positivist tradition, but that constructivist elements are used to deepen the analysis. Moreover, the methodological strategy of developing a medium-range framework and of conducting a focused and systematic comparison of GM food policy in the EU and the US allows me to do the macro-social nature of my research question justice.

GM food policy, the dependent variable of this dissertation, is analyzed through a detailed study of regulatory policies in the US and the EU. A systematic comparison of GM food and crop policies in the areas of field testing and commercialization establishes that GM food policy in the US is relatively permissive, whereas GM food policy in the EU is relatively restrictive, both in terms of the number and complexity of rules and with respect to empirical data on the numbers and speed of authorizations.

Why have US and EU regulators developed such different policies on the same GM products? A first explanation of why GM food policies are different 
can be found by a comparison of "preceding policies" or, in the case of GM food, rDNA policies in the US and the EU in the 1970s and early 1980s, as well as the processes leading to the beginnings of GM food policy. My research shows that a policy reversal has taken place in both the EU and the US. In the US, extensive experience with and debate on the regulation of rDNA research in the 1970s facilitated a less heated debate and therefore acceptance of a relatively permissive regulation of rDNA technology's applications in the early 1980s. In contrast, the relative lack of regulatory experience and debate on rDNA research at the European Community level in the late 1970s and early 1980s was one of the elements leading to a controversial debate in the late 1980s, and to relatively restrictive EU GM food policy. Factors of great importance in bringing about this policy switch were public attitudes with respect to science and the environment in the 1970s and 1980s, as well as the fact that rDNA technology was developed in the US and not in Europe.

The second explanatory element presented consists of "paradigms", i.e. underlying beliefs regarding agricultural biotechnology. Empirical evidence reveals that GM food policies in the US and the EU are each based on two main paradigms. US policy primarily follows the economic competitiveness and the sound science paradigms, which are connected to an agribusiness model and a narrow definition of risk focusing on short-term health and the environmental safety. These paradigms are compatible with a relatively permissive GM food policy. The EU, on the other hand, is first and foremost guided by an environmental and health protection paradigm and by a precautionary principle paradigm, which find expression in a recent emphasis on sustainable agriculture, as well as broad definition of risks including long-term health and environmental aspects and ethical and socioeconomic concerns. These paradigms are coherent with a relatively restrictive GM food policy. An important finding is that, despite the predominant paradigms in each individual case, US and EU policies on GM foods both incorporate elements of each of the paradigms discussed, and that they find themselves in a constant struggle to strike a balance between economic progress and health and environmental protection.

The third explanatory element presented in this dissertation consists of the levels of success achieved by actors and actor coalitions in the GM food debate. In summary, GM food proponents in the United States have been more successful 
than their EU counterparts since they have been able to maintain relatively permissive regulations. In the EU, actors critical of GM foods have done better than their US counterparts since they have achieved increasingly restrictive regulation over the years. US actors in favor of GM foods and EU actors against GM foods are strong coalitions, both in terms of their common positions and actions, and of the discourses that connect them. In contrast, US actors against GM foods and EU proponents have not been able to form such strong and successful coalitions.

The empirical study of "preceding policies", "paradigms", and "actors and actor coalitions" further points towards the finding that certain contextual factors such the political system, as well as shock events in combination with public opinion, can be very important in determining policy outcomes.

Importance of individual explanatory elements This dissertation draws on policy process theory, comparative historical analysis, and science and technology studies to craft an explanatory framework suitable for shedding light on GM food policy differences in a comprehensive manner. These explanatory elements are discussed and analyzed separately in the chapters of this study. Empirical study suggests that each explanatory variable, taken alone, offers at least a partial explanation of GM food policy differences.

For the "preceding policies" variable, this means that, in the case of US and EU GM food policy, a relatively permissive preceding policy explains a relatively restrictive future GM food policy, while a relatively restrictive policy leads to a relatively permissive future GM food policy. For the "paradigms" variable, this study concludes that competitiveness and sound science paradigms favor relatively permissive policies, whereas protection and precautionary principle paradigms lead to relatively restrictive policies. Finally, empirical study of "actors and actor coalitions" suggests that a strong pro-GM food coalition, bound together by common actions and a strong story-line, can explain a relatively permissive GM food policy, while a similarly strong anti-GM food coalition results in relatively restrictive GM food policy.

Linking the explanatory elements Each variable presented in this study has its own weight and offers an analytical point of entry to the transatlantic rift in GM food policy. At the same time, it has become clear in frequent cross- 
references throughout this dissertation that these explanatory elements are interlinked.

For example, the impact of preceding policies on paradigms and actors and actor coalitions is apparent in the fact that current US and EU paradigms on GM foods developed as they did on the basis of previous regulatory experiences. Moreover, some current actors in the GM food debate were already active during the rDNA research debate, conditioning their later views on GM food and crops. Paradigms and actors are also interdependent, since actors and actor coalitions' positions and actions are strongly motivated by the paradigms expressed in storylines. At the same time, actors - often unconsciously - shape paradigms, either keeping them stable or changing them.

The context elements considered (political system, shock events and public opinion) can influence each of the three independent variables (preceding policies, paradigms, actors and actor coalitions) separately and thereby the GM food policy subsystem as a whole. For example, the explosiveness of the BSE crisis in the mid-1990s had an important impact on actors and paradigms, opening the way for a shift towards a more restrictive GM food policy. Public opinion, as measured and reported by institutions and the media, had a significant effect, especially during the development of policies on rDNA research in the US, and of GM food policies in the EU. Political system features and events, such as different electoral or judicial systems, or the election of US President Ronald Reagan in 1980, which in turn meant the beginning of the era of US supply-side economics and small government, have influenced individual explanatory elements, as well as the policy subsystem as a whole.

In summary, it is possible to suggest that taken together, the variables investigated offer a strong and comprehensive explanation of GM food policy outcomes. Relatively restrictive preceding rDNA research policy, together with the economic competitiveness and sound science paradigms, as well as a strong pro-GM food actor coalition have led to relatively permissive GM food policy in the US. Relatively permissive preceding rDNA research policy, combined with the protection and precautionary paradigms, as well as a strong anti-GM food actor coalition, led to relatively restrictive GM food policy in the EU. 
Figure 14 below shows the explanatory framework presented in Chapter 4 (Figure 13), with the addition of a series of arrows which represent the interdependences between explanatory variables. Arrows point from preceding policies to paradigms and actors and actor coalitions, and paradigms and actors/actor coalitions are linked by two arrows running both ways, one pointing towards paradigms and the other towards actors and actor coalitions. Context factors' impact is represented by arrows pointing toward the policy subsystem as a whole.

Figure 14: Analytical framework including variable interdependence

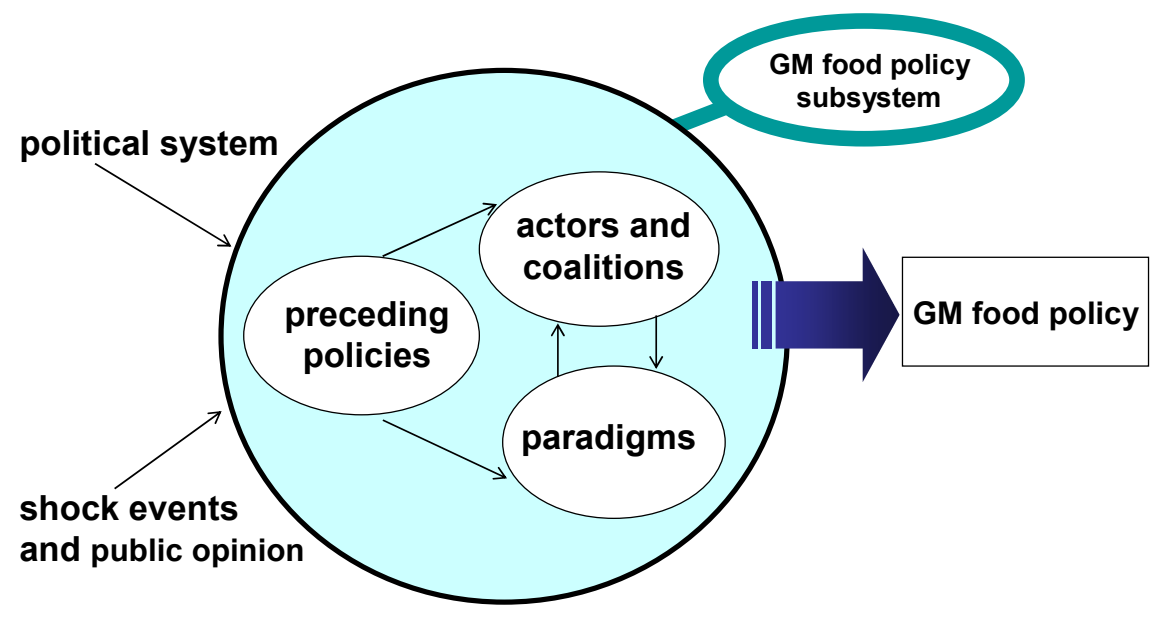

While all explanatory elements play an important role in accounting for GM food policies in the US and the EU, some elements carry more weight than others for the cases of the US and the EU respectively.

In the case of the United States, illustrated in Figure 15, the strongest explanatory elements are "preceding policies" and "actors and coalitions", which both have a strong impact on "paradigms" while context factors have a lesser impact. The US's previous experience with formulating guidelines for research with rDNA had a powerful influence on the paradigms that govern US GM food policy today. The fact that rDNA research guidelines were restrictive and based on conjectural risks furnished a strong basis for the sound science paradigm to develop with respect to agricultural biotechnology. As for the economic competitiveness paradigm, it was and remains mainly the result of individual actors' and actor coalitions' deeply held beliefs and preferences. US actors and 
actor coalitions are strongly influenced by the paradigms put in place in the early 1980 s, but there has been relatively little interaction of the two elements leading to changes in paradigms and/or actor positions over time, as has been the case in the EU. This lack of interaction over time is the reason why the arrow pointing from paradigms to actors/actor coalitions is not bold.

Context factors are less important in the US than in the EU in explaining GM food policy. As discussed in this dissertation, the relative lack of major shock events and resulting negative public opinion reinforced the positions and paradigms of actors and actor coalitions supporting relatively permissive GM food policy. Figure 15 below summarizes the interdependences between explanatory elements for the case of the United States, and shows the relative weight of "preceding policies" and "actors and actor coalitions". The US case shows a relatively linear policy development, which takes into account previous policy experience, and is strongly based on paradigms put in place by actors and actor coalitions when GM food policy was first developed, and that have not changed significantly over time.

\section{Figure 15: Analytical framework applied to the US}

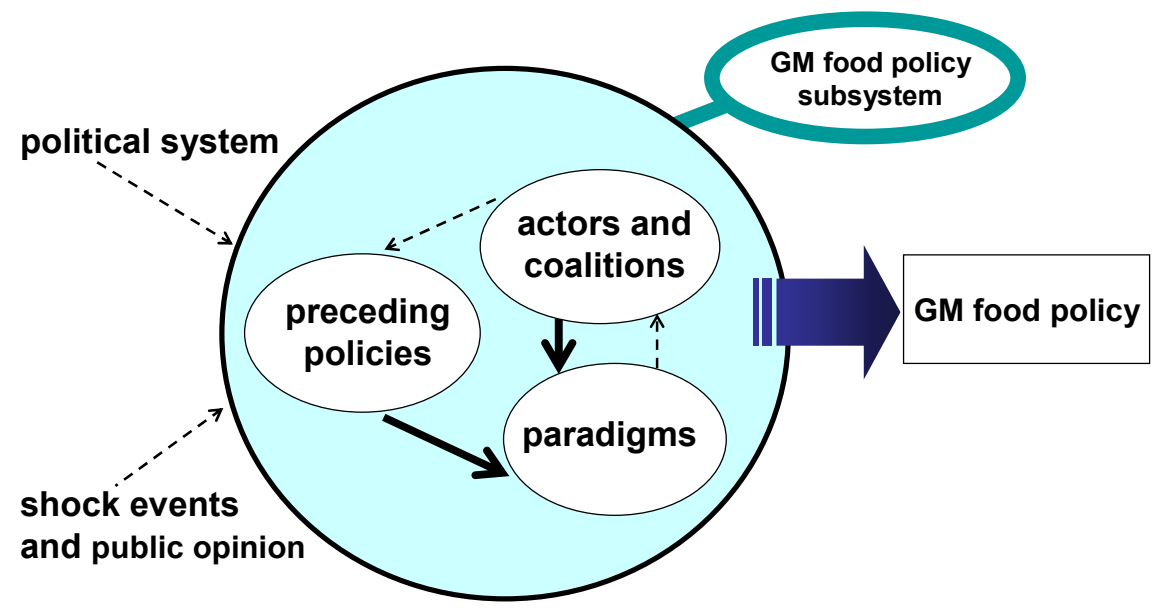

Turning to the European Union's GM food policy (see Figure 16), the most important explanatory elements are actors and actor coalitions, paradigms, and context factors. The EU's GM food policy represents a break with preceding policies, which had relatively little impact both on actors and actor coalitions, as 
well as on paradigms. Preceding policies might have played a more important role if it had not been for the impact of context factors. The increasingly environmentally aware political climate of the late 1980s, including the rise of green parties just when EU policy on GMOs was first being developed, and of course shock events such as the 1990s food and health scares, were particularly important. These events were exploited by actors and actor coalitions, who were able to influence paradigms considerably, causing them to undergo changes over time. These changing paradigms also had a significant impact on actors in the sense that actors adapted or modified their positions, thus making it possible for increasingly restrictive GM food policy to take shape. This interaction is represented by two bold arrows going from paradigms to actors/actor coalitions and vice versa. In summary, EU policy on GM food has developed as a result of context factors, as well as through interaction and mutual influence over time of paradigms and actors/actor coalitions. These dynamics are summarized in Figure 16.

Figure 16: Analytical framework applied to the EU

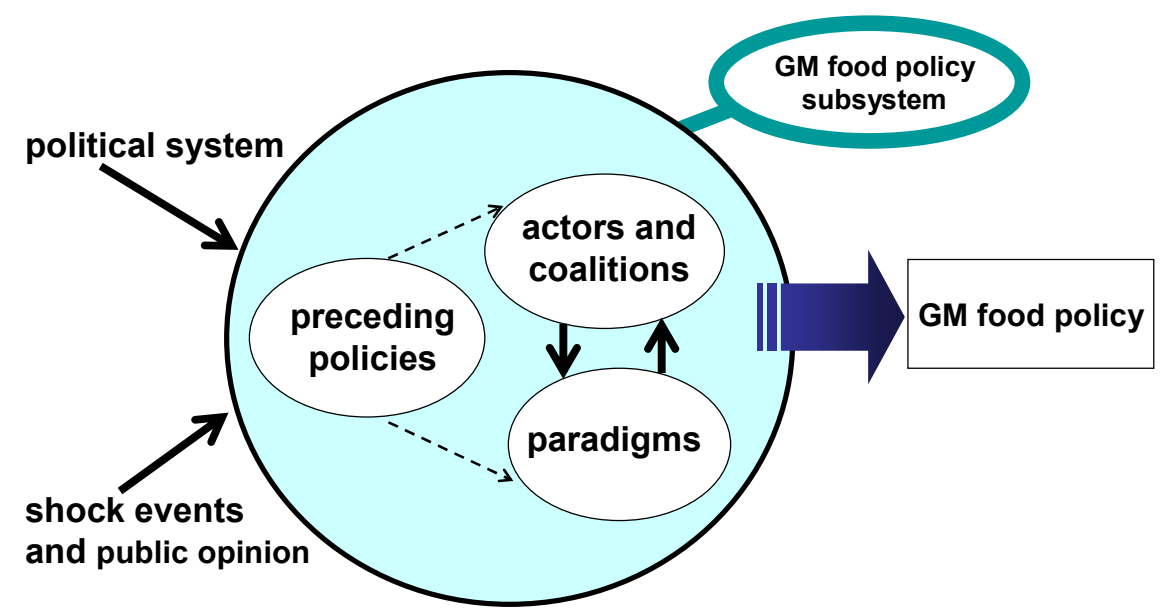

Reflections on the ongoing GM food policy debate At the time of writing, the debate surrounding GM food policy has been raging for about a decade and shows no sign of abating. The EU's de facto ban on GM foods and crops from 1999 to 2004 may have ended and GM product approvals restarted, but every single vote within the Council of the EU so far has shown that the issue is by no means politically resolved. The WTO ruling on the transatlantic trade dispute on 
GM food is expected for early 2006, after having been delayed several times. Even if a decision is taken, it is unlikely that the deep differences in this area will be set to rest.

Moreover, the story does not stop with GM crops and foods. New products involving genetic engineering that are gaining importance are plantmade pharmaceuticals (PMPs) and GM animals raised for food. Finally, the question of the transfer of genetic engineering technologies to the developing world will continue to inspire GM food proponents and incite its critics. The explanatory framework developed in this dissertation offers a useful tool to understand and explain these and other future conflicts.

This dissertation shows that regulatory differences in the field of GM food are not merely a reflection of trade policies and interests. The US's relatively permissive policy is not exclusively a function of its liberal trade policies, and the EU's relatively restrictive policy is not predominantly a protectionist strategy. Policy differences are much deeper-rooted than is often believed. The EU and the US have developed policies that can be explained through their different historical experiences, the paradigms underlying their policies, the different levels of success achieved by actors supportive and critical of GM foods, and the impact of context factors.

Attempting to determine who is right and who is wrong in the transatlantic debate on GM food policy, according to international trade rules, as is being attempted with the WTO case, may yield a short-term policy resolution, but cannot resolve the deeper underlying differences between the US and the EU. A lasting solution to these differences must be based on a long-term and reflective series of transatlantic discussions leading to a deeper understanding of all the elements explaining policy differences. 


\section{SOURCES}

\subsection{Interviewees}

(Affiliations, positions and titles reflect status at time of interview)

Bail, Christoph, European Commission, Environment Directorate-General, International Affairs, International Affairs Directorate (interviewed on 8 September 2004, Brussels).

Barach, Jeffrey, National Food Processors Association (NFPA, now Food Products Association, FPA), Regulatory Affairs, Vice President of Special Projects (interviewed on 15 June 2004, Washington, DC).

Barber, Simon, EuropaBio, Director of the Plant Biotechnology Unit (interviewed on 16 September 2004, Brussels).

Barnard, Andrew, European Commission, Enterprise Directorate-General, Consumer Goods Directorate, Policy Office (interviewed on 8 September 2004, Brussels).

Cantley, Mark, European Commission, Research Directorate-General, Biotechnology, Agriculture and Food Directorate, Adviser (interviewed on 7 September 2004, Brussels).

Caplan, Richard, US Public Interest Research Groups (US PIRG), Clean Water and Food Safety Advocate (interviewed on 10 June 2004, Washington, DC).

Clemence, Alistair, Monsanto, Head of Biotechnology Regulatory Affairs in Europe (interviewed on 15 September 2004, Brussels).

Fecitt, Rebecca, United States Department of Agriculture, Foreign Agricultural Service (APHIS-FAS), Member of Foreign Agricultural Service Biotech Group, Europe, Africa, Middle East (interviewed on 17 June 2004, Washington, DC).

Feller, Roxane, Committee of Professional Agricultural Organisations in the European Union and General Confederation of Agricultural Co-operatives in the European Union (COPA-COGECA), Legal Affairs, Food and Feed, Head of Unit (interviewed on 14 September 2004, Brussels).

Fernandez, Michael, Pew Initiative on Food and Biotechnology, Director of Science (interviewed on 11 June 2004, Washington, DC, co-interviewee: Keith Pitts).

Gall, Éric, Greenpeace, European Unit, GMO policy advisor (interviewed on 13 September 2004, Brussels).

Garcia, Edmundo Jr., Food and Drug Administration (FDA), Center for Food Safety and Applied Nutrition (CFSAN), Office of Food Additive Safety, Division of Biotechnology and GRAS Notice Review, Consumer Safety Officer (interviewed on 10 June 2004, Washington, DC, co-interviewee: Karin Ricker) 
Gaskill, Ron, American Farm Bureau Federation (AFBF), Director of Regulatory Relations (interviewed on 9 June 2004, Washington, DC).

Graciet, Bernard, Syngenta, Head of Brussels Office (15 September 2004, Brussels).

Hubbard, Kiki, The Center for Food Safety, Research Associate/Outreach Director (interviewed on 14 June 2004, Washington, DC).

Juma, Calestous, Harvard University, John F. Kennedy School of Government, Belfer Center for Science and International Affairs, Professor of the Practice of International Development, Director of Science Technology and Innovation (interviewed on 25 June 2004, Cambridge, MA).

Kayaert, Guido, Nestlé, Vice President of Relations with European Institutions (interviewed on 6 September 2004, Brussels).

Kettlitz, Beate, European Consumers' Organisation (BEUC), Food Department, Food Officer (interviewed on 14 September 2004, Brussels, co-interviewee: Patrick Sutton).

Kochenderfer, Karil, Grocery Manufacturers of America, Inc. (GMA), Director of Environmental Affairs and New Technologies (interviewed on 17 June 2004, Washington, DC).

Krimsky, Sheldon, Tufts University, Department of Urban and Environmental Policy \& Planning, Professor of Urban \& Environmental Policy \& Planning (interviewed on 25 June 2004, Medford, MA).

Mellon, Margaret, Union of Concerned Scientists (UCS), Food and Environment Program Director (interviewed on 9 June 2004, Washington, DC).

Meuffels, Oscar, Permanent Representation of the Kingdom of the Netherlands to the European Union, Agriculture, Nature and Food Quality Section, Representative on GMOs (interviewed on 17 September 2004, Brussels).

Milberg, Hayden, National Corn Growers Association (NCGA), Director of Public Policy (interviewed on 9 June 2004, Washington, DC).

Moore, Julia, National Science Foundation (NSF), Office of International Science and Engineering, Senior Advisor (interviewed on 8 June 2004, Arlington, VA).

Mousnier, Julien, European Commission, Environment Directorate-General, Protecting the Natural Environment Directorate, Policy Officer (interviewed on 6 September 2004, Brussels).

Olmedo, Carmen, Friends of the Earth Europe (FoEE), FoEE Biotechnology Programme and European GMO Campaign, European GMO Campaign Coordinator (interviewed on 3 September 2004, Brussels, co-interviewee: Geert Ritsema).

Ozer, Katherine, National Family Farm Coalition (NFFC), Executive Director (interviewed on 7 June 2004, Washington, DC).

Penning, Willem, European Commission, Health and Consumer Protection Directorate-General, Food Safety; Production and Distribution Chain Directorate, Head of Unit (interviewed on 3 September 2004, Brussels). 
Pitts, Keith, Pew Initiative on Food and Biotechnology, Director of Public Policy (interviewed on 11 June 2004, Washington, DC, co-interviewee: Michael Fernandez).

Ricker, Karin, Food and Drug Administration (FDA), Center for Food Safety and Applied Nutrition (CFSAN), Office of Food Additive Safety, Division of Biotechnology and GRAS Notice Review, Consumer Safety Officer (interviewed on 10 June 2004, Washington, DC, co-interviewee: Edmundo Garcia, Jr.).

Ritsema, Geert, Friends of the Earth Europe (FoEE), FoEE Biotechnology Programme and European GMO Campaign, European GMO Campaign Coordinator (interviewed on 3 September 2004, Brussels, co-interviewee: Carmen Olmedo).

Scheele, Karin, Member of the European Parliament (Austria, Member of the Group of the Party of European Socialists, Member of the Committee on the Environment, Public Health and Food Safety), Rapporteur of regulation on GM food and feed (interviewed on 7 September 2004, Brussels, co-interviewee: Sigrid Semlitsch).

Semlitsch, Sigrid, Assistant to Member of the European Parliament Karin Scheele (interviewed on 7 September 2004, Brussels, co-interviewee: Karin Scheele).

Strachan, Linda, Monsanto, Director of Governmental Affairs (interviewed on 8 June 2004, Washington, DC).

Sutton, Patrick, European Consumers' Organisation (BEUC), Food Department, Assistant (interviewed on 14 September 2004, Brussels, co-interviewee: Beate Kettlitz).

Taeymans, Dominique, Confederation of the Food and Drink Industries of the EU (CIAA), Director of Scientific and Regulatory Affairs (interviewed on 7 September 2004, Brussels).

Trambajolo, Amedeo, Permanent Representation of Italy to the European Union, Counselor for Environmental issues (interviewed on 13 September 2004, Brussels).

von Schomberg, Rene, European Commission, Research Directorate-General, Social Sciences and Humanities Directorate, Scientific/Technical Project Officer (interviewed on 2 September 2004, Brussels). Note: this interviewee expressed his views as a scholar and observer of the GM food debate, and not as a European Commission official.

Vonthron, Noëlle, EuroCommerce, Food Policy and Consumer Adviser (interviewed on 17 September 2004, Brussels).

White, James, United States Department of Agriculture (APHIS), Animal and Plant Health inspection Service (APHIS), Biotechnology Regulatory Services, Senior Operations Officer (interviewed on 16 June 2004, Riverdale, MD). 


\subsection{Primary and secondary literature}

(Hyperlinks are provided for documents made available primarily through the World Wide Web. All hyperlinks were checked on 26 August 2005.)

Abels, Gabriele. 2002. "Experts, Citizens, and Eurocrats - Towards a Policy Shift in the Governance of Biopolitics in the EU" European Integration online Papers (EIoP) Vol. 6 No. 19.

American Farm Bureau Federation. 2005 (Jan.) Agricultural Biotechnology International Markets. www.fb.org/issues/backgrd/biotech-inter05.201.doc.

American Farm Bureau Federation. We Are Farm Bureau. www.fb.org/about/thisis/.

Anderson, William L. / Bryson, Nancy S. / Davis, Robert C. Junior / Katz, Philip / Mannix, Richard J., Quarles, Steven P., Schwartz, Richard E. 2001. Biotechnology Deskbook. Washington, DC: Environmental Law Institute.

Animal and Plant Health Inspection Service. 2003 (10 March). Proposed Rule: Field Testing of Plants Engineered To Produce Pharmaceutical and Industrial Compounds Federal Register Vol. 68 No. 46: 11337-11340.

Animal and Plant Health Inspection Service. Biotechnology Permits Database. www.aphis.usda.gov/brs/database.html.

Ansell, Chris / Maxwell, Rahsaan / Sicurelli, Daniela. 2003. "Protesting Food: NGOs and Political Mobilization in Europe". Paper presented at conference entitled European Food Safety Regulation: The Challenge of Multi-Level Governance, 6-8 Nov. 2003, Berkeley, CA.

Ashby Working Party Report. 1975 (Jan.). London: Her Majesty’s Stationery Office. Excerpt reprinted in Watson, James D. / Tooze, John. 1981. The DNA Story: A Documentary History of Gene Cloning. San Francisco: W.H. Freeman and Company: 22.

Ashford, Tony. 1996. "Regulating Agricultural Biotechnology: reflexive modernisation and the European Union" Policy and Politics Vol. 24 No. 1: 125-135.

Barboza, David. 2003 (21 Feb.). "Development of Biotech Crops is Booming in Asia" New York Times.

Bauer, Martin W. / Gaskell, George. 2002. Biotechnology. The Making of a Global Controversy. Cambridge, UK: Cambridge University Press.

Baumgartner, Frank R. / Jones, Bryan D. 1993. Agendas and Instability in American Politics. Chicago: University of Chicago Press.

Beck, Ulrich. 1986. Risikogesellschaft. Auf dem Weg in eine andere Moderne. Frankfurt a. M.: Suhrkamp.

Berg, Paul et al. 1974. "Potential Biohazards of recombinant DNA molecules" Science 185:303.

Bernauer, Thomas. 2003. Genes, Trade, and Regulation. The Seeds of Conflict in Food Biotechnology. Princeton: Princeton University Press. 
Bernauer, Thomas / Meins, Erika. 2003 (Aug.). "Technological revolution meets policy and the market: Explaining cross-national differences in agricultural biotechnological regulation" European Journal of Political Research. Vol. 42 No. 5: 643-683.

Berry, Frances Stokes / Berry, William D. 1999. "Innovation and Diffusion Models in Policy Research" in Sabatier, Paul A. (ed.). Theories of the Policy Process. Boulder: Westview Press: 169-200.

Biotechnology Industry Organization. About BIO: Partner to a Dynamic Industry Coming of Age. www.bio.org/aboutbio/history.asp.

Biotechnology Industry Organization (BIO). Frequently Asked Questions On Agricultural Biotechnology. www.bio.org/foodag/faq.asp.

Birkland, Thomas A. 1998. "Focusing Events, Mobilization, and Agenda Setting" Journal of Public Policy Vol. 18 No. 1: 53-74.

"Biss ins Ungewisse". 2000. Test Magazin (Stiftung Warentest). No.8.

Bomberg, Elizabeth. 1998. Green Parties and Politics in the European Union. London/New York: Routledge.

Braun, Dietmar / Gilardi, Fabrizio. 2005. “Taking 'Galton's Problem’ seriously. Towards a theory of policy diffusion" Paper for presentation at the $46^{\text {th }}$ Annual Convention of the International Studies Association, Hawaii, 1-5 March 2005. wwwpeople.unil.ch/fabrizio.gilardi/download/braun_gilardi_ISA2005.pdf.

Bruckmeier, Karl / Ehlert, Wiking (eds.). 2002. The Agri-Environmental Policy of the European Union. The Implementation of the Agri-Environmental Measures within the Common Agricultural Policy in France, Germany, and Portugal. Frankfurt/Main et al.: Peter Lang.

Callon, Michel. 1986. "Some elements of a sociology of translation: Domestication of the scallops and the fishermen of St Brieuc Bay" in Law, J. (ed.) Power, Action and Belief. A New Sociology of Knowledge? London: Routledge \& Kegan Paul: 196-233.

CambsQuality. 2004. Product Liability - the United Kingdom Perspective with Observations on the USA and European Union - an Introduction. www.cambsquality.com/sitebuildercontent/sitebuilderfiles/product liability su mmary.pdf.

Cantley, Mark. 1995. "The Regulation of Modern Biotechnology: A Historical and European Perspective" in Brauer, Dieter (ed.) Biotechnology: Legal, Economic and Ethical Dimensions Vol. 12 Weinheim: VCH Verlag.

Cantley, Mark / Hoban, Thomas / Sasson, Albert. 1999. "Regulations and consumer attitude towards biotechnology" Nature Biotechnology Vol. 17 Supplement: BV37-BV40.

Cardwell, Michael. 2004. The European Model of Agriculture. Oxford: Oxford University Press.

Carson, Rachel. 2002 [1962]. Silent Spring. Boston/New York: Houghton Mifflin.

Center for Disease Control and Prevention. 2001 (11 June). Investigation of Human Health Effects Associated with Potential Exposure to Genetically 
Modified Corn. A Report to the U.S. Food and Drug Administration from the Centers for Disease Control and Prevention.

Charles, Daniel. 2001. Lords of the Harvest. Biotech, Big Money, and the Future of Food. Cambridge, MA: Perseus Publishing.

Christoforou, Theofanis. 2004. "The regulation of genetically modified organisms in the European Union: The interplay of science, law and politics" Common Law Market Review Vol. 41: 637-709.

Cobb, Roger W. / Elder, Charles D. 1972. Participation in American Politics. The Dynamics of Agenda-Building. Baltimore: Johns Hopkins University Press.

Code of Federal Regulations. http://www.gpoaccess.gov/cfr/index.html.

Code of Federal Regulations, Title 40, Part 152

(Protection of the Environment -Pesticide Registration and Classification Procedures, 40 CFR 152).

Code of Federal Regulations, Title 40, Part 172 (Protection of the Environment Experimental Use Permits, 40 CFR 172).

Code of Federal Regulations, Title 40, Part 174

(Protection of the Environment - Procedures and Requirements for PlantIncorporated Protectants, 40 CFR 174).

Code of Federal Regulations, Title 7, Part 340

(Agriculture - Introduction Of Organisms And Products Altered Or Produced Through Genetic Engineering Which Are Plant Pests Or Which There Is Reason To Believe Are Plant Pests, 7 CFR 340).

Committee of Agricultural Organisations in the European Union / General Committee for Agricultural Cooperation in the European Union. 2000 (21 Jan.) Position of COPA and COGECA on the Use of Gene Technology in Agriculture. www.copa-cogeca.be/pdf/pr 00 06fle.pdf.

Constitution of the United States of America. To be found, for example, at http://www.law.cornell.edu/constitution/constitution.overview.html.

Consumers Union. 1998a. Genetic Engineering is not an Extension of Conventional Plant Breeding (author: Hansen, Michael) www.consumersunion.org/food/widecpi200.htm.

Consumers Union. 1998b. 1998 (April). Why We Need Labeling of Genetically Engineered Foods. (authors: Hansen, Michael and Halloran, Jean). www.consumersunion.org/food/whywenny 798.htm.

Cook, Guy. 2004. Genetically Modified Language: The discourse of arguments for GM crops and food. London/New York: Routledge.

Council for Responsible Genetics. 2000 (summer). Frequently Asked Questions About Genetically Engineered Food. www.gene-watch.org/programs/food/foodFAQ.html.

Council of the European Union. 1982 (30 June). Council Recommendation 82/472/EEC of 30 June 1982 concerning the registration of work involving recombinant deoxyribonucleic acid (DNA). Official Journal L 213. 21 July 1982: 15. 
Council of the European Union 1990a (23 April). Council Directive 90/219/EEC of 23 April 1990 on the contained use of genetically modified microorganisms. Official Journal L 117. 8 May 1990: 1-14.

Council of the European Union. 1990b (23 April). Council Directive 90/220/EEC of 23 April 1990 on the deliberate release into the environment of genetically modified organisms. Official Journal L 117. 8 May 1990: 15-27 (repealed).

Council of the European Union. 1991 (24 June). Council Regulation 2092/91 of 24 June 1991 on organic production of agricultural products and indications referring thereto on agricultural products and foodstuffs. Official Journal L 198. 22 July 1991: 1-15.

Council of the European Union. 1998 (26 May). Council Regulation (EC) No 1139/98 of 26 May 1998 concerning the compulsory indication of the labelling of certain foodstuffs produced from genetically modified organisms of particulars other than those provided for in Directive 79/112/EEC Official Journal L 159. 3 June 1998: 4-7 (repealed).

Council of the European Union. 1999a (28 June). 1999/468/EC: Council Decision of 28 June laying down the procedures for the exercise of implementing powers conferred on the Commission. Official Journal L 184. 17 July 1999: 23-26.

Council of the European Union. 1999b (26 Oct.). Draft Minutes of the $2194^{\text {th }}$ Council meeting (Environment) held in Luxembourg on 24 and 25 June 1999. 9433/1/99 REV 1.

Cummins, Ronnie / Lilliston, Ben. 2004. Genetically Engineered Food. A SelfDefense Guide for Consumers. New York: Marlowe \& Company.

Dalton, Russel J. 1994. The Green Rainbow: Environmental Groups in Western Europe. New Haven / London: Yale University Press.

Danish Ministry of the Environment. Environmental Protection Agency. 1986. Act No. 288 of June 4, 1986 on Environment and Genetic Engineering.

Dawkins, Kristin. 2003. Gene Wars: The Politics of Biotechnology. 2nd edition ( $\left.1^{\text {st }}: 1997\right)$. New York: Seven Stories Press.

de Sadeleer, Nicolas. 2001. "Le statut juridique du principe de précaution" in Ewald, François / Gollier, Christian / de Sadeleer, Nicolas. Le principe de précaution. Paris: Presses Universitaires de France : 75-103.

de Steiguer, J.E. 1997. The Age of Environmentalism. Boston et al.: WCB McGraw-Hill.

deLeon, Peter. 1999. "The Stages Approach to the Policy Process: What Has It Done? Where Is It Going?" in Sabatier, Paul A. (ed.). 1999. Theories of the Policy Process. Boulder: Westview Press: 19-32.

Denzin, Norman K. / Lincoln, Yvonna S. 2000. "The Discipline and Practice of Qualitative Research" in Denzin, Norman K. / Lincoln, Yvonna. 2000. Handbook of Qualitative Research. $2^{\text {nd }}$ edition. Thousand Oaks, CA: Sage: 128.

Devine. Fiona. 1995. "Qualitative Methods" in Marsh, David / Stoker, Gerry (eds). Theory and Methods in Political Science. London: Macmillan Press: 137153. 
Dratwa, Jim. 2002. "Taking Risks with the Precautionary Principle: Food (and the Environment) for Thought at the European Commission" Journal of Environmental Policy and Planning Vol. 4: 197-213.

Dunlap, Riley E. / Mertig, Angela G. 1992. American Environmentalism. The U.S. Environmental Movement, 1970-1990. New York: Taylor and Francis.

Durant, John / Bauer, Martin W. / Gaskell, George (eds.). 1998. Biotechnology in the Public Sphere. A European Sourcebook. London: Science Museum.

Dye, Thomas R. 1972. Understanding public policy. Englewood Cliffs, NJ: Prentice-Hall.

Dye, Thomas R. 1976. What Governments Do, Why they do it, What difference it Makes. Tuscaloosa: University of Alabama Press.

Easton, David. 1965. A Framework for Political Analysis. Englewood Cliffs, NJ: Prentice Hall.

Echols, Marsha. 1998 (summer). "Food Safety Regulation in the European Union and the United States: Different Cultures, Different Laws" Columbia Journal of European Law.

Enquete-Kommission. 1987. Bericht der Enquete-Kommission "Chancen und Risiken der Gentechnologie" des 10. Deutschen Bundestages.

Environmental Protection Agency. Introduction to Biotechnology Regulation for Pesticides.

www.epa.gov/pesticides/biopesticides/regtools/biotech-reg-prod.htm.

Environmental Protection Agency. Plant Incorporated Protectants. http:/www.epa.gov/pesticides/biopesticides/pips/index.htm.

Epp, Astrid. 2003. Law in Conflict. The Regulation of Genetically Modified Food in Germany and in the United States. Dissertation, Universität Bielefeld, Fakultät für Soziologie, Institut für Wissenschafts- und Technikforschung.

ETC Group (Action Group on Erosion, Technology and Concentration). 2005a (Sept./Oct.). Global Seed Industry Concentration - 2005. ETC Communiqué Issue 90. http://www.etcgroup.org/documents/Comm90GlobalSeed.pdf.

ETC Group (Action Group on Erosion, Technology and Concentration). 2005b (Nov./Dec.). Oligopoly, Inc. 2005: Concentration in Corporate Power. ETC Communiqué Issue 91. http://www.etcgroup.org/documents/Comm82OligopNovDec03.pdf.

"EU Declines US Call to Reassure Africa on GMO Food”. 2002 (22 Aug.). Reuters. http://www.gmfoodnews.com/re220802.txt.

“EU Ministers ‘ban’ GMOs, delay scrap car law”. 1999 (24 June). ENDS Environmental Daily.

EuropaBio. Green Biotech. www.europabio.org/green_biotech.htm\#what.

EuropaBio. Frequently Asked Questions about Plant Biotechnology. http://www.europabio.org/bi_faq plants.htm.

European Commission. 2000a (10 Jan.). Commission Regulation (EC) No 49/2000 of 10 January 2000 amending Council Regulation (EC) No 1139/98 concerning the compulsory indication on the labelling of certain foodstuffs produced from genetically modified organisms of particulars other than those 
provided for in Directive 79/112/EEC Official Journal L 006. 11 Jan. 2000: 1314 (repealed).

European Commission 2000b (10 Jan). Commission Regulation (EC) No 50/2000 of 10 January 2000 on the labelling of foodstuffs and food ingredients containing additives and flavourings that have been genetically modified or have been produced from genetically modified organisms. Official Journal L 006. 11 Jan. 2000: 15-17 (repealed).

European Commission. 2000c (12 Jan.). White Paper on Food Safety. $\operatorname{COM}(1999) 719$.

European Commission. 2000d (2 Feb). Communication from the Commission on the precautionary principle. $\mathrm{COM}(2000) 1$.

European Commission. 2001 (25 July). European Governance. A White Paper. $\operatorname{COM}(2001) 428$ final.

European Commission. 2002. Communication from the Commission to the Council, the European Parliament, the Economic and Social Committee and the Committee of the Regions. Life sciences and biotechnology - a Strategy for Europe. COM(2002)27 final. 23 Jan.

European Commission. 2003 (21 March). "Europeans and Biotechnology in 2002" Special Eurobarometer 58.0 No. 177 (2 ${ }^{\text {nd }}$ edition 21 March 2003).

European Commission. 2005a (20 May). Questions and Answers on the Regulation of GMOs in the European Union.

europa.eu.int/comm/food/food/biotechnology/gmfood/qanda_en.pdf.

European Commission. 2005b (June). "Social Values, Science \& Technology". Special Eurobarometer 63.1 No 225.

European Commission. 2005c (June). "Europeans, Science and Technology". Special Eurobarometer 63.1 No 224.

European Commission. Biotechnology. Environment Directorate-General. europa.eu.int/comm/environment/biotechnology/index en.htm.

European Commission. Deliberate releases and placing on the EU market of Genetically Modified Organisms (GMOs) Directorate General Joint Research Centre. gmoinfo.jrc.it/default.asp.

European Commission. Genetically Modified (GM) Foods authorised in the European Union under the Novel Food Regulation (EC) 258/97. Updated 26 July 2005. europa.eu.int/comm/food/food/biotechnology/authorisation/258-97ec authorised en.pdf.

European Commission. GM Food \& Feed-Authorisation. Directorate-General Health and Consumer Protection. europa.eu.int/comm/food/food/biotechnology/authorisation/index en.htm.

European Consumers' Organisation. 1996 (18 June). Novel Foods: Progress to date on the draft and expectations for the future - Consumer Perspective Perspective - Submission of Kees de Winter for the European Food Law Conference 25-26 June 1996, Sheraton Hotel, Brussels www.beuc.org/Content/Default.asp?PageID=105.

European Consumers' Organisation. 2002 (24 April). GM food - Now or Never? Press release. www.beuc.org/Content/Default.asp?PageID=105. 
European Council. 2000 (24 March). Presidency Conclusions: Lisbon European Council 23 and 24 March 2000.

European Food Safety Authority. Applications under Regulation (EC) 1829/2003 on Genetically Modified Food and Feed [GM Food Feed applications]. Updated 5 August 2005 www.efsa.eu.int/science/gmo/gm_ff_applications/catindex_en.html.

European Molecular Biology Organization. 1976 (14-15 Feb.). Report on the First Meeting of the EMBO Standing Advisory Committee on Recombinant $D N A$. Excerpt reprinted in Watson, James D. / Tooze, John. 1981. The DNA Story: A Documentary History of Gene Cloning. San Francisco: W.H. Freeman and Company: 213.

European Parliament. 1987 (16 Feb.). Resolution on Biotechnology in Europe and the Need for an Integrated Policy. Doc A2-134/86. Official Journal C076. 23 March 1987: 25.

European Parliament. 2003 (18 Dec.). European Parliament resolution on coexistence between genetically modified crops and conventional and organic crops. 2003/2098 (INI) Official Journal 091 E. 15 April 2004: 680-683.

European Parliament / Council of the European Union. 1997 (27 Jan.). Regulation (EC) No 258/97 of the European Parliament and of the Council of 27 January 1997 concerning novel foods and novel food ingredients. Official Journal L 043. 14 February 1997: 1-6.

European Parliament / Council of the European Union. 2001 (12 March). Directive 2001/18/EC of the European Parliament and of the Council of 12 March 2001 on the deliberate release into the environment of genetically modified organisms and repealing Council Directive 90/220/EEC. Official Journal L 106. 17 April 2001: 1-39.

European Parliament / Council of the European Union. 2003a (22 Sept.). Regulation (EC) No 1829/2003 of the European Parliament and of the Council of 22 September 2003 on genetically modified food and feed (Text with EEA relevance). Official Journal L 268. 18 Oct. 2003: 1-23.

European Parliament / Council of the European Union. 2003b (22 Sept.). Regulation (EC) No 1830/2003 of the European Parliament and of the Council of 22 September 2003 concerning the traceability and labelling of genetically modified organisms and the traceability of food and feed products produced from genetically modified organisms and amending Directive 2001/18/EC. Official Journal L 268. 18 Oct. 2003: 24-28.

European Union. Key players in EU legislation - EU lawdefinitions.europa.eu.int/eur-lex/en/about/pap/process and players2.html\#1.

"Europeans Divided on E. Coli Manipulation" 1974 (28 Aug.) Medical Tribune 15:3. Reprinted in Watson, James D. / Tooze, John. 1981. The DNA Story: A Documentary History of Gene Cloning. San Francisco: W.H. Freeman and Company: 21.

Falk, Michael C. / Chassy, Bruce M. / Harlander, Susan K. / Hoban, Thomas J., / McGloughlin / Martina N. / Akhlaghi, Armin R. 2002 "Food Biotechnology: Benefits and Concerns" American Society for Nutritional Sciences: 1384-1390. Journal of Nutrition Vol. 132 No. 6: 1384-1390. 
Falkow, Stanley. 1978 (19 April). Letter to Donald Fredrickson (Director of the National Institutes of Health). Published in Watson, James D. / Tooze, John. 1981. The DNA Story: A Documentary History of Gene Cloning. San Francisco: W.H. Freeman and Company: 344-345.

Federoff, Nina / Brown, Nancy Marie. 2004. Mendel in the Kitchen. A Scientist's View of Genetically Modified Foods. Washington, DC: Joseph Henry Press.

Feffer, John. 2004 (2 Dec.). "Asia Holds the Key to the Future of GM Food" YaleGlobal. http://yaleglobal.yale.edu/display.article?id=4956.

Fischer, Frank and Forrester, John (eds.). 1993. The Argumentative Turn in Policy Analysis and Planning. Durham and London: Duke University Press.

Fleck, Ludwik. 1979 [1935]. Genesis and Development of a Scientific Fact. Chicago: University of Chicago Press.

Flew, Antony. 1999. A Dictionary of Philosophy. Revised second edition. New York: Gramercy Books.

Flick, Uwe / von Kardorff, Ernst / Steinke, Ines. 2000. „Was ist qualitative Forschung? Einleitung und Überblick“" in Flick, Uwe / von Kardorff, Ernst / Steinke, Ines (eds.). Qualitative Forschung. Ein Handbuch. Reinbeck bei Hamburg: Rowohlt Taschenbuch Verlag: 13-29).

Food and Agriculture Organization / World Health Organization. 1996. Biotechnology and food safety. Report of a Joint FAO/WHO Consultation, Rome, Italy, 30 September - 4 October 1996. FAO Food and Nutrition Paper 61.

Food and Agriculture Organization. FAOSTAT database. faostat.fao.org.

Food and Drug Administration. 1992 (29 May). Statement of Policy: Foods Derived From New Plant Varieties Federal Register Vol. 57 No. 104: 2298423004.

Food and Drug Administration. 1997 (Oct.). "Guidance on Consultation Procedures: Foods Derived from New Plant Varieties". www.cfsan.fda.gov/ 1rd/consulpr.html.

Food and Drug Administration. 2001a (18 Jan.). Draft Guidance for Industry: Voluntary Labeling Indicating Whether Foods Have or Have Not Been Developed Using Bioengineering; Availability Federal Register Vol. 66 No. 12: 4839-4842.

Food and Drug Administration. 2001b (18 Jan.). Premarket Notice Concerning Bioengineered Foods Federal Register Vol. 66 No. 12: 4706-4738.

Food and Drug Administration. List of Completed Consultations on Bioengineered Foods http://www.cfsan.fda.gov/ 1rd/biocon.html.

Food Products Association. 2004 (16 April). EU Biotech Labeling and Traceability Requirements 'Will Be A Serious Barrier to International Trade' Says NFPA. Press Release www.fpa-food.org/content/newsroom/article.asp?id=25.

Food Products Association. What is Food Biotechnology? Consumer Fact Sheet. www.fpa-food.org/upload/pdfs/FoodBiotechnology.pdf. 
Ford, Glyn / Lake, Gordon. 1991. „Evolution of European science and technology policy" Science and Public Policy Vol. 18 No. 1 (February): 38-50.

Fredrickson, Donald S. 2001. The Recombinant DNA Controversy, A Memoir: Science, Politics and the Public Interest 1974-1981. Washington, DC: ASM Press.

Friends of the Earth USA. 2004. 2004 Annual Report. Washington, DC: Friends of the Earth.

Friends of the Earth Europe. About Us. www.foeeurope.org/about/english.htm.

Friends of the Earth USA. Organic, not genetically engineered. www.foe.org/camps/comm/safefood/gefood/index.html.

Gaskell, George. 2000. "Agricultural Biotechnology and Public Attitudes in the EU” AgBioForum Vol. 3 No. 2/3: 87-96.

Gaskell, George / Bauer, Martin W. / Durant, John / Allum, Nicholas. 1999. "Worlds Apart? The Reception of Genetically Modified Foods in Europe and the U.S.” Science Vol. 285, 16 July: 384-387.

Gaskell, George / Bauer, Martin W. 2001. Biotechnology 1996-2000: the years of controversy. London: Science Museum.

Gaskell, George / Bauer, Martin W. / Allum, Nick / Lindsay, Nicola / Durant, John / Lueginger, Julia. 2001a "United Kingdom: spilling the beans on genes" in Gaskell, George / Bauer, Martin W. Biotechnology 1996-2000: the years of controversy. London: Science Museum: 292-306.

Gaskell, George / Thompson, Paul / Allum, Nick. 2002. "Words Apart? Public opinion in Europe and the USA" in Bauer, Martin W. / Gaskell, George. Biotechnology. The Making of a Global Controversy. Cambridge, UK: Cambridge University Press: 351-375.

General Agreement on Tariffs and Trade (GATT). 1947.

General Agreement on Tariffs and Trade (GATT). 1994 (“GATT1994”).

Gerring, John. 2001. Social Science Methodology. A Critical Framework. Cambridge, UK: Cambridge University Press.

Giddens, Anthony. 1999. "Risk and Responsibility" Modern Law Review Vol. 62 No.1: 1-10.

Glowka, Lyle. 2003. Law and Biotechnology. Selected issues of relevance to food and agriculture. FAO Legislative Study 78. Rome: Food and Agriculture Organization of the United Nations.

Gottweis, Herbert. 1998. Governing Molecules: The Discursive Politics of Genetic Engineering in Europe and the United States. Cambridge, MA and London: the MIT Press.

Greenberg, David / Graham, Mary. 2000. "Improving Communication About New Food Technologies" in Teich, Albert H / Nelson, Stephen D / McEnaney, Celia / Lita, Stephen J. (eds.) American Association for the Advancement of Science: Science and Technology Policy Yearbook 2001. Washington, DC: American Association for the Advancement of Science (AAAS).

Greenpeace International. Say no to genetic engineering. www.greenpeace.org/international/campaigns/genetic-engineering. 
Greenpeace International. Trolley Watch. GE Food in Europe weblog.greenpeace.org/ge/map.html.

Greenpeace International / GeneWatch UK. GM Contamination Register www.gmcontaminationregister.org/.

Grocery Manufacturers of America. Biotechnology - Alliance for Better Foods. www.gmabrands.com/publicpolicy/docs/whitepaper.cfm?DocID=309\&.

Groß, Detlef. 2001. Die Produktzulassung von Novel Food. Berlin: Duncker \& Humblot.

Gutteling, Jan / Midden, Cees / Smink, Carla / Meijnders, Anneloes. 2001. "The Netherlands: controversy or consensus?" in Gaskell, George / Bauer, Martin W. Biotechnology 1996-2000: the years of controversy. London: Science Museum: 229-236.

Hajer, Maarten. 1995. The Politics of Environmental Discourse. Oxford: Oxford University Press.

Hall, Peter A. 1986. Governing the Economy. The Politics of State Intervention in Britain and France. Oxford: Polity Press.

Hall, Peter A. 1993. "Policy Paradigms, Social Learning, and the State: The Case of Economic Policymaking in Britain" Comparative Politics Vol. 25 No. 3 (April), 275-296.

Hall, Peter A. / Taylor, Rosemary C.R. 1996. "Political Science and the Three New Institutionalisms” Political Studies XLIV: 936-957.

Hall, Peter A. 2003. "Aligning Ontology and Methodology in Comparative Research" in Mahoney, James / Rueschemeyer, Dietrich (eds). Comparative Historical Analysis in the Social Sciences. Cambridge, UK: Cambridge University Press: 373-404.

Hague, Rod / Harrop, Martin / Breslin, Shaun. 1998. Comparative government and politics: an introduction. London: Macmillan Press.

Haniotis, Tassos. 2000. "Regulating Agri-food Production in the US and the EU" AgBioForum Vol. 3 Nos. 2-3: 84-86.

Haniotis, Tassos. 2001. "The Economics of Agricultural Biotechnology:

Differences and Similarities in the US and EU" in Nelson, Gerald C. (ed.) Genetically Modified Organisms in Agriculture: Economics and Politics. San Diego et al.: Academic Press.

Harris, Gardiner. 2005 (6 Aug.). "F.D.A. Responds to Criticism with New Caution" New York Times.

Hart, Kathleen. 2002. Eating in the Dark: America's Experiment with Genetically Engineered Food. New York: Pantheon books.

Heller, Chaia. 2002. "From Scientific Risk to Paysan Savoir-Faire: Peasant Expertise in the French and Global Debate over GM crops" Science as Culture Vol. 11 No. 1: 5-37.

Hennis, Marjoleine. 2002. "New Transatlantic Conflicts: American and European Food Policies Compared" EUI Working Paper RSC 2002/1. San Domenico di Fiesole. 
Héritier, Adrienne (ed.). 1993. "Policy-Analyse: Kritik und Neuorientierung" Politische Vierteljahresschrift Sonderheft 24.

Herwig, Alexia. 2004. A Postmodern Critique of the Regulation of the Trade, Safety and Consumer Choice Issues concerning GM-Foods through WTO Law. Ph.D. dissertation. New York University.

Hoban, Thomas J. 1997. "Consumer acceptance of biotechnology: An international perspective" Nature Biotechnology Vol. 15 (March): 232-234.

Hofferbert, Richard. 1974. The Study of Public Policy. Indianapolis: BobbsMerrill.

House, Peter W./Shull, Roger D. 1991. The Practice of Policy Analysis. Washington, DC: Compass.

Howlett, Michael / Ramesch, M. 1995. Studying Public Policy: Policy Cycles and Policy Subsystems. Toronto: Oxford University Press.

Ingersent, Ken A. / Rayner, A.J. 1999. Agricultural Policy in Western Europe and the United States. Cheltenham, UK / Northampton, MA: Edward Elgar.

Immergut, Ellen M. 1992. "The rules of the game: The logic of health policymaking in France, Switzerland, and Sweden" in Steinmo, Sven / Thelen, Kathleen / Longstreth, Frank (eds.). 1992. Structuring politics. Historical institutionalism in comparative analysis. Cambridge, UK: Cambridge University Press: 57-89.

Immergut, Ellen M. 1998. "The Theoretical Core of the New Institutionalism" Politics and Society 26(1): 5-31.

International Food Biotechnology Council. 1990 (Dec.). "Biotechnologies and Food: Assuring the Safety of Foods Produced by Genetic Modification" Regulatory Toxicology and Pharmacology Vol. 12 No. 3 Part 2.

Isaac, Grant E. 2002. Agricultural Biotechnology and Transatlantic Trade Regulatory Barriers to GM Crops Oxon / New York: CABI Publishing.

James, Clive. 1997. "Global Status and Distribution of Commercial Transgenic Crops in 1997” Biotechnology and Development Monitor Brief No. 35: 9-12.

James, Clive. 2004. Global Status of Commercialized Biotech/GM Crops: 2004 (Preview). International Service for the Acquisition of Agri-Biotech Applications (ISAAA) Brief No. 32.

Jamison, Andrew. 1987. "National Styles of Science and Technology: A Comparative Model" Sociological Inquiry 2: 144-158.

Jamison, Andrew. 1991. National Styles in Technology Policy, in: Hilpert, U. (ed.): State Policies and Techno-Industrial Innovation. London/New York: Routledge.

Jamison, Andrew / Baark, Erik. 1990. "Modes of Biotechnology Assessment in the USA, Japan and Denmark" Technology Analysis \& Strategic Management Vol. 2 No. 2: 111-127.

Jasanoff, Sheila. 1991. "American Exceptionalism and the Political Acknowledgment of Risk" Daedalus Vol. 119. No. 4: 61-81.

Jasanoff, Sheila. 1995. "Product, process, or programme: three cultures and the regulation of biotechnology" in Bauer, Martin. 1995. Resistance to New 
Technology: Nuclear Power, InformationTtechnology, and Biotechnology. Cambridge, UK: Cambridge University Press.

Jasanoff, Sheila. 2000. "Technological Risk and Cultures of Rationality" in National Research Council, Incorporating Science, Economics, and Sociology in Developing Sanitary and Phytosanitary Standards in International Trade, Proceedings of a Conference. Washington, DC: National Academy Press: 6584.

Jasanoff, Sheila. 2004. States of Knowledge: The Co-production of Science and Social Order. London/New York: Routledge.

Jasanoff, Sheila. 2005. Designs on Nature: Science and Democracy in Europe and the United States. Princeton, NJ: Princeton University Press.

Jasanoff, Sheila / Markle, Gerald E. / Petersen, James C. / Pinch, Trevor (eds.). 1995. Handbook of Science and Technology Studies. London: Sage.

Jobert, Bruno / Muller, Pierre. 1987. L'État en action. Politiques publiques et corporatismes. Paris: Presses universitaires de France.

Joly, Pierre Benoît / Marris, Claire. 2001. "Agenda-Setting and Controversies: A Comparative Approach to the Case of GMOs in France and the United States" Paper presented at a Workshop organized by INSEAD and Berkeley University of California, INSEAD, Fontainebleau, June 8-9, 2001.

Jones, Charles O. 1970. An Introduction to the Study of Public Policy. Wadsworth: Belmont, CA.

Jones, Mary Ellen. 1999. Politically Corrected Science: The Early Negotiation of U.S. Agricultural Biotechnology. Ph.D. dissertation. Virginia Polytechnic Institute and State University.

Kaufman, Marc. 2001 (14 June). "Genetically Engineered Corn Cleared in 17 Food Reactions" Washington Post.

Kempf, Hervé. 2003. La guerre secrète des OGM. Paris: Seuil.

Kingdon, John W. 1984. Agendas, Alternatives, and Public Policies. New York et al.: Longman.

Klintman, Mikael. 2002. "The Genetically Modified (GM) Food Labelling Controversy: Ideological and Epistemic Crossovers" Social Studies of Science Vol. 32 No. 1 (Feb.): 71-92.

König, Ariane. 2002. "Negotiating the precautionary principle: regulatory and institutional roots of divergent US and EU positions" International Journal of Biotechnology Vol. 4 No. 1: 61-80.

Krimsky, Sheldon. 1982. Genetic Alchemy: The Social History of the Recombinant DNA Controversy. Cambridge, MA and London: MIT Press.

Krimsky, Sheldon. 1991. Biotechnics and Society. The Rise of Industrial Genetics. New York et al.: Praeger.

Krimsky, Sheldon. 2000. "Risk assessment and regulation of bioengineered food products" International Journal of Biotechnology Vol. 2, Nos. 1/2/3: 231-238.

Krimsky, Sheldon / Murphy, Nora. 2001. "Science-based Policy in the Controversy over Genetically Modified Foods" Final Report submitted to Environmental Defense, Medford, MA: Tufts University. 
Kuhn, Thomas S. 1996 [1962]. The Structure of Scientific Revolutions. Chicago: University of Chicago Press.

Kumar, Manoj. 2004 (Sept.). "Genetic Engineering and Biotech Risks: An Insurer's Perspective" Insurance Chronicle. Special issue.

La Rosa-Ames, Lucia. 2003. The European Union's Laws on Genetically Modified Foods - Issues of Consistency with World Trade Organization Rules. LL. M. Thesis. Harvard University (Harvard Law School).

Lambrecht, Bill. 2001. Dinner at the New Gene Café: How Genetic Engineering is Changing What We Eat, How We Live, and the Global Politics of Food. New York: Thomas Dunne Books/St. Martin's Griffin.

Landfried, Christine. 1998. "Kommunikatives Wissen: Überlegungen am Beispiel der europäischen Gentechnikpolitik" in Jann, Werner / König, Klaus / Landfried, Christine / /Wordelmann, Peter (eds.), Politik und Verwaltung auf dem Weg in die transindustrielle Gesellschaft: Festschrift für Carl Böhret zum 65. Geburtstag. Baden-Baden: Nomos: 615-629.

Larson, Alan. Under Secretary of State. 2000 (12 October). "Making Good on Biotechnology's Global Potential” World Food Prize Speech, Des Moines, Iowa. www.biotech-info.net/making_good.html.

Laswell, Harold. D. 1951. "The Policy Orientation” in Lerner, D / Laswell, Harold (eds). The Policy Sciences. Stanford: Stanford University: 3-15.

Laswell, Harold D. 1956. The Decision Process. College Park, MA: University of Maryland Press.

Latour, Bruno (1987) Science in action: How to follow scientists and engineers through society. Cambridge, Mass. and London: Harvard University Press.

Lester, James P. / Stewart, Joseph Jr. 1996. Public Policy: An Evolutionary Approach. Minneapolis et al.: West Publishing Company.

Levi-Faur, David. 2005 (March). "The Global Diffusion of Regulatory Capitalism" The Annals of the American Academy of Political and Social Science Vol. 598: 12-32.

Levidow, Les. 1999a. “La démocratie ‘biotechnologisée'?” Biofutur No. 192 (Sept.): 33-35.

Levidow, Les. 1999b. "Regulating Bt Maize in the United States and Europe" Environment Vol. 41 No. 10: 10-22.

Levidow, Les / Carr, Susan / von Schomberg, Rene / Wield, David. 1996. "Regulating agricultural biotechnology in Europe: harmonization difficulties, opportunities, dilemmas" Science and Public Policy Vol. 23 No. 3 (June): 135157.

Levidow, Les / Carr, Susan / Wield, David / von Schomberg, Rene. 1997. "European Biotechnology Regulation: Framing the Risk Assessment of a Herbicide-Tolerant Crop" Science, Technology and Human Values Vol. 22 No. 4 (Autumn): 472-505.

Levidow, Les / Carr, Susan Carr / Wield, Dave. 1999a. Safety Regulation of Transgenic Crops (SRTC): Completing the Internal Market? A study of the Implementation of EC Directive 90/220. A ten-country study funded by DGXII under its Biotechnology Programme. 
Levidow, Les / Carr, Susan / Wield, David. 1999b. "EU-Level Report" in Safety Regulation of Transgenic Crops (SRTC): Completing the Internal Market? A study of the Implementation of EC Directive 90/220. A ten-country study funded by DGXII under its Biotechnology Programme.

Levidow, Les / Carr, Susan / Wield, David. 2000. "Genetically modified crops in the European Union: regulatory conflicts as precautionary opportunities" Journal of Risk Research Vol. 3 No. 3: 189-207.

Levidow, Les / Carr, Susan / Wield, David. 2005. "European Union regulation of agri-biotechnology: precautionary links between science, expertise and policy" Science and Public Policy Vol. 32 No. 4 (Aug.): 261-276.

Levidow, Les / Murphy, Joseph. 2002. "The Decline of Substantial Equivalence: how civil society demoted a risky concept" Paper for conference at Institute of Development Studies 'Science and citizenship in a global context: challenges from new technologies', 12-13 December 2002.

Lijphart, Arend. 1975. "The Comparable-Cases Strategy in Comparative Research" Comparative Political Studies Vol. 8 No 2 (July): 158-177.

Löfstedt, Ragnar E. / Vogel, David. 2001. "The Changing Character of Regulation: A Comparison of Europe and the United States" Risk Analysis 21(3): 399-416.

Lowi, Theodore J. 1964 “American Business, Public Policy, Case-Studies and Political Theory" World Politics Vol. 16 No. 4: 677-715.

Lowi, Theodore J. 1972 (July/Aug.). "Four Systems of Policy, Politics, and Choice" Administration Review 32: 298-310.

Mackie, Tom / Marsch, David. 1995. "The Comparative Method" in Marsh, David / Stoker, Gerry (eds.). 1995. Theory and Methods in Political Science. London: Macmillan Press: 173-188.

Madsen, Kathrine Hauge / Lassen, Jesper / Sandøe, Peter. 2003. „Genetically modified crops: a US farmer's versus an EU citizen's point of view" Acta Agriculturae Scandinavica Vol. 53, Supplement 1, December: 60 - 67.

Mahoney, James. 2001. The Legacies of Liberalism. Path Dependence and Political Regimes in Central America. Baltimore / London: The Johns Hopkins University Press.

Mahoney, James / Rueschemeyer, Dietrich (eds). 2003a. Comparative Historical Analysis in the Social Sciences. Cambridge, UK: Cambridge University Press.

Mahoney, James / Rueschemeyer, Dietrich. 2003b. "Comparative Historical Analysis: Achievements and Agendas" in Mahoney, James / Rueschemeyer, Dietrich (eds). 2003. Comparative Historical Analysis in the Social Sciences. Cambridge, UK: Cambridge University Press: 3-38.

Maine Legislature. 2003 (13 June). Labeling GM Foods (HP 1149).

Majone, Giandomenico (ed.). 1994a. Regulating Europe. London/New York: Routledge.

Majone, Giandomenico (ed.). 1994b. "The Rise of the Regulatory State in Europe" West European Politics. Vol. 17(3): 77-101. 
Marchant, Gary E. 2002. "Biotechnology and the precautionary principle: right question, wrong answer" International Journal of Biotechnology Vol. 4 No. 1: 34-45.

Martineau, Belinda. 2001. The Creation of the Flavr Savr Tomato and the Birth of Biotech food. London: McGraw Hill.

McKelvey, Maureen / Rickne, Annika / Laage-Hellman, Jens (eds). 2004. The Economic Dynamics of Modern Biotechnology. Cheltenham: Edward Elgar.

Meins, Erika. 2003. Politics and Public Outrage. Explaining Transatlantic and Intra-European Diversity of Regulations on Food Irradiation and Genetically Modified Food. Münster / Hamburg / London: Lit Verlag.

Merton, Robert K. 1968 [1949]. Social Theory and Social Structure. New York / London: The Free Press / Macmillan Publishers.

Merton, Robert K. 1973 [1942]. "The Normative Structure of Science" in R.K. Merton. The Sociology of Science: Theoretical and Empirical Investigations. Chicago: University of Chicago Press: 267-278.

Merriam, Sharan B. 1998. Qualitative Research and Case Study Applications in Education. San Francisco, CA: Jossey-Bass Publishers.San Francisco, CA: Jossey-Bass Publishers.

Meuser, Michael / Nagel, Ulrike 1991. „Experteninterviews - vielfach erprobt, wenig bedacht" in Garz, D. / Kraimer, K. (ed). Qualitativ-empirische Sozialforschung. Konzepte, Methoden, Analysen. Opladen: Westdeutscher Verlag: 441-471.

Miller, Henry I. / Conko, Gregory. 2004. The Frankenfood Myth. How Protest and Politics Threaten the Biotech Revolution. Westport, CT / London: Praeger.

Montpetit, Éric / Rothmayr, Christine / Varone, Frédéric (eds.) (forthcoming). The Politics of Biotechnology: A Cross-Country Comparison of Biomedicine and GM-Food. Lanham, MD: Lexington Books.

Morris, Julian. 2002. "The precautionary principle and biotechnology" International Journal of Biotechnology Vol. 4 No. 1: 46-60.

Müller-Rommel, Ferdinand. 1989. "Green Parties and Alternative Lists Under Cross-National Perspective" in Müller-Rommel, Ferdinand (ed.). New Politics in Western Europe: The Rise and Success of Green Parties and Alternative Lists. Boulder / San Francisco / London: Westview Press: 5-19.

Myhr, Anne Ingeborg / Traavik, Terje. 2002. "The precautionary principle: scientific uncertainty and omitted research in the context of GMO use and release" Journal of Agricultural and Environmental Ethics Vol. 15: 73-86.

National Family Farm Coalition. Farmers' Declaration on Genetic Engineering in Agriculture. www.nffc.net/resources/statements/declare.html.

National Family Farm Coalition. Farmer to Farmer Campaign on Genetic Engineering. www.nffc.net/issues/geissues.html.

National Institutes of Health. 1976 (23 June). Guidelines for research involving recombinant DNA molecules Federal Register Vol. 41 No. 131: 27911-27943.

National Institutes of Health. 1978 (28 July). Recombinant DNA Research. Proposed Revised Guidelines. Federal Register. Reproduced in Watson, James 
D. / Tooze, John. 1981. The DNA Story: A Documentary History of Gene Cloning. San Francisco: W.H. Freeman and Company.

Nollert, Michael. 2000. "Biotechnology in the European Union: a case study of political entrepreneurship" in Bornschier, Volker (ed.). Statebuilding in Europe. The revitalization of Western European Integration. Cambridge, UK: Cambridge University Press.

Norman, Colin. 1976 (1 July). “Genetic manipulation: guidelines issues” Nature 262:2. Reprinted in Watson, James D. / Tooze, John. 1981. The DNA Story: A Documentary History of Gene Cloning. San Francisco: W.H. Freeman and Company.

Nottingham, Stephen. 2003. Eat Your Genes: How Genetically Engineered Food is Entering our Diet. $2^{\text {nd }}$ edition. London/New York: Zed Books.

Nowotny, Helga / Scott, Peter / Gibbons, Michael. 2001. Re-Thinking Science: Knowledge and the Public in an Age of Uncertainty. Cambridge, UK: Polity.

Nuffield Council on Bioethics. 1999 (May). Genetically modified Crops: the ethical and social issues. London: Nuffield Council on Bioethics.

“OGM: la contamination”. 2002 (Jan.). 60 Millions de Consommateurs. No. 357.

Office of Science and Technology Policy. 1984 (31 Dec.). Proposal for a Coordinated Framework for Regulation of Biotechnology; Notice. Federal Register Vol. 49 No. 252: 50856-50673.

Office of Science and Technology Policy. 1986 (26 June). Coordinated Framework for Regulation of Biotechnology; Announcement of Policy and Notice for Public Comment. Federal Register Vol. 51 No. 123: 23302-23350.

Office of Science and Technology Policy. 1992 (24 Feb.). Exercise of Federal Oversight within Scope of Statutory Authority: Planned Introductions of Biotechnology Products into the Environment. Federal Register Vol. 57. 27 Feb. 1992: 6753-6762.

Organisation for Economic Co-operation and Development. 1986. Recombinant DNA safety considerations: Safety considerations for industrial, agricultural and environmental applications of organisms derived by recombinant FNA techniques ("OECD Blue Book"). Study carried out by an Ad hoc Group of government experts created by the Committee for Scientific and Technology Policy during its $34^{\text {th }}$ Session of $10^{\text {th }}-11^{\text {th }}$ February, 1983.

Organisation for Economic Co-operation and Development. 1993. Safety Evaluation of Foods Derived by Modern Biotechnology: Concepts and Principles. Paris: OECD.

Organisation for Economic Co-operation and Development. BioTrack Product Database. webdomino1.oecd.org/ehs/bioprod.nsf and www2.oecd.org/biotech/.

Ostrom, Elinor. 1990. Governing the Commons: the Evolution of Institutions for Collective Actions. Cambridge, UK: Cambridge University Press.

Ostrom, Elinor. 1999 "Institutional Rational Choice: An Assessment of the Institutional Analysis and Development Framework" in Sabatier, Paul A. (ed.). 1999. Theories of the Policy Process. Boulder: Westview Press: 35-71. 
Paarlberg, Robert L. July 2002. "The Contested Governance of GM Foods: Implications for U.S.-EU Trade and the Developing World" Working Paper Series 02-04, Harvard University, Weatherhead Center for International Affairs.

Patterson, Lee Ann / Josling, Tim. 2002. "Regulating Biotechnology: Comparing EU and US Approaches". May 2002. European Policy Paper No.8. University of Pittsburgh Center for West European Studies.

Parsons, Wayne. 1995. Public Policy: An Introduction to the Theory and Practice of Policy Analysis. Aldershot: Edward Elgar.

Peters, Guy B. 1998. Comparative Politics: Theory and Methods. New York: New York University Press.

Peters, Guy B. 1999. "The Legacy of the Past: Historical Institutionalism" in Peters, Guy B. 1999. Institutional Theory in Political Science. The 'New' Institutionalism. London: Cassell: 63-77.

Pew Initiative on Food and Biotechnology. 2002. Three Years Later: Genetically Engineered Corn and the Monarch Butterfly Controversy. Washington, DC: Pew Initiative on Food and Biotechnology.

Pew Initiative on Food and Biotechnology. 2004a (April). Issues in the Regulation of genetically engineered plants and animals. Washington, DC: Pew Initiative on Food and Biotechnology.

Pew Initiative on Food and Biotechnology. 2004b. Overview and Findings: 2004 Focus Groups and Polls. Washington, DC: Pew Initiative on Food and Biotechnology.

Pew Initiative on Food and Biotechnology. Legislation Tracker 2004. Legislative Activity 2001-2004 Related to Agricultural Biotechnology. http://pewagbiotech.org/resources/factsheets/legislation/index.php.

Pierson, Paul. 1994. Dismantling the Welfare State 'Reagan, Thatcher, and the Politics of Retrenchment. Cambridge, UK: Cambridge University Press.

Pierson, Paul. 2004. Politics in Time. History, Institutions, and Social Analysis. Princeton and Oxford: Princeton University Press.

Piervincenzi, Emilio. 2002 (27 July). "Troppi OGM nascosti negli scaffali” La Repubblica.

Pollack, Mark A./ Shaffer, Gregory C. (forthcoming). "Regulating Between National Fears and Global Disciplines: Agricultural Biotechnology in the EU" in Wallace, Helen / Wallace, William / Pollack, Mark A. (eds.) Policy-Making in the European Union. New York: Oxford University Press.

Polanyi, Michael. 1962. "The Republic of Science,” Minerva 1:54-73.

Potter, Clive. 1998. Against the Grain. Agri-Environmental Reform in the United States and the European Union. Oxon / New York: CAB International.

Price, Don K. 1965. The Scientific Estate. Cambridge, MA: Harvard University Press.

Pringle, Peter. 2003. Food, Inc. Mendel to Monsanto - The Promises and Perils of the Biotech Harvest. New York et al.: Simon \& Schuster.

Przeworski, A. / Teune, H. 1970. The Logic of Comparative Social Inquiry. New York: Wiley-Interscience. 
Ragin, Charles. 1987. The Comparative Method: Moving Beyond Qualitative and Quantitative Strategies. Berkeley, CA: University of California Press.

Ragin, Charles. 2000. Fuzzy-Set Social Science. Chicago / London: University of Chicago Press.

Ramjoué, C. 2003. "Comparing Policy Paradigms: Genetically Modified Food Policy in the United States and the European Union" in Nowotny, Helga (ed.). Jahrbuch 2002 des Collegium Helveticum der ETH Zürich. Zürich: Hochschulverlag AG: 53-72.

Reuter, Lars. 2003. Modern biotechnology in postmodern times? A reflection on European policies and human agency. Dordrecht: Kluwer.

Richardson, John B. 2000. "EU Agricultural Policies and Implications for Agrobiotechnology" AgBioForum Vol. 3 No. 2-3: 77-83.

Rihoux, Benoît. 1999. La transformation de l'organisation des partis écologistes en Europe occidentale: contribution à une théorie du changement partisan. Dissertation. Louvain-la-Neuve: Université catholique de Louvain, Département des sciences politiques et sociales.

Rogers, Michael. 1973. Biohazard: How geneticists are creating life forms never before seen on this planet. New York: Avon.

Rogers, Michael. 1975. “The Pandora's Box Congress” Rolling Stone 189 (19 June): 36. Reprinted in Watson, James D. / Tooze, John. 1981. The DNA Story: A Documentary History of Gene Cloning. San Francisco: W.H. Freeman and Company: 28-40.

Rootes, Christopher. 2003. "The Transformation of Environmental Activism: An Introduction" in Rootes, Christopher (ed.). Environmental Protest in Western Europe. Oxford: Oxford University Press: 1-19.

Rose, Richard / Davies, Phillip. 1994. Inheritance in public policy: change without choice in Britain. New Haven and London: Yale University Press.

Rueschemeyer, Dietrich. 2003. „Can One or a Few Cases Yield Theoretical Gains?" in Mahoney, James / Rueschemeyer, Dietrich (eds). 2003. Comparative Historical Analysis in the Social Sciences. Cambridge, UK: Cambridge University Press: 305- 336.

Rücker, Agnes. 2000. Die Entstehung der Novel Food-Verordnung der Europäischen Union. Europäische Hochschulschriften Vol. 409. Frankfurt / Main et al.: Peter Lang.

Rural Advancement Foundation International (RAFI). 2000 (21 Dec.). Speed Bump or Blow-Out for GM Seeds? Stalling Markets, Taco Debacle and Biotech Bail Outs. http://www.etcgroup.org/documents/geno_speedbump.pdf.

Rusanen, Timo / von Wright, Atte / Rusanen, Maria. 2001. "Biotechnology in Finland: transcending tradition" in Gaskell, George / Bauer, Martin W. Biotechnology 1996-2000: the years of controversy. London: Science Museum: 172-180.

Sabatier, Paul A. 1998 "The advocacy coalition framework: revisions and relevance for Europe", Journal of European Public Policy vol. 5 No. 1 (March), 98-130. 
Sabatier, Paul A. (ed.). 1999a. Theories of the Policy Process. Boulder: Westview Press.

Sabatier, Paul A. 1999b. "The Need for Better Theories" in Sabatier, Paul A. (ed.). 1999a. Theories of the Policy Process. Boulder: Westview Press: 3-17.

Sabatier, Paul A. / Jenkins-Smith, Hank C. eds. 1993. Policy Change and Learning. An Advocacy Coalition Approach. Boulder et al.: Westview Press.

Sabatier, Paul A. / Jenkins-Smith, Hank C. 1999. "The Advocacy Coalition Framework: An Assessment" in Sabatier, Paul A. (ed.). 1999. Theories of the Policy Process. Boulder: Westview Press: 117-166.

Sale, Kirkpatrick. 1993. The Green Revolution. The American Environmental Movement 1962-1992. New York: Hill and Wang.

Scharpf, Fritz W. 1997. Games Real Actors Play. Actor-Centered Institutionalism in Policy Research. Boulder, CO: Westview Press.

Schön, Donald A. / Rein, Martin. 1994. Frame Reflection. Toward the Resolution of Intractable Policy Controversies. New York: Basic Books.

Schubert, Klaus. 1991. Politikfeldanalyse: Eine Einführung. Opladen: Leske+Budrich.

Schweizer, Rainer J. 1996. Gentechnikrecht: Zwischenbilanz des Gesetzgebungsprozesses im Gentechnik- und Genschutzbereich. Zurich: Schulthess.

Segarra, Alejandro E. / Rawson, Jean M. 2001 (10 Jan.). "Starlink ${ }^{\mathrm{TM}}$ Corn Controversy: Background" CRS Report for Congress RS20732.

Sheingate, Adam D. 2004. "The Politics of Biotechnology in the United States: Medical and Agricultural Applications Compared" Paper prepared for delivery at the 2004 Annual Meeting of the American Political Science Association, September 2-5.

Shiva, Vandana. 2001. “GMOs: A Miracle?” in Nelson, Gerald C. (ed.). Genetically Modified Organisms in Agriculture. Economics and Politics. San Diego et al.: Academic Press: 191-196.

Single European Act. 1986 (29 June) Official Journal L 169.

Sismondo, Giorgio. 2004. An Introduction to Science and Technology Studies. Oxford: Blackwell Publishing.

Skocpol, Theda. 1995. "Why I am an Historical Institutionalist" Polity Vol.28 No. 1 (fall): 103-106.

Skocpol, Theda. 2003. "Doubly Engaged Social Science. The Promise of Comparative Historical Analysis" in Mahoney, James / Rueschemeyer, Dietrich (eds). Comparative Historical Analysis in the Social Sciences. Cambridge, UK: Cambridge University Press: 407-428.

Skogstad, Grace. 2003. "Legitimacy and / or policy effectiveness?: network governance and GMO regulation in the European Union" Journal of European Public Policy Vol. 10, No. 3 (June): 321-338.

Smith, Jeffrey M. 2003. Seeds of Deception. Exposing Industry and Government Lies About the Safety of the Genetically Modified Foods You're Eating. Fairfield, Iowa: YES! Books. 
Smyth, Stuart / Phillips, Peter W.B. / Kerr, William / Khachatourians, George G. 2004. Regulating the Liabilities of Agricultural Biotechnology. Wallingford / Cambridge, MA: CABI Publishing.

Steinmo, Sven / Thelen, Kathleen / Longstreth, Frank (eds.). 1992. Structuring politics. Historical institutionalism in comparative analysis. Cambridge, UK: Cambridge University Press.

Strasser, Bruno J. 2003. "The transformation of the biological sciences in postwar Europe: EMBO and the early days of European molecular biology research" EMBO reports Vol. 4 No. 6: 540-543.

Strasser, Bruno J. 2002. "Institutionalizing molecular biology in post-war Europe: a comparative study" Studies in History and Philosophy of Biological and Biomedical Sciences. Vol. 33: 533-564.

Sunstein, Cass S. October 2004. "Precautions Against What? The Availability Heuristic and Cross-Cultural Risk Perceptions". Working Paper 04-22. AEIBrookings Joint Center for Regulatory Studies.

Sundlof, Stephen. 2000. "The Role of Science in Regulation and DecisionMaking" AgBioForum Vol. 3 No. 2-3: 137-140.

Surel, Yves. 2000. "The role of cognitive and normative frames in policymaking” Journal of European Public Policy vol. 7 No. 4 (Oct.): 495-512.

Teitelman, Robert. 1989. Gene Dreams. Wall Street, Academia, and the Rise of Biotechnology. New York: Basic Books.

Thelen, Kathleen. 2004. How Institutions Evolve. The Political Economy of Skills in Germany, Britain, the United States, and Japan. Cambridge: Cambridge University Press.

Thelen, Kathleen / Steinmo, Sven. 1992. "Historical institutionalism in comparative politics" in Steinmo, Sven / Thelen, Kathleen / Longstreth, Frank (eds.). Structuring politics. Historical institutionalism in comparative analysis. Cambridge, UK: Cambridge University Press: 2-32.

Thomas, Kenneth R. 2001 (21 March). "Federalism and the Constitution: Limits on Congressional Power" CRS Report for Congress RL30315.

Toke, Dave. 2004. The Politics of GM food: A comparative study of the UK., USA and $E U$. London/New York: Routledge.

Tooze, John. 1978. "Harmonizing Guidelines: Theory and Practice" in Boyer / Nicosia (eds). Genetic Engineering. Elsevier/North Holland Biomedical Press: 279. Reprinted in: Watson, James D. / Tooze, John. 1981. The DNA Story: A Documentary History of Gene Cloning. San Francisco: W.H. Freeman and Company: 340-343.

Transgen 2005a (6 April). "Spanien: Zuwachs für Bt-Mais" www.transgen.de/gentechnik/pflanzenanbau/187.doku.html.

Transgen. 2005b (18 April) "Ist da Gentechnik drin?" http://www.transgen.de/einkauf/lebensmittel/

Treaty establishing the European Economic Community. 1957. http://www.bmdf.co.uk/rometreaty.pdf 
Treaty establishing the European Community (consolidated text). 2002 (24 Dec.). Official Journal C 325.

Treaty on European Union (consolidated text). 2002 (24 December) Official Journal C 325.

Trewavas, Anthony J. 2002. "GM Food is the Best Option We Have" in Pence, Gregory E. The Ethics of Food. A Reader for the Twenty-First Century. Lanham, Maryland: Rowman and Littlefield Publishers: 148-155.

Tudge, Colin. 2004. So Shall We Reap. What's gone wrong with the world's food - and how to fix it. London: Penguin Books.

Union of Concerned Scientists. About UCS. http://www.ucsusa.org/ucs/about/.

Union of Concerned Scientists. Biotechnology. http://www.ucsusa.org/food_and environment/biotechnology/index.cfm.

Union of Concerned Scientists. How UCS is Unique. http://www.ucsusa.org/ucs/join/page.cfm?pageID=1191.

United Nations General Assembly. 1992. Report of the United Nations Conference on Environment and Development, Rio de Janeiro, 3-14 June 1992 ("Rio Declaration") A/CONF.151/26 (Vol. I).

United States Code. http://www.gpoaccess.gov/uscode/browse.html.

United States Code. Federal Insecticide, Fungicide, and Rodenticide Act (FIFRA). Title 7, Chapter 104, $§ 136$ et seq.

United States Code. Plant Protection Act (PPA). Title 7, Chapter 6, $§ 7701$ et seq.

United States Code. Federal Food, Drug, and Cosmetic Act (FFDCA). Title 21, Chapter 9, $\S 301$ et seq.

US Congress. House of Representatives. 2003a (17 June). Committee on Agriculture, Subcommittee on Conservation, Credit, and Research. Testimony of Stephen Johnson, Assistant Administrator, Office of Prevention, Pesticides, and Toxic Substances, US Environmental Protection Agency.

US Congress. House of Representatives. 2003b. Genetically Engineered Food Safety Act (H.R. 2917). Introduced 25 July 2003.

US Congress. House of Representatives. 2003c. Solutions to World Hunger Act of 2003 H.R. 2920. Introduced 25 July 2003.

US Congress. House of Representatives. 2003d. Genetically Engineered Food Right to Know Act H.R. 2916. Introduced 25 July 2003.

US Congress. Senate. 2000. Genetically Engineered Food Right-to-Know Act. S. 2080. Introduced 22 Feb. 2000.

US Department of Agriculture, Foreign Agricultural Service. Statistics for Bulk, Intermediate, and Consumer Oriented. www.fas.usda.gov/ustrade/.

US Public Interest Research Groups. What isn't the biotech industry telling you? pirg.org/ge/GE.asp?id2=4777\&id3=ge\&.

"US to give hungry Zambia food despite GM spat". 2002 (9 Dec.) Reuters. http://www.gmfoodnews.com/re091202.txt. 
Varone, Frédéric / Rothmayr, Christine / Montpetit, Éric (forthcoming).

"Regulating Biomedicine in Europe and North America. A Qualitative-

Comparative Analysis" European Journal of Political Research.

Vermont Legislature. 2004 (26 April). Act Of The General Assembly 2003-2004. An Act Relating to Genetically Engineered Seed (H.777).

Virginia Tech Information Systems for Biotechnology. Field Test Releases in the U.S. (searchable database of APHIS data) www.isb.vt.edu/cfdocs/fieldtests1.cfm.

Vogel, David. 2001. "Ships Passing in the Night: The Changing Politics of Risk Regulation in Europe and the United States" European University Institute Working Paper RSC No. 2001/16. San Domenico di Fiesole, Italy.

von Schomberg, Rene. 1998. "GMO-release: from risk-based to uncertainty based regulation" in Past, Present and Future Considerations in Risk Assessment when using GMOs Coordination Commission Risk Assessment Research (CCRO) Proceedings Second International Workshop: 125-136.

Wagner Pfeifer, Beatrice. 1997. Das Umweltrecht vor den Herausforderungen der Gentechnologie. Habilitationsschrift. Schriftenreihe zum Umweltrecht, Bd. 13. Zürich: Schulthess.

Watson, James. D. 1968. The Double Helix: A Personal Account of the Discovery of the Structure of DNA. New York: Mentor.

Watson, James D. / Crick, Francis Harry Compton. 1953. "Molecular structure of Nucleic Acids" Nature 171: 737-738.

Watson, James D. / Tooze, John. 1981. The DNA Story: A Documentary History of Gene Cloning. San Francisco: W.H. Freeman and Company.

Watson, James D. et al. 1992. Recombinant DNA. 2nd edition New York: Scientific American Books.

Webster, Andrew. 1991. Science, technology and society: new directions. Houndmills, Basingstoke, Hampshire : Macmillan.

Wegener, Mark / Fitzpatrick, Peter. 2005 (23 May). "Europe Gets Litigious" Legal Times Vol. 28 No. 21.

Weiss, Robert S. 1994. Learning from Strangers. The Art and Method of Qualitative Interview Studies. New York, NY: The Free Press.

White, Louise G. 1994. "Values, Ethics, and Standards in Policy Analysis" in Nagel, Stuart S. (ed.). Encyclopedia of Policy Studies, 2nd edition: 857-878.

White House. 2000 (3 May). "Clinton Administration Agencies Announce Food and Agricultural Biotechnology Initiatives: Strengthening Science-based Regulation and Consumer Access to Information". Press Release. www.cfsan.fda.gov/ /rd/whbio53.html.

Wiener, Jonathan B. / Rogers, Michel D. 2002. "Comparing precaution in the United States and Europe" Journal of Risk Research 5(4): 317-349.

Wildavsky, Aaron. 1987 [1979]. Speaking Truth to Power. The Art and Craft of Policy Analysis. New Brunswick, NJ: Transaction, Inc.

Windsor, Charles (Prince Charles). 1999 (1 June). "Questions about Genetically Modified Organisms" The Daily Mail. 
Winickoff, David / Jasanoff, Sheila / Busch, Lawrence / Grove-White, Robin / Wynne, Brian. 2005. "Adjudicating the GM Food Wars: Science, Risk, and Democracy in World Trade Law" Yale Journal of International Law 30.1 (Winter): 81-123.

Winston, Mark L. 2002. Travels in the Genetically Modified Zone. Cambridge, MA: Harvard University Press.

Wright, Susan. 1994. Molecular Politics: Developing American and British Regulatory Policy for Genetic Engineering, 1972-1982. Chicago and London: University of Chicago Press.

Wright, Susan. 1996. "Molecular Politics in a Global Economy" Politics and the Life Sciences Vol.15 No.2 (Sept): 249-263.

World Trade Organization. 2003 (20 May). European Communities - Measures affecting the Approval and Marketing of Biotech Products. Request for consultation by the United States.

G/AG/GEN/60 G/L/627 G/SPS/GEN/397 G/TBT/D/28 WT/DS291/1.

World Trade Organization. Agreement on the Application of Sanitary and Phytosanitary Measures ("SPS Agreement") http://www.wto.org/english/tratop_e/sps_e/spsagr_e.htm.

World Trade Organization. Agreement on Technical Barriers to Trade ("TBT Agreement”) http://www.wto.org/english/docs_e/legal_e/17-tbt.pdf.

Wynne, Brian. 2001. "Creating Public Alienation: Expert Cultures of Risk and Ethics on GMOs" Science as Culture Vol. 10, No. 4: 445-481.

Young, Alasdair. 2001. "Trading Up of Trading Blows? US Politics and Transatlantic Trade in Genetically Modified Food" EUI Working Paper RSC 2001/30. San Domenico di Fiesole. 


\title{
AUTHOR's CURRICULUM VitAE
}

\author{
Celina Ramjoué
}

Born on 1 November 1974 in Hamburg, Germany

German and United States citizenships

\section{EdUCATION}

University of Zurich, Zurich (Switzerland), 2000-2006

Ph.D. Student, Department of Political Science

2006: provisional Doctor of Philosophy (Ph.D.) diploma; title expected in 2007

Dissertation topic: "The Transatlantic Rift in Genetically Modified Food Policy"

Thesis directors: Prof. D. Kübler (University of Zurich), Prof. F. Varone

(Université de Genève)

European University Institute, San Domenico di Fiesole (Italy) 2004-2005

Visiting Student, Department of Political and Social Sciences

Host professors: Prof. A. Héritier, Prof. R. Stankiewicz

Harvard University, Cambridge, Massachusetts (USA), 2003-2004

Visiting Fellow, John F. Kennedy School of Government, Program on

Science, Technology and Society

Host professor: Prof. S. Jasanoff

Swiss Federal Institute of Technology, Zurich (Switzerland), 2001-2002

Collegiate, Collegium Helveticum (interdisciplinary institute on science, technology and society issues)

Programme director: Prof. H. Nowotny

University of Munich, Munich (Germany), 1992-1998

Master of Arts (M.A.) in Political Science (1998)

Student of political science (major), American studies, and communications (minors)

Masters thesis topic: "Post-Cold War Mediterranean Security Co-operation"

University of Virginia, Charlottesville, Virginia (USA), 1994-1996

Bachelor of Arts (B.A.) in Foreign Affairs (1996) (High Distinction)

Senior thesis topic: "The U.S. Congress, NATO, and the End of the Cold War" 
European Commission, Research Directorate-General, Science in Society Directorate, Brussels (Belgium), since September 2005

Policy and project officer, Governance and Ethics Unit: Focus on issues surrounding access, dissemination and preservation of scientific publications ("open access" debate)

University of Zurich, Dept. of Political Science, Zurich (Switzerland), 2000-2003

Researcher, 2000-2002: Member of research project entitled "Comparative Policy

Research: Explaining Policy Design for Assisted Reproductive Technologies across Countries and Time" (funding: Swiss National Science Foundation)

Teaching Assistant, 2002-2003

Lecturer, summer semester 2003

Forum Europe, Brussels (Belgium), 1999-2000

Company specialized in event organization, public relations and publishing on EU policy issues

Project Manager, 1999: launch of "Friends of Europe" (non-profit organization promoting public debate on European policy issues)

Business Development Manager, 1999-2000

European Commission, Brussels (Belgium), Trainee, 1998-1999 (Bureau of European Policy Advisers, BEPA, former Forward Studies Unit), Commission's think tank

Center for Applied Policy Research, Munich (Germany), Research Assistant, 1997-1998 (Think tank affiliated with the University of Munich)

German Institute for International and Security Affairs, Ebenhausen (Germany), Research Assistant, summer 1997 (Independent think tank advising German institutions, now located in Berlin)

Congressional Research Service, Washington, DC (USA), Research Assistant, autumn 1996 (Research Branch of the United States Congress)

Atlantic Council of the United States, Washington, DC (USA), Intern, summer 1996 (Program on NATO and European security)

\section{SCHOLARSHIPS}

Swiss National Science Foundation Fellowship for Prospective Researchers, financing of research stays at Harvard University (2003-2004) and the European University Institute (2004-2005) 
Swiss National Science Foundation financial support for participation in the Program in Quantitative Methods of Social Research, Ann Arbor, Michigan, summer 2004 and in the Oslo Summer School in Comparative Social Science Studies, summer 2001

Collegium Helveticum Scholarship, Swiss Federal Institute of Technology, 2001-2002

FAWCO Foundation Merit Award, Scholarship of the Federation of American Women's Clubs Overseas, financial support for studies at the University of Virginia, 1994 